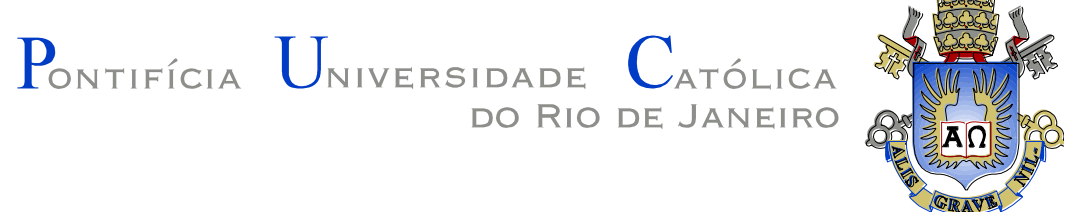

João Fernandes Reinert

\title{
PARÓQUIA E INICIAÇÃO CRISTÃ: UMA RELAÇÃO URGENTE. A interdependência entre renovação paroquial e mistagogia catecumenal.
}

\section{Tese de Doutorado}

Tese apresentada ao Programa de Pós-graduação em teologia da PUC-Rio como requisito parcial para a obtenção de título de Doutor em Teologia.

Orientador: Prof. Mario de França Miranda 


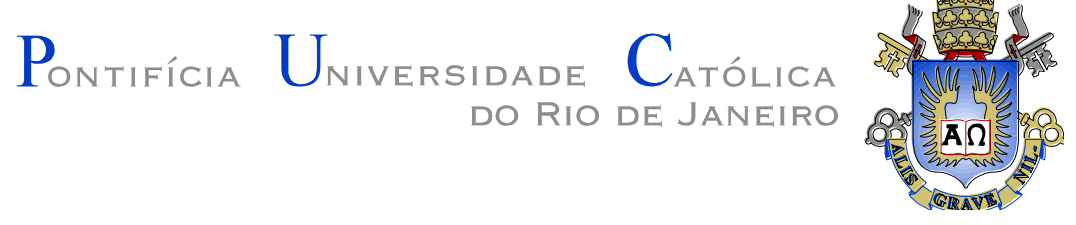

João Fernandes Reinert

\section{PARÓQUIA E INICIAÇÃO CRISTÃ: UMA RELAÇÃO URGENTE. A interdependência entre renovação paroquial e mistagogia catecumenal.}

Tese apresentada como requisito parcial para a obtenção do grau de Doutor pelo Programa de Pós-Graduação em Teologia do Departamento de Teologia do Centro de Teologia e Ciências Humanas da PUC-Rio. Aprovada pela Comissão Examinadora abaixo assinada

Prof. Mario de França Miranda Orientador Departamento de Teologia - PUC-Rio

Prof. Luis Fernando Ribeiro Santana Departamento de Teologia - PUC-Rio

Prof. Joel Portella Amado Departamento de Teologia - PUC-Rio Prof. Gilson José Macedo da Silveira Vicariato Suburbano

Prof. José Ariovaldo da Silva Instituto Teológico Franciscano - Petrópolis

Profa. Denise Berruezo Portinari Coordenadora Setorial de Pós-Graduação e Pesquisa do Centro de Teologia e Ciencias Humanas - PUC-Rio.

Rio de Janeiro, 2 de outubro de 2014 
Todos os direitos reservados. É proibida a reprodução total ou parcial do trabalho sem autorização da universidade, do autor e do orientador.

\section{João Fernandes Reinert}

Graduou-se em Filosofia pelo Instituto de Filosofia S. Boaventura, Campo Largo, PR, em 2001. Graduou-se em Teologia pelo Instituto Teológico Franciscano, Petrópolis, RJ, em 2005. Mestre em teologia sistemático pastoral, pela PUC-Rio, em 2009. Ordenado Sacerdote em 2006, trabalhou como vigário paroquial na paróquia Porciúncula de Santana, em Niterói e paróquia São Francisco de Assis, em Duque de Caxias. Foi pároco da paróquia Nossa Senhora da Boa Viagem, na Rocinha, RJ, e atualmente é pároco na paróquia Santa Clara, Duque de Caxias, RJ. É professor do Instituto Teológico Franciscano, Petrópolis, RJ.

\section{Ficha Catalográfica}

Reinert, João Fernandes

Paróquia e iniciação cristã: uma relação urgente. A interdependência entre renovação paroquial e mistagogia catecumenal / João Fernandes Reinert; orientador: Mario de França Miranda. - 2014.

299 f.; $30 \mathrm{~cm}$

Tese (doutorado)-Pontifícia Universidade Católica do Rio de Janeiro, Departamento de Teologia, 2014.

Inclui bibliografia

1. Teologia - Teses. 2. Pós-modernidade. 3. Iniciação à vida cristã. 4. Catecumenato. 5. Mistagogia. 6. Experiência de Deus. 6. Paróquia. 7. Estrutura eclesial. 8. Renovação. 9. Missão. 10. Comunidade. I. Miranda, Mário de França. II. Pontifícia Universidade Católica do Rio de Janeiro. Departamento de Teologia. III. Título. 


\title{
Agradecimentos
}

\begin{abstract}
À Província da Imaculada Conceição do Brasil, e aos frades da mesma, que muito me motivaram no estudo acadêmico, no amor e zelo pastoral. Minha grande gratidão à Província pela oportunidade de dar continuidade ao trabalho acadêmico.
\end{abstract}

Aos professores do Departamento de Teologia da PUC-Rio, de quem recebi grandes lições e oportunidade de aprofundamento sobre os temas e os desafios teológico-pastorais atuais.

Ao meu orientador, professor Mário de França Miranda, pela sua humildade e humanidade, pelo apoio, confiança e zelo nas conversas e orientações nas várias etapas desta pesquisa. Sua capacidade intelectual conciliada com sua humildade muito nos motiva na busca do conhecimento do Mistério.

Aos confrades de minha última e da atual fraternidade franciscana, dos quais recebi todo apoio e incentivo na dedicação à pesquisa.

Ao Instituto teológico Franciscano, ITF, onde recebi uma sólida base teológica, fundamental para a continuidade do aprofundamento teológico. À biblioteca do ITF, rica nas revistas e obras teológicas. Às bibliotecárias da mesma, de modo especial a Érica, sempre solícitas no atendimento e na ajuda fraterna.

Ao CNPQ, pelo incentivo à pesquisa e apoio financeiro.

A minha família, de quem recebi o tremor pelo Mistério e as primeiras bases de uma teologia viva, orante e celebrativa.

A Deus e seu Espírito, não em último lugar, mas ao contrário, como síntese de todos os agradecimentos supra citados. É ele o suscitador e possibilitador de toda renovação eclesial e pastoral. 


\section{Resumo}

Reinert, João Fernandes; Miranda, Mario de França. Paróquia e iniciação cristã: uma relação urgente. A interdependência entre renovação paroquial e mistagogia catecumenal. Rio de Janeiro, 2014, 299 p. Tese de Doutorado - Departamento de Teologia, Pontifícia Universidade Católica do Rio de Janeiro.

A presente pesquisa é um diálogo entre dois temas fundamentais e, ao mesmo tempo, desafiadores para a agenda pastoral do século XXI: iniciação à vida cristã e instituição paroquial. Iniciar na fé, em tempos do fim do cristianismo sociológico, e atrair para a vida em comunidade, quando cresce a disinstitucionalização religiosa, são tarefas nada fáceis. A Igreja vem se empenhando para responder a tais desafios. Encontrou no catecumenato a grande redescoberta pastoral para iniciar na fé. Trata-se de um caminho privilegiado de transmitir a fé, de amadurecê-la e fazê-la progredir. A pedagogia catecumenal possui características fundamentais para o amadurecimento do ser cristão, tais como a progressividade da fé, o casamento catequese-liturgia, forte densidade mistagógica e experiencial da fé, entre outras. Contudo, o catecumenato depende de renovadas estruturas eclesiais, e aqui chegamos ao paroquial, cujo cansaço institucional não vem de hoje, assim como não são de hoje as tentativas de renovação. Nossa pesquisa mostra que fundamental é perceber que iniciação cristã catecumenal e renovação paroquial não são dois temas distantes, por isso mesmo devem ser pensados conjuntamente, na certeza de que o futuro de um depende da vitalidade do outro, e vice-versa. Há entre eles uma relação muito próxima, uma feliz dependência, a qual chamamos relação dialética. A dinâmica catecumenal é fundamental não somente para a iniciação cristã, mas questiona, provoca, ilumina a conversão paroquial, e esta, à medida que se renova é decisiva para a consolidação e prática catecumenal. Portanto, trata-se de um processo relacional, de iluminação mútua. Entre novo modelo de paróquia, e consolidação da prática catecumenal, o futuro de um depende da vitalidade do outro.

\section{Palavras-chave}

Pós-modernidade; iniciação à vida cristã; catecumenato; mistagogia, experiência de Deus; paróquia; estrutura eclesial; renovação; missão; comunidade. 


\section{Abstract}

Reinert, João Fernandes; Miranda, Mario de França (Advisor). Parish and Christian initiation: an urgent relationship. The interdependence between parish renewal and catechumen mystagogy. Rio de Janeiro, 2014, 299 p. Doctoral Thesis - Departamento de Teologia, Pontifícia Universidade Católica do Rio de Janeiro.

This present research is a dialogue between two fundamental themes and at the same time challenging for the pastoral agenda of the XXI century: initiation into Christian life and parochial institution. Initiate faith, in the end times of sociological Christianity, and to attract community life, when growing religious disinstitutionalization, are not easy tasks. The Church has been committed to respond to these challenges. In the catechumenate, is found the great pastoral rediscovery of faith initiation. It treats a privileged way to transmit faith, ripen it and make it progress. The catechumenal pedagogy has fundamental characteristics for the maturity of the Christian being, such as the progressing of faith, the marriage catechesis- liturgy, strong mystagogic density and experiential of faith, among others. However, the catechumenate depends on renewed ecclesial structures, and here we come to the parochial level, whose institutional fatigue does not come today, as they are not today's attempts of renewals. Our research shows that fundamentally, it is seem that, the Christian Initiation catechumenal and the parochial renewal are not two distinct themes, therefore, should be thought of together, in the certainty that the future of one depends on the vitality of the other, and vice versa. There is a very close relationship between them, a happy dependency, which we call dialectical relationship. The catechumenal dynamical is essential not only for the Christian initiation, but questions, provokes, enlightens parochial conversion, and this , as it renews itself, is decisive for the consolidation and catechumenal practice. Therefore, it treats a relational process of mutual illumination. Among new model of parochial, and consolidating catechumenal practice, the future of one depends on the vitality of the other.

\section{Keywords}

Initiation into Christian life; catechumenate; mistagogy; experience; parochial; ecclesial structure; renewal; mission; community. 


\section{Sumário}

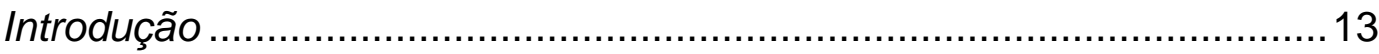

1.FÉ CRISTÃ E A ATUAL CONJUNTURA SÓCIO CULTURALRELIGIOSA: O CONTEXTO EM QUE SE REALIZAM A INICIAÇÃO À

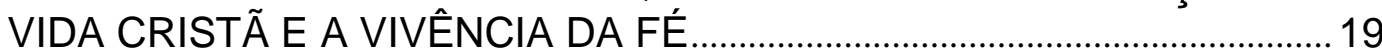

1.1_Mais do que época de mudança, mudança de época .......................19

1.2_Crise do paradigma moderno racionalista e a emergência de uma nova sensibilidade sócio cultural .................................................... 21

1.3_Principais características do atual paradigma cultural......................24

1.3.1_O pluralismo cultural e religioso ............................................24

1.3.2_Declínio do institucional e centralidade do indivíduo ......................28

1.3.3_O fenômeno da globalização ........................................................31

1.3.4_A afirmação do urbano: uma nova configuração do tempo e do

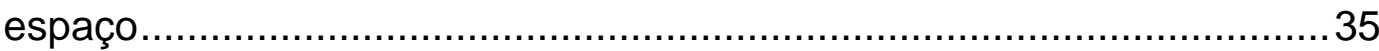

1.4_Mudança de época e as transformações religiosas ........................37

1.4.1_Uma religiosidade inédita ....................................................... 37

1.4.2_Privatização das crenças e a crise das instituições religiosas.........39

1.4.3_Mobilidade religiosa........................................................... 41

1.4.4_Crise da transmissão religiosa e o imperativo da escolha...............43

1.5Crise do cristianismo ou possibilidade de uma nova configuração? ...45

1.5.1_A fé cristã e os desafios da mudança de época: um olhar teológico

1.5.2_Cristianismo e mudança de época: uma ruptura que exige novas posturas

\section{INICIAÇÃO À VIDA CRISTÃ: IDENTIDADE, TEOLOGIA E}

PASTORAL

2.1_Da passagem da catequese tradicional ao renovado compromisso com a iniciação à vida cristã....................................................... 51

2.2_Os primeiros passos do novo paradigma de iniciação cristã.............54

2.2.1_Distinção e aproximação dos conceitos ......................................58

2.2.2_Os adultos como principais interlocutores da iniciação à vida cristã

2.3_Iniciação à vida cristã: participação no mistério de Cristo .................64

2.4_A centralidade da experiência de Deus na iniciação à vida cristã .....68

2.4.1_Experiência, termo de difícil compreensão...................................69

2.4.2_Experiência religiosa e experiência de Deus ..................................71

2.4.3_Experiência cristã de Deus.......................................................74

2.5_Iniciação à vida cristã: dialética entre a graça divina e a resposta humana ..................................................................................... 77 
2.5.1_A primazia da iniciativa de Deus: revelação como condição para

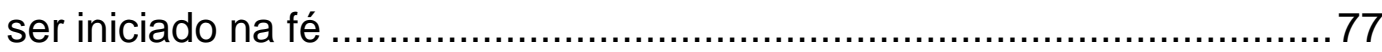

2.5.2_Fé-conversão: resposta humana à revelação ............................... 80

3. O CATECUMENATO ONTEM E HOJE: A REDESCOBERTA DE UM CAMINHO PRIVILEGIADO DE INICIAÇÃO À VIDA CRISTÃ ..................83

3.1_Origem e desenvolvimento do catecumenato ...................................... 84

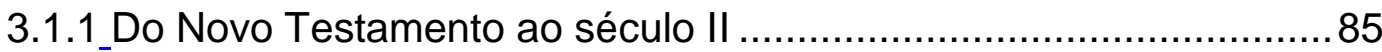

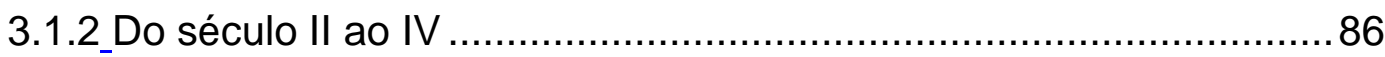

1.3_Tradição apostólica de Hipólito de Roma ..........................................89

3.1.4_A decadência do catecumenato: da adesão pessoal à fé ao

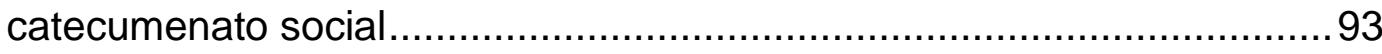

3.2_A restauração do catecumenato e o Ritual de Iniciação Cristã de

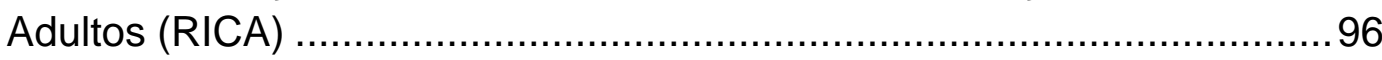

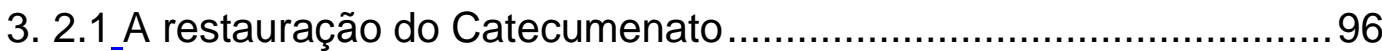

3.2.2_Ritual de Iniciação Cristã de Adultos (RICA) ................................. 98

3.2.3_Destinatários do catecumenato e as diversas formas de percorrer o caminho catecumenal ...................................................... 100

3.3_Elementos eclesiológicos e pastorais da pedagogia catecumenal...102

3.3.1_A progressividade da iniciação à vida cristã.................................102

3.3.2_Catecumenato e a comunidade eclesial...................................... 105

3.3.2.1_A centralidade da comunidade no processo de iniciação cristã . 105 3.3.2.2_A dimensão comunitária no Ritual de Iniciação Cristã de

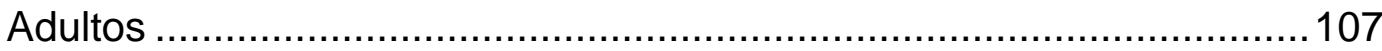

3.3.2.3_A comunidade eclesial é também catecúmena ..........................109

3.4_O envolvimento da comunidade na iniciação à vida cristã ................111

3.5_A estrutura do itinerário catecumenal .............................................. 115

3.5.1_Pré-catecumenato: um tempo de descoberta...............................116

3. 5.1.1_Pré-catecumenato e o anúncio kerigmático ..............................117

3.5.1.2_Pré-catecumenato e acolhida ................................................118

3.5.2_Catecumenato: a segunda etapa do processo da iniciação .......... 122

3.5.2.1_Catequese e liturgia, um casamento necessário na iniciação

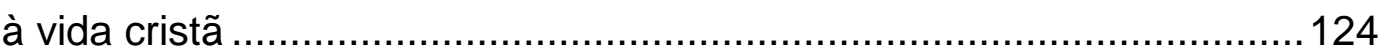

3.5.2.2_A integração catequese-liturgia no Ritual de Iniciação Cristã

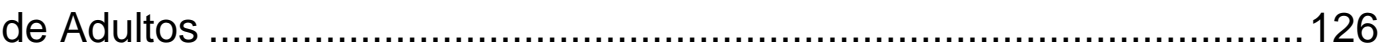

3.5.2.3_Centralidade do ano litúrgico e a variedade de símbolos e

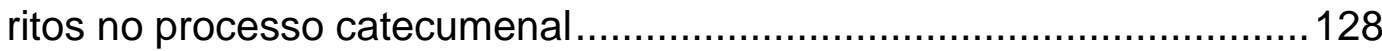

3.6_O tempo da purificação/ iluminação ................................................ 133

3.6.1_Unidade dos sacramentos da iniciação cristã e o caráter pascal

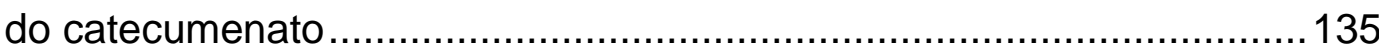

3.6.2_A prática do batismo de crianças diante da unidade sacramental. 136

3.7_Mistagogia: aprofundar a graça sacramental ................................139

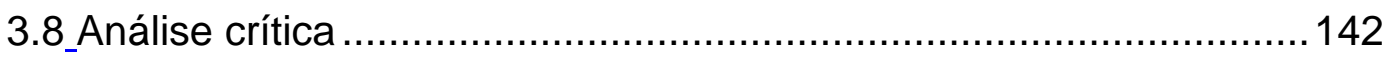


4. A INSTITUIÇÃO PAROQUIAL ……………………………………………......147

4.1_Origem e desenvolvimento da paróquia .......................................148

4.1.1_Antes do nascimento da paróquia: a Igreja das casas ..................149

4.1.2_Títuli

4.1.2_Da Igreja das casas à estruturação da paróquia ...........................156

4.2_A paróquia entre a desconfiança e a credibilidade ...........................160

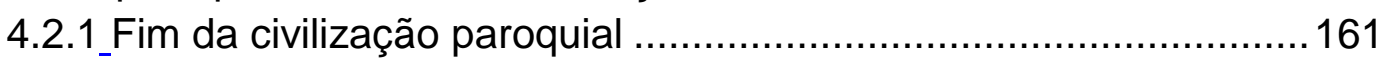

4.2.2_Paróquia: uma instituição de massa............................................164

4.2.3Paróquia: uma instituição territorial ............................................168

4.2.4_Agência de prestação de serviço religioso ………........................170

4.3_Teologia, identidade e missão da paróquia ......................................172

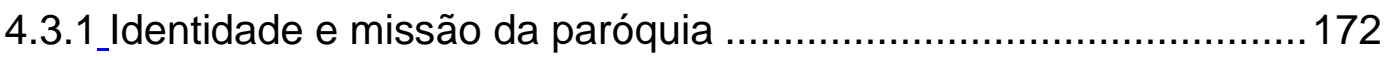

4.3.2.Paróquia, um conceito simbólico instrumental ............................. 177

4.4_A pertinência da paróquia na vida da Igreja ....................................179

4.5_Da crise a novas possibilidades: a urgência de renovação

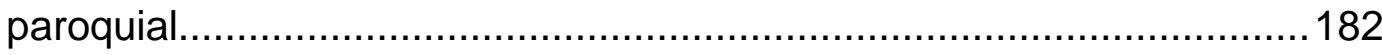

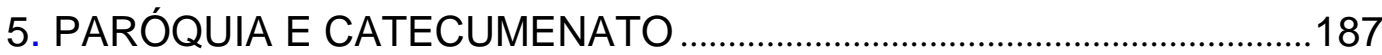

5.1_Iniciação cristã catecumenal e instituição paroquial: em busca da unidade de fundo

5.1.2_Relação dialética: renovação paroquial e efetiva prática catecumanal

5.2_Do primeiro anúncio a uma estrutura paroquial missionária:

interpelações mútuas entre pré-catecumenato e a missionariedade

paroquial.

5.2.1_A missionariedade paroquial à luz da dinâmica pré-catecumenal.194

5.2.2_Otimizar na paróquias as oportunidades já existentes para o primeiro e segundo anúncios ...........................................................199

5.2.2_A (re) descoberta de novos espaços de anúncio ..........................202

5.2.4_O acompanhamento pessoal do pré-catecumenato e a acolhida

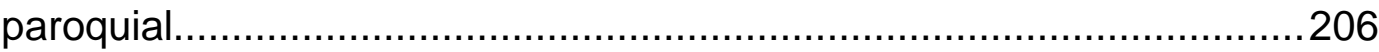

5.3_O desafio de superar as estruturas obsoletas que não favorecem

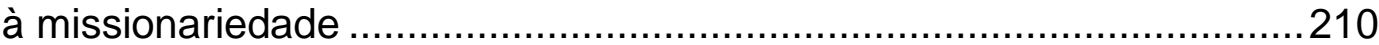

5.3.1_Uma nova relação com o território ............................................213

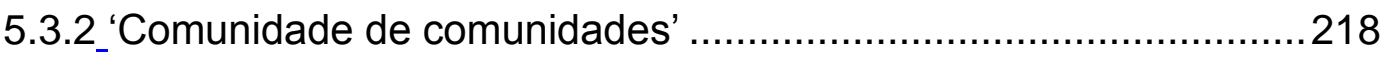

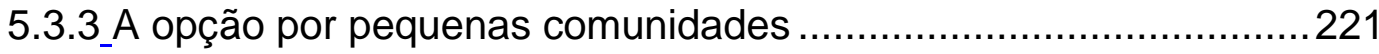

5.3.4_A contribuição das Comunidades Eclesiais de Base......................225

5.4_A segunda etapa do processo catecumenal e o 'catecumenato permanente': a formação permanente a serviço da renovação

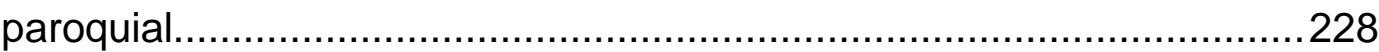

5.4.1_A inteligibilidade da fé na iniciação à vida cristã...........................229 
5.4.2_A necessária relação entre formação inicial e formação permanente na renovação paroquial à luz do período catecumenal ......230 5.4.3_O lugar da formação permanente na renovação paroquial ............232 5.4.3.1_Formar-se para formar: o desafio da formação inicial e

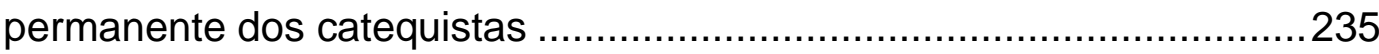

5.4.3.2_A formação inicial dos seminaristas e a formação permanente

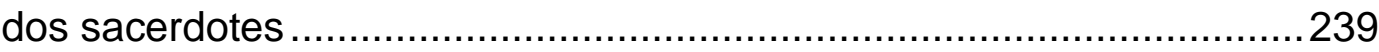

5.4.4_Da ministerialidade do catecumenato a uma paróquia toda

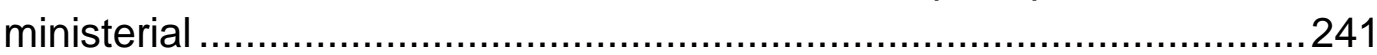

5.4.4.1 A ministerialidade do catecumenato.........................................2 242

5.4.4.2_A estrutura ministerial da paróquia questionada ........................2. 246

5.3.4.3_A necessária passagem do binômio 'clero-leigo' para 'comunidade-carismas e ministérios'....................................................247

5.4.4.4_Laicato: 'ajuda' ou corresponsabilidade? .................................250

5.4.4.5_Antes de novos ministérios, um ministério novo: repensando o modelosacerdotal cultual em prol da figura ministerial do presbítero.....252

5.4.4.6_Presbítero, homem de comunhão eclesial ...............................256

5.4.5_Novos ministérios e uma paróquia toda ministerial .......................260

5.5_As etapas da iluminação/purificação e mistagogia e a conversão

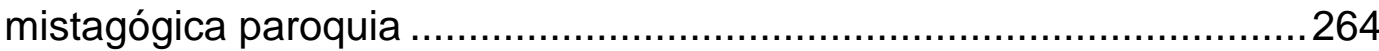

5.5.1_Mistagogia e experiência............................................................265

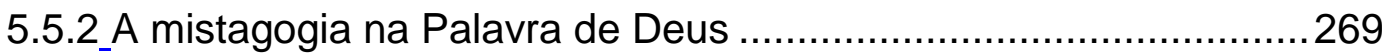

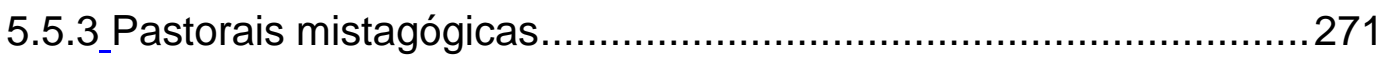

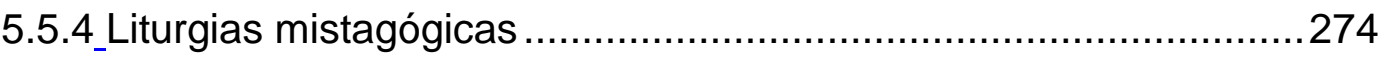

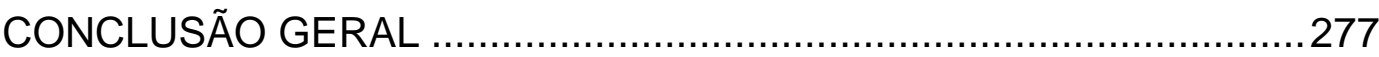

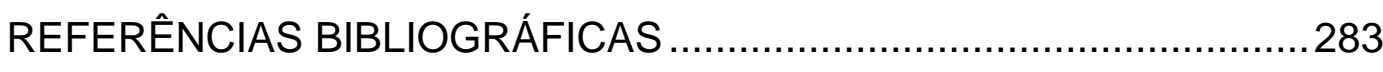




\section{Siglas}

AA Decreto Apostolicam Actuositatem, do Concílio Vaticano II

AG Decreto Ad Gentes, do Concílio Vaticano II

CEBs Comunidades Eclesiais de Base

CD Decreto Christus Dominus, do Concílio Vaticano II

CDC Código de Direito Canônico

CL Christifideles Laici (Sobre os Leigos, João Paulo II, 1988

CELAM Conselho Episcopal Latino-Americano

CERIS Centro de Estatística Religiosa e Investigações Sociais

CIC Catecismo da Igreja Católica

CNBB Conferência Nacional dos Bispos do Brasil

CR Catequese Renovada (CNBB, 1983

CT Catechei Tradendae (Catequese Hoje, João Paulo II, 1978)

DAp Documento de Aparecida

DCG Diretório Catequético Geral

DGC Diretório Geral para a Catequese

DGAE Diretrizes Gerais da Ação Evangelizadora da Igreja no Brasil

DSD Documento de Santo Domingo

DD Carta Apostólica Dies Domini, sobre a santificação do Domingo

DV Constituição Dogmática Dei Verbum, do Concílio Vaticano II

EA Exortação Apostólica pós-sinodal Ecclesia in América

EG Evangelii Gaudium

EM Evangelii Nuntiandi (Anúncio Evangélico, Paulo VI, 1975)

FC Exortação Apostólica Familiaris Consortio

GS Gaudium et Spes (A Igreja no mundo atual, 1965)

IBGE Instituto Brasileiro de Geografia e Estatística

LG Constituição Dogmática Lumen Gentium, do Concílio Vaticano II

Medellín Conclusões de Medellín

NMI Carta Apostólica Novo Milennio Ineunte

Puebla Documento de Puebla

PDV Pastores dabo vobis

PO Presbyterorum Ordinis (Ministério e vida dos presbíteros, 1965) 
RICA Rito de Iniciação Cristã de Adultos (Ritual Romano, 1973)

REB Revista Eclesiástica Brasileira

RM Redemptoris Missio (Sobre a Missão, João Paulo II, 1965)

SC Constituição sobre a Sagrada Liturgia Sacrosanctum Concilium

UR Unitatis Redintegratio (Sobre o Ecumenismo, 1965)

$1^{\text {a }} \mathrm{SBC} \quad 1^{\text {a }}$ Semana Brasileira de Catequese (1986)

$2^{\circ} \mathrm{SBC} \quad 2^{\text {a }}$ Semana Brasileira de Catequese (2001)

PDV Pastoris Dabo Vobis 


\section{Introdução}

Fala-se atualmente sem parcimônia em mudança de época no intuito de expressar a radicalidade das transformações socioculturais e religiosas das últimas décadas, da quais ninguém está isento. Pessoas, culturas, instituições, tradições, cidade e o campo, apenas para mencionar as principais instâncias sociais, são atingidas pelo novo cenário que se impõe sem pedir licença. Nem mesmo a religião consegue estar imune às reviravoltas em percurso. Numa época marcada pelo efêmero, pelo subjetivo, pelo relativo, pela desistitucionalização parece natural que a adesão religiosa se apresente vulnerável e instável, haja vista o alto índice de trânsito religioso no mapa da religiosidade contemporânea. Resulta disso a afirmação de que a transmissão da fé constitui um dos maiores desafios pastorais da atualidade, sobretudo se assumirmos a fé como experiência fundante que gera encontro, conversão, sentido existencial, projeto de vida.

Refletir sobre os desafios e as possibilidades da transmissão da fé é premente, serviço este que nem a teologia nem a pastoral podem se dar ao direito de se esquivarem. Os últimos acontecimentos eclesiais como muita propriedade têm chamado a atenção para tal cenário e convocando todos os cristãos a uma postura essencialmente missionária. A quinta conferência episcopal latino americana e caribenha, realizada em Aparecida, SP, ganha destaque neste particular. É patente neste documento a preocupação com a transmissão da fé. O Sínodo dos bispos de 2012, realizado em Roma, sobre a Nova Evangelização, situa-se igualmente neste horizonte pastoral. Nova evangelização, como o nome sugere, remete a novo vigor pastoral com renovado modo de comunicar a boa nova num contexto que também é novo.

Atentos a esta realidade, a presente pesquisa intitulada "Paróquia e iniciação cristã: Uma relação urgente. A interdependência entre renovação paroquial e mistagogia catecumenal' tem como objetivo olhar de perto o atual cenário da iniciação cristã, sobretudo no mundo dos jovens e adultos, onde o desafio é ainda maior. Contudo, concomitante a este objetivo acrescenta-se um outro, não menos importante: a configuração eclesial onde se vive a fé na qual se foi iniciado, não como dois temas dispares, mas momentos inseparáveis de um 
único processo. Em outros termos, é também nosso desejo perguntar pela realidade das estruturas eclesiais da vivência da fé, ora transmitida e nela iniciada.

Posto isto, cabe agora ir do genérico ao particular: Expliquemo-nos. Da preocupação com a transmissão da fé/ iniciação cristã nas suas mais diversas modalidades e expressões nos debruçaremos sobre um modo privilegiado de realizar tal missão, patrimônio da história da Igreja, esquecida ao longo da história, e recuperada no contexto do aggiornamento eclesial promovido pelo Vaticano II: o catecumenato. O catecumenato foi uma das mais bem sucedidas instituições da iniciação cristã, datada dos primeiros séculos do cristianismo e resgatada nas últimas décadas para responder, com as devidas adaptações, aos atuais desafios da transmissão da fé. No tocante ao segundo objetivo, a estrutura eclesial para a transmissão e vivência da fé, nos interessará sobremaneira a estrutura paroquial, a qual se encontra há algum tempo em busca de renovação. Concordamos com sua pertinência para a missão evangelizadora da Igreja. Tratase de uma instituição que não pode sem mais ser descartada, pois carrega consigo uma densidade real e simbólica inquestionável para a vivência da fé. Contudo, para conservar tal pertinência e significabilidade é urgente uma profunda renovação estrutural.

Nascida no século quarto, praticamente imutável até os dias de hoje, ela encontra-se em profunda crise. Dentre inúmeros questionamentos feitos a ela, encontra-se a pergunta: é ela lugar da iniciação cristã e cultivo da fé dos já iniciados? Ou ainda, é ela a melhor configuração eclesial para a implantação da iniciação cristã catecumenal? Se a resposta for negativa, estaria o catecumenato condenado ao fracasso, por falta de estrutura eclesial correspondente a sua grandeza? Somente o retorno do catecumanto garante por si uma renovada iniciação cristã, ou ele necessita de uma também renovada estrutura eclesial? Qual o lugar do catecumenato neste processo de renovação paroquial? Tem ele algo a dizer à busca de conversão paroquial? Em contrapartida, a paróquia, à medida que se renova, o que tem a oferecer à implantação do catecumenato? É fácil perceber a dinamicidade das perguntas, que comprometem ambos os lados. Não se trata de perguntas retóricas, mas questões que tocam a fundo a dinâmica desta pesquisa.

Portanto, analisadas as duas instituições separadamente, catecumenato e paróquia, retornaremos a elas, agora a partir de outro ângulo, o da aproximação, 
da fecundação, da cumplicidade, e porque não dizer da sadia dependência existente entre elas. Em termos mais precisos, retornaremos a elas no intuito de refletir sobre as perguntas acima feitas, e outras mais, subjacentes ao objetivo geral da tese. São questões que nos ajudam a sondar o grau de relação e sadia interferência entre nova estrutura paroquial e a consolidação da prática catecumenal. Nesta perspectiva, não nos interessa unilateralmente nem a iniciação à vida cristã catecumenal nem a instituição paroquial. Nosso objetivo geral é aproximar as duas realidades, confrontá-las, fazê-las dialogar, na busca de iluminação mútua. A isto daremos o nome de relação dialética. Portanto, os dois objetivos supra-citados, iniciação cristão catecumenal e renovação paroquial, estão subordinados a um objetivo maior: o elo, a aproximação existente entre eles. Torna-se oportuno insistir nesta questão: o objetivo principal a que se propõe esta pesquisa consiste em olhar a renovação paroquial à luz da pedagogia catecumenal, e vice-versa, ou seja, refletir a consolidação catecumenal à luz da paróquia em renovação. Desse vaivém, dessa feliz circularidade nascerão intuições, propostas que beneficiarão a ambos.

Outra observação relevante diz respeito a nossa não pretensão de apresentarmos um novo modelo de paróquia, mas abrir-lhes possibilidades novas a partir dos principais elementos da iniciação cristã catecumenal. A paróquia pode ser visto a partir de várias realidades específicas, todas com algo a contribuir para sua renovação ${ }^{1}$. Nossa missão consiste em olhar a paróquia a partir dos elementos da iniciação cristã catecumenal, e com eles dialogoar. A dinâmica do diálogo, da relação dialética por nós proposta, se dará a partir das etapas do catecumenato. Iremos confrontar seus elementos teológico-pastorais específicos e mais relevantes com aspectos paroquiais correspondentes ao espírito de cada etapa catecumenal em questão. O que o pré-catecumenato, por exemplo, tempo do primeiro anúncio missionário e querigmático, da atenção personalizada à pessoa, tem a dizer à missionariedade paroquial, ou a acolhida na paróquia, e esta aquela? Já na segunda etapa catecumenal, perguntaremos, entre outras questões, o que a intensa formação espiritual, humana, bíblica presente nesta etapa diz à formação permanente na paróquia? Em que a ministerialidade catecumenal, composta por

\footnotetext{
${ }^{1}$ É legítimo, por exemplo, refletir a renovação da instituição paroquial a partir das CEBs, das novas comunidades.
} 
uma rede de serviços e ministérios, ilumina ou questiona a estrutura ministerial da paróquia? Importa-nos também a pergunta inversa: para a efetivação da riqueza dos ministérios do catecumenato, como prevê o RICA, quais as mudanças necessária na estrutura ministerial paroquial? A mistagogia ${ }^{2}$, tão central à iniciação cristã, característica maior do paradigma da iniciação cristã catecumenal e última etapa do itinerário catecumenal, traz intuições nevrálgicas para o novo modelo de paroquial. Em que sentido que a mistagogia deve e pode ser a espinha dorsal na renovação paroquial?

Assim, não é difícil perceber a necessidade de aproximar as duas instituições em questão, cientes de que pastoralmente preocupar-se com apenas uma delas já não é capaz de levar a cabo o desafio da transmissão da fé. Iniciar na fé e garantir a proporcionar estruturas eclesiais adultas para a vivência desta fé são tarefas afins.

A fecundidade deste diálogo que nos propomos a estabelecer exige uma séria caminhada, o que justifica a estrutura da pesquisa, dividida em cinco capítulos. Para compreender as raízes teológicas, pastorais e culturais, tanto do desafio de iniciar na fé como da crise e necessidade da renovação paroquial, imprescindível se torna o olhar para a realidade que nos cerca. No primeiro capítulo, abordaremos o atual contexto sociocultural, marcado por profundas mudanças e tendências, cujas consequiências para a religião não são periféricas. O modelo de sociedade uniforme, sagrada, estática, objetiva, cede lugar à secularização, à mobilidade, ao pluralismo. Tais características atingem tudo e a todos, conforme já salientamos, inclusive a fé. 'Retorna, então, 'o sagrado, com as cores do pluralismo, da privatização, do individualismo, da mobilidade. Ao mesmo tempo, um mínimo de honestidade teológica exige afirmar que neste cenário de mudança de época reside possibilidade fecundas à fé, pois crise não significa necessariamente beco sem saída, mas possibilidade do novo.

Todo diálogo honesto requer a convicção da própria identidade. Sem a afirmação da própria identidade, a consciência das próprias limitações e a

\footnotetext{
${ }^{2}$ Neste particular, é de fundamental importância enfatizar que não obstante a mistagogia constituir uma etapa do itinerário da iniciação cristã catecumenal, não significa em absoluta que os outros momentos não sejam também mistagógicos. Ao contrário, o que caracteriza o catecumenato e responsável pela pertinência de sua pedagogia é a densidade mistagógica que permeia todos os momentos de sua proposta pastoral.
} 
confiança em suas potencialidades não se chega a um diálogo fecundo. Nesta perspectiva, para melhor dialogar com a instituição paroquial, no segundo capítulo entraremos na reflexão sobre os principais elementos teológicos e pastorais da iniciação à vida cristã. Identidade, teologia, desafios e possibilidades pastorais, renovação, novo paradigma de iniciação cristã serão a pauta do capítulo. A ênfase cairá na passagem do modo tradicional de iniciar na fé para o surgimento de um novo paradigma de iniciação, muito mais experiencial e vivencial, já em construção há algum tempo. Cresce a percepção de que o mergulho no mistério não se alcança com exposição de conceitos, mas fundamentalmente através da experiência pessoal e comunitária de Jesus Cristo.

Tendo refletido a natureza da iniciação à vida cristã, cujo significado maior é o mergulho existencial e sacramental no Mistério de Jesus Cristo, no terceiro capítulo entraremos na iniciação cristã catecumenal. Trata-se de um jeito todo próprio e original de transmitir e iniciar na fé, ou de mergulhar neste mistério, que remete aos primórdios do cristianismo. O catecumenato é hoje a grande descoberta da Igreja, e torna-se referência para as mais diversas formas de iniciar na fé. Apresentaremos o específico do catecumenato, seus principais elementos pastorais, pedagógicos e teológicos, sua estrutura, organizada em quatro etapas. Sobressairão aqueles elementos. Faremos também uma visita história ao catecumenato, desde seu surgimento, sua paulatina decadência, até sua recuperação proporcionada pelo último concílio ecumênico. O RICA, Ritual de Iniciação Cristã de Adultos, assumirá importância singular neste capítulo. Trata-se de um livro litúrgico onde está contida a inteira proposta pastoral da iniciação cristã catecumenal. Portanto, será ele nosso principal guia de reflexão ao apresentarmos a dinâmica catecumenal.

No quarto capítulo e início da segunda parte da tese, entraremos no tema da instituição paroquial. Com um rápido sobrevôo da história da paróquia, perceberemos facilmente que a identidade da paróquia está comprometida. A burocracia reinante, além do acentuado clericalismo, não responde às expectativas religiosas de quem deseja fazer uma profunda experiência de Deus. Não vem de hoje a constatação de que a paróquia atravessa uma profunda crise em configuração. Um objeto estranho parece ter entrado nas engrenagens de uma instituição bimilenar. Se há algum tempo a Igreja vem sentindo os abalos das 
mudanças socioculturais, hoje, no início do terceiro milênio, a crise parece chegar ao seu limite. Difícil esconder o mal estar existente entre o atual momento histórico e a vigente estrutura paroquial, nascida num contexto predominantemente rural.

Tentativas de revitalização da paróquia, seja na prática ou na reflexão, não são novidades. Nossa contribuição neste particular se dará a partir da dinâmica catecumenal. $\mathrm{O}$ quinto e último capítulo, a nosso ver onde reside a contribuição maior da pesquisa, se encarregará de aproximar iniciação cristã catecumenal e instituição paroquial. Trata-se de executar a relação dialética de que falávamos antes. Certamente aqui aparecerão intuições, propostas, provocações que lançam luzes a ambas as instituições, e cada vez mais aparecerá claro que iniciar na fé requer a necessidade de estruturas eclesiais adequadas.

Motivou-nos na escolha do tema aspectos preponderantemente de ordem pastorais. Experimentamos com intensidade os desafios impostos pelo contexto epocal, sobretudo numa realidade com alto grau de urbanização, como é o caso do Rio de Janeiro. Aqui, talvez mais do que em outros lugares, a transmissão da fé sofre como em dores de parto, mas ao mesmo tempo sabemos de experiências profundas da iniciação cristã. No tocante à paróquia, encantamo-nos com tal realidade, talvez por isso mesmo enxergamos seu cansaço institucional e ao mesmo tempo acreditamos em sua capacidade de renovação. Vale ainda lembrar que tal renovação é um processo, da mesma forma que a processual é a iniciação catecumenal na fé. Portanto, não apresentaremos de modo algum receitas prontas, ou modelos pré-estabelecidos, até porque a caminhada se faz caminhada.

A metodologia utilizada será a da pesquisa bibliográfica, juntamente com a observação pastoral nas realidades eclesiais onde desenvolvemos nosso trabalho pastoral. Nossa experiência, ainda que limitada, com o trabalho paroquial e nele, com o catecumenato terá uma importância fundamental no desenvolvimento do trabalho. Importa observar a limita bibliografia existente sobre a relação entre a paróquia e o catecumenato. Encontramos sim, abundantes obras sobre os dois temas, no entanto, não que trabalhem a relação entre eles. 


\section{FÉ CRISTÃ E A ATUAL CONJUNTURA SÓCIO CULTURAL- RELIGIOSA: O CONTEXTO EM QUE SE REALIZAM A INICIAÇÃO À VIDA CRISTÃ E A VIVÊNCIA DA FÉ}

"Antes de caminhar e de corrigir a caminhada, é preciso ver o caminho"3. As palavras do missiólogo Paulo Sues revelam a intenção do presente capítulo. Conhecer a estrada, dialogar com a cultura contemporânea não pode ser opcional quando nos propomos a refletir temas de tamanha significância para a teologia pastoral. A reflexão sobre a iniciação cristã e a estrutura paroquial requer um conhecimento do mundo no qual nos situamos, do qual aparecerão as dificuldades, mas também emergirão possibilidades para a evangelização.

\section{1}

\section{Mais do que época de mudança, mudança de época}

As profundas transformações ocorridas nas últimas décadas, com maior ou menor rapidez em todos os cantos do planeta, inaugura uma nova fase cultural na história da humanidade. 'Mudança de época', termo cunhado pela quinta conferência episcopal latino-americana, tem sido o que melhor expressa a radicalidade das mutações sucedidas em todas as dimensões da vida social, cultural e religiosa. Definitivamente, somos contemporâneos de uma nova etapa cultural, cuja definição semântica é complexa e de difícil unanimidade 4 . 'Pós-

\footnotetext{
${ }^{3}$ SUESS, P. "Não tenhais medo!" Da dificuldade de construir a "nova paróquia". In: Revista pastoral. Janeiro-fevereiro, 2014 - ano 55, número 294 (pp. 17-26), p. 17.

${ }^{4}$ É extremamente vasta a bibliografia sobre o assunto. Entre outros, cf. BAUMAN. Z. Modernidade Líquida, Rio de Janeiro: Jorge Zahar, 2001; VATTIMO. R. (org.). Il pensiero debole, Milão: Feltrinelli, 1992; LIPOVETSKY G. A sociedade da Decepção. Entrevista coordenada por Bertand Richard. São Paulo: Manole, 2007; LIPOVETSKY, G.; SERROY, J. A cultura-mundo: resposta a uma sociedade desorientada. São Paulo: Companhia das letras, 2011; GONZÁLES FAUS, J. I. Desafios da pós-modernidade. São Paulo: Paulinas, 1995; VATTIMO, G. O fim da Modernidade. São Paulo: Martins Fontes, 2002; KUMAR, K. Da sociedade pósindustrial à sociedade pós-moderna. Rio de Janeiro: Jorge Zahar, 1997; LIBANIO, J. B. Desafios da Pós-Modernidade à Teologia Fundamental. In: TRASFERETTI, J.; GONÇALVES, P. S. (orgs.) Teologia na Pós-Modernidade. Abordagens epistemológica, sistemática e teórico-prática. São Paulo: Paulinas, 2003; QUEIRUGA, A. T. Fin del cristanismo premoderno. Retos hacia um nuevo horizonte. Santander: Sal Terrae, 2000; SANTOS, M. Por uma outra globalização. Rio de Janeiro: Record, 2001; OLIVEIRA, M. A. A crise da racionalidade Moderna: uma crise de esperança. In: _ Ética e racionalidade moderna. São Paulo: Loyola, 1999; LYOTAR. La condición postmoderna: informe sobre el saber. Madrid: Cátedra, 1987; _ Moralidades
} 
modernidade', 'era pós-industrial', 'modernidade tardia', 'crise da modernidade' e até mesmo 'era pós-cristã' são algumas das expressões que revelam quão difícil se torna compreender o atual momento histórico. Contudo, tendo em vista o objetivo maior dessa pesquisa, mais importante do que o debate terminológico é perceber por onde passa a nova sensibilidade sociocultural trazida pela mudança epocal, atentos aos seus desafios e suas chances à transmissão da fé e à busca de uma configuração eclesial que lhe seja favorável.

Cientes de que, por fidelidade ao princípio da encarnação, o anúncio do Evangelho não pode abrir mão do esforço de falar ao ser humano a partir de seu contexto vital, julgamos que conhecer o hoje da história não é capricho intelectual mas a grande necessidade da ação evangelizadora, se quisermos que a Boa Nova seja pertinente para o homem contemporâneo. O enigma da esfinge egípcia 'decifra-me ou devoro-te' se faz atual por expressar a premência do diálogo com o presente, no intuito de conhecer as potencialidades e as dificuldades que o momento oportuniza. Quem não conhece a realidade não evangeliza. Se a ação evangelizadora não se faz cultura, essa se dá ao direito de se tornar indiferente à mensagem do Evangelho. Já bem recordava Aparecida ao afirmar que "o anúncio do Evangelho não se pode prescindir da cultura atual", que "deve ser conhecida, avaliada e em certo sentido assumida pela Igreja" (DAp, 480) ${ }^{5}$.

$\mathrm{Na}$ tentativa de expressar o que vem a ser a mudança de época, Lipovetsky e Serroy, profundos conhecedores da cultura contemporânea, afirmam estarmos vivendo uma cultura-mundo, isto é, a universalização de certos pressupostos que dão a tônica sócio cultural. 'Hipermodernidade', hipercapitalismo, hipertecnologia, hiperindividualismo e hiperconsumismo são, segundo os autores, os pilares sob os quais a cultura hodierna se apóia. "Impõe-se a cultura ampliada do capitalismo, do individualismo, e da tecnociência, uma cultura globalitária que estrutura de maneira radicalmente nova a relação do homem consigo e com o mundo"6.

posmodernas. Madrid: Tecnos, 1998; _ La postmodernidade explicada a los niños. Barcelona: Gedisa, 1987.

${ }^{5}$ DOCUMENTO DE APARECIDA: Texto conclusivo da V Conferência Geral do Episcopado Latino-Americano e do Caribe. São Paulo: Paulus, 2007, n. 480.

${ }^{6}$ LIPOVETSKY, G.; SERROY, J. A cultura-mundo, op. cit., p. 11. 
$\mathrm{Na}$ mesma perspectiva, Leonardo Boff afirma que a atual cultura “participa de todos os pós-ismos (pós-histoire pós-industrialismo, pósestruturalismo, pós-socialismo, pós-marxismo, pós cristianismo, etc)"7. Nesta perspectiva, um novo paradigma sócio cultural se impõe. Mais do que época de mudança "vivemos uma mudança de época, e o seu nível mais profundo é o cultural” (DAp, 44). Enquanto que épocas de mudança atingem, via de regra, o periférico da dinâmica sócio cultural, mudanças de época dizem respeito às alterações dos valores e dos critérios de julgamentos, emergindo daí uma nova compreensão do ser humano, da sociedade, do indivíduo, da religião, do econômico, do político, da ética, do tempo e do espaço, apenas para mencionar algumas das principais mutações sócio existenciais. Seguindo a dinâmica do método ver, julgar e agir, a época de mudança está relacionado mais ao ver, ao passo que a mudança de época se aproxima do julgar, uma vez que atingem os valores a partir dos quais a realidade é vivida, olhada e assumida ${ }^{8}$.

Um modelo de sociedade está passando e outro vem chegando, trazendo consigo novos valores e contra valores. Toda transição cultural traz crise, daí se entende a perplexidade, ansiedade, insegurança, fundamentalismo, relativismo, confusão, incerteza presentes em nosso cotidiano. Todavia, a crise traz consigo a semente das possibilidades; novas perspectivas se abrem. Se são muitos os desafios, não menos são as chances, pois a atual cultura "carrega em si o melhor e o pior"9. Positividade e negatividade se misturam, exigindo discernimento, criatividade e coragem, ainda mais em se tratando do anúncio do Evangelho. Importa perceber a afirmação de uma realidade nada homogênea e não menos complexa, a qual não deve desencorajar o trabalho evangelizador.

\section{2}

\section{Crise do paradigma moderno racionalista e a emergência de uma nova sensibilidade sócio cultural}

\footnotetext{
${ }^{7}$ BOFF, L. A voz do arco-iris. Brasília: Letraviva, 2000, p. 17.

8 Cf. AMADO, J. P. Catequese num mundo em transformação: desafios do contexto sóciocultural, religioso e eclesial para a iniciação cristã. In: Revista de Catequese. São Paulo: Unisal, ano 32, n. 128, outubro/dezembro 2009, p. 10.

${ }^{9}$ VALADIER, P. Catolicismo e sociedade moderna. São Paulo. Loyola, 1991, p. 57.
} 
Apesar da ruptura entre idade medieval e a modernidade ter seu início com a chegada dos europeus às Américas (1492), é a partir do paradigma cartesiano que a modernidade vai se estruturar e se desenvolver ${ }^{10}$, cuja chave de leitura da realidade é a razão instrumental. Nesta guinada cultural, o teocentrismo da escolástica medieval é substituído pelo antropocentrismo racional. Se antes as respostas existenciais eram encontradas em Deus e nas forças sobrenaturais, com o advento da modernidade elas vão ser buscadas no racionalismo instrumental matemático e nas descobertas científicas.

A verdade passa a ser aquilo que pode ser comprovada logicamente, daí os valores espirituais, presentes no cotidiano das pessoas serem enfraquecidos pela crença no racional. O cosmo sagrado da revelação é substituído pelo eu, que passa a ser o critério de conhecimento da realidade.

Outras formas de conhecimento, como por exemplo, o senso comum, a subjetividade, a intuição são suplantadas pela supervalorização da razão e do conhecimento objetivo, que garantiam a segurança e a ordem social. Tendo como precursor Descartes, para quem a razão é capaz de decifrar todos os mistérios do conhecimento e da realidade, outros pensadores como Kant, Hegel, Marx, Nietzsche, Heidegger, Habernas endosam a lista dos principais responsáveis pelo paradigma moderno, cuja difusão maior se dará no iluminismo e na Revolução Industrial nos séculos XVIII e XIX ${ }^{11}$. De acordo com Boaventura Santos, o fenômeno intelectual denominado 'Luzes' dará à luz as ciências sociais do século XIX, a partir das quais "só há duas formas de conhecimento científico - as disciplinas formais da lógica e da matemática e as ciências empíricas segundo o modelo mecanicista das ciências naturais - as ciências sociais nasceram para ser empíricas"12. Não é difícil perceber a influência de tal matriz cultural sobre o edifício religioso cristão. O cristianismo como um todo, no seu conjunto de doutrinas e normas, a teologia com seus tratados e a configuração eclesial

\footnotetext{
${ }^{10}$ Cf. VAZ, L. H. Raízes da modernidade ou fim de uma era teológica? In: Escritos de Filosofia VII. São Paulo: Loyola, 2002, p. 29; PALÁCIO, C. Novos paradigmas ou fim de uma era teológica? In: FABRI, M (org). Teologia aberta ao futuro. São Paulo: Soter/Loyola, 1997, p. 84.

${ }^{11}$ Cf. AZEVEDO, M. C. Não moderno, moderno e pós-moderno. In: Revista de Educação da AEC. Ano 22, n. 89, 1993, p. 21.

${ }^{12}$ SANTOS. B. S. A crítica da razão indolente contra o desperdício da experiência. São Paulo: Cortez, 2007, p. 67.
} 
beberam demasiadamente da fonte racionalista cartesiana, haja vista o divórcio entre teologia e espiritualidade no ocidente.

Contudo, os pilares sobre os quais o paradigma moderno se alicerçou começam a trincar. A divinização da razão científica instrumental se vê impotente para satisfazer as necessidade e responder às perguntas emergentes da nova sensibilidade que começa a ser desenhada. Os excessos do paradigma moderno são geradores de crise e de insatisfação. Verifica-se uma desilusão com o mito do ilimitado progresso científico.

O audacioso projeto da modernidade, pautada no racionalismo, ou no que Bauman chamou de 'sonho da razão legislativa'13, não se deu conta de que a pretensão absoluta do saber, a confiança ilimitada na razão não seriam capazes de responder aos anseios mais profundos do humano. Além dos sonhos humanos não terem lugar no racionalismo ocidental ${ }^{14}$, alguns acontecimentos colocaram em xeque a pretensa inteligência científica. As duas guerras mundiais, a crise ecológica, a invenção de armas de destruição entre outras derrotas da inflexibilidade racionalista deram a luz à crise moderna.

Entra em crise um paradigma cultural dominante e uma nova sensibilidade cultural e religiosa vai emergindo, cujo nascimento coincide com as novas descobertas da física quântica a qual oferece uma nova percepção da realidade ${ }^{15}$. Seja o 'pensiero debole' de Vattimo, seja a 'sociedade líquida' de Bauman, ou o 'homem light' de Rojas ${ }^{16}$, fato é que se apresenta uma nova racionalidade, 'alargada', 'holística', que leva em consideração outras dimensões da existência, como o afeto, a emoção, a paixão, a intuição, a imaginação, a subjetividade.

O novo olhar substituto da cosmovisão moderna recusa certos aspectos, relativiza outros e maximiza outros tantos, haja vista o lugar marginal que ocupam as instituições, se compararmos à centralidade que recebe o indivíduo na atualidade. $\mathrm{O}$ racionalismo perde força para o subjetivo emocional, a tradição é recusada em nome da necessidade da escolha e de uma suposta liberdade. O

${ }^{13}$ BAUMAN, Z. Modernidade e Ambivalência. Rio de Janeiro: Jorge Zahar Editor, 1999, p. 29.

${ }^{14}$ Cf. WEBER, M. A ética protestante e o espírito do capitalismo. São Paulo: Pioneira, 1989, p. 11 .

${ }^{15}$ Resulta daí uma nova percepção do universo, entendido como uma realidade viva e dinâmica, uma rede interligada de relações e interdependência. Cf. CAPRA, F. $O$ ponto de mutação: a ciência, a sociedade e a cultura emergente. 25 ed. São Paulo: cultrix, 1982.

${ }^{16}$ Cf. ROJAS, E. El hombre light: uma vida sin valores. Madrid, 1992. 
transitório, o efêmero, a novidade atraem mais que o tradicional e o estático. $\mathrm{O}$ estético sobressai ao ético, sem falar no pluralismo que, sem sombra de dúvida, é a grande marca cultural hodierna, deixando para trás o homogêneo, seja ele religioso, cultural, político. Vale lembrar que a nova percepção não é hegemônica. No novo cenário cultural convivem a visão mecanicista-atomista da modernidade e a nova inteligência panrrelacioanal ${ }^{17}$.

Michel Mafessoli é un dos mais entusiasmados com o momento atual. Para o sociólogo francês, o momento é de 'reencantamento do mundo' ${ }^{\text {'18. Segundo }}$ Maffesoli, a riqueza do momento está na valorização da experiência, do cotidiano, dos reagrupamentos, cuja tônica é o afeto, o estar junto, ainda que a recusa a qualquer projeto político ou outra finalidade especifica ${ }^{19}$. Sociólogos como Maffessoli entre tantos outros, sem renunciarem à postura crítica, nos ensinam que a nostalgia do antigo deve dar passagem à esperança do novo.

O que pretendemos a seguir é um sobrevôo, ainda que superficial, nas principais características da mudança de época em andamento. Sem a pretensão de esgotar o assunto, elencaremos alguns dos principais aspectos que mais desafiam a ação evangelizadora, ao mesmo tempo em que são portadoras de esperança e possibilidades para o anúncio do Evangelho.

\section{3}

\section{Principais características do atual paradigma cultural}

Por serem as mudanças em questão por demais profundas e complexas somos cientes da incapacidade de uma abordagem completa das mesmas, o que nos resta tão somente apontar algumas das principais características sócio culturais que mais incidem na transmissão da fé, que por sua vez exigem nova configuração eclesial.

\subsection{1}

\section{O pluralismo cultural e religioso}

\footnotetext{
${ }^{17}$ BOFF, L. A voz do arco-iris, op. cit., p. 101.

${ }^{18}$ Cf. MAFFESOLI, M. Le réenchantement du monde. Une éthique pour temps. La Table Ronde: Paris, 2007.

${ }^{19}$ Cf. MAFFESOLI, M. A transfiguração do político, a tribalização do mundo. Porto Alegre: Sulina, 2005; cf. MAFFESOLI, M. O tempo das tribos. O declínio do individualismo nas sociedades de massa. 4. ed. Rio de Janeiro: Forense Universitária, 2006.
} 
O modelo de sociedade homogênea e uniforme da cultura moderna se vê hoje obrigado a conviver com a irrupção do pluralismo em todas as suas manifestações. A sociedade atual caracteriza-se primeiramente pelo pluralismo, na qual coexistem uma multiplicidade de fontes de sentido e leituras da realidade ${ }^{20}$.

Decorrente de vários fatores, dentre os quais destacam-se os movimentos migratórios, a inter-relação de povos e culturas, a rapidez da comunicação, a facilidade de locomoção e o avanço da tecnologia, o pluralismo no qual estamos inseridos afirma-se como uma realidade sócio cultural, gerador de diferentes subculturas, costumes, idéias e valores num mesmo ambiente. Diariamente nos confrontamos com novas linguagens, pensamentos, novos saberes e sabores, o que nos dá a impressão de sermos estranhos em nossa própria casa.

Vivemos em meio a uma explosão de diferenças. A atual cosmovisão é plural $^{21}$, as culturas são policêntricas, ou seja, várias fontes de sentido oferecem uma leitura da realidade, o que significa que já não existe mais um princípio norteador para o todo social. Trata-se de um processo iniciado séculos atrás, quando cada setor da sociedade, como o político, o econômico, o religioso começaram a construir fontes de sentido próprios. No exercício de sua autonomia e autocompreensão, tais instâncias prescindem daquela visão única e unificadora do cosmo, cujo pano de fundo era a fé cristã ${ }^{22}$. Em outras palavras, a visão homogênea da realidade é desfeita, ficando ao encargo de cada setor se apresentar como própria fonte de sentido e orientação de vida.

Uma análise mais detalhada do atual pluralismo irá mostrar, portanto, que seu pano de fundo está na recusa do predomínio universal ou totalizante que de certa forma oferecia uma explicação única e universal da realidade. Segundo Lyotard, “o pós moderno, enquanto condição da cultura nesta era (pós-industrial) caracteriza-se exatamente pela incredulidade perante o metadiscurso filosóficometafísico"23. As grandes narrativas, fornecedoras de sentido são substituídas por

\footnotetext{
${ }^{20}$ MIRANDA, M. F. Um catolicismo desafiado: Igreja e pluralismo religioso no Brasil. São Paulo: Paulinas, 1996, p. 13.

${ }^{21}$ Cf. MARIZ, C. L. Catolicismo no Brasil contemporâneo: reavivamento e diversidade. In: TEIXEIRA, F.; MENEZES R. (orgs.). As religiões no Brasil: continuidades e rupturas. Petrópolis: Vozes, 2006, p. 59.

${ }^{22}$ Cf. MIRANDA, M. F. A Igreja numa sociedade fragmentada. São Paulo: Loyola, 2003, p. 60.

${ }^{23}$ LYOTARD, J. F. O pós-moderno. RJ. Olympio Editora, introdução, viii, 1986.
} 
pequenos relatos, cujos resultados são variedades de fragmentos, por vezes desconexos entre si.

Explicação única do ser humano, da história, da religião já não satisfazem mais. Surgem, então, a era do questionamento das ortodoxias, dos domínios, do uno, da tradição, do estático. A grande exigência do momento está em esquecer as metanarrativas em nome de uma práxis localizada, ou seja, de uma práxis de pluralidade e possibilidades infinitas ${ }^{24}$.

O pluralismo traz para o conjunto social ganhos inquestionáveis à medida que alarga o leque de visões, possibilitando o aprendizado na convivência com o diferente. Contudo, autores chamam a atenção para o perigo do pluralismo se converter em relativismo. Uma vez que deixa de existir um modelo único, ou se quisermos, uma padrão de referência, a tendência é adentrar pelos caminhos da tolerância relativista. Do monoteísmo de valores e crenças, fundamentada em uma única razão filosófica, pode-se passar ao 'politeísmo de valores', a cosmovisões e princípios subjetivos $^{25}$, daí a fragmentação social. Na intuição de Bauman, instaura-se uma 'modernidade líquida', em contraposição a um mundo ‘sólido' e pesado', delimitado, estruturado, com regras claras e posturas definidas ${ }^{26}$. A ordem da vez tende a ser o provisório, o efêmero, a leveza, o sofware', o relativo.

Da mesma pluralidade participa o fenômeno religioso, por ser parte integrante da dinâmica sócio cultural. Diferentes credos, práticas, filosofias, pertenças, orientações existenciais compõem o atual quadro religioso. Esoterismo, sincretismo, new age, magia, práticas, orientações, fenômeno neopentecostal, religiosidades não institucionalizadas, novos movimentos religiosos e novas espiritualidades são algumas das expressões do vasto, complexo e plural campo religioso contemporâneo.

As últimas pesquisas realizadas no Brasil sobre a religiosidade do país têm mostrado a face plural da religião brasileira ${ }^{27}$. Surpreende a diversidade de expressões religiosas existentes em um país onde há pouco tempo o catolicismo

${ }^{24}$ OLIVEIRA, M. A. Pluralismo e Ética. In: OLIVEIRA, M. A. Ética e Práxis Histórica. São Paulo: Ática, 1995, pp. 164-165.

${ }^{25}$ Cf. VELASCO, J. M. Ser Cristiano en una cultura posmoderna. PPC: Madrid, 1996, p. 51.

${ }^{26}$ Cf. BAUMAN. Z. Modernidade Líquida, op. cit., 2001.

${ }^{27}$ Entre elas cf. SOUZA, L. G; FERNANDES, S. R. A. (orgs.). Desafios do catolicismo na cidade: pesquisas em regiões metropolitanas brasileiras. CERIS-São Paulo: Paulus, 2002; JACOB, C. R. et all. Atlas da filiação religiosa e indicadores sociais no Brasil. Rio de Janeiro/PUC-RJ/Loyola, 2003. ORO, I. P. O fenômeno religioso: como entender. São Paulo: Paulinas, 2013. 
ditava as normas do jogo de significações simbólicas do indivíduo e da sociedade. Embora continue sendo a religião majoritária, o catolicismo se vê hoje no desafio de conviver com um imenso número de opções religiosas, diante das quais o sujeito se sente à vontade para escolher aquela que mais lhe satisfaz.

Por estarmos numa sociedade secularizada, na qual a religião é assunto que diz respeito ao âmbito individual, os monopólios religiosos, até então fornecedores das chaves de leitura de realidade cedem lugar a uma diversidade de crenças, práticas, grupos, enfim, às mais diversas possibilidades de experimentar o sagrado, concorrendo entre si no vasto mercado religioso ${ }^{28}$.

As diversas e novas expressões religiosas, via de regra plurais em si mesmas, vão desconstruindo antigos monopólios religiosos e firmando-se como uma visível reação a qualquer tentativa de 'domesticação' do sagrado. Para Peter Berger, "os ex-monopólios religiosos não podem mais contar com a submissão de suas populações. A submissão é voluntária"29.

Decorre da plural e abundante oferta religiosa disponível ao indivíduo contemporâneo uma acirrada concorrência religiosa. As religiões, para sobreviverem se veem obrigadas a entrar na lógica do mercado. Em matéria de religião, o que antes era imposta pela autoridade, hoje, precisa ser colocada no mercado religioso. As instituições religiosas tornam-se agências de mercado e as tradições religiosas tornam-se artigos de consumo ${ }^{30}$. Consequência disto é a indiferença religiosa, fenômeno este muito próximo ao fenômeno do pluralismo religioso. $\mathrm{O}$ aumento de religiões gera o sentimento de que tanto faz aderir a esta ou aquela religião, ou então não aderir a nenhuma deles. "Percebe-se que o pluralismo está na base do indiferentismo, que é outra tendência. As coisas estão aí, pode-se escolher. É indiferente, tanto faz uma como outra"31.

Não é difícil perceber o quanto o quadro acima exposto atinge o cristianismo como um todo, e particularmente o catolicismo, acostumado há séculos a uma posição, se não de exclusividade, ao menos de hegemonia absoluta, cuja cosmovisão foi responsável por plasmar a cultura ocidental. Embora o

\footnotetext{
${ }^{28}$ Cf. MARTELLI, S. A Religião na sociedade pós-moderna: entre a secularização e a dessecularização. São Paulo: Paulinas, 1995, p. 290.

${ }^{29}$ BERGER, P. L. O Dossel sagrado: elementos para uma teoria sociológica da religião. São Paulo: Paulus, 1985, p.149.

${ }^{30}$ Cf. Ibid., 1985.

${ }^{31}$ ORO, I. P. O fenômeno religioso, op. cit., p. 61.
} 
catolicismo ainda seja a religião majoritária do país, as pesquisas mostram que pluralismo religioso e perda gradativa de católicos são dois lados de uma mesma moeda. O Brasil vem se descatolicizando, e entra em xeque a equação Brasil = catolicismo, conforme revela as estatísticas do IBGE. Em 1872, 99\% dos brasileiros eram católicos. Em 1890, esse número caiu para 98,9\%, chegando aos 95,0\%, em 1940. Já em 1950, a queda atinge os 93,5\%, chegando os 91,8\% em 1970 e 88,4\% em 1980. Nos anos de 1990, 83, 8\% dos brasileiros se diziam católicos. Na última década, o número cai para 73,8\%, uma perda de $10 \%$. A última pesquisa, 2010, revelou que o atual percentual de católicos no país caiu para $64,6 \%$, enquanto que os evangélicos foram os que mais cresceram, hoje com $22,2 \%$. Tamanha queda deu ao catolicismo o título de 'doador universal de fiéis ${ }^{32}$. Diante do novo cenário religioso, o catolicismo terá que aprender a conviver com a diversidade, o que nem sempre é fácil.

\subsection{2}

\section{Declínio do institucional e centralidade do indivíduo}

O pluralismo das sociedades avançadas é, de certa forma, responsável pela crise por que atravessam as instituições sociais. A família, a escola, a política, a religião, apenas para mencionar as principais instâncias sociais, responsáveis pela transmissão de valores, padecem do que os estudiosos chamam de "processo de desistitucionalização'. Não mais as instituições e sim o indivíduo, a partir de suas convicções pessoais e subjetivas, chama para si a responsabilidade de referenciar a própria existência. O cultural já não se organiza mais ao redor de fortes estruturas sociais ou institucionais. Daí a centralidade da subjetividade, do individualismo, da autonomia na atual reviravolta cultural. Conceitos sociais fundamentais como, por exemplo, a ética, a verdade, o sujeito, Deus, lei, são ressignificados segundo as motivações do mundo interior. Como afirma David Harley em sua clássica obra 'Condição Pós-moderna', “ ... a confiança na associação entre juízes científicos e morais ruiu, a estética triunfou sobre a ética

\footnotetext{
${ }^{32}$ Cf. Ibid.; Cf. MONTEIRO, P.; ALMEIDA, R. M. O campo religioso no limiar do século. Problemas e perspectivas. In: RATTNER, H. Brasil no limiar do século XXI. São Paulo: Fapesp/Edusp, 2003, p. 330.
} 
como foco primário de preocupação intelectual e social, as imagens dominaram as narrativas..."33.

A verdade, se até o crepúsculo da modernidade era submetida à analise da razão e da ciência, hoje, na aurora da nova sensibilidade cultural, deixa de ser algo imutável e objetivado para se tornar ser uma realidade construído social e subjetivamente. A verdade que não advém da própria experiência ou da própria formulação tende a ser rejeitada.

Todos os vínculos e pertenças sociais passam a ter sentido a partir do momento que o próprio indivíduo os tece, os quais podem ser facilmente rompidos em nome da liberdade, do estatuto de individuo democrático. Vivemos a "emancipação do indivíduo em face às imposições coletivas"34. Num mundo marcado pela "anomia social, as pessoas já não tem mais parâmetros adequados de medir a viabilidade de seus desejos". ${ }^{35}$ Conclui França Miranda, "cada um, diante da generosa diversidade de fontes, de sentido para a vida, de cunho cultural ou religioso, deve fazer uso de sua liberdade e optar pessoalmente pelo caminho a seguir" 36 .

Lipovetsky é quem nos ajuda a melhor entender a lógica do individualismo. Para ele vivemos um segunda fase do individualismo, 'uma segunda revolução individualista" ${ }^{37}$, cujos sinais mais evidentes estão na nova relação com o corpo, na obsessão pela imagem, na cultura do desejo, na busca de refúgios psicologizantes, na ditadura do prazer. Passamos de um individualismo limitado a um individualismo hipermoderno, desordenado. Ou seja, chegou o momento da crise radical dos antigos freios que garantiam o equilíbrio da autonomia individual. Para o mesmo autor, esgotou-se o tempo do 'tu deves'. 38 Interessante é a observação de Manfredo Oliveira, para quem, enquanto que "a

\footnotetext{
${ }^{33}$ HARVEY, D. Condição Pós-moderna. São Paulo: Edições Loyola, 1992, p. 293.

${ }^{34}$ LIPOVETSKY, G. A Sociedade da decepção, op. cit., p. 2.

${ }^{35}$ Ibid., p. 8.

${ }^{36}$ MIRANDA, M. F. A Igreja numa sociedade fragmentada, op. cit., p. 61.

${ }^{37}$ Cf. LIPOVETSKY, G. La era del vacío. Barcelona, Anagrama, 1986. Segunda revolução no sentido de que antes tratava-se de um individualismo coletivo, a autonomia das instituições, enquanto que hoje é a busca de uma liberdade individualista no cotidiano das relações que predomina.

${ }^{38}$ Cf. LIPOVETSKY, G. El crepúsculo del deber. La ética indolora de los nuevos tiempos democráticos. Barcelona: Espanha: Editora Anagrama, 1994, p. 46.
} 
subjetividade moderna era a subjetividade da razão instrumental, a pós'-moderna era a subjetividade do desejo" ${ }^{\text {39. }}$.

Da mesma crise do institucional participam as tradições sociais e religiosas, cuja lógica é a mesma: desejo de libertar-se das imposições coletivas e sociais. Os laços familiares, a influência da família nas gerações futuras cada vez mais tornam-se fragilizados e os centros de transmissão estão em crise agonizantes. Vivemos na sociedade da informação, mas de pouca transmissão ${ }^{40}$.

O declínio do institucional e a ascensão do individual, se de um lado trouxe ganhos no tocante à conquista de uma maior liberdade, por outro, não deixou de gerar uma sociedade fragmentada. É o paradoxo da 'liberdade' pós-moderna. Na mesma proporção que se busca usufruir das conquistas atuais cresce a insegurança e o medo, inaugurando a sociedade do 'risco', do pensamento 'débil'41, da decepção, da ansiedade. $\mathrm{Na}$ 'era do vazio', quanto mais o indivíduo senten-se senhor de si, tanto mais aparece vulnerável, frágil, desarmado internamente ${ }^{42}$. Prova disso é o crescimento dos suicídios, o aumento da dependência química, toxomania, depressão etc.

A sociedade hipermoderna é propriamente aquela que multiplica ao infinito as ocasiões de experiências frustantes ... Quando se põe em destaque um fantasioso conceito de 'carência zero' generalizante, como é possível escapar do aumento da decepção ${ }^{43}$.

A reflexão de França Miranda ajuda a entender ainda melhor a ansiedade que marca nossa época.

Ninguém está completamente à vontade na sociedade pós-moderna. Estamos todos contaminados por uma epidemia silenciosa de insegurança e de angústia. A oferta generosa e abundante de definições da realidade, à semelhança de um shopping bem sortido, garante ao indivíduo maior espaço para sua liberdade, mas

\footnotetext{
${ }^{39}$ OLIVEIRA, M. A. Cristianismo e construção da cidadania. In: Revista de Teologia e Ciências da Religião da Unicap. Recife, ano VII, 2008, n. 7, p. 14.

${ }^{40} \mathrm{O}$ pensador francês R. Debray elabora uma excelente distinção entre informação e transmissão. Transmissão longe de ser mera experiência imediata, permite criar um sistema de significações entre uma geração e outra, entre o passado e o presente. Cf. DEBRAY, R. Introduction à la médiologie. Paris: PUF, 2000, chapitre 1: Le temps de la transmiission, 1-32; hic 2-6, citado por LIBÂNIO, J. B. Jovens em tempos de pós-modernidade: considerações socioculturais e pastorais. São Paulo: Loyola, 2004, pp.128-129.

${ }^{41}$ Cf. VATTIMO. R. (org.). Il pensiero debole, Milão: Feltrinelli, 1992. Sobre a sociedade da decepção cf. LIPOVETSKY G.; SERROY, J. A sociedade da Decepção, op. cit.

${ }^{42}$ Ibid., p. 55.

${ }^{43}$ Ibid., p. 6.
} 
simultaneamente, descarrega sobre ele o difícil ônus de construir sua própria identidade sem lhe oferecer referências solidas ${ }^{44}$.

Por se a sociedade pós-moderna marcada por paradoxos, apesar do agudo grau de narcisismo não reina um egoismo absoluto. Cresce o individualismo mas nem por isso desaparecem as buscas comunitárias, o voluntariado, a consiência ecológica, protestos contra formas ditatoriais etc. Portanto, um nivelamento por baixo do individualismo contemporâneo não faz jus à realidade, uma vez que na mesma cultura, ou se quisermos, em cada ser humano, coabita o indivíduo irresponsável, ilimitado e o indivíduo responsável.

\subsection{3}

\section{O fenômeno da globalização}

Embora as características da mudança epocal expostas nos itens anteriores já terem indiretamente abordado o fenômeno universalizante da globalização, cabe ainda alguns aspectos que melhor exprimem tais fenômenos. Priorizaremos agora as categorias do tempo, do espaço e do econômico.

Globalização, urbanização, mundialização são termos de certa forma equivalentes à medida que expressam o alcance universal das mudanças sócio culturais, religiosas, econômicas e políticas em curso. Diferentemente do que se possa imaginar, a globalização diz respeito não somente à esfera econômica, mas atinge aspectos globalizantes da cultura sócio existencial. Por ser a globalização um conjunto de relações sócio culturais no qual vários aspectos estão envolvidos, Boaventura de Souza Santos tem preferido o uso no plural. Globalizações, segundo o autor, exprime com mais precisão o que se passa nos bastidores de um fenômeno sem precedente na história ${ }^{45}$.

$\mathrm{O}$ atraente do processo globalizador está na articulação entre o local e o global. Através do fenômeno da globalização, determinada condição ou entidade local tem a força de influenciar o global ao mesmo tempo em que consegue fortalecer o local. Neste sentido, as fronteiras não são respeitadas, as culturas invadidas, porém concomitantemente criam-se espaços locais e culturais, 'tribos', na linguagem de Maffesoli ${ }^{46}$, nas quais as identidades e etnias são reafirmadas. No

\footnotetext{
${ }^{44}$ MIRANDA, M. F. A Igreja numa sociedade fragmentada, op. cit. p.264.

${ }^{45}$ SANTOS, B. S. A gramática do tempo. São Paulo: Cortez, 2006, p. 438.

${ }^{46}$ Cf. MAFFESOLI. M. O tempo das tribos, op. cit.
} 
esforço de apontar para a fusão entre o global e o local tem-se utilizado a expressão globalização ${ }^{47}$. O responsável direto pelo alcance global das transformações culturais e pela abrangência universal das invenções e inovações é indiscutivelmente o alto desenvolvimento tecnológico dos meios de comunicação. A comunicação é simultânea e instantânea, já não sendo mais imprescindível sair de um lugar para estar num outro em tempo real. Basta um clique para se interagir com o mundo e dele receber ou fornecer informações sobre quaisquer assuntos. Vivemos na 'sociedade das telas' e 'das redes'. Assistimos a uma genuína ‘ revolução digital', na expressão de Dreifus, através da qual a cultura tecnocientífica invade o planeta e estende seu domínio a todos os cantos do mundo ${ }^{48}$.

O avanço tecnológico percorre o mundo da informação e da comunicação, passa pelas biotecnologias, visita a bioquímica e as nanotecnologias, e novas trilhas estão sendo abertas. Na era da globalização planetária e da tecnização da cultura, o humano torna-se capaz de modificar não somente a natureza mas a própria vida humana ${ }^{49}$. Em outros termos, as novas tecnologias ditam o ritmo das relações e da vida cotidiana aqui e acolá.

No que tange ao mundo da comunicação, Lipovetsky afirma a passagem de um modelo de comunicação unilateral para um modelo horizontal de comunicação. O ser humano deixa de ser um mero receptor da mensagem para se tornar um construtor da comunicação. Beneficiando-se de uma infinidade de recursos, face, blogs, redes sociais, youtube, msn, entre tantos outros surgidos diariamente, ele constrói a própria comunicação, por meio da qual troca experiências, expõe seus sentimentos, interage com quem e quando quiser. "Abrese uma nova página da comunicação, que se vê fragmentarem-se as audiências e erodir a 'onipotência' das grandes mídias de massa: passou-se da tevê soberana ao internauta-rei" ${ }^{50}$. A televisão é destronada do papel de representando da comunicação unilateral, através de seu poder das imagens direta e transmissão dos

\footnotetext{
${ }^{47}$ Cf. FRIEDMAN, T. O mundo é plano: uma breve história do século XXI. Rio de Janeiro: Objetiva, 2007, pp. 420-426.

${ }^{48}$ Cf. DREIFUSS R. A época das perplexidades. Mundialização, globalização e planetarização: novos desafios. Petrópolis: Vozes, 2001, p.18.

${ }^{49}$ LIPOVETSKY, G.; SERROY, J. A cultura-mundo, op. cit., p. 44.

${ }^{50}$ Ibid., p. 78 .
} 
conteúdos recebidos, e em seu lugar está o próprio indivíduo, como produtor e consumidor da mensagem.

O grande ganho da globalização sem sombra de dúvidas está no resgate de uma consciência mais planetária, uma percepção mais global e holística da existência ${ }^{51}$, o despertar do sentimento de interdependência entre o local e o global, entre o micro e o macro, uma vez que nossos hábitos de vida são influenciados por eventos ocorridos em outros lugares, bem como costumes locais acabam tendo influência global. O progresso trouxe frutos incalculáveis, haja vista a melhoria da qualidade de vida. Contudo, como todo processo é portador de luzes e sombras, a ferida aberta pela cultura tecnocientífica concentra-se no econômico, cuja primazia sobre os outros setores da sociedade indiscutivelmente salta aos olhos. Com propriedade afirma Aparecida que "na globalização, a dinâmica do mercado absolutiza com facilidade a eficácia e a produtividade como valores reguladores de todas as relações humanas" (DAp 61). A economia, regida pela lei do mercado, sob o jogo de interesses, transforma-se em palavra chave ${ }^{52}$.

Novamente é Gilles Lipovetsky quem aprofunda o tema. Segundo o autor o que mais caracteriza a 'cultura-mundo' é a primazia do econômico, entendido como um sistema organizador do mundo. O cultural, na atualidade, é identificado com conteúdos produzidos, consumidos e vendidos. O triunfo do hipercapitalismo não somente econômico, mas cultural, atinge o imaginário coletivo e individual, o pensar, a relação, os objetivos da existência, da educação, da política ${ }^{53}$.

A totalidade do social cai na rede do marketing. Nem mesmo a religião escapa da lógica mercantil. Os efeitos da lógica mercantil sobre a vivência e a transmissão da fé são gritantes, haja vista o sucesso da teologia da prosperidade. $\mathrm{Na}$ dinâmica mercantilista religião passa a ser bom negócio; inaugura-se uma aproximação inédita entre sagrado e mercado, conforme testemunha o crescimento das agências de cura divina, prometedoras de salvação espiritual e material. Para Joel Portela,

\footnotetext{
${ }^{51}$ Já fizemos alusão à contribuição da física moderna para uma nova percepção da realidade. Vale a pena indicar novamente a obra de CAPRA, F. O ponto de mutação, op. cit., 1982.

${ }^{52}$ MIRANDA, M. F. Um homem perplexo: o cristão na atual sociedade. São Paulo: Loyola, 1996, p.11.

${ }_{53}^{5}$ Cf. LIPOVETSKY, G.; SERROY, J. A cultura-mundo, op. cit., p. 38.
} 
Ainda que, através de matizes variadas, o que assistimos hoje é uma emergente concepção de Deus como solução imediata, rápida e mágica para os problemas da imanência. Em outras, aquilo que o mercado não fornece, espera-se que Deus forneça ${ }^{54}$.

O acúmulo do capital e o domínio das transnacionais comandam o mundo e impõem seus ritmos aos demais países emergentes, aumentando a distância entre os que muito têm e os que nada possuem. "Enquanto feixes de relações sociais, as globalizações envolvem conflitos e, por isso, vencedores de vencidos" ${ }^{25}$.

O consumo deixa de ser apenas conseqüência da produção de mercadorias para se tornar uma necessidade imposta pela sociedade globalizada que definitivamente produz consumidores ${ }^{56}$. O consumismo envolve sonho, romantismo, imaginário de realização, uma vez que 'a atividade essencial do consumo não é a seleção, a aquisição ou o uso real dos produtos, mas a procura imaginária do prazer a que se presta a imagem do produto, ${ }^{, 57}$.

No outro lado da mesma moeda do consumismo encontra-se a 'estetização da existência,58. O fascínio exercido pela televisão produz uma sociedade da estética e da aparência, cuja predominância sobre a ética e outros valores é cada vez mais acentuado. Outras áreas, com maior ou menor intensidade, perdem seu valor e autonomia para o reinado da estética, como a teórica, a moral-política, a ética $^{59}$. Outros termos equivalentes denunciam a concretização de uma cultura marcada pelo 'presentismo' dificultando a pergunta pelo sentido da existência: 'apogeo dos simulacros ${ }^{\prime 60}$; cultura da 'intranscedência e do divertimento' ${ }^{61}$.

\subsection{4}

\footnotetext{
${ }^{54}$ AMADO, J. P. Desafios da globalização à vivência e à transmissão da fé. XXI ${ }^{\circ}$ CONGRESSO MUNDIAL DO APOSTOLADO DO MAR. http://www.aos-world.org/library/rio/Rio02pt.pdf.

${ }_{55}$ SANTOS, B. S. A gramática do tempo, op. cit., p. 438.

${ }^{56}$ Cf. BAUDRILLARD, J. À sombra das maiorias silenciosas. São Paulo: Editoras Brasiliense, 1993, pp. 26-27.

57 CAMPBELL, C. The Romantic Ethic and the Spirit of Modern Consumerism. Oxford: Blackwell, 1987, citado por FEATHERSTONE, M: O desmanche da Cultura. São Paulo: Studio Nobel. SESC, 1997, p. 45.

${ }^{58}$ Cf. MARDONES, J. M. En el umbral del mañana. El cristianismo del futuro. Madrid: PPC, 2000, p. 128

${ }^{59}$ Cf. KUMAR, K. Da sociedade pós-industrial á sociedade pós-moderna. Rio de Janeiro: Jorge Zahar, 1997, p. 128.

${ }^{60}$ Cf. BAUDRILLARD, J. Las estratégias fatales. Barcelona: Anagrama, 1984, p. 59.

${ }^{61}$ Cf. VELASCO, J. M. Ser cristiano en una cultura posmoderna, op. cit. p. 57.
} 


\section{A afirmação do urbano: uma nova configuração do tempo e do espaço}

À globalização cultural, social, econômica e religiosa pode-se sem maiores dificuldades associar o fenômeno da urbanização da sociedade contemporânea, outro nome para dizer a mesma realidade cultural em plena transformação. Depreende disso não se poder sem mais confundir a realidade urbana com a cidade, embora o fenômeno urbano hodierno se mova sobre as cidades, dela fazendo uso para se alimentar e para se difundir, transportando-se com muita rapidez para outras localidades físicas, necessário para a sua sobrevivência ${ }^{62}$. Dito diferente, por contexto urbano entende-se as mudanças socioculturais surgidas nas ultimas décadas, presentes em todas as partes do mundo em função dos meios de comunicação e tecnológicas, sobretudo a informática ${ }^{63}$.

Os autores preferem classificar o fenômeno urbano em três etapas, interligados entre si, que dependendo do contexto se percebe a predominância de um sobre os outros: contextos pré-urbanos, urbano-industriais e urbano-pósindustriais ${ }^{64}$. Contextos pré-urbanos são os ambientes pequenos, fechados em si mesmos. A praça é o espaço da dinâmica da vida pública. O tempo transcorre lentamente e o espaço é fixo. Contextos urbanos industrial surgem a partir da revolução industrial, onde a mobilidade e setorização da vida ganham destaques.

Diferencia-se o ambiente da moradia e do trabalho. Diferentemente dos contextos pré-urbanos o individuo alarga seus laços de convívio. Mercantilização, imediatez, economia são conceitos chaves, conforme já explanado anteriormente. Ambientes urbanos pós-industriais dizem respeito a atual revolução social, cujas características estão sendo abordadas desde o início deste capítulo, ultrapassando as fronteiras da cidade, chegando com facilidade em todos os cantos do planeta.

São, sobretudo, as categorias tempo, espaço, participação, mobilidade que melhor traduzem a nova configuração urbana da sociedade, modificando radicalmente a relação do ser humano com o tempo e o espaço. Nas considerações de Bauman, “cancela-se a diferença entre longe e aqui. O espaço não impõe mais

\footnotetext{
${ }^{62}$ Cf. AMADO, J. P. Experiência eclesial em mundo urbano ( $1^{o}$ parte). In: Atualidade Teológica. Revista Semestral do Departamento de Teologia da PUC-Rio. Ano V, n. 8, janeiro/junho, 2001, p. 26.

${ }^{63}$ Cf. IANNI O. A Era do globalismo. Rio de Janeiro: Civilização Brasileira, 1997, pp. 59-85.

${ }^{64}$ Cf. Ibid., p. 24 ss.
} 
limites à ação e seus efeitos. Ele conta pouco, ou nem conta. Perdeu seu valor estratégico" 65 .

Corrobora-se, portanto, o rompimento das fronteiras territoriais. Invadem-se e encurtam-se os espaços em tempo inimaginável. A circularidade, seja ela de informações, idéias ou mesmo de pessoas é algo inédito na história. A autonomia do sujeito em todos os níveis é estimulada, sobretudo no tocante ao território. O mundo urbano extrapola todo e qualquer limite geográfico, modificando a relação entre os grupos naturais, como bairro, família, religião. A urbanização cada vez mais emancipa o individuo da família, da vizinhança, do estado e da Igreja. Entram em cena as relações virtuais as quais encurtam as distâncias geográficas. Não mais regidos pela força da tradição, os espaços e as relações urbanas são determinadas pelo interesse ${ }^{66}$.

Os limites jurídicos não só são ultrapassados com também diversas cidades coexistem dentro de uma mesma cidade. Urge distinguir território geográfico e território sociocultural, pois em condições históricas diferentes, o sujeito constrói sua identidade prescindindo do território ${ }^{67}$. Diferentemente das sociedades tradicionais, a cidade não é mais centrípeta, onde já não há mais centros e sim pluricentros.

É lamentável que subjacente à aceleração do ritmo do tempo está a mentalidade do aproveitamento ao máximo do hoje, cuja conseqüência inevitável é a mentalidade do descartável. Por outro lado, cresce a consciência dos perigos global, cientes de que vivemos da interdependência entre tudo e todos. Ou seja, graças à reformulação do tempo e espaço, tomadas de consciência que até então eram localizadas, ganham agora uma alcance universal.

A intenção do caminho percorrido até aqui foi adentrar na nova casa cultural em construção pela mudança de época. Resta ainda visitar um recinto, certamente central para nossa pesquisa, a saber, o religioso, que de certa forma, explícita ou implicitamente, já foi introduzido na abordagem feita até o momento.

\footnotetext{
${ }^{65}$ BAUMAN, Z. Modernidade líquida, op. cit., p.136.

${ }^{66}$ Cf. LIBANIO, J. B. A Lógica da cidade: o impacto sobre a fé e sob o impacto da fé. Loyola: São Paulo, 2001, p. 32..

${ }^{67}$ Cf. AMADO, J. P. Experiência eclesial em mundo urbano ( $2^{\circ}$ parte). In: Atualidade Teológica. Revista Semestral do Departamento de Teologia da PUC-Rio. Ano V, n. 9, julho/dezembro 2001, p. 161.
} 


\section{4}

\section{Mudança de época e as transformações religiosas}

Qual o impacto da revolução cultural na religião? A atual cultura é fechada à experiência religiosa? A racionalidade moderna conseguiu apagar o fascínio pelo sagrado? Como explicar a atual efervescência de novos movimentos religiosos e espiritualidades, ao mesmo tempo em que crescem o ateísmo e a indiferença religiosa, sobretudo na Europa? O que buscam os homens, hoje, na religião? Pode-se falar de retorno do sagrado? Essas e outras indagações não permitem respostas simplórias, pois entender o fenômeno religioso nos tempos atuais torna-se tão desafiador quanto entender a própria mudança epocal. Em épocas de profundas transformações em todos os níveis, a religião não está imune de metamorfoses, sobretudo porque a vivência da fé nunca é atemporal ou acultural, mas sempre se apresenta condicionada pelo lugar e tempo no qual está inserida, ou conforme já acenamos no início do capítulo, a fé é sempre uma opção existencial encarnada, enraizada em raízes sociais e culturais determinadas ${ }^{68}$. Se mudança de época significa a transformações da totalidade das relações, então a relação entre ser humano e Deus também assume uma nova perspectiva, a qual será analisada nas páginas a seguir. Importa mais uma vez ressaltar que a análise em percurso será determinante para posteriormente estabelecer um diálogo entre iniciação à vida cristã e a instituição paroquial.

\subsection{1}

\section{Uma religiosidade inédita}

Uma genuína 'metamorfose religiosa' traduz o que se passa com o atual fenômeno religioso, somente comparada ao momento histórico denominado por Jaspers de tempo-eixo, através do qual ele se refere às mudanças na consciência religiosa da humanidade, entre os anos 800 a 200 alC, com o surgimento das grandes religiões numa aproximação geográfica (Indica, China, Grécia, Israel) ${ }^{69}$.

Muitas são as expressões utilizadas no meio acadêmico e pastoral na tentativa de entender a religiosidade nos dias atuais. "Retorno do sagrado,

\footnotetext{
${ }^{68}$ Cf. MARDONES, Análises de La sociedad y Fe Cristiana. Madrid: PPC, 1995, pp. 5-6.

${ }^{69}$ Cf. JASPERS, citado por PALÁCIO, C. O cristianismo na América Latina, op. cit. A mesma comparação é citada por VELASCO, M. Neoliberalismo y religión. Estella: Verbo Divino, 1998, pp. 9-12.
} 
'revanche do sagrado', 'religião selvagem' explosão do sagrado', 'religião invisível', 'difusa', 'silvestre', 'believing without belonging', são expressões que apontam por onde caminha a nova relação do ser humano com o sagrado e com as instituições religiosas.

A origem desta religiosidade inédita que se avizinha da pós-modernidade remonta ao nascimento da secularização da sociedade moderna. Em outros termos, as mutações religiosas em voga já vêm de longa data, e o que se assiste hoje é a radicalização da relação com o transcendente, ou nas palavras de Velasco, uma 'segunda secularização, ${ }^{70}$. Para melhor captar a intuição do autor, urge um retrospecto das características da primeira secularização que, sem sombra de dúvidas, estão muitos presentes na sociedade. Por primeira secularização entendese o que é causa e efeito da modernidade, a qual deu à luz as ciências experimentais, ao progresso científico, à dogmatização da razão, entre outros aspectos. No tocante à relação do cultural com o religioso, este é relativizada, já não dita mais as regras do social. Com a emancipação das instituições sociais da tutela religiosa, cada setor da sociedade começa a se organizar autonomamente e a buscar uma explicação racional do mundo, o que não quer dizer que seja anulada a relevância institucional religiosa enquanto portadoras de sentido e do sagrado. São as instituições religiosas que continuam a fornecer as crenças aos fiéis, as normas e os ritos, contudo, cada vez mais perde força na ordenação social ${ }^{71}$.

$\mathrm{Na}$ atual mudança de época, percebe-se que a proposta do endeusamento da razão, levado até as últimas conseqüências pela modernidade, não conseguiu compensar a busca do transcendente inerente a todo ser humano, conforme bem intuiu Rahner com o 'existencial sobrenatural'. Embora não se possa negar a indiferença religiosa e um certo grau de ateísmo nos tempos atuais, a modernidade não conseguiu apagar o fascínio pelo sagrado na agenda do novo milênio. Sobressai hoje, apesar da fragmentação sócio existencial, ou justamente por causa dela, a constante necessidade de buscar um sentido maior para a existência, sentido este que a civilização tecnocientifica.

\footnotetext{
${ }^{70}$ VELASCO, J. M. Ser Cristiano em una cultura posmoderna, op. cit., citado por PALÁCIO, C. O cristianismo na América latina: discernir o presente para preparar o futuro. In: Perspectiva Teológica. Belo Horizonte, v., 36, fasc. 99, maio/agosto 2004, pp. 180-181.

${ }^{71}$ Cf. VELASCO, J. M. Ser Cristiano em una cultura posmoderna, op. cit. p. 59.
} 
O anúncio da morte de Deus cedeu lugar ao surgimento de uma religião 'onipresente', contudo revestida de inéditas cores e formas, corroendo por dentro as próprias instituições religiosas, ou se quisermos, o sistema de crença e pertença. Engana-se quem pensa que o atual interesse pelo sagrado significa volta às instituições, e aqui chegamos na assim chamada 'segunda secularização'.

Com a primeira secularização, religião já não podia sem mais ser identificada com sociedade, e agora religião não pode mais sem mais ser identificada com instituição religiosa. $\mathrm{O}$ novo estatuto religioso rompe com o sistema religioso organizado pelas instituições, surgindo espaço à criação de uma religiosidade própria. Novas sínteses são elaboradas, contraditórias por vezes, cuja ‘identidade’ está na mistura de vários elementos, como a ciência, a filosofia, a gnose, o esoterismo, colocando em cheque os conceitos de religião, mística, transcendente. Com razão afirma Palácio que "a dilatação sem limites do conceito de "religioso" torna cada vez mais impreciso o seu contorno e ambígua a experiência que dele resulta"72.

Enquanto que na modernidade o processo de secularização dizia respeito à emancipação das diversas esferas sociais do domínio do religioso, na pósmodernidade a experiência religiosa liberta-se do domínio das instituições religiosas e das regras pré-estabelecidas para adentrar no consumismo religioso sem precedente na história da religião. Segundo Mardones, "a religiosidade não desaparece, senão que estamos assistindo a uma desistitucionalizaçao da religião. Avançamos para uma religião onde o protagonismo é o indivíduo e não a instituição"73.

\section{4 .2}

\section{Privatização das crenças e a crise das instituições religiosas}

Este título tem a intenção de aprofundar as afirmações acima feitas, pois trata de umas das características religiosas que mais tem impacto no tema de nossa pesquisa, disposta a refletir a relação da iniciação cristã com a instituição eclesial paroquial.

\footnotetext{
${ }^{72}$ PALÁCIO, C. O cristianismo na América Latina, op. cit., p. 180.

${ }^{73}$ Cf. MARDONES, J. M. Adónde va la religión? Santander: Sal e Terrae, 1996, p. 21.
} 
Um dos efeitos mais visíveis das atuais transformações religiosas diz respeito à crise das instituições religiosas. São elas que mais sentem de perto os abalos da atual 'privatização religiosa', da religiosidade móvel, por meio da qual os indivíduos constroem, numa trajetória individual e subjetiva, o próprio edifício religioso.

Surgem a cada dia novas formas de 'pertenças' religiosas que fogem do controle dos grandes sistemas religiosos institucionais. São, sem sombra de dúvida, transformações que visibilizam uma nova etapa cultural religiosa que rompe com a sociedade tradicional, consequientemente com as formas tradicionais de relacionar-se com o sagrado.

Se nas sociedades tradicionais a religião e suas instituições existiam como monopólios de legitimação última da vida individual e coletiva da sociedade, hoje elas perdem plausibilidade e solidez. Já não são mais as instituições religiosas que desempenham a função de transmissão de um código unificador de sentido social. Este é reelaborada individualmente a partir de um vasto mercado de possibilidades de experimentos, sem vínculos duradouros, ou até mesmo ausentes de qualquer sentimento de pertença. As adesões religiosas cada vez menos estão relacionadas à verdade apresentada pela religião, e dizem respeito à capacidade das instituições de oferecerem aos indivíduos algo que vá ao encontro de suas necessidades.

Prevalece o desejo de aceso imediato e direto às experiências religiosas, desejo este que não hesita em experimentar ao máximo as mais diversas possibilidades à disposição, na busca do "self perfeito" ${ }^{74}$. Portanto, a afirmação de uma religiosidade centrada no indivíduo, que hipervaloriza o caminho privado, com insistência na experiência com Deus sem intermédio das instituições provoca o processo de desinstitucionalização ou desregulamentação das identidades religiosas $^{75}$.

As pertenças institucionais que antes congregavam as pessoas, agora têm de enfrentar a angustiante realidade da infidelidade de seus fiéis. A autoridade e o

\footnotetext{
${ }^{74}$ Para uma melhor abordagem da religiosidade individualista pós-moderna, cf. D'ANDREA, A. F. $O$ self perfeito e a nova era: individualismo e reflexividade em religiosidade pós-tradicionais. São Paulo: Loyola, 2000.

${ }_{75}$ Cf. HERVIEU-LÉGER, D. O Peregrino e o convertido: a religião em movimento. Lisboa: Gradiva, 2005, p. 56.
} 
poder, as normas, os dogmas, as leis são submetidas a uma possível adesão pessoal. As instituições se vêem obrigadas a competir não somente entre sim no vasto campo religioso, mas igualmente disputar terreno com outras agências sociais que tentam impor sua legitimação social. Neste contexto, as instituições garantem seu lugar à medida que oferecem os 'bens de consumos' exigidos pela subjetividade dos sujeitos. Exemplos plausíveis, no Brasil, do processo de desinstitucionalização são o alto índice de desfiliações religiosas e o aumento dos sem-religião. Contudo, sem religião, longe de significar não crença num ser superior, ateísmo, aponta para a dinâmica da desfiliação religiosa que caracteriza a religião no momento. Crer sem pertencer parece ser mais uma opção religiosa na plural sociedade pós-moderna.

Importante afirmar ainda que passagem da religião institucional não signifique que as religiões institucionais perderam seu papel na sociedade. Nem tão pouco significa que perderam seu poder de eficácia na vida individual e social. As instituições, assim como a realidade das identidades confessionais continuam a exercer seu papel social, porém dependem agora muito mais da aceitação pessoal dos indivíduos. Os indivíduos continuam buscando nas tradições/instituições a referência e confirmação de suas crenças, mas o fazem a partir de sua subjetividade e numa seletiva escolha daquilo que lhe convém.

\section{4 .3}

\section{Mobilidade religiosa}

A vivência do sagrado se apresenta cada vez mais móvel, solta, itinerante, em perfeita consonância com o espírito líquido descrito por Balmam. Sai de cena a religião estática das sociedades tradicionais que por séculos marcou a religião ocidental, para dar lugar a uma religiosidade em pleno movimento. Há não muito tempo as religiões eram essencialmente estáveis, sobretudo no que tange à organização e à pertença: o crente rigorosamente fiel a sua instituição, os espaços altamente delimitados e definidos, as normas e regras inquestionavelmente aceitas.

Não é difícil perceber que essa cena não tem mais lugar na atual configuração religiosa, ou ao menos não tem o mesmo espaço de antes. Nas sociedades contemporâneas outro espírito se impõe, de tal forma que já não se 
pode mais falar, senão como exceção, de fidelidade institucional, estabilidade geográfica e comportamentos pré-estabelecidos.

Visivelmente está em curso uma religiosidade peregrina, com indivíduos religiosamente nômades. Tornou-se comum na análise sociológica da religião, sobretudo no Brasil, a aplicação do conceito 'trânsito religioso' para exprimir o caráter errante da religião contemporânea. As novas práticas religiosas não se prendem nem ao espaço nem ao tempo, abrem mão de todo e qualquer enquadramento. $\mathrm{O}$ religioso se sente livre para buscar, experimentar e vivenciar o sagrado guiado por sua subjetividade. Assediado pela diversidade religiosa à sua disposição, ele transita livremente, sem qualquer sentimento de culpa, entre as várias opções religiosas existentes na busca da construção de sua identidade sociocultural-religiosa ${ }^{76}$.

Metáforas têm sido utilizadas na tentativa de explicar o que se passa com o sujeito religioso nômade e a religião móvel da cultura atual. Se uma das principais tendências religiosas da atualidade é a necessidade do indivíduo produzir ele mesmo o significado de sua existência, ou se quisermos, sua identidade sócio religiosa, a partir dos recursos simbólicos a sua disposição, o peregrino e o convertido são, na intuição de Hervieu-Léger, as figuras típicas da dinâmica religiosa contemporânea ${ }^{77}$.

O peregrino sugere em primeiro lugar movimento, experimento, busca, procura. Daí ser ele o exemplo cristalino do religioso de nossos dias que se sente na liberdade para transitar entre os vários credos na busca de experiências religiosas gratificantes. A figura do convertido, por sua vez, revela a autenticidade do processo da construção da identidade sócio-religiosa de alguém que deseja construir o próprio universo de significações religiosas. A imagem do convertido pode representar tanto a mudança de uma religião à outra, como também a redescoberta de sua religião de origem. Em ambos os casos, trata-se de uma adesão voluntária.

O quadro comparativo da mesma autora ilustra com clareza a diferenciação dos dois modelos religiosos acima mencionados, o praticante e o peregrino. $\mathrm{O}$

76 Cf. ANTONIAZZI, A. Perspectivas pastorais a partir da pesquisa. In: SOUZA, L. A; FERNANDES, S. R. A (orgs.). Desafios do catolicismo na cidade: pesquisa em regiões metropolitanas brasileiras. CERIS. São Paulo: Paulus, 2002, p. 253.

${ }^{77}$ HERVIEU-LÉGER, D. O Peregrino e o convertido, op. cit., p. 119. 
praticante: prática obrigatória, fixa, comunitária, territorialmente delimitada (estável), ordinária, costumeira, repetida. O peregrino: voluntária, autônoma, moldável, individual, desterritorializada, móvel, extraordinária, excepcional, ocasional $^{78}$. Portanto, a figura exemplar do praticante regular e fiel deixa de ser o padrão de referência do cenário religioso contemporâneo. A dinâmica da conformidade e obrigatoriedade cede lugar a práticas voluntárias descompromissadas, conforme revela o depoimento de um jovem: "Sou católico, vou à missa aos domingos. Bem, nem sempre: há alturas em que não tenho vontade, isso não me diz nada"79.

Trata-se, enfim, de um jeito fluido, livre e espontâneo de lidar com a religião, o que nem sempre é fácil de compreender, uma vez que por séculos a religião foi marcada por uma realidade estática. No âmbito do catolicismo, é a 'civilização paroquial' a representante da religiosidade fixa e regular. Conclui-se que hoje, em tempos de mobilidade social e religiosa parece ser evidente a crise paroquial.

\section{4 .4}

\section{Crise da transmissão religiosa e o imperativo da escolha}

A crise das grandes tradições e instituições religiosas anteriormente descrita se reflete de maneira impar na dificuldade da transmissão religiosa de uma geração à outra. Há um tempo não muito longínquo a comunicação religiosa às gerações futuras era garantida pela tradição, via de regra, transmitida pelas instituições religiosas, pela família e pela própria cultura. No Brasil, especificamente por cinco séculos a religião, no caso o catolicismo, perpetuou-se entre as gerações através da força da tradição. $O$ atual universo religioso, fragmentado e privado, não nos permite mais pensar a religião a partir da herança tradicional.

A religião professada hoje cada vez menos é aquele na qual se nasce. Crença hoje é matéria de opção. Foi P. Berger quem bem intuiu tal dinâmica com seu clássico termo 'imperativo herético'. Heresia, em seu sentido original, significa escolha. Escolher a própria religião tornar-se hoje um imperativo, uma

\footnotetext{
${ }^{78}$ Ibid., p. 109.

${ }^{79}$ Ibid., p. 96.
} 
necessidade e uma obrigação ${ }^{80}$. O exemplo citado pelo sociólogo da religião L. Benedetti traduz de forma lapidar o atual imperativo herético religioso.

Numa família de 13 pessoas, a família Rodrigues, havia treze religiões diferentes. Sem contar três que, batizada na católica, declaravam-se sem religião. Das 13 só uma ainda pertence à Igreja em que foi batizada. Assim, Aparecido (nome fictício) passou por cinco grupos religiosos diferentes. Fixou-se no sexto, a Igreja Batista ${ }^{81}$.

O 'sagrado', até então ancorado nas tradições religiosas passa a ser assunto que diz respeito à síntese pessoal realizada pelo crente. A estrutura do crer não é mais assunto exclusivo das tradições religiosas, mas construída pelos indivíduos, que se apropriam das várias e pequenas estruturas do crer à sua disposição.

Uma melhor compreensão a respeito da crise das tradições deve ser buscada na crise da memória, típica das sociedades pós-modernas. As sociedades póstradicionais não apenas não são mais sociedades de memória como também recusam um passado fundador. Vivemos numa sociedade 'amnésica', na expressão de Hervieu-Léger ${ }^{82}$. Na mesma dinâmica da desistitucionalização, visto anteriormente, as referências de memória se diluem facilmente e em seu lugar se impõem memórias plurais, fragmentadas e imediatistas.

As religiões participam diretamente do dilema da crise de memória. A dinâmica religiosa hodierna oferece ao indivíduo uma oportunidade inédita de arquitetar por conta própria o próprio universo de valores, crenças, práticas e sua estrutura de crença, prescindindo das memórias originárias e fundantes. Outros valores, tais como a emotividade e o imediatismo, congregam mais do que a memória coletiva e celebrativa.

São os jovens nascidos a partir dos anos 70 que mais querem se libertar da religião institucional/tradicional para vivenciar novas experiências, fazer sínteses pessoais para além dos vínculos institucionais. As adesões são voluntárias, após uma peregrinação pelas mais diversas possibilidades. O acento religioso no mundo urbano se desloca da tradição para o individuo, das normas para a subjetividade, da herança adquirida para a escolha. Se batem à porta da tradição, o fazem a partir de uma afinidade pessoal sentida por ela e pelos benefícios que ela

\footnotetext{
${ }^{80}$ Cf. BERGER, P., citado por D'ANDREA, A. O self perfeito e a nova era, op. cit., p. 26.

${ }^{81}$ BENEDETTI L. R. Religião: trânsito ou indiferenciação. In: TEIXEIRA, F.; MENEZES R. (orgs.). As religiões no Brasil: continuidades e rupturas. Petrópolis: Vozes, 2006, p. 125.

82 Cf. HERVIEU-LÉGER, D. O Peregrino e o convertido, op. cit., p.70.
} 
pode oferecer. Já não se sente necessidade de prestar contas a uma tradição religiosa, ou seja, na atualidade se é religioso sem a necessidade de uma religião.

Enfim, o sagrado está no palco da história, porém, reconfigurado. Individualismo, subjetividade, mobilidade, do enfraquecimento da memória coletiva e das instituições são não apenas algumas das características socioculturais como também aspectos preponderantes na atual sensibilidade religiosa secularizada.

Importa perceber que o quadro cultural e religioso acima tem incidência direta no assunto de nossa pesquisa, a iniciação à vida cristã e a configuração paroquial. As duas realidades são diretamente afetadas pela mudança de época. A primeira, em síntese, pelo vies da crise do que chamamos crise da transmissão religiosa, e o segundo, pela assim denominado crise das instituições religiosas.

\section{5}

\section{Crise do cristianismo ou possibilidade de uma nova configuração?}

As páginas precedentes ilustraram o atual fenômeno cultural e religioso, apontando para a nova relação entre cultura e religião. Um passo além sugere um olhar mais teológico voltado ao cristianismo, ou mais especificamente à fé cristã. Se até aqui nos ativemos a um olhar mais abrangente, isto é, as influências do cultural nas religiões em geral, oportuno agora se torna uma dedicação maior às possibilidades e desafios à fé cristã.

\subsection{1}

\section{A fé cristã e os desafios da mudança de época: um olhar teológico}

Os ventos da nova cultura socioreligiosa abalaram profundamente as religiões tradicionais, desde as minoritárias até as majoritárias, afetando sua configuração institucional e abrindo as portas para um novo jeito de lidar com o sagrado. Entretanto, é o cristianismo e sua vertente católica a instância mais atingida pela revolução em percurso, primeiramente por ser a religião preponderante, senão exclusiva durante séculos e milênios em determinados ambientes. Em segundo lugar, é o cristianismo, dada sua trajetória histórica, uma das religiões mais institucionalizadas, sendo essas as que mais sentem o impacto da 'metamorfose religiosa'. 
Se até o momento abordamos o fenômeno religioso através do sociológico, imprescindível agora se torna um olhar teológico, isto é, uma reflexão à luz da fé cristã, atentos aos desafios e às possibilidades ao cristianismo no terceiro milênio. Por fidelidade à missão teológica e pastoral, que quer ser um serviço de discernimento, urge fornecer marcos críticos teológicos para que a mensagem cristã, vale dizer, a proposta salvífica de Jesus Cristo seja transmitida, acolhida e vivida sem deturpações numa cultura marcada por resignificações religiosas. Em outras palavras, há de se reconhecer a ambivalência de toda realidade sócio cultural. Conforme já afirmado, positivo e negativo compõem o cenário de toda e qualquer contexto histórico. Resulta daí a tarefa imprescindível do olhar teológico que pretende questionar as tendências ameaçadoras à experiência religiosa bem como reconhecer as possibilidades do novo contexto para a vivência e transmissão da fé.

Se a teologia dos sinais dos tempos nos convida a descobrir a ação do Espírito na história, há de reconhecer as contribuições do novo contexto à transmissão e à vivência da fé cristã, dentre as quais se destacam a tolerância religiosa, o menos dogmatismo, a valorização da experiência, a abertura ao simbólico ${ }^{83}$. Urge ainda chamar a atenção para a positividade de uma fé cristã fruto da opção pessoal e da decisão livre, desde que esteja em coerência com a mensagem do Evangelho.

Afirmar o sopro do Espírito na nova realidade não significa a ausência de equívocos na mesma. É sempre oportuno relembrar que o Espírito nunca age num vazio histórico, o que significa afirmar que toda e qualquer realidade impregnada da ação do Espírito está sujeita a não captar de modo pleno o seu agir. Portanto, na tarefa de distinguir o que é ação do Espírito e o que é produto cultural, fundamental se torna olhar o atual 'interesse pelo sagrado' com cautela. Nesta perspectiva, preocupante é a acentuada transformação de sentido de dimensões fundamentais do encontro entre Deus e ser humano. Conceitos como religião, fé, revelação, experiência de Deus sofrem mutações substanciais. Mais do que modificações acidentais, é o sentido mesmo da religião que parece passar por profundas transformações.

\footnotetext{
${ }^{83}$ Cf. MARDONES, J. M. Análisis de la sociedad y fe cristiana, op. cit., p. 84.
} 
O cerne a ser questionado está na experiência de Deus, conforme a entende a tradição cristã. Por fidelidade ao dado da Revelação, não se pode omitir a pergunta pela possibilidade mesma de se fazer uma autêntica experiência de Deus numa cultura marcada pela imanência. $\mathrm{O}$ que se assiste hoje no assim chamado 'retorno do sagrado', tende ao encontro com o transcendente ou trata-se de um mergulho na própria interioridade? No momento mesmo em que se confessa a fé em Deus, inicia-se um êxodo, uma saída do próprio ego para se fundamentar no outro, no grande Outro.

Contra uma tendência bastante acentuada em confundir a experiência de Deus com outras experiências antropológicas, cuja tônica está nas sensações corporais e psicológicas, se posicionam algumas vozes teológicas respeitadas. Segundo França Miranda, "a experiência de fé não é, portanto, apenas uma experiência do Sagrado, mas uma experiência do Sentido"84. Não poucos, motivados por uma mentalidade individualista, buscam na religião aquilo que a cultura atual não lhe fornece ${ }^{85}$.

A experiência religiosa somente tem sentido se for construída a partir da dinâmica relacional de acolhida abertura ao dom, não a partir do consumo egocêntrico. A experiência religiosa não se esgota nas experiências de proteção, na lógica da satisfação imediata das necessidades das mais diversas ordens, psicológica, física, econômica. Daí se entende o sucesso das denominações que mais oferecem proteção, cura divina, prosperidade. Por ser a mensagem do Evangelho uma proposta de salvação, quando esta é reelaborada a partir do individualismo sem correspondência na práxis e na abertura ao outro e a Deus, coloca-se em risco a própria proposta salvífica. Neste caso, é a identidade cristã mesma que está comprometida, uma vez que a revelação cristã não se coaduna com a tentação de fabricar Deus à própria imagem, ou na insistência da composição de um rosto de Deus, fruto da mistura de vários elementos, cujo resultado é um transcendente sem fisionomia, uma 'nebulosa místico-esotérica'. Percebe-se o iato criado entre a atual configuração religiosa e a proposta fundante do cristianismo, para o qual é demasiado claro que fé é uma resposta gratuitamente a uma proposta igualmente gratuita de Deus; é reconhecimento do

${ }^{84}$ VAZ, H. L. A experiência de Deus. In: BETTO, F. et alli. Experimentar Deus hoje. Petrópolis: Vozes, 1976, p.

${ }^{85}$ Cf. MIRANDA, M. F. Um Homem perplexo, op. cit., p. 36. 
Absoluto, de uma realidade anterior a nós mesmos que provoca uma ruptura existencial.

A nova cultura religiosa visivelmente provoca uma ruptura entre fé-vida, tão caro à fé cristã. Os conteúdos de fé, os ritos, as práticas religiosas desenraizadas da vida revelam um deslocamento da transcendência para esta vida ${ }^{86}$. Os sacramentos não raramente são buscados com fins terapêuticos, na busca de proteção individual e não como canal de graça e relacionamento com Deus e com os irmãos, como dom acolhedor da Revelação. Salvação é proposta divina que requer resposta humana, e esta implica mudança de mentalidade e de valores ${ }^{87}$. O cristianismo nasceu da experiência salvífica dos discípulos com seu mestre, que levou a uma resposta de fé, e a testemunhar em atitudes e palavras esta experiência. A experiência salvifica é acolhia do Dom imanipulável que conduz à abertura ao outro, à pratica do amor e da caridade ${ }^{88}$.

Não menos preocupante é a atual distância entre experiência de Deus e experiência eclesial. A atual dissociação entre experiência de Deus-experiência eclesial constitui não apenas uma distorção do Evangelho como inviabiliza ao extremo qualquer tentativa de iniciação cristã. Estamos lindando, portanto, com um problema crucial que toca a identidade da fé cristã, cuja resolução permanece um desafio pastoral premente.

O cristianismo por fidelidade a sua origem sempre denunciou as tendências de uma 'fé-evento'. Os Documentos conciliares reafirmam a beleza de fazer a experiência de Deus em uma comunidade concreta. Como Deus não criou os homens para viverem isoladamente, mas formarem uma união social ... Deus escolheu os homens não como indivíduos somente, mas como membros de uma comunidade" (GS 32) $)^{89}$.

A pertença a uma comunidade eclesial ainda que esta pode ser concretizada sob diversas formas e a partir de novos pressupostos, é intrínseca à profissão de fé. O Documento de Aparecida nos recorda que a fé cristã é sempre mediatizada

\footnotetext{
${ }^{86}$ MIRANDA, M. F. Um Catolicismo Desafiado, op. cit., p. 14.

${ }^{87}$ Cf. PAULO VI. Exortação Apostólica Evangelii Nuntiandi. A evangelização no Mundo Contemporâneo. São Paulo: Paulinas, 1977, n. 18.

${ }^{88}$ AMADO. J. P. Experiência Eclesial em Mundo Urbano: pressupostos e concretizações $\left(1^{\circ}\right.$ parte), op. cit. In: Atualidade Teológica. Revista Semestral do Departamento de Teologia da PUCRio. Ano V, v. 8, op. cit., p; 25.

${ }^{89}$ CONCÍLIO VATICANO II. Constituição pastoral Gaudium et Spes sobre a Igreja no mundo de hoje. Documentos do Vaticano II, 1965. Petrópolis: Vozes, 1966.
} 
pela Igreja. "Diante da tentação, muito presente na cultura atual, de ser cristão sem Igreja e das novas buscas espirituais individualizadas, afirmamos que a fé em Jesus Cristo nos chega através da comunidade eclesial” (DA 256). O mesmo Documento recorda que "a vida em comunidade é essencial à vocação cristã" (DA 179).

Importa perceber que subjacente as questões levantadas está a pergunta pela salvação. A mensagem cristã confessa que salvação não pode ser um caminho construído pelo próprio fiel, à margem da Tradição cristã. A acolhida parcial da verdade revelada fazendo das motivações pessoais o critério supremo da práxis cristã, significa uma redução do Evangelho ${ }^{90}$. O processo seletivo de elementos religiosos e crenças, a bricolagem e a ressignificação incidem no não acolhimento integral da Revelação, processo este que teima em pôr Deus a serviço do humano, na busca da satisfação pessoal e do consumo religioso ${ }^{91}$.

\section{5 .2}

\section{Cristianismo e mudança de época: uma ruptura que exige novas posturas}

Há quem diga estarmos num mundo pós-cristão. Independente da precisão do termo, não se nega que se instaurou uma ruptura entre cristianismo e cultura ocidental. A equivalência ser cristão e ser cidadão, em voga desde a cristandade medieval, vem sendo desfeita desde os tempos modernos. Karl Ranher, já na década de 60 apontava para a situação de diáspora do cristianismo. De lá para cá, o que se vê é a concretização sem volta do 'cristianismo de decisão pessoal' que substitui em passos largos o cristianismo sociológico.

É importante salientar que a assim chamada crise do cristianismo parece indicar muito mais o fim de uma forma histórica do cristianismo, resultado de uma encarnação histórica, vigente ao longo da cristandade, do que o fim do cristianismo em si, haja vista o seu crescimento sobretudo na América latina e África. Tudo indica ser o fim do modelo de cristianismo, homogêneo, cultural,

\footnotetext{
${ }^{90}$ Cf. MIRANDA, M. F. Salvação ou Salvações? A salvação cristã num contexto inter-religioso. In: Revista Eclesiástica Brasileira. Petrópolis: Vozes, v. 58, fasc. 229, janeiro/abril, 1998, pp. 136163.

${ }^{91}$ Cf. AMADO. J. P. Experiência Eclesial em Mundo Urbano, ( $1^{\circ}$ parte $)$, op. cit. In: In: Atualidade Teológica. Revista Semestral do Departamento de Teologia da PUC-Rio. Ano V, v. 8, op. cit., p. 24.
} 
'pré-moderno"92, que teima em continuar vivo apesar da já demonstrada falta de espaço para este tipo de configuração religiosa na nova agenda cultural. Boa parte do sistema de mediações religiosas, ou seja, linguagem, modelo institucional, certas tradições e práticas já não respondem ás necessidades do ser humano que caminha nas novas trilhas culturais.

O cristianismo atravessa, portanto, uma crise de fé concomitante a um processo de desconstrução do modelo tradicional de ser cristão, ou mais diretamente, chegou o fim da cristandade, cujo maior desafio eclesial está, antes de qualquer outro empreendimento, no reconhecimento de tal irreversível ruptura social, a qual é altamente positivo segundo Palácio, pois 'liberta o cristianismo da tentação de identificar-se com uma cultura, no caso a ocidental, e lhe abre condições para que o cristianismo possa ser, de fato, universal ${ }^{93}$. No coração da fé cristã está a convicção de que o cristianismo tem algo a oferecer a todas as culturas sendo que nenhuma delas esgota a riqueza de sua mensagem. A partir da efetiva tomada de consciência da afirmação de uma cultura pós-cristã, grande tarefa é apresentada ao cristianismo, de cujo fracasso ou sucesso dependerá o futuro da pertinência da mensagem cristã aos novos tempos.

A missão crucial imposta ao cristianismo hoje somente é comparada aos primórdios, quando teve ele que fazer a passagem do contexto cultural e religioso do judaísmo para o mundo helênico. Nesta época, a diferença cultural obrigou o cristianismo a reformular sua mensagem e suas expressões de fé de acordo com o horizonte cultural do mundo helênico, afim de que a Boa Nova fosse acolhida e lhe fosse significativa ${ }^{94}$.

\footnotetext{
${ }^{92}$ Cf. QUEITURA, A. T. Fim do cristianismo pré-moderno, op. cit.

${ }^{93}$ PALÁCIO, C. O cristianismo na América Latina, op. cit., p. 184.

${ }^{94}$ Ibid., p. 184.
} 


\section{INICIAÇÃO À VIDA CRISTÃ: IDENTIDADE, TEOLOGIA E PASTORAL}

Iniciamos o segundo capítulo reafirmando o que já foi por nós anunciado: a iniciação cristã constitui um dos maiores desafios pastorais da atualidade. Ela participa do dilema dos grandes sistemas de transmissão de valores da sociedade atual. São responsáveis pelas dificuldades em iniciar na fé aspectos sócio culturais, como vimos ao longo de todo o primeiro capítulo, mas igualmente aspectos internos à própria dinâmica da transmissão da fé. Por séculos predominou o modelo tradicional de catequese, insustentável hoje. Por outro lado, assistimos ao surgimento de um novo paradigma de iniciar na fé, com novos pressupostos, renovadas metodologias, novos acenos, com clareza da identidade teológica da iniciação cristã, entre outras dimensões. São algumas das questões que nos propomos a refletir nos tópicos seguintes.

\section{1}

\section{Da passagem da catequese tradicional ao renovado compromisso com a iniciação à vida cristã}

A história da evangelização tem registrado momentos de intensa vitalidade mas também período de radical estagnação no tocante à iniciação à vida cristã. Nos primeiros séculos da era cristã, o anúncio da Boa Nova, a transmissão da fé aos novos cristãos foi marcada por um impulso único na história do cristianismo. Os cristãos, mesmo constituindo uma parcela inexpressiva numericamente, ora perseguidos ora tolerados pelo império romano, conseguiam atrair, através do testemunho de vida e auxiliados por uma exímia pedagogia iniciática, novos simpatizantes ao cristianismo, aos quais eram oferecida uma autêntica caminhada de aprofundamento na fé.

Com a oficialização do cristianismo, cuja consequência maior foi a adesão em massa à fé cristã, muitos dos quais motivados por outros interesses ${ }^{95}$, entra em

\footnotetext{
95 Os benefícios do império romano enfraqueceram a disposição para abraçar a fé; os sacramentos são conferidos sem critérios, já não sendo mais a conversão de vida uma exigência fundamental para ser batizado. "Uma ingente multidão de pessoas solicita sua entrada na comunidade cristã. Mas os motivos dessa decisão com freqüência são interesseiros e alheios a um desejo de conversão à fé cristã". BASURKO, X; GOENAGA, J. A vida litúrgico-sacramental da Igreja em sua
} 
crise a iniciação cristã, ou mais especificamente, o caminho privilegiado de iniciar na fé denominado catecumenato ${ }^{96}$, que ficará esquecido na Igreja praticamente até o Concílio Vaticano II.

Durante o extenso período de cristandade ${ }^{97}$, vigorou o assim chamado 'catecumenato social', através do qual a sociedade se encarregava de 'transmitir' a fé às novas gerações por meio dos pilares sociais e culturais. Eis porque a iniciação cristã não apresentava maiores preocupações no decorrer destes séculos. Em outras palavras, numa sociedade onde o cultural e religioso se identificavam, a preocupação eclesial com a transmissão da fé não estava entre as principais questões pastorais, pois vale lembrar que neste contexto era lógico ser cristão, ou nascer cristão. O kerigma, primeiro anúncio da Boa Nova, já não era mais imprescindível, restando à ação eclesial apenas o segundo momento, ou seja, a catequese propriamente dita, nas suas funções de ensino, doutrinação, transmissão de conteúdos e administração dos sacramentos.

Portanto, do extenso e rico processo de iniciação cristã dos primeiros séculos, restou, a partir da identificação do cultural com o religioso, as dimensões do ensino, e essa se tornando cada vez mais enrijecida, de cunho moralista e sacramentalista, muito mais centrada na distribuição dos sacramentos do que na iniciação no mistério de Cristo, a qual conseqüentemente culmina e conduz aos sacramentos, conforme bem recorda o Diretório Nacional de Catequese:

evolução histórica. In: BOROBIO, D. (org). A celebração na Igreja 1: liturgia e sacramentologia fundamental. São Paulo: Loyola, 1990, p. 73.

${ }^{96}$ No terceiro capítulo conheceremos a dinâmica do processo de iniciação cristã catecumenal, com todas as suas etapas e ritos. É importante aqui a observação de Luiz Alves Lima para termos uma primeira compreensão do assunto: "O complexo processo que, desde o século II, prevaleceu na Igreja para iniciar os novos membros nos mistérios da fé, recebeu o nome de catecumenato. Para alguns autores esse nome deveria significar apenas o 'segundo tempo' da iniciação cristã, o mais longo e mais propriamente catequético. Entretanto, a maioria usa o termo 'catecumenato' para significar todo o processo da iniciação cristã". No terceiro capítulo veremos como se dá esse processo de iniciação, chamado catecumenato, com todas as suas etapas e ritos. LIMA, L. A. Catequese a serviço da iniciação cristã: reflexões em torno do tema central da $3^{a}$ Semana Brasileira de Catequese. In: Revista de Catequese. São Paulo: Unisal, outubro/dezembro, 2009, ano 32, n. 128, op. cit., p. 16.

${ }^{97}$ Denomina-se cristandade o período histórico no qual poderes civis e religiosos se fundiam e se beneficiam mutuamente. Cultura e religião formavam uma realidade muito semelhante. Não é nosso objetivo aprofundar aqui o período da cristandade nem apresentar um estudo detalhado da história da evangelização. Para isso a bibliografia é vasta. O que queremos é chamar a atenção para a herança recebida, e com resquícios ainda em alguns ambientes, de uma catequese entendida como doutrinação, típica deste período da história. Cf. entre as principais obras, o artigo de LELO, A. F. A iniciação cristã no Brasil. In: Revista de Catequese. São Paulo: Unisal, ano 27, n. 107, julho/setembro, 2004, pp. 5-18. 
A catequese não prepara simplesmente para este ou aquele sacramento. $\mathrm{O}$ sacramento é uma conseqüência de uma adesão à proposta do Reino, vivida na Igreja. Nosso processo de crescimento da fé é permanente; os sacramentos alimentam esse processo e têm conseqüências na vida ${ }^{98}$.

$\mathrm{Na}$ escolástica medieval, a iniciação cristã passou a significar com tons ainda mais fortes a transmissão de noções elaboradas. É a era do catecismo, da moral e da doutrinação. Vale lembrar que o Concílio de Trento, alicerçado na sociedade tradicional, cuidou para que fosse redigido o catecismo dos Párocos (1566), que consiste numa síntese doutrinal, modelo para todos os catecismos redigidos nos séculos seguintes ${ }^{99}$.

$\mathrm{Na}$ Idade moderna, intensificou-se o período de memorização catequética. A consequiência mais drástica da consolidação deste paradigma catequético conceitual-doutrinal pode-se visualizar com facilidade: uma multidão de batizados mas não iniciados. A observação de Floristán traduz a lamentável realidade: "Na Igreja primitiva era batizado o convertido; agora tem que se converter o batizado" 100 .

Importa perceber que este modelo de catequese se enquadra pacificamente no modelo de paróquia denominado 'cura animarum', cujo significado será melhor explicitado quando entramos na configuração paroquial. "Esta catequese e este dispositivo de iniciação eram harmoniosamente inseridos em um tipo de paróquia que temos definido de "cura animarum""101. Uma série de serviços religiosos, pregação, catecismo para os sacramentos, a doutrina cristã, a devoção, as peregrinações eram assim garantido pela paróquia acima denominada. Contudo, são atos religiosos para pessoas já crentes ${ }^{102}$. Igualmente válida é a indagação de um dos maiores especialistas do Brasil em iniciação à vida cristã. Luiz Alves de Lima indiga se toda a ação pastoral-litúrgica, os gestos sacramentais são, de fato, tranmissão de fé e mergulho no mistério? Ou insistimos

${ }^{98}$ CONFERÊNCIA NACIONAL DOS BISPOS DO BRASIL. Diretório Nacional de Catequese. Texto aprovado pela $43^{\text {a }}$ Assembléia Geral, em Itaici - Indaiatuba (SP), 9 a 17 de agosto de 2005, $2^{\mathrm{a}}$ Ed. São Paulo: Paulinas, 2006, (Documentos da CNBB, n. 84), n. 50.

${ }^{99}$ Cf. GRUEN, W. Novos sinais dos tempos para o cultivo da fé. In: Perspectiva Teológica, v. 36, n. 100,2004 , p. 383.

${ }^{100}$ FLORISTÁN, C. Catecumenato: história e pastoral da iniciação. Petrópolis. Vozes, 1995.

${ }^{101}$ BIEMMI, E. Catequesi e iniziazione Cristiana. Uma sfida complessa. In: La rivista del clero italiano. Mensile di aggiornamento pastorale e cultura religiosa dell'Università Cattolica. Gennaio 2012, anno XCIII, p. 53.

${ }^{102}$ Ibid., p. 53. 
num mal entendio 'ex opere operato', que gera uma multidão de batizados não evangelizados ${ }^{103}$ ?

Fato é que o modelo tradicional de iniciação cristã foi configurada para uma sociedade cristã. Os tempos mudaram radicalmente, conforme nos acenou o primeiro capítulo. O tempo da cristandade é substituído pela era pós-cristã. Se antes era lógico ser cristão, numa espécie de herança religiosa, agora vale o inverso, realidade idêntica à origem do cristianismo. A frase de Tertuliano se faz atual: 'cristão não nasce, se torna' (Apologética, 18, 4), daí a necessidade de um autêntico processo de evangelização, centrado no querigma. Não nos é difícil perceber, portanto, o porquê do compromisso irrenunciável da Igreja com a iniciação à vida cristã. A transmissão da fé está nos primeiro plano das preocupações da Igreja e das comunidades cristãs. O motivo dessa preocupação se deve à grave crise que atravessa essa transmissão da fé, presente na maior parte dos países ocidentais de tradição cristã ${ }^{104}$.

Engana-se, contudo, quem pensa bastar a mera vontade em trabalhar em prol da iniciação à vida cristã, por mais autêntico desejo que possa haver. Em tempos de profunda crise cultural e religiosa, vinho novo em odres velhos já não se sustenta. Faz-se necessário um novo paradigma de transmissão da fé, já em andamento desde o Concílio Vaticano II. O que não se pode é sem mais acusar a cultura dominante como responsável única pela crise na transmissão da fé, bem percebido pela Conferência de Aparecida. Fato é que não se pode negar que a Igreja está em busca de um novo modelo de iniciação cristã ${ }^{105}$ : um paradigma que mais do que 'nutrir a fé, se responsabilize também por propô-la ${ }^{106}$. Vejamos a seguir os principais momentos que colocaram em andamento um novo paradigma de iniciação à vida cristã.

\section{2}

\section{Os primeiros passos do novo paradigma de iniciação cristã}

\footnotetext{
103 LIMA, L. A. VII Assembléia ordinária de SCALA. Iniciação à vida cristã: paradigma de transmissão da fé, op. cit., p. 1.

104 VELASCO, J. M. La transmisión de la fe en la sociedade contemporânea. Santander: Sal Terrae, 2002, p. 7.

${ }^{105}$ Cf. LIMA, L. A. Iniciação à vida cristã: paradigma de transmissão da fé, op. cit., p. 12.

106 BIEMMI, E. La dimensione missionária della catechesi: Il convegno ECC nel cuore della problemática del primo annuncio. Catechesi, v. 78, n. 3, 2008-2009, pp.2-8.
} 
Fiel ao compromisso de transmitir a fé que recebeu, a Igreja tem buscado dar respostas pastorais aos desafios que lhe são apresentados. O tema da iniciação à vida cristã está no eixo das atuais prioridades missionárias da Igreja. Expressões como 'nova evangelização ${ }^{107}$, 'missão continental' 'Igreja em estado permanente de missão', 'conversão pastoral' deixam transparecer os esforços em rever o processo de iniciar na fé numa sociedade cujos pilares já não garantem a adesão religiosa. Pode- se dizer que é aguda a atual consciência de que não se chega a ser cristão apenas com o rito do batismo ${ }^{108}$. Graças a esta consciência, novos caminhos e projetos pastorais começam a ganhar corpo. Não obstante nosso foco principal ser o catecumenato, como caminho mais adequando para iniciar na fé, não se pode prescindir de toda uma concomitante caminhada pastoral que está possibilitando a afirmação de uma nova pedagogia e novos pressupostos em vista da formação de uma fé adulta.

Se o tema da iniciação cristã, tão bem enfatizado e recomendado em vários documentos eclesiais não é novo na ação pastoral ${ }^{109}$, é a partir dos anos 50 que cresce a consciência da urgente necessidade de rever o tradicional paradigma de transmissão da fé, rompendo de vez com o estigma de ser o cristianismo uma religião de muitos batizados mas de poucos iniciados na fé ${ }^{110}$.

\footnotetext{
107 'Nova Evangelização' foi o grande lema do pontificado de João Paulo II. Cf. JOÃO PAULO II. Carta Encíclica Redemptoris Missio. São Paulo: Paulinas, 1991, n. 33-34; JOÃO PAULO II. Exortação Apostólica Christifideles Laici. Sobre a vocação e missão dos leigos na Igreja e no mundo. São Paulo: Paulinas, 1988, n. 34. O tema também se encontra no Documento de Santo Domingo, n. 23-30; 129-131. Cf. CELAM. IV Conferência Geral do Episcopado Latinoamericano. Nova Evangelização, Promoção Humana, Cultura Cristã - Jesus Cristo, ontem, hoje e sempre. Documento de Santo Domingo. São Paulo: Loyola, 1993. A mesma intuição já fora captada por Paulo VI na Evangelii Nuntiandi, n. 52. PAULO VI. Exortação Apostólica Evangelii Nuntiandi. A evangelização no Mundo Contemporâneo. São Paulo: Paulinas, 1977.

${ }^{108}$ Cf. BOROBIO, D. Catecumenato para la evangelización. San Pablo, 1997, p. 9.

${ }^{109} \mathrm{Na}$ prática pastoral o termo iniciação cristã é relativamente recente, aparecendo pela primeira vez na publicação do Ritual de Iniciação Cristã de Adultos, em sua primeira edição em 1973. A partir do século XIX a expressão começou a ser utilizada para designar os sacramentos do batismo, eucaristia e confirmação. Percebe-se que a expressão foi assumida pelo Vaticano II, conforme consta em Sacrosanctum Concilium, 71. CONCÍLIO VATICANO II. Constituição Sacrosanctum Concilium sobre a Sagrada Liturgia. In: Compêndio do Vaticano II. Constituições, Decretos, Declarações. Petrópolis, Vozes, 1997 (pp. 259-306); Ad Gentes 14. CONCILÍO VATICANO II. Decreto Ad Gentes sobre a Atividade Missionária da Igreja. 1965. Petrópolis: Vozes, 1966; Presbiterorum Ordinis, 2. CONCÍLIO VATICANO II. Decreto Presbyterorum Ordinis. 4. ed. São Paulo: Paulus, 1965.

${ }^{110}$ Seria longo demais percorrer a caminhada da Igreja nos últimos 50 anos no tocante à iniciação cristã. Queremos chamar a atenção para alguns momentos fundamentais, no Brasil e no mundo, da gestão do novo paradigma catequético.
} 
O ponto de partido de uma nova consciência do processo iniciático está no chamado 'movimento catequético ${ }^{111}$, contudo é a partir do Concílio Vaticano II que se pode genuinamente falar do impulso renovador catequético, muito embora o Concílio não tenha abordado explicitamente o tema. Expressões como 'catequese evangelizadora', catequese missionária', catequese iniciática, as quais apontam para a substituição do paradigma de iniciação pautada na sacramentalização e doutrinação pela busca de uma pedagogia centrada no existencial e vivencial não seriam realidades sem os ares do aggiornamento do último Concílio ecumênico.

Contribuição incalculável trouxe a já mencionada Exortação Apostólica de Paulo VI de 1975 sobre a Evangelização, intitulada Evangelii Nuntiandi: A evangelização no mundo contemporâneo, cuja densidade catequética é muito acentuada. Outros marcos fundamentais no pós-Concílio sobre a iniciação cristã foram o Sínodo dos bispos sobre catequese em 1977 e a Exortação Apostólica Catechesi Tradendae de 1979 ${ }^{112}$. Em 1977, Paulo VI convoca um Sínodo sobre a catequese, que teve enorme repercussão no continente latino americano e como resultado mais direto a publicação da Catechesi Tradendae ${ }^{113}$. Nesta Exortação, João Paulo II coloca a catequese também dentro da complexa e rica dinâmica evangelizadora. Trata-se do primeiro documento pontifício dedicado integralmente à catequese. Segundo a Exortação, “catequese é a educação da fé das crianças, jovens e adultos que compreende especificamente um ensino de modo orgânico e sistemático, com a finalidade de iniciá-los na plenitude da vida cristã" (CT 18). O novo Diretório Geral para a Catequese é publicado em 1997.

\footnotetext{
111 'Movimento catequético' são as iniciativas de renovação e incremento, estímulos e diretrizes na catequese que floresceu no final do século XIX. A partir do incentivo de Roma, o movimento de renovação encontrou em vários países terreno fértil para desenvolver-se. Cf. OLIVERIA, R. M. $O$ movimento catequético no Brasil. São Paulo: Salesiana, 1980; LIMA, L. A. A face brasileira da catequese: um estudo histórico-pastoral do movimento catequético brasileiro das origens ao documento 'Catequese renovada'. Tese de doutorado. Roma. Universidade Pontifícia Salesiana, 1995.

112 JOÃO PAULO II. Exortação Apostólica Catechesi Tradendae. Sobre a catequese hoje. 1979. 15 ed. São Paulo: Paulinas, 1983.

113 O Sínodo da Catequese de 1979 entregou nas mãos de Paulo VI 34 proposições, fruto das reflexões do Sínodo. Tanto Paulo VI como João Paulo I trabalharam este material, contudo faleceram sem publicar a Exortação sobre a catequese. Foi João Paulo II quem a publica em $16 \mathrm{de}$ outubro de 1979, com o título Catechesi Tradendae. Cf. LIMA, L. A. O Novo Diretório Geral para a catequese e o novo catecismo da Igreja Católica no contexto do movimento catequético, op. cit. In: Revista de Catequese. São Paulo: Unisal, abril/junho, 1998, op. cit., p. 15.
} 
Trata-se de um documento de grande significado para o 'Movimento Catequético' dos últimos anos.

No Brasil, o marco decisivo e referencial para a renovação catequética é o documento Catequese Renovada, aprovada na $21^{\mathrm{a}}$ Assembléia Geral da CNBB, realizada em 15 de abril de $1983^{114}$, o qual valoriza sobremaneira a comunidade eclesial como lócus de iniciação na fé. A Bíblia ganha um lugar central, a catequese assume uma dimensão cristocêntrica; busca-se recuperar a interação fé vida. De grande envergadura foi sua recepção na vida da Igreja. Após a publicação da Catequese Renovada muitas outras publicações e eventos catequéticos foram realizados. As reuniões nacionais já existentes desde os anos 50 se multiplicaram, tornando-se regulares, recebendo o nome de Encontros Nacionais de catequese $(E N C)^{115}$. Destacam-se ainda as Semanas nacionais de catequese. Em 1986 realizou-se a Primeira Semana de Catequese. Após quinze anos, dentro das iniciativas para o novo milênio, realizou-se nos dias 8 a12 de outubro de 2001 a Segunda Semana de Catequese, cujo foco foi a catequese com adultos, tendo como tema 'Com adultos, catequese adulta. Crescer rumo à maturidade em Cristo' ${ }^{116}$. Na Terceira Semana Brasileira de Catequese, 6-11 outubro de 2009, foi lançado o documento da $47^{a}$ Assembléia geral da CNBB de 2009: 'Iniciação à Vida Cristã'. De significado impar, este documento acrescenta o substantivo vida à iniciação cristã, ou seja, a partir de então se fala de iniciação à vida cristã, enfatizando a integração fé-vida e o elemento comunitário da iniciação à fé.

\footnotetext{
${ }^{114}$ CONFERÊNCIA NACIONAL DOS BISPOS DO BRASIL. Catequese renovada: orientações e conteúdo (Documentos da CNBB 26). São Paulo: Paulinas, 1983. Para um estudo detalhado do movimento catequético brasileiro, cf. LIMA, L. A. A face brasileira de catequese: um estudo histórico-pastoral do movimento catequético brasileiro, op. cit.

115 Para uma visão panorâmica dos Encontros Nacionais de Catequese, cf. LIMA, L. A. Com adultos, catequese adulta: uma proposta brasileira. In: Revista de Catequese. São Paulo: Unisal, ano 24, n. 94, abril/junho, 2001.

116 CONFERÊNCIA NACIONAL DOS BISPOS DO BRASIL. Com adultos, catequese adulta (Estudos da CNBB, 80). São Paulo: Paulus, 2001. Prefere-se a expressão catequese com adultos e não catequese de adultos, chamando assim a atenção para o protagonismo do catequizando no processo da iniciação. O Diretório Geral da Catequese, no número 176, ao citar o Directorium Catechisticum Generale ad normam decreti, assim se expressa: "No processo de catequese, o destinatário deve poder manifestar-se sujeito ativo, consciente e corresponsável, e não puro receptor silencioso e passivo". SAGRADA CONGREGAÇÃO PARA O CLERO. Diretório Geral para a Catequese. São Paulo: Paulinas, 1997. Doravante utilizaremos a expressão DGC em referência a este documento.
} 
Em 25 de outubro de 2006 é lançado o Diretório Nacional da Catequese $(\mathrm{DNC}){ }^{117}$, que "é um esforço de adaptação à realidade do Brasil do Diretório Geral de Catequese. Nele, portanto, inspira-se, fazendo, porém as adaptações necessárias, que reflitam a caminhada da Igreja e o movimento catequético brasileiro destes últimos cinquentas anos" (DNC 1). O Diretório Nacional situa a catequese na missão evangelizadora da Igreja conferindo-lhe a tarefa de anunciar o evangelho em terras já evangelizadas, isto é, em lugares carentes de uma nova evangelização. Nesta perspectiva, o Diretório Nacional dá importância ao primeiro anúncio (cf. DNC, n. 30-33), entendido como anúncio querigmático. Hoje mais do que nunca a catequese não pode suprimir esse primeiro momento, tomando-o por pressuposto como na cristandade (cf. n. 91).

Neste rico movimento de aggiornamento da iniciação à vida cristã, significado único tem a redescoberta do catecumenato, entendido com a grande inspiração para toda a catequese, como a pedagogia mais adequada e a que melhor responde aos desafios do mundo pós-cristão. Assim se expressa o DGC sobre a importância do catecumenato para o novo paradigma de transmissão da fé:

O modelo de toda catequese é o catecumenato batismal, que é formação específica, mediante a qual o adulto convertido à fé é levado à confissão da fé batismal, durante a Vigília Pascal. Esta formação catecumenal deve inspirar as outras formas de catequese, nos seus objetivos e no seu dinamismo.

Voltaremos ao catecumenato nos capítulos seguintes, nos quais ele será o assunto primordial, e também no último capítulo, quando estabeleceremos um diálogo entre ele e a instituição paroquial. Através deste rápido retrospecto sobre os principais passos rumo ao novo modelo de iniciação à vida cristã, importa atentar para duas realidades de capital relevância nesse processo de nova proposta de iniciar na fé cristã: 1 - clareza nas terminologias do assunto em voga, com suas devidas aproximações e distinções; 2 - a atenção especial aos adultos, como principais interlocutores da iniciação cristã.

\subsection{1}

\section{Distinção e aproximação dos conceitos}

${ }^{117}$ CONFERÊNCIA NACIONAL DOS BISPOS DO BRASIL. Diretório Nacional de Catequese, op. cit. 
À medida que afirmamos ser a iniciação à vida cristã, isto é, a transmissão da fé às novas gerações um dos principais desafios eclesiais contemporâneos, torna-se necessário situá-la no conjunto da ação evangelizadora da Igreja, bem como oferecer uma melhor aproximação e diferenciação entre alguns conceitos relativos ao processo da maturação da fé. Interessam-nos sobremaneira a diferença e aproximação dos termos catequese e iniciação à vida cristã. A necessidade se justifica pelo resquício do equívoco na história da evangelização que por muito tempo reduziu todo o processo de iniciação à vida cristã à catequese, e esta concebida como mera transmissão de conteúdos, portanto, alheia a um processo mais amplo e integrado de amadurecimento na fé. Em outras palavras, por muito tempo o itinerário de iniciação cristã foi reduzido ao seu segundo momento, ou seja, à catequese propriamente dita, nas funções de ensino-doutrinação, perdendo toda aquela prática mistagógica e processual da qual estava revestida, uma vez que o cultural iniciava na fé, cujo pressuposto hoje cai por terra ${ }^{118}$. Tal atitude, em parte é compreensível pelo fato de naquele contexto se estar imerso num ambiente cultural que por si garantia o primeiro anúncio. Dito com outras palavras, em época de identificação do cultural com o religioso, boa parte da iniciação religiosa estava garantida, urgindo apenas a tarefa do repasse de conteúdos, isto é, a catequização. Contudo, quando o longo processo de iniciação à vida cristã é simploriamente confundido com o momento catequético corre-se o inevitável risco de catequizar sem iniciar na fé, preocupação esta percebida em Aparecida:

Ou educamos na fé, colocando as pessoas realmente em contato com Jesus Cristo e convidando-as para seu seguimento, ou não cumpriremos nossa missão evangelizadora. Impõe a tarefa irrenunciável de oferecer uma modalidade de iniciação cristã, que além de marcar o quê, também dê elementos para o quem, o como e o onde se realiza (DAp. 287).

Posto isto, por iniciação à vida cristã "se entende todo o processo pelo qual alguém é incorporado ao mistério de Cristo Jesus; portanto não se reduz à catequese. Essa é apenas um elemento do complexo processo pelo qual alguém é

118 LIMA, L, A. Novos paradigmas para a catequese no Brasil: apresentando o Diretório Nacional de catequese. In: Revista de Catequese. São Paulo: Unisal, ano 30, n. 117, janeiro/março, 2007, p. 14. 
iniciado na fé cristã" ${ }^{119}$. Trata-se de um intenso processo percorrido para se chegar à realidade da incorporação em Cristo, do ponto de vista experiencial e existencial, realizado e celebrado sacramentalmente.

Para os já batizados, a iniciação à vida cristã consiste em desenvolver os germes da fé já infundidos pelo sacramento do Batismo. Para os não batizados, é o processo que leva ao mergulho no mistério de Cristo ${ }^{120}$. Neste sentido, pode-se então falar de iniciação e reiniciação à vida cristã, neste caso quando, por várias razões, a iniciação não foi completada, realidade esta muito próxima do nosso continente e do nosso país.

A catequese, por sua vez, se situa dentro do vasto e complexo processo de iniciação cristã. É o período mais longo da caminhada, na qual se colocam os fundamentos do edifício da vida cristã (DGC, n. 64-65; 130). O conteúdo catequético conserva sua importância desde que integrado num contexto mais amplo do seguimento a Cristo. No centro da iniciação à vida cristã está uma Pessoa e não uma doutrina. O Diretório Geral da Catequese coloca com clareza a natureza da catequese no conjunto da iniciação cristã: ela é "educação sistemática e progressiva da fé, aliada a um processo contínuo de amadurecimento da própria fé" (DGC, n. 67 e 69).

Importa perceber que a catequese é um serviço específico e fundamental em favor de um itinerário maior de iniciação à vida cristã. Ora, se catequese na sua etimologia significa fazer eco, fazer ressoar, é necessário e supõe-se a existência de um som, uma voz prévia que já tenha sido proclamada. O perigo hoje continua sendo o de dar por pressuposto tal anúncio (eco). Corre-se o risco de uma catequese que não seja precedida por uma ação querigmática. Daí a urgência que ambas as ações sejam realizadas simultaneamente: o anúncio realizado no contexto da catequese e uma catequese igualmente kerigmática ${ }^{121}$.

Outro conceito importante a ser trazido para a reflexão é o da formação permanente, necessário para a continuidade da iniciação cristã. Se teológica e

${ }^{119}$ LIMA, L. A. Catequese a serviço da iniciação cristã: reflexões em torno do tema central da $3^{a}$ Semana Brasileira de Catequese, op. cit. In: Revista de Catequese. São Paulo: Unisal, ano 32, n. 128, outubro/dezembro, 2009, op. cit., p. 15.

${ }^{120}$ Ibid., p. 16.

121 ALCEDI, A, M. Anuncio Misionero’. In: Nuevo Diccionario de Catequética, San Pablo, Madrid, 1999, citado por PASTORINO, M. De una pastoral de mantenimiento, a uma pastoral misionera: apuntes para el encuentro de responsables laicos de montevideo, 27 de setiembro de 2009 , p. 2. 
liturgicamente podemos dizer que alguém está iniciado com a celebração dos sacramentos da iniciação, tal realidade exige permanente aprofundamento. O Documento de Aparecida faz uma clara distinção entre iniciação cristã e catequese permanente: a "iniciação cristã é considerada a 'maneira ordinária e indispensável de introdução na vida cristã e como catequese básica e fundamental'. Garantido a base, 'vira depois a catequese permanente, que continua o processo de amadurecimento da fé" (DAp, 294).

Em meio às aproximações e diferenciações terminológicas onde se situa o catecumenato $^{122}$ ? Qual sua relação com a iniciação cristã? Embora sejam realidades inseparáveis, urge diferenciá-las. O catecumenato foi a instituição iniciática dos adultos à fé nos primeiros séculos do cristianismo a fim de preparar os convertidos ao mistério de Cristo e na vida em comunidade. De caráter catequético-liturgico-moral, constituído por etapas, cujo momento culminante se dava na celebração dos três sacramentos da iniciação, batismo confirmação e eucaristia, presidido pelo bispo na vigília pascal ${ }^{123}$, o catecumenato tornou-se o processo de transmissão de fé mais eficaz da história da Igreja. É na atualidade, a grande redescoberta da Igreja. Com a devida inculturação, trata-se de um modelo privilegiado de iniciação cristã no atual contexto de secularização (cf. CD 14; SC 64-68; AG 14), cujos aspectos metodológicos, pastorais e teológicos serão assunto de todo o terceiro capítulo ${ }^{124}$. Sucintamente pode-se afirmar que iniciação à vida cristã aponta para 'o que', enquanto que o catecumenato nos diz o 'como' da iniciação à vida cristã.

\section{2 .2}

\section{Os adultos como principais interlocutores da iniciação à vida cristã}

Indissociável aos esforços da consolidação do novo paradigma de iniciação à vida cristã está a atenção primordial aos adultos. A intuição mais significativa da mudança pós-conciliar no tocante à iniciação à vida cristã foi a

${ }^{123}$ Cf. BORÓBIO, D. Catecumenato. In: SARTORE, D e TRIACCA, A. M. (orgs). Nuevo Diccionario de Liturgia. Madrid: Paulinas, 1987, p. 298.

${ }^{124}$ As palavras catequese e catecumenato possuem a mesma origem, do grego katecheinm, cujo significado é ressoar um som. A palavra katechesis (catequese) não aparece na Bíblia. Já o verbo katechein aparece no Novo Testamento com dois sentidos: narrar ou relatar sucesso At 21, 21-24; Lc 1,4, e ensinar os mistérios da fé (At 18, 25; Rm 2, 18; Gl 6,6). Cf. CONSELHO EPISCOPAL LATINO AMERICANO. Manual de catequética. São Paulo: Paulus, 2007, p. 62. 
percepção de que se faz urgente voltar-se prioritariamente aos adultos, a partir de uma proposta pastoral também adulta, em vista da construção de uma fé adulta. Em outras palavras, não somente busca-se romper com uma catequese infatilizante, mas mais do que isso cresce a consciência eclesial de que são os jovens e adultos os principais interlocutores da transmissão da fé. É o mundo dos adultos que "deve assumir sempre mais uma importância prioritária" (DGC 258 a). "Trata-se de verdadeiros apelos de quem percebeu que, sem formação de adultos na fé, o cristianismo corre sérios riscos de desagregação, dado o ambiente adverso das sociedades modernas" 125 .

Percebe-se a necessidade de levar a sério as inquietações e necessidades religiosas próprias do adulto, suas angústias existenciais e psicológicos, o ritmo e o processo de sua formação e aprendizagem ${ }^{126}$. Estamos diante de um genuíno salto qualitativo. Nesta guinada pastoral, a catequese com adultos deixa de ser apêndice ou complemento para tornar-se o modelo referencial à qual devem estar subordinadas todas as outras modalidades e atividades catequéticas (cf. CR IV, 120). Significativa são as palavras do Diretório Catequético Geral, ao afirmar que "a catequese de adultos, por ser dirigida a homens capazes de uma adesão plenamente responsável, deve ser considerada a principal forma de catequese" ${ }^{\text {"127. }}$.

Recordemos que a CNBB assume a expressão 'catequese com adultos' na Segunda Semana Brasileira de Catequese no intuito de chamar a atenção para a centralidade do adulto e o protagonismo dos catequizantes.

Ao preferirmos a expressão catequese com adultos em vez de 'para adultos', ou 'de adultos', estamos optando por um tipo de trabalho que necessita do conhecimento das características e potencialidades desses catequizandos. Todos os assim chamados destinatários da catequese devem poder manifestar-se sujeitos ativos, conscientes e co-responsáveis, e não puros receptores silenciosos e passivos, com muito mais razão se são adultos. Por isso, não são considerados simples destinatários, mas interlocutores da nossa proposta de fé. É uma catequese feita de partilha de saberes, experiências e iniciativas, em que ambos os lados criam laços, buscam, ensinam, aprendem e vivenciam a vida cristã ${ }^{128}$.

\footnotetext{
125 PEREIRA, E. N. A formação cristã de adultos: o grande desafio para a Igreja do III milênio. Petrópolis: Vozes, 1994, p. 84.

126 ALBERICH, E. Modelos de catequese com adultos. In: Revista de catequese. São Paulo: Unisal, ano 25, n. 97, janeiro/março, 2002, p. 45.

127 SAGRADA CONGREGAÇÃ̂ PARA O CLERO. Diretório Catequético Geral. São Paulo: Paulinas, 1979, n. 20.

${ }^{128}$ CONFERÊNCIA NACIONAL DOS BISPOS DO BRASIL. Segunda Semana Brasileira de Catequese: Catequese com adultos: histórico, abertura, conteúdos, propostas e compromissos, documentos. São Paulo: Paulus, 2002 (Estudos da CNBB, 84), n. 150.
} 
Vale recordar que a Segunda Conferência Episcopal Latino-Americano (Medellín) já havia assumido o compromisso com uma catequese 'eminentemente evangelizadora', que abrace a 'evangelização dos batizados' ou 'reevangelização dos adultos' e que promova 'novas formas de um catecumenato na catequese de adultos ${ }^{129}$.

Definitivamente, o mundo dos adultos está chamado a ser um dos pontos focais da tarefa pastoral da atualidade ${ }^{130}$. O Documento Catequese renovada no número n. 130 reafirma o que parece ser, portanto, consenso pastoral. É na direção dos adultos que a Evangelização e a Catequese devem orientar seus melhores agentes. São os adultos os que assumem mais diretamente, na sociedade e na Igreja, as instâncias decisórias e mais favorecem ou dificultam a vida comunitária, a justiça e a fraternidade. Urge que os adultos façam uma opção mais decisiva e coerente pelo Senhor e sua causa, ultrapassando a fé individualista, intimista e desencarnada. Os adultos, num processo de aprofundamento e vivencia da fé em comunidade, criarão, sem dúvida, fundamentais condições para a educação da fé de crianças e jovens, na família, na escola, nos Meios de Comunicação Social e na própria comunidade eclesial.

Onde melhor transparece a preocupação pastoral com os adultos é no já referido pedido de restauração do catecumenato. "Que se restabeleça a instituição dos catecúmenos adultos" (LG 64; 66). O próprio título do livro litúrgico do catecumenato expressa a centralidade dos adultos: RICA, Ritual de iniciação cristã de Adultos. Se anteriormente a catequese dos adultos adaptava-se à metodologia infantil, agora, impulsionado pelo retorno catecumenal, prevalece o inverso: a iniciação cristã dos adultos é referência para toda forma de catequese ${ }^{131}$. Eis porque o catecumenato torna-se referência para toda e qualquer modalidade de iniciação cristã. Enfim, catecumenato e adultos estão numa relação de aproximação toda particular.

\footnotetext{
${ }^{129}$ CONFERÊNCIA GERAL DO EPISCOPADO LATINO AMERICANO. A Igreja na atual transformação da América Latina à Luz do Concílio. Conclusões de Medellín. São Paulo: Paulinas, 1968 , n. 8 e 9.

${ }^{130}$ ALBERICK, E.; BINZ, A. Catequese com adultos: elementos de metodologia. São Paulo: Salesiana, 2001, p. 13.

131 Não se pode confundir catecumenato ou catequese de inspiração catecumenal com o movimento neo-catecumenal. Cf. CONFERÊNCIA NATIONAL DOS BISPOS DO BRASIL. Com adultos, Catequese adulta. (Estudos da CNBB 80). São Paulo: Paulus, 2001, n. 108.
} 


\section{3}

\section{Iniciação à vida cristã: participação no mistério de Cristo}

Apresentada a atual consciência e compromisso eclesial-pastoral com a iniciação à vida cristã, e antes de adentrar na metodologia catecumenal, reassumida pela Igreja universal como caminho mais adequado para iniciar alguém no mistério de Jesus Cristo, propomos um aprofundamento teológico sobre o tema da iniciação. De certa forma já entramos no assunto anteriormente quando refletíamos sobre aproximações e distinções de conceitos. Olharemos agora mais de perto o sentido teológico de dizer iniciar/ser iniciado na fé cristã. A reflexão se justifica pela importância em saber 'o que', no 'que' ou 'em quem' a ação eclesial assume o compromisso em iniciar. O grau de clareza no assunto está proporcionalmente associado à qualidade do processo da iniciação.

Se a iniciação é um fenômeno fundamentalmente antropológico e cultural, ela é na sua essência uma realidade religiosa, presente na história de todas as religiões. M. Eliade, renomado historiador das religiões, afirma ser a iniciação "um dos fenômenos espirituais mais significativos da história da humanidade"132. Para o mesmo autor, iniciação é "um conjunto de ritos e doutrinas orais que têm por finalidade a modificação radical da condição religiosa e social do sujeito iniciado"133. É através do conjunto de ritos e símbolos que se entra no âmbito sagrado, na vida religiosa da comunidade ou em um grupo humano com seus valores espirituais ${ }^{134}$.

Qual o específico da iniciação à vida cristã? Não se pode negar que o cristianismo primitivo assimilou muitos elementos da iniciação religiosa comum nas religiões antigas, sobretudo nas chamadas iniciações mistéricas, contudo é bem verdade que a iniciação cristã difere-se em muito das iniciações dos cultos $\operatorname{pagãos}^{135}$.

A diferença por excelência está no 'objeto' da iniciação. Enquanto que as iniciações religiosas antigas são iniciações aos mistérios ${ }^{136}$, a iniciação cristã é

\footnotetext{
${ }^{132}$ ELIADE, M. Iniciaciones místicas. Madrid, 1975, p. 19.

${ }^{133}$ Ibid., p. 10.

${ }^{134}$ Cf. FLORISTÁN, C. Catecumenato: história e pastoral da iniciação, op. cit., p. 15.

${ }^{135}$ CODINA, V; IRARRAZAVAL, D. Sacramentos de iniciação, op. cit., p. 49.

136 'Initia', no plural, equivale aos mistérios próprios dos cultos da área Greco-romana nos séculos anterior e posterior ao nascimento de Cristo'. Cf. FALSINI, R. L'iniziazione Cristiana e $i$ suoi sacramenti, op. cit., p. 8, citado por FLORISTÁN, C. Catecumenato, op. cit. ,p. 15; "Mistério é o
} 
mergulho no Mistério, não em qualquer mistério, mas no mistério de Deus, revelado em Jesus Cristo ${ }^{137}$. O próprio Jesus, ao falar do Reino, utiliza a categoria mistério. "A vós é confiado o mistério do Reino de Deus" (Mc 4, 11; Mt 13, 11; Lc 8,10$)$. Reside aqui sem sombra de dúvida a identidade da fé cristã e a razão de ser da iniciação cristã: adentrar, mergulhar no mistério do Deus de Jesus Cristo. O que se é comunicado na iniciação cristã "não é um corpo de verdades abstratas: ela é comunicação do mistério vivo de Deus" $(C T, 7)$, pois no próprio centro da catequese, encontramos essencialmente uma Pessoa: a de Jesus de Nazaré (CT, 5).

Importa perceber que desde os primórdios do cristianismo a Igreja tem garantido a transmissão da fé às novas gerações e aos novos membros, embora o termo 'iniciação cristã' somente apareceu no século XIX para designar o processo iniciático cristão realizado através dos três sacramentos da iniciação, a saber, batismo, confirmação e eucaristia ${ }^{138}$. Apesar de não se falar no Novo Testamento de um processo de iniciação propriamente dito, ou de um itinerário sistematizado, o que somente acontecerá mais tarde, no segundo século, com a instituição do catecumenato, alguns traços da iniciação podem ser encontras nos escritos neotestamentários: anúncio do querigma, aceitação da fé e conversão, batismo e agregação à comunidade ${ }^{139}$. Desde o início do cristianismo a iniciação foi um processo que inclui entre muitos aspectos a comunicação de Deus que se doa como mistério de amor, o anúncio desse mistério, a aceitação vital de Deus da parte de quem é iniciado, como caminho de conversão, a celebração sacramental e a vivência em comunidade. Algumas passagens dos Atos dos Apóstolos narram a

segredo de certas doutrinas ou de certas práticas cujo conhecimento de adquire pela iniciação". LAMARCHE, D. Le baptême, une iniciation? Paulines-Cerf: Paris, 1984, p. 14, citado por FLORISTÁN, C. Catecumenato, op. cit., p. 16.

${ }^{137}$ TABORDA, F. Nas fontes da vida cristã: uma teologia do batismo-crisma. São Paulo: Loyola. 2. ed., 2009, p. 32.

${ }^{138}$ É importante ressaltar que desde os primeiros séculos do cristianismo a iniciação cristã sempre esteve relacionada aos sacramentos do batismo, confirmação e eucaristia, somente mais tarde denominados sacramentos de iniciação cristã. Ou seja, é no final do século XIX que a expressão iniciação cristão foi utilizada para designar os sacramentos do batismo, confirmação e eucaristia. Foi empregado por liturgistas, em grande parte por influência de Odo Casel, monge beneditino (1886-1948), um dos grandes nomes da reforma litúrgica. O concílio afirma que batismo, confirmação e eucaristia são sacramentos de iniciação cristã. Cf. AG, 14. CONCILÍ́O VATICANO II. Decreto Ad Gentes sobre a Atividade Missionária da Igreja. Documento do Vaticano II, 1965, Petrópolis: Vozes, 1966; PO, 2. CONCÍLIO VATICANO II. Decreto Presbyterorum Ordinis. 4. ed. São Paulo: Paulus, 1965; SC, 71. Cf. FLORISTÁN, S. La iniciación Cristiana. In: Phase. Barcelona: Centro de pastoral Liturgica, 171, 1989, p. 215. Para uma visão detalhada dos sacramentos de iniciação cristã, cf. TABORDA, F. Nas fontes da vida cristã, op. cit. ${ }^{139}$ Cf. FLORISTÁN, C. Catecumenato: história e pastoral da iniciação, op. cit., p. 70. 
estrutura pela qual a Igreja primitiva admitia ao batismo novos membros. Admitese ao batismo quem ouve a mensagem do Evangelho (At. 2, 41; 8,6; 10, 34-44; 15,$7 ; 16,13.32 ; 18,4$ ss.; 19,4), aceita-a na fé (At 8, 12.13.37; 4, 1-4; 5, 14; $16,31.34 ; 18,8)$, estando assim disposto a pautar sua vida pelo caminho de Jesus. Eis porque o batismo é o sacramento da fé, isto é, o sacramento da primeira e fundamental adesão à fé ${ }^{140}$.

Do ponto de vista teológico-litúrgico, a iniciação cristã é um processo litúrgico- sacramental de envolvimento no mistério do Deus de Jesus Cristo, em cujo processo recebe importância central o conjunto de símbolos e ritos, cuja função é ser ponte entre o mistério e o iniciado. São ritos sacramentais, no sentido mais forte da palavra. São elementos visíveis de uma realidade total na qual Cristo, através da Igreja, comunica sua presença e seu mistério na história ${ }^{141}$.

Esvaziada do conhecimento vivencial da vida, morte e ressurreição de Jesus Cristo a iniciação cristã não passa de uma doutrina, de um conjunto de leis e regras a serem aceitos. Iniciação à vida cristã remete fundamentalmente à plena, livre e consciente participação no Mistério de Cristo ${ }^{142}$.

O termo grego mistagogia que etimologicamente significa ser conduzido para dentro do Mistério expressa com mais clareza a dimensão pessoa e social (eclesial) da iniciação cristã: ser iniciado é ser transformado pessoalmente pela

\footnotetext{
${ }^{140}$ Cf. TABORDA, F. Nas fontes da vida cristã, op. cit., p. 40. Muito interessante é a observação de Boróbio, segundo a qual a Igreja primitiva não administrava o batismo de forma aleatória, sem critérios: exigia-se condições fundamentais como a fé a conversão. Em vista de suscitar a fé e amadurecê-la fazia-se uso da pregação, do diálogo, preparação catequética, exigindo a mudança de vida, abandono aos ídolos, aceitação da fraternidade e comunhão de bens. Alguns textos revelam as exigências requeridas At, 2, 37-39; 8, 27-28; 1 Ts 1, 9-10. Somente no segundo século que todos esses elementos serão ordenados institucionalmente, ou seja, na instituição do catecumenato. Dentre muitos desafios que exigiam uma preparação mais autêntica de iniciação cristã, estão: os membros estão imersos num mundo paganizado, sem direito à cidadania, sofrem perseguições, além de não serem muitos numericamente. Cf. BOROBIO, D. Catecumenato, op. cit., pp. 110101.

${ }^{141}$ Cf. BORÓBIO, D. Celebração na Igreja. Vol II. Os sacramentos. São Paulo: Loyola, 1993, p. 25.

${ }^{142}$ Se nos primeiros séculos os padres da Igreja evitavam o termo mistério, no intuito de afastar qualquer confusão com as religiões antigas mistéricas, posteriormente, sobretudo nos séculos IV e V vão admiti-lo e usá-lo para transmitir a riqueza da mensagem cristã. São João Crisóstomo, por exemplo, recorda aos catecúmenos: 'também vós sereis iniciados aos mistérios" (cf. CRISÓSTOMO J. Cat I, 5). Os padres percebem, portanto, o quanto essa terminologia é significativa para expressar sentido da iniciação cristã, utilizando-a de acordo com os fundamentos teológicos cristão Cf. FREDERICI, T. La mistagogia della Chiesa. In: ANCILLI, E. (Ed.). Mistagogia e direzione spirituale. Roma/Milano: Teresianum, 1985, p. 181 (pp. 163-245); MAZZA, E. La mistagogia. Una Teologia della Liturgia in época patrística. Roma: Edizioni liturgiche, 1988, p. 13.
} 
ação do Espírito, é passar de um determinado status de ser a outro, e dimensão coletiva revela a familiaridade, conforme a expressão da Epístola aos Efésios "Já não sois estrangeiros e adventícios, mas concidadãos dos santos e membros da família de Deus" Ef 2, 19). Do ponto de vista social ou comunitário, o termo mistagogia revela ainda outro componente: supõe-se que alguém ou um grupo conduza o neófito ao Mistério ${ }^{143}$.

Nos escritos paulinos, a teologia do mistério torna-se conceito chave para exprimir o conteúdo central da realidade cristã. Em 1 Cor 4, 1 Paulo se apresenta como o dispensador dos mistérios de Deus. Em 1 Cor 2, 7 ele prega insistentemente a sabedoria de Deus. "Ensinamos uma sabedoria divina, misteriosa, escondida, predestinada por Deus antes dos séculos para nossa glória". É na carta aos Colossenses que mistério surge como conceito central para explicar a inteira realidade de Cristo. O objetivo da atividade apostólica é conduzir ao mistério de Deus. "Tudo sofro para que seus corações sejam reconfortados e que, estreitamente unidos pelo amor, sejam enriquecidos da plenitude de inteligência, para conhecerem o mistério de Deus: Cristo, no qual estão escondidos todos os tesouros da sabedoria e da ciência" (1 Col 2, 1-2).

Novamente trazendo à tona as semelhanças e diferenças entre iniciação cristã e as demais iniciações religiosas (religiões mistéricas e primitivas) segundo o estudo de D. LAMARCHE ${ }^{144}$, merece destaque a passagem do não iniciado ao iniciado, através de certos conhecimentos e gestos simbólicos. Em ambos os processos, o batismo é entendido como novo nascimento, passagem das trevas luz, da morte à vida. A insistência entre as semelhanças e diferenças é importante à medida que ressalta a identidade da iniciação cristã.

Boróbio apresenta outras características da iniciação cristã, como constitutivos da participação no mistério de Cristo: uma iniciação totalizante, que abarca todas as esferas e dimensões do ser humano como o racional, o emocional, simbólica, espiritual, corpórea existencial e vital; uma iniciação relacionante que

\footnotetext{
${ }^{143}$ Cf. TABORDA, F. Nas fontes da vida cristã, op. cit., pp. 34-35. Significativo é o sentido que o mesmo autor dá à mistagogia. "A mistagogia é a ação do Espírito que nos introduz no mistério de Deus, pois 'o que está em Deus, ninguém o conhece senão o Espírito de Deus' (1 Cor 2,11). Ela tem caráter vivencial: é iniciação ao seguimento de Jesus. Sua meta, porém, é levar ao Pai, ' para que Deus seja tudo em todos". Ibid., p.11.

${ }^{144}$ LAMARCHE, D. Le baptême, une initiation?, op. cit., citado por FLORISTÁN, C. O catecumenato: história e pastoral da iniciação, op. cit., p. 26.
} 
envolve a relação consigo mesmo, com os demais, com o mundo e com Deus; ela comporta uma dinâmica processual, um antes, um durante e um depois, ou seja é realizada progressivamente, até o futuro escatológico, dada a necessidade de uma sempre re-iniciação, pois nunca se atinge plenamente o mistério no qual se é iniciado $^{145}$. Nesta perspectiva, vale mais uma vez ressaltar o caráter permanente da iniciação cristã. Embora por meio dos sacramentos o candidato esteja iniciado ontologicamente, a busca de conhecimento do Mistério é permanente, o que difere da compreensão da iniciação dos cultos mistéricos. O pagão iniciado, ao final do processo alcançou um estatuto definitivo, ao passo que o batizado deve se esforçar para ser cristão ao longo de sua vida ${ }^{146}$.

Neste sentido, torna-se mais fácil compreender o devido lugar dos sacramentos nesse processo, que são ao mesmo tempo ponto de chegada do cristão e ponto de partida para um aprofundamento sempre maior na fé ${ }^{147}$.

\section{4}

\section{A centralidade da experiência de Deus na iniciação à vida cristã}

O agir pastoral da Igreja não abre mão da experiência como eixo central e objetivo de todo o processo de evangelização. Evangelii Nuntiandi afirma ser a experiência parte essencial na transmissão do Evangelho. "Por acaso existe uma outra forma de expor o Evangelho que não transmitindo aos outros a própria experiência de fé?" (EN 46).

A grande intuição da Igreja primitiva está na íntima relação entre a experiência de Deus e transmissão da fé. Hoje, cresce a consciência de que iniciação à vida cristã não é outra coisa senão um processo que quer conduzir a pessoa à experiência com o Deus de Jesus Cristo e com a comunidade eclesial. Se a iniciação visa auxiliar o fiel, sob a ação do Espírito Santo, a responder ao convite divino, professando explícita e comunitariamente sua fé, a fim de que a revelação divina se lhe torne significativa, passagem obrigatória nesse percurso é a experiência de Deus. O assunto já foi de certa forma mencionado quando

${ }^{145}$ D. BOROBIO, La iniciación Cristiana. Salamanca, Ediciones Sigueme, 1996, pp. 35-39.

${ }^{146}$ Cf. LAMARCHE, D. Le baptême, une initiation?, op. cit., pp. 47-51, citado por FLORISTÁN, O catecumenato: história e pastoral da iniciação, op. cit., p. 26.

${ }^{147}$ LELO, A. F. Iniciação: processo profundamente humano, intinerário de fé, caminho litúrgico, iniciação aos mistérios'. In: Ciberteologia. Revista de Teologia \& Cultura, n. 7, ano II, setembro/outubro 2006, p. 4. 
afirmávamos que a iniciação à vida cristã não pode ser reduzida a valores morais, nem muito menos a um conjunto de normas e preceitos pré-estabelecidos. Por sua relevância, a questão merece um aprofundamento maior.

\subsection{1}

\section{Experiência, termo de difícil compreensão}

Afirmar a centralidade da experiência de Deus na iniciação à vida cristã não significa que os termos estejam clarividentes. Experiência é um dos termos mais difíceis de definição. Ele tem sido utilizado com diversos significados, nem todos aplicados ao campo religioso. Por vezes, é sinônimo de experimento, a ação de experimentar no sentido técnico, através de uma metodologia científica na qual se provoca um fenômeno cuja finalidade é a de submeter uma teoria à verificação ou ao controle. Tem recebido também o sentido de conhecimento acumulado, fruto de um contato prolongado com uma situação. Fala-se de alguém que tem experiência do mundo dos negócios, por exemplo. Por mais que tais concepções são igualmente válidas, seja como ato de experimentar, prática de vida habilidade adquirida, prova ou demonstração, o sentido específico de experiência religiosa que pretendemos refletir vai além dos acima descritos.

A partir de um sentido mais profundo e porta de entrada para a relação com o transcendente, a experiência humana diz respeito a uma percepção, cujo fundamento está no laço de proximidade e intimidade com o outro, e interpretada pelo sujeito que experimenta como significativa para sua vida, sempre num contexto de afeto e de amor ${ }^{148}$ 'Ex periencia é a ciência ou conhecimento que o homem adquire quando sai de si mesmo ( ex) e estuda o mundo por todos os lados (peri) ${ }^{149}$. Resultado do encontro com o mundo, a experiência destrói e reelabora conceitos que se tinha do próprio mundo. Imprescindível nesse processo é a abertura, o despojamento dos preconceitos e idéias para se adquirir uma nova representação da realidade. A preposição ex indica estar orientado para fora,

\footnotetext{
${ }^{148}$ CATÃO, F. Teologia e experiência. In: ANJOS, M. F (Org.). Experiência religiosa: risco ou aventura? São Paulo: Paulinas, 1998, p. 121

149 BOFF, L. Experimentar a Deus hoje. In: Frei BETO et alli. Experimentar Deus hoje. Petrópolis: Vozes, 1974, p. 135.
} 
aberto à, em dialogo com o outro, com o mundo, com Deus. "Daí ser a experiencia não apenas uma ciência, mas uma verdadeira cons-ciencia"150.

Experiência é fundamentalmente uma modalidade e ao mesmo tempo fonte de conhecimento. Contudo, conhecimento aqui, vale ressaltar, recebe uma conotação que vai além de seus sentidos costumeiros, os quais quase sempre entendidos como domínio e controle. Por não ser acessível simplesmente pela atividade discursiva da inteligência, como por exemplo, a conclusão de um silogismo, nem tão pouco pelo saber em razão do acolhimento de uma autoridade ou de tradição histórica, a experiência remete a uma percepção simples e imediata de algo, a qual provoca uma certeza fundada numa evidência específica ${ }^{151}$.

Experiência é uma forma de acesso à realidade, de compreensão e aprendizado relacional, afetivo e efetivo, fruto do contado direto com alguém ou algo. Envolve a inteligência, a afetividade e a vontade, por meio dos quais se adquire um novo conhecimento e uma nova determinação. Está radicada no núcleo mais íntimo do humano, isto é, no nível da liberdade, da consciência e da afetividade. A experiência se converte em aprendizado porque interioriza-se o que viveu e o vivido começa a fazer parte de sua cosmovisão. E outras palavras, internaliza-se o significado da experiência. Trata-se de um aprendizado que nunca se dá por concluído. Cada experiência impulsiona novos aprendizados, uma vez que o objeto último da experiência humana é a realidade e toda a sua complexidade. Todos têm algum tipo de experiência significativa, tais como a do amor recebido, da gratuidade, da beleza e harmonia do mundo, da amizade e solidariedade, da fragilidade, do sofrimento alheio, da busca da plenitude, da transcendência etc.

Jean Mouroux faz a distinção entre três níveis de experiência, a saber, o empírico, o experimental e o existencial. A experiência empírica é a experiência do cotidiano, vivida mas não refletida, por isso parcial, superficial, ingênua. No aspecto religioso, entram nessa categoria os entusiasmos e tantas outras formas de percepções sensíveis do "divino". A experiência experimental é a experiência consciente, provocada, com o auxílio de técnicas e outros elementos que têm a capacidade de manipulação. Haja vista as atuais técnicas de oração, meditação, de

\footnotetext{
${ }^{150}$ Ibid., p. 136.

${ }^{151}$ Cf. MIRANDA, M. F. A experiência do Espírito Santo: Abordagem teológica. In: Perspectiva Teológica. Belo Horizonte, v. 30, fas. 81, maio/agosto, 1998 (pp.161-181).
} 
auto conhecimento e de auto domínio, etc. O terceiro nível da experiência é o existencial, que atinge a totalidade do ser, seus componentes estruturais e seus princípios de ação. É captada e constituída na lucidez de consciência e na generosidade do amor. Os outros níveis de experiência são etapas que precisam ser ultrapassadas em direção a essa experiência totalizante ${ }^{152}$.

Importa perceber que longe de ser um fenômeno efêmero que não deixa nenhum traço, a experiência constitui num alargamento da consciência, de difícil transmissão pelo racionalismo, pois se apoia numa espécie de revelação ${ }^{153}$.

\subsection{2}

\section{Experiência religiosa e experiência de Deus}

A partir da compreensão mais profunda e existencial da experiência humana, acima refletida, passemos agora à experiência religiosa. É comum encontrarmos nos manuais teológicos a distinção entre experiência religiosa, ou experiência do sagrado, de experiência de Deus.

Por experiência religiosa se entende uma forma existencial e pessoal de conhecimento de Deus, desde que o termo conhecimento não esteja condicionado à concepção comum, passível de controle e domínio, necessitada de evidência empírica, por isso mesmo, muito mais próximo à realidade finita. $\mathrm{O}$ conhecimento da fé é fruto da experiência, o que significa dizer, resultante de um contado pessoal, afetivo e de certa forma subjetivo, por isso mesmo, não objetivável. Como ilustração, tomemos o conhecimento do valor da vida humana; o conhecimento de que Deus existe e é benevolente; de que a vida tem um objetivo e um propósito... São objetos de fé e de experiência, por vezes cercado de controvérsias. Em cada uma dessas proposições há oposições e defensores, contudo, determinante é o fato de se estar tratando de fé e experiência, cujas respostas não se conhecem objetivamente ${ }^{154}$. Entram em jogo, portanto, a experiência, o quadro interpretativo, a linguagem. A experiência não pode ser somente objetiva nem tão somente subjetiva. O exclusivismo de uma dessas dimensões gera ou o fundamentalismo, no primeiro caso, ou ao relativismo, no

${ }^{152}$ Cf. MOUROUX, J. L'expérience chrétienne. Paris, 1954, p. 24, citado por MIRANDA, M. F. A Experiência do Espírito Santo, op. cit.

${ }^{153}$ Cf. QUELQUEJEU B.; JOSSUA, J. Experiência. In: Dicionário de conceitos fundamentais de teologia. São Paulo: Paulus, 1993, pp. 298-299.

${ }^{154}$ HAIGHT, R. Dinâmica da teologia. São Paulo: Paulinas, 2004, pp. $42-43$. 
segundo. Interpretação e quadro interpretativo são constitutivos da experiência. Enquanto que os primeiros discípulos fizeram com Jesus uma experiência salvífica, os opositores fizeram uma experiência oposta, considerando-O uma ameaça a ser eliminada. Neste sentido, no quadro interpretativo estão presentes modelos de pensamento, valores, sentimentos, expectativas, teorias ${ }^{155}$.

A experiência do sagrado identifica-se com o que Rudolf Otto descreveu como experiência do numinoso, do mistério tremendo e fascinante, que não necessariamente desemboca em uma experiência religiosa plena. Limita-se, freqüentemente, a uma espécie de ruptura de nível que a prepara, a um pressentimento de outra realidade, de outro mundo no interior do mundo ordinário, sem que se deem os passos para a entrada nele ${ }^{156}$.

É mais do que urgente, sobretudo diante da atual nebulosa espiritual, por vezes marcada por um Deus imanente, ficar atento aos riscos da experiência religiosa, pois toda experiência religiosa acarreta riscos e ambigüidades. Semelhante aos primeiros momentos da existência de uma criança, quando ela ainda não dispõe de um 'eu', isto é, não percebe a distância entre ela e o mundo que a rodeia, a experiência religiosa pode correr o risco de identificação com o sagrado, o que quer dizer a não aceitação da diferença entre o próprio sujeito e o transcendente. A isso se pode chamar de vontade de dissolver-se no divino, eliminando assim o próprio eu, o que significa a não separação e distinção, condição essa essencial para o encontro e o diálogo verdadeiro e autêntico com a alteridade. Nisto consiste a diferença entre o místico e o carismático. O primeiro ama o outro, o segundo ama a experiência do amor. Há ainda o risco da normatividade, do sacrifício por ele mesmo, da culpa, tendência a uma religião de norma e de moralismo, que recusa o gratuito, o gozo ${ }^{157}$.

A experiência religiosa não é especificamente experiência de Deus. O filósofo e teólogo Henrique Vaz classificou a experiência de Deus como experiência de sentido radical da existência. A experiência de Deus é a

\footnotetext{
${ }^{155}$ Cf. MIRANDA, M. F. A experiência do Espírito Santo, op. cit.

${ }_{156}$ QUELQUEJEU B.; JOSSUA, J. Experiência. In: Dicionário de conceitos fundamentais de teologia, op. cit., p. 282.

${ }^{157}$ MORANO, D. Orar depois de Freud. Loyola: São Paulo, 2000, citado por BINGEMER, M. C. L. A Experiência do Deus cristão e sua identidade trinitário, p. 92. In: O mistério e a história: ensaios de teologia em homenagem ao Pe. Félix Pastor, SJ (por ocasião de seus 70 anos). São Paulo: Loyola, 2003, pp. 87-117.
} 
experiência de plenitude ou sentido radical, totalizante, que abarca a totalidade da existência. Ele é experimentado como plenitude que dá sentido, ilumina e liberta $^{158}$. A experiência de Deus jamais pode ser concebida como uma experiência ao lado de tantas outras, como a experiência de ver o sol nascer, uma vez que Deus não é um fenômeno do mundo. Por ser sentido último, então ele perpasse toda a existência. "A experiência de nosso limite, de nosso muro, de nossa fragilidade nos con-vocam para a experiência do ilimitado, da abertura total e do absoluto" 159 .

Segundo Vaz, "a experiência religiosa é uma experiência do Sagrado e a experiência de Deus é uma experiência do Sentido"160. Tal afirmação não significa que a experiência religiosa não seja a experiência de um sentido, e porque não dizer de um dos sentidos fundamentais da existência. Contudo, o Sentido da experiência de Deus não é soma de sentidos parciais ou um sentido entre outros. Não se encerra numa dimensão particular da existência, mas abarca a totalidade das dimensões. "Com efeito, nenhuma presença particular pode, por definição, ocupar o campo total do sentido" ${ }^{161}$.

Enquanto que na experiência de Deus, Deus torna-se um ideal de vida, fonte de compromisso ético e projeto existencial, na experiência religiosa Deus tende a ser buscado em vista de experiências gozosas. Experiência de Deus equivale a dizer consciência da presença do Mistério que dá sentido à aventura do ser humano, consciência esta que possibilita a abertura a experiências mais profundas e inéditas, nas quais se faz descobertas fascinantes de Deus e da própria identidade. Descobre-se cada vez mais ser 'ouvinte da Palavra' e aberto à alteridade. Descobre-se que se é sujeito e que pode transcender-se, que se é dependente, não dono de si. O que significa que experiência autêntica não pode se reduzir a estados da alma, sensações, emoções, ainda que esses elementos possam estar presentes. Fundamental e decisivo são a percepção, consciência, acolhimento, interpretação, sem os quais não se chegaria ao nível da experiência, passando desapercebida a visita de Deus ao sujeito. Toda experiência remete à

\footnotetext{
${ }^{158}$ Cf. VAZ, H. C. L. A experiência de Deus, op. cit., p. 75.

${ }^{159}$ Ibid., p. 157.

${ }^{160}$ VAZ, H. C. L. A experiência de Deus, op. cit., p. 82.

${ }^{161}$ Ibid., p. 85.
} 
realidade profunda da consciência, ou na linguagem bíblica, no coração, que por sua vez urge ser expressa por símbolos, linguagem, isto é, há de ser tematizada.

Próprio da experiência de Deus é a penetração no 'objeto', o que liberta a experiência de pura sensação ou confusão. "A partir desse ponto de vista, a experiência articula-se entre dois pólos bem definidos: o objeto que é fenômeno ou que aparece, e o sujeito que é ciência ou consciência que retorna sobre o objeto para penetrá-lo e igualmente penetrar-se da sua presença"162.

Consciência, adesão, entrega, interpretação são outros termos que expressam a atitude religiosa fundamental, que é 'um convite do espírito a abrir os olhos e deixar-nos surpreender por esse Deus ${ }^{163}$. Decisivo é o fato de Deus ser experimentado como Presença.

A graça é predominante na experiência de Deus. Não se chega a uma autêntica experiência de Deus meramente por esforço humano. Em toda profunda experiência, Deus é experimentado como dado ${ }^{164}$. Para a concretização da experiência de Deus exigem-se certas disposições, chamados 'pressupostos existenciais', sem os quais Deus nunca será uma realidade experimentada: concentração, desprendimento, liberdade interior, oração, silêncio. Uma vivência dispersiva, por exemplo, impossibilita a percepção da Presença. Deus não aparece a um olhar qualquer, ao olhar disperso de quem anda distraído na superficialidade. Nem tão pouco aparece à pessoa dominada pelo interesse, pela ganância, a um olhar dominador e manipulador ${ }^{165}$.

Velasco deu ao sentido radical o nome de 'presença originante', presença essa que atua em todas as dimensões do ser humano, na consciência, no desejo, sentimento, liberdade ${ }^{166}$. No cristianismo, o sentido Radical se fez presença numa existência partilhar, Jesus cristo, o que nos autoriza então a falar de experiência cristã de Deus.

\subsection{3}

\section{Experiência cristã de Deus}

\footnotetext{
162 VAZ, H. C. L. A experiência de Deus, op. cit., p. 77.

${ }^{163}$ VELASCO, M. J. A experiência cristã de Deus, op. cit. p. 7.

${ }^{164}$ Cf. HAIGHT, R. Dinâmica da teologia, op. cit., p. 27.

${ }^{165}$ VELASCO, M. A experiência cristã de Deus, op. cit., p. 30-31.

166 VELASCO, M. El fenômeno místico. Estudio comparado. Madri: Trotta, 1999, p. 255.
} 
Apresentados alguns lampejos da diferença entre experiência do Sagrado e experiência de Deus, daremos agora um passo adiante, de capital importância para o objetivo a que se propõe a iniciação à vida cristã. Dizer experiência de Deus no processo da iniciação à vida cristã ainda não traduz toda a riqueza da dinâmica entre Deus e o iniciante. No intuito de não perder o foco de nossa reflexão, ao debruçar nesta primeira parte da pesquisa sobre a iniciação à vida cristã, importa afirmar que ela, a iniciação à vida cristã, é na sua essência não somente uma experiência de Deus, mas fundamentalmente uma experiência cristã de Deus, isto é, encontro com o Deus revelado em Jesus Cristo. Tendo presente que a experiência de Deus é experiência de Sentido, pode-se então falar de experiência cristã de Deus, isto é, a experiência da presença do sentido radical presente numa existência concreta e historicamente dada, na Pessoa de Jesus Cristo.

O cristianismo anuncia como Boa Nova uma Pessoa, contudo não poucas vezes a mensagem cristã foi com facilidade substituída por uma série de mandamentos, ritos, leis, os quais somente tem sentido a partir de uma relação com essa Pessoa. Muitos confessam uma fé quando, na verdade, não ultrapassam o nível de comportamento com os valores cristãos, o que não significa necessariamente uma relação pessoal com o Deus de Jesus Cristo ${ }^{167}$. Ainda com risco de sermos repetitivos, citemos novamente as palavras de Bento XVI, para quem 'não se começa a ser cristão por uma decisão ética ou uma grande ideia, senão por um encontro com um acontecimento, com uma Pessoa, que dá um novo horizonte para a vida, e com ele uma orientação decisiva “168.

A experiência que os discípulos fizeram com o ressuscitado sempre será fonte de toda experiência cristã de Deus. O encontro deles com Cristo vivo produziu uma experiência nova e única, cuja marca decisiva não está na visão do ressuscitado nem nas testemunhas, mas nessa experiência fundante na qual reconheceram nele o Senhor, sentiram-se amados e chamados a responder a esse amor. Neste encontro foram-lhes respondidas as perguntas e as esperançsa, foramlhes saciados os anseios que nenhuma pessoa humana pode responder e saciar ${ }^{169}$.

${ }^{167}$ Cf. PASTORINO, M. A. De uma pastoral de mantenimiento, a una pastoral misionera, op. cit., p.4.

${ }^{168}$ BENTO XVI. Carta Encíclica Deus Caritas est: do Sumo Pontífice aos bispos, aos presbíteros e aos diáconos, às pessoas consagradas e a todos os fiéis leigos sobre o amor cristão. São Paulo: Loyola, 2006, n. 1.

169 Ibid., p. 101. 
Experiência cristã de Deus, portanto, diz respeito a uma experiência salvífica. Quando a experiência cristã é vivenciada como sentido Radical, torna-se fonte de salvação, tão como fizeram os primeiros discípulos, a tal ponto de professar ‘ Senhor, a quem iríamos? Tu tens palavras de vida eterna'. De acordo com França Miranda

Podemos e devemos mesmo dizer que a tarefa principal da Igreja enquanto sacramento universal da salvação para o mundo (LG 1) é levar homens e mulheres a este encontro salvífico com Jesus Cristo. Todo o resto está em função desta experiência e dela recebe pertinência e sentido ${ }^{170}$.

Embora já esteja implícito na reflexão, torna-se imperioso enfatizar a dimensão trinitária da experiência cristã de Deus. Com ironia afirmou Rahner que se eliminasse o dogma da Trindade no cristianismo, a maioria da literatura religiosa cristã permaneceria inalterável. Conclui o teólogo alemão, os cristãos são na prática 'monoteistas' ${ }^{171}$. Sem o Espírito não nos é possível conhecer o Pai (1 Cor 2, 10-12), nem professar a fé no Filho (1 Cor 12, 31). É pela ação do Espírito que somos iniciados e experimentamos o mistério do Pai e do Filho. Enquanto que durante a vida pública de Jesus os discípulos viveram o dilema da incompreensão, é após a ressurreição que o Espírito lhes abre os olhos e o coração ${ }^{172}$. Todo encontro autêntico com Cristo passa pelo Espírito, da mesma forma que na vida do Filho o Pai e o Espírito atuavam inseparavelmente. Numa perspectiva explicitamente trinitária podemos dizer que o Pai, fonte primeira da vida, a comunica plenamente a seu Filho (Jo 5,26) ressuscitando-O (At 2,24), na força do Espírito $(\mathrm{Rm} 1,4)$. Jesus que, em sua morte, havia restituído o Espírito ao Pai e agora $\mathrm{O}$ recebe em plenitude, pode derramá-1O abundantemente sobre o mundo (At 2,32), o que de fato aconteceu (Jo 20,22) ${ }^{173}$.

Importa perceber a dimensão trinitária de toda experiência cristã de Deus. No centro do cristianismo está um Deus Pessoa, Uno e Trino. Conclui-se que falar Deus ainda não expressa a verdade da relação na iniciação cristã. Para a fé cristã, toda experiência é experiência cristã de Deus, que por sua vez é trinitária, pois "no

\footnotetext{
${ }^{170}$ MIRANDA, F, A experiência do Espírito Santo, op. cit., p. 85.

171 RAHNER, citado por LIBANIO, J. B. Eu creio, nós cremos: tratamento da fé. São Paulo: Loyola, 2004, p. 296.

172 TABORDA, F. Nas fontes da vida cristã, op. cit., p. 114.

${ }^{173}$ MIRANDA, M. F. A experiência do Espírito Santo, op. cit.
} 
principio está a comunhão dos Três, não a solidão do Um"174. Se o Deus cristão é trinitário, isso significa primeiramente que Ele é comunhão entre si, conseguentemente é possível estabelecer com Ele uma relação pessoal, que por sua vez abre-nos à comunhão com os outros. Por sermos a imagem da trindade que é comunhão, carregamos o impulso para a comunhão com os outros e com Deus. Tendo nos criado à sua imagem e semelhança, há decidido colocar-se em comunicação conosco, capacitando- nos com uma estrutura capaz de relacionamento.

\section{5}

\section{Iniciação à vida cristã: dialética entre a graça divina e a resposta humana}

Afirmamos que a iniciação à vida cristã é entendida pela tradição cristã como participação no Mistério do Deus de Jesus Cristo. Mas como se realiza teologicamente esse processo? É iniciativa humana, deve-se ao esforço e boa vontade do evangelizador ou, antes, é oferta divina? Qual a função e a pertinência da mediação eclesial? Como se articulam todos esses elementos na iniciação à fé? No intuito de aprofundar a dinâmica teologal ${ }^{175}$ da iniciação à vida cristã, cabe agora uma reflexão sobre o movimento entre o divino e o humano, isto é, entre revelação gratuita de Deus e a resposta livre do iniciante.

\subsection{1}

\section{A primazia da iniciativa de Deus: revelação como condição para ser iniciado na fé}

A iniciação cristã, narrada nos Novo Testamento, obedece a um itinerário bastante ordenado: pregação da Palavra, ou seja, primeiro anúncio (kerigma, anúncio da vida, morte e ressurreição do Senhor); a fé-conversão suscitados pelo anúncio kerigmático; o batismo em Nome do Senhor, que confere o dom do Espírito, e a incorporação na comunidade ${ }^{176}$. É constante, sobretudo nos Atos dos

\footnotetext{
${ }^{174}$ BOFF, L. A Santíssima trindade é a melhor comunidade. Petrópolis: Vozes, 1988, p. 23.

175 Por dinâmica teologal entendemos a articulação desses elementos no gradual processo de transmissão da fé, tanto no nível mais subjetivo e interno, a saber, dinâmica entre Deus e ser humano, como no âmbito mais objetivo e externalizado, entre os quais se encontram os ritos, a comunidade eclesial, etc.

${ }^{176}$ CODINA, V.; IRARRAZAVEL, D. Sacramentos de iniciação, op. cit., p. 58.
} 
Apóstolos, a afirmação de que para ser batizado é necessário ter antes ouvido a mensagem do Evangelho e aceitá-la na fé. Nota-se que a fé é suscitada pela pregação $(\mathrm{Rm} 10,17)$ e o batismo é a celebração da fé e adesão à mensagem, cujo conteúdo da Boa Nova é o próprio Cristo (At 10,15), escândalo para uns, loucura para outros $(1$ Cor 1,23$)$ mas salvação para os que o aderem ${ }^{177}$.

À primeira vista, tal itinerário parece ser bastante lógico. Contudo, a origem e a possibilidade do itinerário da iniciação são anteriores a esses momentos aparentemente externos. Sem a intenção de fazer dicotomia entre todas as etapas da dinâmica iniciática cristã, há de se reconhecer que a possibilidade da iniciação repousa antes na iniciativa divina, no âmbito da absoluta graça de Deus, ou seja, na categoria teológica chamada revelação. Decerto, Deus faz uso de mediações; indubitavelmente a comunidade eclesial e o evangelizador são fundamentais no processo, da mesma forma que o sim do iniciante é intransferível e decisivo. Porém, a primazia absoluta encontra-se em Deus que toma a iniciativa de se revelar ao humano.

A diferença nevrálgica do sentido do Mistério no Novo Testamento e dos mistérios nas iniciações mistéricas dos gregos aponta para esta direção. Enquanto que para as iniciações pagãs mistério diz respeito a algo secreto, escondido, para o cristianismo o acento está no aspecto revelado, ou seja, Jesus Cristo ${ }^{178}$. A alusão já feita ao sentido etimológico do verbo katecheo, cujo sentido remete a ressoar, fazer ecoar junto aos ouvidos, ajuda a melhor intuir a inquestionável primazia da revelação no discurso teológico da iniciação cristã. O eco, na tradição cristã, é a voz de Deus que ressoa no coração dos homens; é a Palavra que ecoou no mundo a partir do Mistério de Cristo, e continua ecoando através da ação eclesial ${ }^{179}$.

A revelação, ponto de partida para a possibilidade da iniciação cristã, apresenta dificuldades diante do mundo secularizado, cuja marca maior é a autonomia $^{180}$. Percebe-se de fato que a realidade física possui leis próprias, um fundamento autônomo, cuja explicação prescinde dos princípios sagrados. Como

\footnotetext{
177 TABORDA, F. Nas fontes da vida cristã, op. cit. p. 55.

${ }^{178}$ FLORISTÁN, C. Catecumenato: história e pastoral da iniciação, op. cit., p. 16.

179 SILVA, J. A. Relação entre Catequese e Liturgia. Uma visão histórico-teologico geral. In: SIVINSKI, M, e SILVA, A. (orgs). Liturgia no coração da vida. São Paulo: Paulus, 2006, pp. 133-134.

${ }^{180}$ Cf. QUEIRUGA, A. T. Creio em Deus Pai: o Deus de Jesus como afirmação plena do humano. $2^{\circ}$ ed. São Paulo: Paulus, 1993, p 32.
} 
conciliar tal realidade com a revelação? A revelação não seria intromissão de Deus, uma intervenção na realidade? Bem observado por Queiruga, "Deus como rival, a religião como opressão do ser humano, parecem constituir, de uma forma ou de outra, o motor definitivo de todo ataque ao cristianismo ou de todo abandono do mesmo" ${ }^{181}$. O problema parece estar numa compreensão errônea do sentido mais profundo de revelação, como bem nos mostram as reflexões do teólogo catalão acima citado. No afã de afirmar a autonomia, a religião passou a ser vista como uma força heterônoma, vinda de fora, imposta ao ser humano com sua moral, com critérios exteriores e arbitrários ${ }^{182}$, ao passo que o sentido mais original de revelação diz que aquilo que, visto de fora, pode parecer suprema heteronomia (o ser humano submetido ao Absoluto), ... demonstra-se como a suprema e mais impensável forma de autonomia (o ser humano chamado a ser tão ele mesmo que comunga com o fundo do Ser, identificando-se com sua própria norma, numa plenitude que nunca poderia nem sequer sonhar $)^{183}$. Entre a heteronomia e autonomia, surge então a teonomia. "A teonomia deseja, justamente conciliar ambos os pólos: a lei de Deus não é algo alheio ao homem, mas a manifestação de sua própria e mais autêntica profundidade" ${ }^{184}$.

A partir da categoria 'maiêutica histórica', da filosofia grega, Queiruga repensa o conceito de revelação no processo de transmissão da fé. Qual o trabalho da parteira, a tarefa da transmissão da fé não se trata de depositar no discípulo o conhecimento, mas "ajudar a dar à luz o que estava dentro do interloctor"185. Assim, “ajudada pela palavra do mediador, 'nasce' nos ouvidos a consciência da nova realidade que estava ali lutando por fazer-se sentir" ${ }^{\prime 186}$. Trata-se, portanto, de uma descoberta daquilo que já é uma realidade no sujeito, sempre percebido na história, por isso maiêutica histórica, evitando com isso o conceito a-histórico de revelação, similar ao mundo das ideias de Sócrates.

181 Cf. QUEIRUGA, A. T. Recuperar a salvação: por uma interpretação libertadora da experiência cristã. São Paulo: Paulus, 1999 (Col. Teologia hoje), p. 14.

${ }_{182}$ QUEIRUGA, A. T. Recuperar a criação: por uma religião humanizadora. 2. ed. São Paulo: Paulus, 1999 (Col. Teologia hoje), pp. 35-36.

${ }^{183}$ Cf. QUEIRUGA, A. T. Recuperar a salvação, op. cit., p. 53.

${ }^{184}$ QUEIRUGA, A. T. Creio em Deus Pai, op. cit., p. 42. Para aprofundar o argumento o autor reelabora teologicamente alguns conceitos fundamentais, como criação, revelação, eleição, entre outros.

${ }^{185}$ QUEIRUGA, A. T. Recuperar a revelação. A revelação divina na realização humana. São Paulo: Paulinas, 2010, p. 119.

${ }^{186}$ Ibid., p. 119. 
$\mathrm{Na}$ iniciação à vida cristã, a revelação possibilita o iniciante descobrir Aquele que desde sempre está sustentando-o, dando-lhe suporte, "suscitando sua liberdade e empurrando sua história" ${ }^{187}$.

Justamente porque Deus é diferente - como transcendência que não esta ao lado, mas sustenta; como presença que não interfere, mas possibilita toda outra presença - pode se manifestar a nós em toda a realidade e em qualquer realidade ${ }^{188}$.

Deus entra na história para salvar o humano, apoiá-lo para que ele seja ele mesmo $^{189}$, em vista de sua afirmação, para que se realiza com tal. Deus desde sempre está criação ajudando o humano a realizar aquilo que é sua vocação. Portanto, esse apoio, não é imposição ou intervenção, mas "o chamado a ser o que é: a ser livre e pessoalmente o que real e ontologicamente já é pela graça” ${ }^{\text {"190 }}$.

Nunca é demais enfatizar que toda iniciativa vem de Deus. O sujeito só pode reconhecê-Lo porque Deus lhe vem ao encontro ${ }^{191}$. "De uma maneira que ultrapassa os limites de nossa compreensão, (Deus) se revela sempre ao homem, 'pressionando' a consciência humana para que cada pessoa em cada circunstância o possa descobrir. E quando a descoberta se produz, é sempre descoberta do Deus que estava aí, mas que chega e ser revela porque quer"192.

A reflexão de Queiruga é oportuna ao romper com aquela compreensão de revelação, entendida como lista de verdades não acessíveis à razão mas que precisa ser aceita para a salvação ${ }^{193}$, compreensão esta que se tornou barreira para a tarefa da iniciação cristã. Nesta concepção tradicional, revelação se torna "algo passado, sem dinamismo atual e que só é possível repetir ou memorizar" 194.

\section{5 .2}

\section{Fé-conversão: resposta humana à revelação}

A reflexão acima feita mostra-nos que mistério e revelação se equivalem. Para Costa,

\footnotetext{
187 Ibid., p. 179.

${ }^{188}$ Ibid., p. 181.

${ }^{189}$ Cf. QUEIRUGA, A. T. Recuperar a salvação, op. cit., p. 48.

${ }^{190}$ QUEIRUGA, A. T. Recuperar a revelação, op. cit., p. 53.

${ }^{191}$ Ibid., p. 214.

${ }^{192}$ Ibid., p. 218

${ }^{193}$ QUEIRUGA, A. T. Repensar a revelação, op. cit. p. 44.

194 Ibid., p. 100.
} 
Ao falarmos de Iniciação ao Mistério estamos diante do processo conhecido teologicamente como Revelação, com seus principais fatores: a autocomunicação divina e sua iniciativa, a resposta livre e processual do ser humano, a dinâmica da História da Salvação. Participar neste mistério paulatinamente e, a partir dessa experiência, reorientar a vida pessoal e comunitária, é uma experiência do Mistério, uma experiência mistagógica. Mistério que é o próprio Deus se revelando na história da humanidade e como diz Schillebeecks, um 'rosto humanamente reconhecível, a quem proclamamos Messias e Filho de Deus ${ }^{195}$.

Um passo adiante na reflexão teológica e pastoral da iniciação à vida cristã nos mostra que a possibilidade de responder ao convite de adentrar no Mistério é igualmente possibilitada pelo próprio Deus. Deus se antecipa tanto no convite ao humano como capacita-o com uma estrutura capaz de aceitá-lo, sempre no respeito à liberdade. A revelação de Deus se encontra não apenas na proposta mas na capacidade de ser ouvinte da Palavra. Com razão, expressa Libanio: “A fé é esse jogo de liberdades. Deus convida e possibilita a resposta. O ser humano responde embalado pelo própria convite da graça de Deus"196.

Portanto, a acolhida do anúncio do Kerigma, que implica fé-conversão, são momentos constitutivos do itinerário e se devem antes à revelação, o que não significa de modo algum relativizar a participação do iniciante. Pelo contrário, a graça não dispensa a necessidade do empenho humano. Deus convida e atrai para si sem jamais sobrepor-se à liberdade. A revelação é sempre um convite na liberdade, atestam os Evangelhos: Segue-me (Mc 2, 14; 10, 21). Se queres (Mt 19,21). Vinde e vereis (Jo 1, 39). O ato de fé carece de valor se não for assumida como resposta livre a um convite igualmente livre e gratuito. A revelação é sempre um convite à liberdade. Sem dúvida, o ato de fé possui um caráter fundamentalmente livre e pessoal, situa-se na ordem da resposta, evoca consciência e compromisso, experiência, conversão, revisão de vida, novas escolhas ${ }^{197}$.

Reside aqui o paradoxo da liberdade. De um lado, o ser humano é livre para responder positiva ou negativamente a Deus. De outro, essa mesma liberdade está orientada para a divindade, a ponto de negar sua orientação a qual foi criada significaria frustrar-se a sim mesmo. Um risco inclusive para o próprio Deus. Ao

\footnotetext{
${ }^{195}$ COSTA, R. F. A mistagogia e a Iniciação Cristã de Adultos, op. cit., p. 79.

${ }^{196}$ LIBANEO, J. B. Eu creio, nós cremos, op. cit., p. 169.

197 COSTA, R. F. A mistagogia e a iniciação cristã de adultos, op. cit., p. 87.
} 
criar a liberdade, Deus aventurou-se por um caminho diferente. Cria um parceiro diferente de tudo o que até então fora criado, capaz de aceitá-Lo ou negá-Lo. Sofreu e sofre Deus inúmeros nãos da 'liberdade livre' assim como se alegra com inúmeros sins.

O trabalho pastoral da iniciação à vida cristã se presta à tarefa de auxiliar o iniciante a ouvir e a responder ao eco da revelação que habita no seu coração e o atrai para Deus ${ }^{198}$. A partir do sim, leia-se fé, inicia então a aventura do encontro consciente e responsável numa constante busca de conversão. "Tomar consciência do pecado pertence, pois, ao processo de chegar à fé”. Fé e conversão estão intimamente entrelaçados, cuja expressão maior se dá no sacramento do batismo. "O que os sinóticos chamam de conversão equivale a fé em João e em Paulo"199.

Fé-conversão implica mudança radical de atitude, de vontade de desejo, de orientação fundamental. Começa-se a querer e a crer em um novo sentido de vida que o faz mudar de atitude e orientação, a qual conduz a uma mudança do próprio ser, do seu estatuto ontológico. Ela gera uma mudança de existência e de comportamento. Não se muda em um só momento pontual, mas adquire dimensões de duração, de compromisso permanente e existencial.

No Novo Testamento, o termo metanoia equivale à conversão, que por sua vez procede do latim convertere, voltar-se, e que foi traduzido por penitência, o que não expressa o sentido original hoje. Mais do que mero arrependimento dos pecados, conversão é transformação de vida, aquisição de um novo sentido e resposta ao chamado de Deus. Conversão é, portanto, uma exigênciaconsequência fundamental da revelação. Atitude secundária é o afastamento do pecado, ou seja, é conseqüência, da atitude positiva que é adesão a proposta de amor de Deus ${ }^{200}$.

Não se inicia no Mistério por qualquer atitude subjetiva, mas por uma participação ativa e consciente à oferta de Deus. O objeto de fé é dado à fé, a surpreende e impulsiona o sujeito para fora de si, assumindo um compromisso com algo diferente dele próprio ${ }^{201}$.

\footnotetext{
${ }^{198} \mathrm{Cf}$. VELASCO, M. La transmisión de la fa en la sociedad contemporánea, op. cit., p. 86.

${ }^{199}$ FLORISTÁN, C. Catecumenato: história e pastoral da iniciação, op. cit., p. 240.

${ }^{200}$ Ibid., p. 240.

${ }^{201}$ HAIGHT, R. Dinâmica da teologia, op. cit., p. 71.
} 


\title{
3.0
}

\section{O CATECUMENATO ONTEM E HOJE: A REDESCOBERTA DE UM CAMINHO PRIVILEGIADO DE INICIAÇÃO À VIDA CRISTÃ}

Analisadas a identidade, estrutura, desafios e avanços da iniciação à vida cristã, entraremos agora no catecumenato, modo privilegiado e atual de realizar a iniciação. O catecumenato, nascido nos primeiros séculos do cristianismo, foi uma das mais bem sucedidas instituições de iniciação à vida cristã na história da Igreja, e hoje, resgatada pelo Concílio Vaticano II, é a grande aposta para responder, com as devidas adaptações, aos atuais desafios da iniciação à vida cristã.

Uma definição clássica do catecumenato é oferecida pelo liturgista e especialista no assunto, Dionísio Boróbio. Segundo o autor

\begin{abstract}
Se entende por catecumenato (de katejein' - instruir de palavra), em seu sentido mais clássico, a instrução iniciática de caráter catequético-liturgico-moral, criada pela Igreja dos primeiros séculos com o fim de preparar e conduzir os convertidos adultos, através de um processo espaçado e dividido por etapas, ao encontro pleno com o mistério de Cristo e com a vida da comunidade eclesial, expressado em seu momento culminante pelos ritos batismais de iniciação: batismo, ritos pós batismais, eucaristia que, normalmente presididos pelo bispo, se celebram na vigília pascal ${ }^{202}$.
\end{abstract}

O catecumenato nasce, portanto, como preparação à vida cristã aos convertidos adultos, no intuito de que sua fé inicial se transformasse em profissão de fé explícita e sacramentalmente celebrada na comunidade cristã ${ }^{203}$. O catecumenato foi e continua sendo a pedagogia que muito tem a contribuir para a iniciação na fé, haja vista a similaridade entre ambos os momentos culturais: o do nascimento do catecumenato, quando tornar-se cristão era uma opção, e hoje, quando novamente cristãos não se nascem mas se tornam. Afirmar o privilégio desta pedagogia, contudo, carece de uma observação. Dada a íntima relação entre os dois termos, iniciação à vida cristã e catecumenato, pedagogia não quer significar aqui meramente metodologia ou instrumental 'para'. As Diretrizes Gerais da Catequese trabalham de forma impar a relação entre pedagogia de Deus e pedagogia catequética. O documento assim afirma no número 144:

202 BOROBIO, D. La iniciacion Cristiana, op. cit., p. 532.

${ }^{203}$ Cf. FLORISTÁN, C. Catecumenato: história e pastoral da iniciação, op. cit., p. 29. 
É o diálogo que Deus vai tecendo amorosamente com cada pessoa, que se torna sua inspiração e sua norma; dele, a catequese se torna «eco» incansável, buscando continuamente o diálogo com as pessoas, segundo as grandes indicações oferecidas pelo Magistério da Igreja

O catecumenato é uma peça essencial no conjunto de elementos que conduzem à iniciação cristã, de tal forma que sem ele a iniciação não chega à sua plenitude ${ }^{204}$. Portanto, trata-se de um elemento constitutivo da iniciação, o que significa que ao falar de catecumenato se está referindo-se à iniciação e viveversa. Eis a razão primordial porque o termo pedagogia, ao ser associado ao catecumenato e à iniciação recebe um alcance mais profundo do que o costumeiro. Pedagogia catecumenal se aproxima do sentido de mistagogia ${ }^{205}$. Nesta perspectiva, pedagogogia catecumenal, ou metodologia catecumenal diz respeito a uma proposta mistagógica, um caminho que conduz ao mistério (Mistagogia Mystes, mistério, e agein, conduzir ao mistério) ${ }^{206}$.

\section{1}

\section{Origem e desenvolvimento do catecumenato}

Posto isto, torna-se oportuno e necessário conhecer o ontem e o hoje da instituição catecumenal. Para uma melhor compreensão do assunto, e antes de adentrar na restauração do catecumenato proporcionada pelo Vaticano II, para posteriormente dialogarmos com a instituição paroquial, julgamos necessário uma breve visita histórica nos principais momentos do nascimento e desenvolvimento de uma das experiências de iniciação à fé cristã mais bem sucedidas na história da Igreja $^{207}$. Ao voltar às fontes não se quer imitar ou copiar a organização do catecumenato das origens, "mas conseguir a lição histórica que deriva dela como valor perene, e portadora de orientações sempre atuais para a práxis pastoral”208.

${ }^{204}$ Cf. BOROBIO, D. Catecumenato, op. cit. In: SARTORE, D e TRIACCA, A. M. (orgs). Nuevo Diccionario de Liturgia, op. cit., p. 298.

${ }^{205}$ Para uma visão bastante completa do assunto, cf. a tese doutoral de Rosemary Fernandes da Costa. A mistagogia e a iniciação cristã de adultos, op. cit. A autora apresenta com clareza a mistagogia com eixo norteador da pedagogia dos santos padres, sobretudo em Cirilo de Alexandria.

${ }^{206}$ Cf. BOROBIO, D. Catecumenato, op. cit. In: Nuevo Diccionario de Liturgia, op. cit., p. 314.

207 Não é nossa intenção abordar todos os elementos do catecumenato da Igreja primitiva. A bibliografia sobre o assunto é por demais vasta nos mais diversos idiomas. O que pretendemos é refletir alguns aspectos teológico-pastorais relevantes de sua pedagogia, tendo em vista o diálogo que estabeleceremos posteriormente com a estrutura paroquial.

${ }^{208}$ ALBERICH, E.; BINZ, A. Formas e modelos de catequese com adulto, op. cit., p. 39. 
Interessa-nos não somente a história do catecumenal, mas sobretudo os elementos pastorais e teológicos desta proposta pastoral mais do que atual.

\subsection{1}

\section{Do Novo Testamento ao século II}

Os elementos sobre a iniciação cristã são escassos no Novo testamento. Não encontramos nos escritos sagrados um ritual elaborado de preparação para os novos membros que desejassem abraçar a fé cristã. Nem mesmo encontramos lá os termos iniciação ou catecumenato, o que não significa a ausência de uma preparação e critérios de discernimento para quem deseja ser batizado na fé cristã. Várias passagens neo testamentárias apontam para determinadas exigências antes da celebração do batismo, sobretudo em Atos dos Apóstolos, onde melhor se pode perceber os passos necessários para que alguém se tornasse cristão ${ }^{209}$. É clássico o exemplo em At 8,26-39, na qual Felipe anuncia a Boa Nova ao ministro da Rainha da Etiópia e o instrui na fé antes deste ser batizado, que por sua vez pede o batismo e professa sua fé no Cristo. Apesar de não constituir um programa detalhado é constante no Novo Testamento a alusão a alguma preparação imediata aos novos cristãos. Dentre os diversos textos que narram os passos necessários no processo de iniciação, pode-se perceber que o itinerário é composto basicamente pelo anúncio, instrução, profissão de fé, preparação imediata e batismo. Ouve-se a Boa Nova, adere-se a ela, abrindo-se à fé-conversão, cujo sinal sacramental dessa

\footnotetext{
${ }^{209}$ O liturgista e historiador A. Nocent traz a seguinte síntese sobre a atividade apostólica no tocante à iniciação cristã: "Esta época [a apostólica] oferece-nos poucos dados precisos sobre a iniciação: não há descrição de organização que se refira à preparação para os três sacramentos; sabemos, porém, que toda a pregação dos apóstolos tem como fim a fé e o batismo (Mt 28,19-20; Mc 16,15-16; At 2,14-36; 8,12-36; 10,34-43; 16,13-14; 18,15; 19,4-5). O batismo entra evidentemente no ensinamento dos apóstolos que o distinguem do batismo de João (Mt 3,11; Mc 1,8; Lc 3,16; Jo 1,33; At 19,1-5). O batismo de João é rito de conversão (Mt 3,13-17; Mc 1,9-11; Lc 3,21-22; Jô 1,32-34), mas o Cristo, ao recebê-lo, transformou-o, fazendo-o passar de rito de purificação para dom da vida nova (Jo 3,5-6). Quanto aos ritos, o evangelho de Mateus, embora sem dar-nos aquela que será a 'fórmula', diz que o objeto do batismo e da fé é a inserção no Pai, no Filho e no Espírito Santo (Mt 28,19-20); os Atos, ao invés, descrevem-nos melhor o rito batismal (2,38-41). Quanto à confirmação, lendo o NT devemos esquecer a nossa mentalidade contemporânea. Com efeito, temos a impressão de que o Espírito é dado tanto diretamente, como no caso de Cornélio (At 10,44), quanto mediante a imposição das mãos acompanhadas de oração (At 8,5-25; 19,1-6). Sempre nos Atos é mencionado um caso (o dos samaritanos) de imposição das mãos nitidamente diferente do batismo $(8,15)$. A epístola aos Hebreus tem a tendência a manter o batismo distinto da confirmação $(6,1-2)$. Todavia, Paulo nunca fala de imposição das mãos depois do batismo, pondo o dom do Espírito dentro do próprio batismo". NOCENT, A. Iniciação cristã (Evolução histórica da iniciação cristã). In: SARTORE D. \& TRIACCA A. M. (orgs.). Dicionário de Liturgia, op. cit., 595.
} 
atitude fundamental de vida e adesão a Cristo é o batismo, que por sua vez é indissociável à inserção na comunidade (cf. Rm 6,1-11; Ef 1, 13). Outros textos fazem alusão a outros elementos fundamentais do 'processo de iniciação': decisão irreversível (Hb 5,12-6,3); renúncia aos ídolos e servir ao Deus vivo (ITs 1,9-10).

Nesta perspectiva, a origem do catecumenato remete à própria atividade apostólica e à missão mesma de Jesus ${ }^{210}$. No Novo Testamento estão os germes daquilo do que será nos séculos seguintes a instituição de iniciação da Igreja primitiva e sempre referencial para a evangelização. Boróbio recorda que o processo de iniciação à vida cristã das primeiras comunidades herdou da tradição judaica alguns elementos fundamentais. Em outras palavras, o catecumenato bebeu também das fontes judaicas, sobretudo no tocante à insistência à conversão para o seguimento, cuja comunidade apresenta certas condições para fazer parte da comunidade, e em especial a de Qunrán, que exigia, na dinâmica da iniciação progressiva, um tempo de formação e purificação, de provas, e por fim o discernimento. Na mesma perspectiva, para a admissão dos prosélitos, conforme aparece na literatura rabínica do final do século I, exigia-se a pregação missionária em vista da conversão, da purificação dos motivos da conversão, o exame de admissão, realizada por três rabinos, a instrução sobre os mandamentos e a lei de Deus, e por fim a circuncisão e o batismo ${ }^{211}$.

\subsection{2}

\section{Do século II ao IV}

No século II o catecumenato ainda não existe como uma instituição estruturada e oficializada, o que irá acontecer a partir do século seguinte, contudo já é uma prática pastoral bastante difundida ${ }^{212}$. Trata-se muito mais de um 'processo catecumenal como verdade vivida' do que uma instituição ${ }^{213}$. Até alcançar sua estruturação no século III, o catecumenato passa por várias experiências em seu desenvolvimento, amadurecendo-se paulatinamente. Cresce a

${ }^{210}$ Cf. LOPES, J. Catecumenato. In: FIORES, S. G. T. (org). Dicionário de Espiritualidade. São Paulo: Paulus, 1998, p. 100.

${ }^{211}$ Cf. BOROBIO, D. Catecumenato, op. cit. In: SARTORE, D; TRIACCA, A. M. (orgs.) Nuevo Diccionario de Liturgia, op. cit., p. 299.

${ }^{212}$ LOPES, J. Catecumenato, op. cit. In: FIORES, S. G. T. (org). Dicionário de Espiritualidade, op. cit., p. 99.

${ }^{213}$ BOROBIO, D. Catecumenato, op. cit. In: SARTORE, D. e TRIACCA, A. M (orgs). Nuevo Diccionario de Liturgia, op. cit., p. 300. 
preocupação com o discernimento e autenticidade dos candidatos ao batismo, num contexto marcado por perseguições ${ }^{214}$. A grande expansão do cristianismo e o grande número de candidatos exigem que se pense numa formação mais profunda e mais exigente daqueles que professam a fé, num contexto em que as perseguições de um lado, e as seitas heterodoxas de outra, já tinham conduzido cristãos à $\operatorname{apostasia}^{215}$.

A partir do segundo século, a Igreja começa a elaborar um itinerário mais exigentes aos que desejam ser cristãos, o que significa que a instituição catecumenal começa a ganhar corpo. A referência mais antiga que se tem do processo de iniciação dos primórdios da Igreja, além do Novo Testamento, é a Didaqué, ou Doutrina dos doze ${ }^{216}$, na qual encontramos bases mais sólidas da iniciação à fé, sem ainda consistir em uma maior sistematização. $\mathrm{O}$ eixo que norteia a obra é a doutrina dos 'dois caminhos' (morte e vida, luz e sombra, Didaqué 1, 1-6). Salta aos olhos o nexo entre catequese e batismo: "em relação ao batismo, se faça da seguinte forma: depois de haver ensinado tudo que o precede, batizes-se em nome do Pai, do filho e do Espírito Santo" (Didaqué 7, 1). Já nessa obra, relativamente recente, verifica-se o envolvimento da comunidade no processo de transmissão da fé (Didaque, 9). Todos os fiéis, com o jejum e a oração participavam da iniciação do catecúmeno. O mesmo pode ser percebido nos escritos de Justino, onde toda a comunidade reza e jejua com os catecúmenos, numa atitude de participação (I Apol. 61, 2) ${ }^{217}$.

Neste contexto, contribuição fundamental oferecem os escritores apologéticos ${ }^{218}$. Os padres apologistas não se cansam em defender a originalidade

\footnotetext{
${ }^{214}$ Cf. FLORISTÁN, C. Catecumenato: história e pastoral da iniciação, op. cit., p. 83.

${ }^{215}$ C. CABIÉ, H. V. A iniciação cristã. In: MARTIMORT, A. G. A Igreja em oração. Introdução à liturgia. Petrópolis: Vozes, 1991 (Volume 3 - Os sacramentos), p. 35.

${ }^{216}$ Trata-se de um livreto de 16 capítulos, provavelmente escrito na Palestina ou Antioquia da Síria, por volta dos anos 110. É o mais antigo manual da religião cristã ou catecismo de que dispomos. Cf. ZILLES, U. (trad). Didaqué: catecismo dos primeiros cristãos. In: Col. Fontes da catequese, 1. Petrópolis: Vozes, 1988. Nesse precioso documento é possível conhecer as origens do cristianismo, a organização e vida das primeiras comunidades cristãs. Portanto, através desse texto sabe-se que no final do século I já havia uma preparação ao batismo dos novos membros do cristianismo, embora ainda não fosse utilizado o termo catecumenato. Cf. FLORISTÁN, C. Catecumenato: história e pastoral da iniciação, op. cit. p. 76.

${ }^{217}$ NEUNHEUSER, B. O Catecumenato. In: BARAÚNA, G. (org.) A sagrada liturgia renovada pelo Concílio. Petrópolis: Vozes, 1964, p. 519.

${ }^{218}$ Padres apologistas foram os padres do segundo século da era cristã que escreveram apologias nas quais procuravam justificar e defender a fé cristã perante os pagãos. Entre os apologistas estão Justino, Teófilo de Antioquia, Tarsiano. "A palavra "apologistas" designa aqueles escritores
} 
da iniciação cristã em relação ao paganismo. Justino ${ }^{219}$, filósofo e teólogo leigo e mártir do século II, escreve entre 163 e 167 um compêndio de doutrina cristã na qual aborda o processo de conversão à fé daquele tempo. Ele expõe em uma apologia a Antônio Paio, no capítulo 65, 1, o modo como o catecúmeno deve ser instruído na fé. Destacam-se dois elementos principais: ensino (doutrina) e liturgia (oração- jejum), o que comprova a íntima relação entre doutrina e liturgia ${ }^{220}$.

Orígenes figura entre os grandes contribuintes pela institucionalização do catecumenato $^{221}$. Contemporaneamente, Tertuliano ${ }^{222}$, na comunidade cristã de Cartago, África, coopera igualmente com a história do catecumenato, sobretudo em duas obras: De Baptismo e De oratione ${ }^{223}$. Ele enfatiza a necessidade do conhecimento das verdades de fé concomitante à preparação ascético-moral. Faz parte ainda uma prova adequada para poder ser aceito. Na dúvida, preferia-se prorrogar o catecumenato ${ }^{224}$.

Há de ressaltar a sensibilidade dos padres ao inculturar a mensagem cristã na realidade dos interlocutores, sobretudo na cultura helênica. "Tertuliano, por exemplo, para descrever a renúncia batismal usa a palavra eieratio, termo jurídico

cristãos antigos que se propunham defender a nova religião das pesadas acusações dos pagãos e dos judeus, e difundir a doutrina cristã em termos adequados à cultura do próprio tempo. Assim nos apologistas está presente uma dupla solicitude: a mais propriamente apologética, de defender o cristianismo nascente (apologhía em grego significa precisamente "defesa") e a "missionária", que expõe os conteúdos da fé numa linguagem e com categorias de pensamento compreensíveis aos contemporâneos". BENTO XV. São Justino. Filósofo e mártir. Audiência Geral. Quarta-feira, 21 de março de 2007. Disponível em: http://www.vatican.va/holy_father/benedict_xvi/audiences/2007/documents/hf_benxvi_aud_20070 321_po.html.

${ }^{219}$ Justino, filósofo pagão, convertido em Éfeso, nasceu em Siquém, Palestina. Em Éfeso, entra em contato com o platonismo e daí passa para o estudo do cristianismo. Vai a Roma onde funda uma escola. Cf. FIGUEIREDO, F. A. Curso de Teologia Patrística I: a vida da Igreja primitiva (séculos I e II). Petrópolis: 1983.

220 NEUNHEUSER, B. O catecumenato, op. cit. In: BARAÚNA, G (org). A Sagrada Liturgia renovada pelo Concílio, op. cit., p. 519.

221 Ele "concebe o catecumenato como ingresso na fé através da catequese que expresse breve compêndio da fé: o mistério cristão aí é exposto nos seus elementos essenciais; conservamos muitas homilias em que Orígenes exorta os catecúmenos à penitência NOCENT, A. Iniciação cristã (Evolução histórica da iniciação cristã), op. cit. In: SARTORE, D. e TRIACCA, A. M. (orgs). Dicionário de Liturgia, op. cit., p. 595.

${ }^{222}$ Tertuliano nasceu por volta de 160, em Catargo. Escreveu importantes obras que ajudam a conhecer a sociedade, a cultura, a Igreja da época. Cf. ROBNER, H. R. Manual de Patrologia. Petrópolis: Vozes, 2003, pp. 160-171.

223 É Tertuliano quem utiliza pela primeira vez a palavra catechumenus, para designar o candidato ao batismo. Cf. BERNARDINO, A. (org). Dicionário de Patrística e Antiguidades Cristãs. Petrópolis: Vozes, 2002, p. 273. Clemente Alexandrino por sua vez emprega com frequiência o substantivo catecumenato. Cf. Ibid., p. 271.

${ }^{224} \mathrm{Cf}$. NEUNHEUSER B. Catecumenato, op. cit. In: BARAÚNA, G. A sagrada liturgia renovada pelo Concílio, op. cit., p. 519. Tertuliano exorta os catecúmenos a se prepararem para o batismo "com orações assíduas, jejuns, prostrações e vigílias" (De baptismo, 20,1). 
(extra cultual, portanto) que significa 'desligamento de um contrato de serviço ou associação" 225 .

São nos séculos III e IV que o catecumenato ganhará uma estruturação em todas as comunidades cristãs. "O verdadeiro catecumenato é o da Igreja missionária do século III, quando a iniciação sacramental exige ainda uma séria formação prévia e na qual o acesso à catequese oficial é privilégio exclusivo dos crentes" 226 .

\section{3}

\section{Tradição apostólica de Hipólito de Roma}

Do início do século III, com a Tradição apostólica de Hipólito de Roma $^{227}$, data as primeiras diretrizes ou normas instituídas da Igreja no tocante ao itinerário catecumenal. Trata-se de uma das principais referências sobre o catecumenato primitivo, e que de certa forma dão a base para a estruturação da instituição catecumenal. Ela oferece uma visão completa do que foi a pedagogia catecumenal da Igreja primitiva na primeira metade do século III. Dada sua importância enquanto referência para a história do catecumenato é oportuno apresentar sucintamente os principais passos do itinerário proposto por Hipólito.

A obra de Hipólito de Roma apresenta o itinerário catecumenal em três etapas: admissão-entrada ao catecumenato (TA 15-16); tempo de catecumenato (TA 17-19) e eleição para o batismo (TA 20). Após a evangelização prévia, isto é, o primeiro anúncio, presumida a conversão primeira, o candidato é apresentado pelo padrinho à comunidade para ser admitido ao catecumenato, passando por um severo exame de moralidade de vida: estado de vida, suas reais motivações e

225 Cf. SILVA, J. A. A iniciação cristã em sua evolução histórica: alguns apontamentos para estudo, op. cit. Outras expressões como sacramenti testatio ou signaculum fidei que significam o juramento de fidelidade que o soldado faz ao imperador romano são usadas para exprimir a profissão batismal. Tertuliano, ao falar da unção pos-batismal, afirma que ela deve ser abundante, que deve escorrer por todo o corpo, alusão ao antigo Testamento, unção de Aarão por Moisés, além do que os gregos e romanos ungiam-se com o óleo por diversos motivos, sobretudo com fins terapêuticos e esportivos. CHUPUNGO, A. Adaptação. In: SARTORE, D. e TRIACCA, A. M. Dicionário de Liturgia, op. cit., pp. 3-4, citado por SILVA, J. A evolução cristã em sua evolução histórica: alguns apontamentos para estudo, op. cit.

${ }^{226}$ DUJARIER, M. Le parrainage des adultes aux trois premiers siécles de l'Eglise. Recherche historique sur l'évolution et des étapes catéchuménales avant 313. Cerf: Paris, 1962, citado por FLORISTÁN, C. Catecumenato: história e pastoral da iniciação, op. cit., p. 75.

${ }^{227}$ Cf. NOVAK, M. G. (trad.); GIBIN, M. (intr.) Tradição Apostólica de Hipólito de Roma. Liturgia e Catequese em Roma no século III. 2 ed. Petrópolis: Vozes, 1981. A obra foi escrito em Roma pelo ano 215 ou 225. 
sinceridade de conversão. É verificado igualmente seu estado familiar, social e, sobretudo profissional, pois certas profissões eram contrárias à condição de discípulo de Cristo. Tanto Hipólito como Tertuliano falam de um rito de admissão perante os 'doutores'. Significado fundamental nesse processo tem o sinal da cruz na fronte do candidato, como expressão de fé em Cristo. Os padrinhos testemunham a sinceridade de seus afilhados ${ }^{228}$. Só então o candidato é admitido ao grupo dos catecúmenos, sendo, portanto, denominado como tal (Katechumenoi ou ouvintes). Inicia-se um longo período de formação, catequese-ensino, cuja duração é de aproximadamente três anos. Aumentam as exigências de conversão e transformação de vida ${ }^{229}$. O que se pode perceber é a íntima relação entre liturgia e catequese, ou seja, perfeita integração entre formação-catequese, moralconversão, e ritual. A ênfase na conversão e maturidade cristã é acompanhada da abordagem doutrinal e bíblica em chave histórico salvífica, bem como pela introdução à oração e aos símbolos da fé. Vale ressaltar a importância dos ritos durante o itinerário formativo. Oração, imposição das mãos, sinal de exorcismo, que podia ser feito pelo catequista, clérigo ou leigo. Neste período os catecúmenos não participavam das assembléias dominicais com os demais fiéis, mas apenas da primeira parte da missa (após a última leitura da Palavra de Deus), pois ainda não estavam associados à oração dos batizados.

Ao serem eleitos ao batismo, e quando próximos a receberem os sacramentos da iniciação, dava-se início a uma preparação mais intensa e sistemática das verdades reveladas, cujo início era no começo da quaresma. No oriente, recebiam o nome de iluminados - photizómenoi. No Ocidente eram chamados competentes; em Roma, electi, eleitos. Era um momento intenso de oração e penitência não apenas do eleito, mas de toda a comunidade dos crentes. Prosseguia-se com a inscrição do nome. Os eleitos são convocados para catequese própria onde lhe são apresentados os artigos da fé, ou seja, o credo (traditio symboli, o símbolo da fé), sinal de adesão pessoal à fé transmitida pela Igreja. Juntamente com o Credo recebia-se o símbolo do Pai Nosso. Uma série de

\footnotetext{
${ }^{228}$ Cf. FLORISTÁN, C. O Catecumenato: história e pastoral da iniciação, op. cit., p. 83-84. ${ }^{229}$ Cf. Ibid., p. 84; CABIÉ, R. A iniciação cristã, op. cit. In: MARTIMORT, A. G. A Igreja em oração - Introdução á liturgia - volume 3, op. cit., p. 37.
} 
$\operatorname{exorcismos}^{230}$, chamados escrutínios, acompanhava esse processo, cujo significado aponta para a força transformadora de Deus na luta contra o mal.

O ponto culminante do processo da iniciação catecumenal se realizava na noite da Vigília pascal, com a celebração dos sacramentos do Batismo, Confirmação e Eucaristia. Os passos mais próximos à celebração sacramental, isto é, durante a semana santa, eram marcados por vários momentos (TA parte II): banho, na quinta-feira santa; na sexta-feira santa início do jejum, no sábado santo o bispo impõe as mãos sobre os eleitos, exorciza-os, sopra-lhes na fronte, nos ouvidos e nas narinas (TA II). Durante a vigília que ocorria durante toda a noite do sábado, realizava-se o rito sacramental, igualmente marcado com os ritos correspondentes. Os batizandos se despojam de suas vestes e o bispo consagra-os com os óleos. Renunciam a satanás e em seguida são ungidos com o óleo do exorcismo. Seguia-se então o batismo com três imersões. Logo após, o neófito era novamente ungido, agora com o óleo de ação de graças. Vestiam-se com vestes brancas e se apresentam à comunidade reunida, onde o bispo faz-lhes o sinal da cruz na fronte e lhes dá o beijo da paz. Eles, agora batizados, rezam com o povo e participam da Eucaristia ${ }^{231}$.

A última etapa do longo e completo processo de iniciação correspondia à mistagogia, aprofundamento da experiência dos mistérios sacramentais recebidos. Durante a semana da páscoa os neófitos iam diariamente à Igreja para, através das catequeses mistagógicas, aprofundarem o sentido dos sacramentos recebidos ${ }^{232}$. Importante ter presente a concepção dos santos padres, para quem os mistérios não se explicam antes de serem experimentados. Primeiro vem a experiência e

\footnotetext{
230 “Os exorcismos, no caso, são ações litúrgicas, através das quais (no fundo) se celebra a ação de Deus sobre os catecúmenos em seu processo de conversão e crescimento na fé. Confia-se no poder libertador de Deus, pedindo-lhe a intervenção para que, na caminhada preparatória para o sacramento da regeneração, expulse do catecúmeno todos os males, vícios, apego aos ídolos, defeitos de caráter, personificados pela figura de Satanás como raiz desses males. E que o espaço dela seja ocupado pelo Espírito de Cristo, o Espírito Santo. Daí, inclusive, também há um momento em que se intima o demônio a sair: "Portanto, demônio maldito, sai dessa pessoa...". No fundo, é a proclamação da soberania de Deus sobre todo Mal existente, acolhida pouco a pouco pelo catecúmeno, à medida que vai conhecendo Jesus Cristo (Nota minha. Para mais detalhes, cf. BÉRAUDY, R. Os escrutínios e os exorcismos. In: Concilium. Revista International de Teologia. Petrópolis, v. III, fasc. 22, 1967, p. 60-64”. SILVA, J. A. A evolução cristã em sua evolução histórica, op. cit.

${ }^{231}$ Cf. NOVAK, M. G. ( trad.); GIBIN, M. (intr.) Tradição Apostólica de Hipólito de Roma, op. cit., 'os que receberão o batismo', parte II, p. 60.

${ }^{232}$ FLORISTÁN, C. Catecumenato: história e pastoral da iniciação, op. cit., p. 87.
} 
somente depois a explicação ${ }^{233}$. Portanto, trata-se de um tempo forte onde se experimenta, saboreia-se e entende-se os mistérios sacramentais recebidos, uma vez que "a explicação prévia iria tirar do batizando a receptividade para o evento e, conseqüentemente, a experiência do mistério" ${ }^{234}$.

Nos séculos III e IV estão, portanto, o apogeu do catecumenato. Os escritos dos santos padres são testemunhas da riqueza do catecumenato nesta época, como por exemplo, as grandes obras da catequese batismal e pós-batismal de São Cirilo de Jerusalém (+ 386), Santo Ambrósio de Milão (+ 397), Teodoro de Mopsuéstia (+ 428); São João Crisóstomo (+ 407); Santo Agostinho (+ 430), entre outros. De fundamental importância nesta dinâmica catecumenal são as catequeses mistagógicas do século IV e V, tanto pré-batismal, destinadas aos candidatos ao batismo, como pósbatismal ou mistagógicas, dirigidas aos neófitos, realizadas na semana após a celebração sacramental ${ }^{235}$.

Eis, sucintamente o processo catecumenal, que "não se dava como um simples ensinamento em forma de aula, mas que se fazia conjuntamente com os ritos litúrgicos”236. Em linhas gerais apresentamos o que foi a iniciação cristã catecumenal da Igreja primitiva. Importante deixar claro que apesar de algumas diferenças ente algumas comunidades, as características básicas estão presentes em todos os modelos de iniciação daquele período, sobretudo as etapas constitutivas do processo: a etapa missionária em vista do suscitar da fé e da conversão, culminando com a entrada no catecumenato; a etapa catecumenal, três ou mais anos, período mais intenso de formação - instrução. Ao término desse período, a realização de um novo exame sobre o comportamento do catecúmeno; etapa quaresmal, com algumas semanas, preparação intensa em preparação ao batismo e eucaristia na noite pascal; e a etapa do tempo pascal ou tempo de mistagogia, para aprofundar a graça sacramental recebida.

\footnotetext{
233 MARTINS, J. L. No espírito e na verdade - Introdução teológica à liturgia. Volume 1. Petrópolis: Vozes, 1996, p. 285.

${ }^{234}$ NOCKE, Franz-Josef. Doutrina específica dos sacramentos. In: SCHNEIDER, T. Manual de dogmática. Vol. 2, 2 ed. Petrópolis: Vozes, 2002, p. 219.

235 Dentre as catequeses mistagógicas, se destacam as de Cirilo de Jerusalém. Ele escreveu 24 catequeses para o tempo pascal e quaresmal. Ainda desenvolveu 5 catequeses mistagógicas para explicar o batismo, confirmação e eucaristia. Para uma visão completa da visão teológico-pastoral delas, cf. COSTA, R. F. A mistagogia e a iniciação cristã de adultos, op. cit.

${ }^{236}$ CHUPUNGCO, A. Inculturación litúrgica, op. cit., p. 166.
} 


\subsection{4}

\section{A decadência do catecumenato: da adesão pessoal à fé ao catecumenato social}

Se foram o segundo e terceiro séculos o período auge do catecumenato, após a paz constantina ${ }^{237}$ ele entra num processo de paulatina decadência. Ele nasce no segundo século, desenvolve-se e se estrutura no terceiro e meados do IV, transforma-se na segunda metade do século IV, entra em decadência, até desaparecer nos séculos VI e VII ${ }^{238}$.

As motivações para abraçar a fé cristã já não eram as mesmas. Depara-se com as ambigüidades das reais motivações do catecúmeno, entre as quais estão os interesses políticos e sociais, a tendência de estender ao máximo a permanência no catecumenato para gozar ao máximo da vida mundana, retardando assim o batismo-conversão para o fim da vida ${ }^{239}$. A conversão já não é mais a grande exigência para entrar nas fileiras do cristianismo. Desaparece progressivamente o itinerário gradual, experiencial e comunitário da iniciação à fé. Motivados pelos interesses fornecidos pelo casamento igreja-estado, uma multidão aspira ao batismo ${ }^{240}$. "Uma ingente multidão de pessoas solicita sua entrada na comunidade cristã. Mas os motivos dessa decisão com frequiência são interesseiros e alheios a um desejo de conversão à fé cristã"241.

Em pouco tempo a Igreja perdeu uma organização vital de preparação de novos fiéis capazes de dar razões da própria esperança. Ao adaptá-lo à nova

237 Em 313, o edito de Milão concede liberdade religiosa aos cristãos. Em 380, o edito de Tessalônica impõe a todos os súditos do Império o símbolo de fé niceno. Em 391 acontece a proibição do culto pagão e declaração do cristianismo como "religião do Estado".

238 "A história do catecumenato se desenvolveu em três etapas. No século III, as exigências de uma Igreja missionária levavam a sério a preparação para o batismo: exame de entrada, longo período de formação e novo exame antes da admissão ao batismo. Durante os séculos IV e V mudam as circunstâncias devido à conversão dos imperadores, quando se constituiu a cristandade. A ênfase passou para o período quaresmal, em detrimento do longo e rico processo catecumenal. Finalmente, o século VI só conservará ritos mais ou menos condensados e o batismo de crianças substituirá o catecumenato". DUJARIER, M. Le parrainage des adultes aux trois premiers siécles de l'Eglise, op. cit., p. 65, citado por FLORISTAN, C. O Catecumenato: história e pastoral da iniciação, op. cit., p 75 .

${ }^{239}$ Cf. BORÓBIO, Catecumenato, op. cit. In: SARTORE, D. \& TRIACCA, A. M. (orgs). Nuevo Diccionario de Liturgia, op. cit., p. 301.

${ }^{240}$ Para conseguir algum cargo público, tinha-se que ser pelo menos catecúmeno, além do que "ser ou não ser cristão condicionava a tranqüilidade e a boa reputação dos indivíduos na sociedade". BASURKO X. O culto cristão na Igreja o Império (313-590). In: BOROBIO, D. (Org.). A celebração na Igreja 1: Liturgia e sacramentologia fundamental, op. cit., p. 73.

${ }^{241}$ BASURKO, X. A vida litírgico-sacramental da Igreja em sua evolução histórica. In: BOROBIO, D. (org.) A celebração na Igreja-vol. 1, op. cit., p. 73. 
realidade cultural, o acento da iniciação passa a ser colocado na preparação próxima aos sacramentos, ou seja, quem pedia o batismo recebia uma iniciação abreviada em vista do batizado, em detrimento do processo catecumenal ${ }^{242}$. A caminhada catecumenal de três anos está agora reduzida ao tempo da quaresma, conseqüentemente diminui a importância dos ministérios laicais, recebendo maior relevância o ministério dos presbíteros e bispos, os quais assumem a responsabilidade da catequese intensiva na quaresma ${ }^{243}$.

Nesse contexto, tem início o batismo de crianças, tornando-se uma prática generalizada a partir do século VI. A iniciação cristã já não é mais um processo que envolve toda a comunidade, nem muito menos percorrida de acordo com o ano litúrgico. Ela adentra pelos caminhos da prática individual e familiar. Diante da fragilidade dos recém-nascidos, da mortalidade infantil, entra em voga a mentalidade segundo a qual se deve batizar o quanto antes, quam primum, em qualquer dia do ano $^{244}$. Portanto, com a chegada da cristandade desaparece o complexo processo catecumenal, agora reduzido à etapa de ensino-instrução, via de regra dirigido a crianças. Trata-se do assim chamado catecumenato social, onde a comunidade cristã e a própria sociedade (ou civilização cristã) exerciam o papel da transmissão da fé, restando à Igreja tão somente a preocupação com a instrução doutrinal, isto é, a catequese. É esta a herança que recebemos da cristandade $^{245}$.

O liturgista Xavier Basurko resume as evoluções, ou retrocessos posteriores:

\footnotetext{
${ }^{242}$ Nesse processo de reestruturação do catecumenato, a igreja começa a distinguir "claramente, em meio a essa massa ingente de catecúmenos apenas nominais, os verdadeiros aspirantes ao sacramento da conversão cristã. A partir de então os pastores vão concentrar a atenção e o cuidado na preparação moral, doutrinal e ritual desses últimos [os aspirantes de verdade], que é efetuada no espaço de quarenta dias de preparação para a páscoa; a partir do século IV, a instituição quaresmal contém uma marcada ênfase batismal. O rito de passagem essencial para essa nova categoria no interior do catecumenato (tempo dos "eleitos", dos "competentes") é a inscrição do nome, que tende a coincidir com o próprio início da quaresma". BASURKO, X. O culto cristão na Igreja o Império (313-590), op. cit. In: BOROBIO, D. (Org.). A celebração na Igreja 1, op. cit., p. 74.

${ }^{243}$ Cf. BORÓBIO, Catecumenato, op. cit. In: SARTORE, D. e TRIACCA, A. M. (orgs.) Nuevo Diccionario de Liturgia, op. cit., pp. 302-303.

${ }^{244}$ Cf. BASURKO, X. A vida litírgico-sacramental da Igreja em sua evolução histórica. In: BOROBIO, D. (org.) A celebração na Igreja - vol. 1, op. cit., p. 92.

${ }^{245}$ Cf. LIMA, L. A. 13 Encontro Nacional de Presbíteros. 03 a 09 de fevereiro de 2010, Itaici, Indaiatuba - SP. Iniciação à vida cristã: Tema prioritário da $47^{\mathrm{a}}$ Assembleia Geral da CNBB (abril 2009) e da III Semana Brasileira de Catequese (outubro 2010 - Prot. 15/2010 - 13 ENPPe.
} 
A partir do século VI, generaliza-se o batismo de crianças. A pastoral da Igreja e o direito civil (com suas penalidades e sanções) se unem para consolidar essa prática e dotá-la de um caráter de obrigação cada vez mais estrita. Logicamente, desaparecem pouco a pouco, com essa mudança, os catecúmenos adultos, e a instituição catecumenal se converte em um amálgama de ritos fossilizados que constituíram, durante séculos, uma parte do rito batismal na liturgia romana. A iniciação cristã, que em épocas anteriores fora objeto de celebração solene e comprometida de toda a comunidade, em datas relevantes do ano litúrgico (em Roma, sobretudo, na Páscoa e em Pentecostes), passará paulatinamente a ser um assunto individual ou familiar. A fragilidade dos recém-nascidos, a mortalidade infantil, leva a equipará-los aos enfermos e a conceder-lhes o sacramento em qualquer dia do ano e quanto antes ${ }^{246}$.

A partir do final do século VI e início do século VII já se tem um ritual de iniciação claramente organizado para as crianças ${ }^{247}$. O sentido de iniciação cristã está radicalmente comprometido. O processo catecumenal é substituído pela sacramentalização. Comprometida também está a relação liturgia-catequese ${ }^{248}$. No século $\mathrm{V}$ ela ainda manifesta certa vitalidade, mas definha-se e quase desaparece nos século VI. A partir do final do século VIII, os escrutínios caem em desuso. Ou o que é pior, tudo reunido numa única celebração: o ingresso no catecumenato, os exorcismos, a celebração da manhã do sábado santo e o batismo ${ }^{249}$.

No segundo milênio, entre as principais mudanças está a dissociação da eucaristia em relação ao batismo e à confirmação, proveniente do batismo de crianças $^{250}$, e a separação do batismo e confirmação ${ }^{251}$. Posteriormente, tal separação será ainda mais grave: passagem da crisma para depois da primeira

\footnotetext{
${ }^{246}$ BASURKO. X. De Gregório Magno a Gregório VII (590-1073). In: BOROBIO, D. (Org.). A celebração na Igreja 1, op. cit., pp. 90-91.

${ }^{247}$ Trata-se do Ordo Romanus XI. Cf. SILVA, A. J. A iniciação cristã em sua evolução histórica, op. cit.

${ }^{248}$ Para uma melhor visão do catecumenato nos séculos subsequentes, confira o belo trabalho de SILVA, A. J. A iniciação cristã em sua evolução histórica, op. cit.

${ }^{249}$ Cf. Ibid.

250 "Não que essa conseqüência fosse necessária, pois a Igreja Oriental conserva, até hoje, a comunhão batismal dos bebês. $\mathrm{O}$ adiamento da eucaristia para quando a criança chegasse ao "uso da razão', não pareceu decisão evidente, mesmo na Igreja Latina... Até o século XII a comunhão batismal das crianças de colo era prática generalizada no Ocidente e ainda no século XVI é testemunhada, aqui e ali, seja na prática, seja em ritos que são um resquício da prática antiga (assim, por exemplo, dar um pouco de vinho não-consagrado à criança, no final da celebração). TABORDA, F. Nas fontes da vida cristã, op. cit., p. 23, citado por SILVA, A. J. A iniciação cristã em sua evolução histórica, op. cit.

251 "A separação da crisma, no conjunto da iniciação cristã, se deu bem antes, sem qualquer razão teológica. Quando o batismo passou a ser administrado nas Igrejas rurais, sem a presença do bispo, foi preciso optar: ou transferir para a competência do presbítero a totalidade da iniciação, ou separar o banho batismal dos ritos pós-batismais realizados pelo bispo. A Igreja Oriental preferiu a primeira opção. A Latina ficou com a segunda". TABORDA, F. Nas fontes da vida cristã, op. cit., p. 23, citado por SILVA, A. J. A iniciação cristã em sua evolução histórica, op. cit.
} 
eucaristia $^{252}$. Portanto, perde-se no segundo milênio a unidade dos sacramentos da iniciação cristã, tão central para a Igreja dos primeiros séculos.

\section{2}

\section{A restauração do catecumenato e o Ritual de Iniciação Cristã de Adultos (RICA)}

O objetivo dos itens a seguir já foram anunciados no capítulo anterior, em cuja ocasião apresentávamos o novo paradigma da iniciação à vida cristã em andamento. Dizíamos que o catecumenato assume uma importância fundamental nesse processo, tornando-se inclusive referencial para as variadas formas de educar na fé. É nesta perspectiva que apresentaremos a recuperação catecumenal e seus elementos constitutivos, contidos em seu livro litúrgico denominado Ritual de Iniciação Cristã de Adultos (RICA). Importa perceber que o catecumenato não é uma peça isolada, mas ao contrário, se encontra profundamente inserido nesta conjuntura de redescoberta dos caminhos da transmissão da fé.

\section{2.1}

\section{A restauração do Catecumenato}

Após séculos de inverno eclesial no tocante à iniciação cristã, ou se preferirmos, de um longo período caracterizado pelo catecumenato social, embora tentativas de revitalização foram ensaiadas ${ }^{253}$, é a partir do século XX que sopram os primeiros ventos significativos de resgate do catecumenato. Em 1878, o cardeal Charles Martial Lavigerie, fundador dos Padres Brancos, esforça-se para introduzi-lo na África. A partir desse impulso, o catecumenato chega a algumas Igrejas jovens da África e da Ásia. No contexto europeu, é na França, especialmente em Lião e Paris, que se dão os primeiros passos para sua implantação.

\footnotetext{
${ }^{252} \mathrm{O}$ espaçamento nas visitas pastorais do bispo, devido à distância, dificuldade de acesso a lugares longínquos, comodismo episcopal ou qualquer outro motivo, levou a permitir o acesso à eucaristia antes da confirmação, desfazendo a ordem dos sacramentos da iniciação ${ }^{252}$. Cf. TABORDA, F. Nas fontes da vida cristã, op. cit., p. 23, citado por SILVA, A. J. A iniciação cristã em sua evolução histórica, op. cit.

${ }^{253}$ Para um maior aprofundamento sobre a tentativa de renovação do catecumenato a partir da Idade Moderna, tanto nos países de missão como nos de antiga tradição cristã, cf. FLORISTÁN, C. Catecumenato: história e pastoral da iniciação, op. cit., pp. 108-127; ALBERICH, E. e BINZ, A. Formas e modelo de catequese com adultos, op. cit., pp. 27-28.
} 
Embora tenham sido imprescindíveis as experiências anteriores ao Vaticano II para a revitalização da instituição do catecumenato, sua referência fundamental é o aggiornamento eclesial promovido pelo Concílio, que percebe o descompasso entre as evoluções da modernidade e a eclesiologia reinante. No confronto com a modernidade, a Igreja dá-se conta do fim da cristandade, o que a faz repensar, dentre muitas questões, os caminhos de iniciação à fé cristã. Neste contexto, há de reconhecer a contribuição do movimento de renovação litúrgica ${ }^{254}$, que devolve à liturgia sua identidade, rompendo assim com aquele ritualismo ao recuperar a esquecida compreensão teológica dos sacramentos, agora não mais numa ótica mágica e ritualista, e sim como comunicação da salvação de Deus ao povo ${ }^{255}$. Neste clima de aggiornamento, portanto, o Vaticano II pede oficialmente a restauração do catecumenato. Em vários de seus documentos o Concílio expressa tal desejo ${ }^{256}$, mas é a constituição conciliar Sacrossanctum concilium que enfaticamente ordena sua restauração, a ser organizado em etapas, celebrados com seus ritos, conduzindo à celebração dos sacramentos:

\footnotetext{
Restaure-se o catecumenato dos adultos, com vários graus (...) de modo que o tempo do catecumenato, dedicado á conveniente instrução, possa ser santificado por meio de ritos sagrados que se hão de celebrar em ocasiões sucessivas ${ }^{257}$.
}

Outros documentos eclesiais enfatizam igualmente a importância do retorno do catecumenato para a evangelização dos adultos. O decreto sobre a Evangelização dos povos, Ad Gentes, assim se expressa: o catecumenato não é mera exposição de dogmas e preceitos mas uma formação de toda a vida cristã e uma aprendizagem efetuada de modo conveniente, por cujo meio os discípulos se unem a Cristo seu mestre" (AG, n. 14).

\footnotetext{
${ }^{254}$ Para uma visão detalhada da reforma litúrgica, cf. PASQUALETTI, G. Reforma litúrgica. In: SARTORI, D. e TRIACCA A. M. (orgs.) Dicionário de Liturgia, op. cit. Destacam-se a participação ativa e consciente de todos os fiéis (SC, 79), a adaptação da liturgia à mentalidade e tradição dos diversos povos (SC, 37); o uso da língua vernácula (SC, 36); a centralidade da Palavra de Deus na liturgia (SC, n. 24).

${ }^{255}$ A já citada constituição sobre a sagrada liturgia, Sacrossantum Concílium, condensa tal conquista. Cf. AUGÉ, M. AUGÉ, M. Liturgia. História, celebração, teologia e espiritualidade. São Paulo: Ave Maria, 1992, p. 59 ss; PASQUALETTI, G. Reforma litúrgica, op. cit. In: SARTORI, D. e TRIACCA A. M. (org.). Dicionário de Liturgia, op. cit. p. 994.

${ }^{256} \mathrm{SC}, 64-68 ; \mathrm{LG}, 14 ; \mathrm{CD}, 14,3 ; \mathrm{PO}, 5 ; 6,4 ; \mathrm{AG}, 13$ e 14.

${ }^{257}$ SC, n. 64; 66 e 71; CD, n. 14.
} 
Buscou-se na experiência dos Padres da Igreja a inspiração para transmitir e educar na fé, cientes e atentos às necessárias adaptações aos tempos atuais. Longe de ser um saudosismo, trata-se de busca de inspiração e esforço de volta ao espírito das origens, quando a Igreja era essencialmente missionária. Trata-se de uma escolha dotada de sabedoria, buscar retomar esse tesouro da original e rica experiência de fé dos priimeiros séculos.

Outra observação necessária, que em nossa tese terá um peso decisivo, é o fato da intuição catecumenal ultrapassar o terreno específico da catequese, ou seja, o conjunto eclesial pode beneficiar-se com seu retorno, de modo especial o institucional paroquial. Inspirados em sua pedagogia e em seus elementos pastorais, abrem-se possibilidades múltiplas de renovação em inúmeros âmbitos eclesiais. Nesta perspectiva, é significativo que o adjetivo catecumenal tem sido nesses últimos anos símbolo de busca de renovação e de autenticidade cristã ${ }^{258}$.

Não obstante tamanha riqueza, Boróbio alerta para um perigo que ronda o agente de pastoral ao se encantar com o projeto do catecumenato nas mais diversas comunidades eclesiais. Por vezes, a inflação do uso ‘catecumenato' gera ambigüidades. De um lado, ele é uma peça fundamental na renovação pastoral; de outro, tem-se utilizado o termo 'catecumenato', quando na verdade trata-se de uma simples preparação catequética intensiva, sem acompanhar a dinâmica, estrutura e metodologia de um verdadeiro processo catecumenal. Quando tudo é catecumenato, nada é catecumenato. Para que seja de fato um noviciado na vida cristã, urge respeitar seu dinamismo, seu processo de crescimento e aprendizado $^{259}$. Dito diferente, se o catecumenato inspira outras formas de iniciação à vida cristã, se é ele o modelo de toda catequese, podendo igualmente ser fator de renovação eclesial em sentido mais amplo, não se pode sem mais ser confundido com as realidades por ele inspiradas. Daí a importância de conhecer profundamente sua metodologia e seus pressupostos, a partir dos quais, outras realidades serão iluminadas.

\section{2 .2}

\section{Ritual de Iniciação Cristã de Adultos (RICA)}

\footnotetext{
${ }^{258}$ BOROBIO, D. La iniciacion cristiana, op. cit., pp. 536-537.

${ }^{259}$ Ibid., p. 533.
} 
Em cumprimento ao pedido do Concílio Vaticano II de restaurar o catecumenato, foi elaborado, pela Congregação para o Culto Divino, o Ritual de Iniciação Cristã de Adultos (RICA), cuja publicação data de 6 de janeiro de $1972^{260}$. O catecumenato tem no livro litúrgico $\mathrm{RICA}^{261}$ sua referência obrigatória, cuja publicação situa-se dentro da reforma litúrgica, no contexto do aggiornamento do Vaticano $\mathrm{II}^{262}$.

Trata-se de um livro litúrgico teológico catequético ${ }^{263}$. De uma completude impressionante, o RICA oferece a estrutura metodológica do itinerário de iniciação à vida cristã ${ }^{264}$, desde seu primeiro contato com a Igreja até a plena introdução nela, pelos sacramentos da iniciação, celebrados conjuntamente, dentro do possível, na noite da Vigília Pascal. Elementos como a teologia da iniciação cristã, símbolos e celebrações litúrgicas, as etapas do processo, com seus tempos e ritos celebrativos que marcam a passagem de uma etapa para outra estão presentes no Ritual da Iniciação ${ }^{265}$. Ele busca recuperar e contextualizar os elementos que se encontram na Igreja primitiva, de modo especial na Tradição Apostólica de Hipólito de Roma. De acordo com o especialista no assunto, Francisco Lelo, “a

\footnotetext{
${ }^{260}$ No Brasil, o RICA foi editado em 1974. O grande desafio continua sendo sua implantação e conscientização. Há dioceses onde ele é devidamente assumindo, enquanto que em outras ele é pouco conhecido e valorizado.

${ }^{261}$ CONFERÊNCIA NACIONAL DOS BISPOS DO BRASIL. Ritual da Iniciação Cristã dos Adultos (ritual romano renovado por decreto do Concílio Vaticano II, promulgado por autoridade do papa Paulo VI). 3. Ed. São Paulo, 1980. Em português teve uma reedição em 2001, elaborada pelo setor liturgia da CNBB.

${ }^{262}$ LIBÂNIO, J. B. Concílio Vaticano II. Em busca de uma primeira compreensão. São Paulo: Loyola, 2005, p. 52. Vale a pena ressaltar a importância da constituição Sacrossanctum concilium que liberta a liturgia do ritualismo e lhe dá uma perspectiva mais teológica. Há, contudo, de reconhecer que o Ritual foi fruto não somente das decisões expressas na Constituição Sacrosanctum Concilium sobre a sagrada liturgia e no decreto Ad gentes, sobre a atividade missionária da Igreja e em outros documentos do Concílio, mas buscou recolher duas experiências catecumenais: a iniciação cristã da Igreja patrística e outra anterior ao Concílio, isto é, o esforço catecumenal que surgiu, sobretudo, na França e em alguns países missionários. Cf. FLORISTÁN, C. Catecumenato: história e pastoral da iniciação, op. cit., pp. 162 -163.

${ }^{263}$ O RICA não oferece o conteúdo catequético propriamente dito, como é comum nos manuais de catequese.

${ }^{264} \mathrm{O}$ texto é composto por um conjunto de observações gerais (cinco subtítulos e trinta e cinco números), mais quatro capítulos que abordam a caminhada nas diversas situações para a iniciação de adultos, um capítulo para a iniciação de crianças em idade de catequese, outro capítulo com texto da Escritura referente à iniciação, e um apêndice sobre a iniciação cristã dos adultos no âmbito ecumênico. Cf. MERLOS, F. O Ritual de Iniciação Cristã de Adultos (Rica): uma leitura teológica. In: Revista de Catequese. São Paulo: Unisal ano 25, n 99, julho/setembro, 2002, pp. 3435. O primeiro capítulo intitulado "Ritos do catecumenato em torno de suas etapas" apresenta a forma típica de iniciar na fé um adulto não batizado. Há uma nova edição brasileira, que acrescenta um sétimo capítulo.

265 Cf. ORMONDE, D. Vale a pena os catequistas conhecerem o catecumenato. In: CONFERÊNCIA NACIONAL DOS BISPOS DO BRASIL. Segunda Semana Brasileira de Catequese. Com adultos, catequese adulta, op. cit.
} 
escolha é fruto da convicção de que essa antiga disciplina não estava ligada a uma determinada época histórica, mas tinha um valor perene, mesmo se a sua prática em nossos dias supõe uma real adaptação de ritos e fórmulas" ${ }^{\text {266 }}$.

Alguns princípios tornam-se irrenunciáveis ao fazer uso da proposta metodológica catecumenal expressa no Ritual. Ele não quer ser um livro de receitas a serem aplicadas ao pé da letra. Trata-se de proposta e orientações que exigem adaptações. O Livro litúrgico abre possibilidades a adaptações e elaboração de itinerários diversos, segundo as necessidades e as circunstâncias, conservando o essencial e garantindo a qualidade do processo ${ }^{267}$. O Ritual insiste na importância de levar em consideração o contexto vital de cada pessoa. Concluise com isso que a humanidade é irrenunciável no itinerário catecumenal, isto é, chega-se à maturidade da fé com toda a carga de humanidade, e não apesar dela $^{268}$.

\subsection{3}

\section{Destinatários do catecumenato e as diversas formas de percorrer o caminho catecumenal}

A pergunta pelos interlocutores do catecumenato, ainda que já tenha sido parcialmente respondida, merece uma reflexão maior em nossa pesquisa. Prioritariamente ele se destina aos adultos, que na realidade brasileira e da América latina são majoritariamente aqueles já batizados, sem com isso terem realizada uma genuína iniciação à vida cristã, o que justifica falarmos também de reiniciação à vida cristã, entendida como a prática pastoral com os adultos batizados que, tendo se afastado da fé e da Igreja, em determinado momento, sentem o desejo de 'refazer o caminho', ou de completar uma iniciação cristã que ficou incompleta ou insuficiente.

\footnotetext{
${ }^{266}$ LELO, A. F. A iniciação cristã: catecumenato, dinâmica sacramental e testemunho, op. cit., p. 36.

${ }^{267}$ As adaptações do Ritual a serem feitas pelas conferências dos bispos (RICA 64-65); igualmente adaptações que competem aos ministros (RICA 67). Chama a atenção a liberdade deixada pelo ritual a quem o utiliza, sobretudo no tocante fórmulas, orações, exortações.

${ }^{268}$ Muito significativo é a definição da palavra contexto, oferecida pelo catequeta Francisco Merlos. "O contexto é o espaço das raízes vitais mais profundas que dão ao ser humano uma identidade, situando-o no horizonte da justa compreensão. O contexto é o lugar do enraizamento, da pertença, dos significados básicos da vida, das experiências fundamentais, das questões existenciais às quais não se renuncia completamente pelo fato de iniciar um novo projeto de vida". MERLOS, F. O ritual de iniciação cristã de Adultos (RICA), op. cit. In: Revista de Catequese, ano 25, n. 99, julho/setembro, 2002, op. cit., p. 35.
} 
Embora o catecumenato nos primórdios do anúncio do Evangelho dirigiase aos adultos não batizados que desejavam se tornar cristãos, e apesar de ser esse o sentido estrito da palavra catecúmeno, torna-se obsoleta, dentro dos novos contextos de aguda secularização, enquadrar na metodologia catecumenal tão somente os não batizados, quando na realidade se vive em meio a uma multidão de 'batizados não iniciados', expressão já bastante comum nas abordagens do assunto. É nesta perspectiva que o RICA contempla igualmente outros interlocutores no processo catecumenal, como bem pode se perceber na estruturação de seus seis capítulos. No primeiro capítulo, o Ritual da Iniciação apresenta a ritualidade completa do catecumenato, em suas etapas e tempo, ou seja, o itinerário metodológico de iniciar na fé um jovem ou adulto não batizado. A partir desta estrutura elementar, sensível à atual realidade sócio cultural religiosa, o Ritual tem uma proposta aos mais diversos interlocutores, adaptandose às situações diversas e às circunstâncias particulares. Ganha destaque o capítulo IV, o qual, com critérios pastorais, material litúrgico, reflexões teológicas, apresenta o itinerário para a 'preparação para a confirmação e a eucaristia de adultos que, batizados na infância, não receberam a devida catequese'. Vale a pena reafirmar que tal realidade constitui o grande desafio pastoral na atualidade, o que faz este capítulo do RICA ser mais significativo e próximo ao nosso contexto.

Pode-se afirmar que o livro litúrgico oferece basicamente duas possibilidades de fazer o percurso catecumenal: catecumenato pré-batismal e pósbatismal. Enquanto o primeiro è direcionado aos adultos não batizados, o segundo contempla as demais realidades, sejam crianças na idade da catequese, ou jovens e adultos que por algum motivo ainda não chegaram à maturidade cristã. Deixemos que o próprio RICA discorra: 'Adultos que, pela primeira vez, se dirigem à Igreja; 'Adultos que, batizados na infância, não receberam a devida catequese' (RICA 295-305); 'Crianças em idade de catequese' (RICA 306-369) ${ }^{269}$.

O Ritual quer concretizar o catecumenato como oportunidade de iniciação à vida cristã, através de um completo itinerário, seja aos não iniciados, seja como

269 Trata-se de uma adaptação do primeiro capítulo à realidade infantil. São crianças que já alcançaram o uso da razão, mas que ainda não podem ser consideradas adultas, pois "tendo apenas conhecimento próprios de sua idade, dependem dos pais ou responsáveis e sofrem profunda influência dos companheiros e da sociedade" (RICA, 306). 
chance de redescoberta de Jesus Cristo aos já batizados, que desejam retornar ou aprofundar sua relação com o Mistério ${ }^{270}$.

\section{3}

\section{Elementos eclesiológicos e pastorais da pedagogia catecumenal}

Antes de apresentar as etapas do processo catecumenal e o específico de cada uma delas, traçaremos algumas características centrais, como que dimensões transversais que perpassam todo o processo da iniciação cristã catecumenal.

\subsection{1}

\section{A progressividade da iniciação à vida cristã}

Se é verdade que não se nasce cristão, mas se torna, também é certo que não se torna cristão de um dia para o outro, sob pena da conversão não firmar raízes mais profundas, colocando em xeque a própria dinâmica da conversão. A graça, por não se sobrepor à natureza humana, precisa de tempo para trabalhar. Assim como a chuva que cai, fecunda a terra e não volta sem dar frutos, o

\footnotetext{
${ }^{270}$ Muitos outros documentos eclesiais, em sintonia com o RICA, reafirmam os diferentes destinatários da iniciação cristã catecumenal. EN afirma haver "grande número de pessoas que receberam o batismo, mas vivem a margem de toda vida cristã' (EN, 52). Trata-se dos não praticantes, de "toda uma multidão, numerosa hoje em dia, de batizados que, em grande parte, não renegaram formalmente seu batismo, mas estão totalmente à margem do mesmo e não o vivem" (EN, 56). A Catechesi Tradendade fala dos quase catecúmenos, isto é, "dentre todos os adultos que têm necessidade de catequese, um solícito pensamento pastoral e missionário me vai agora para aqueles que, nascidos e educados em regiões ainda não cristianizadas, nunca puderam aprofundar a doutrina cristã, que as circunstâncias da vida alguma vez lhes permitiram encontrar; vai também para aqueles que na sua infância receberam uma catequese correspondente a tal idade, mas que em seguida se afastaram de toda a prática religiosa e se acham na idade madura com conhecimentos é dizer num ambiente sociologicamente cristão, nunca foram educados na sua fé e são, chegados à idade adulta, verdadeiros catecúmenos" (CT, 44). Christifideles laici de 1988 fala de "uma catequese pós-batismal, em forma de catecumenato, através de uma ulterior proposta de certos conteúdos do Ritual religiosos prevalentemente infantis; vai depois para aqueles que se ressentem de uma catequese precoce, mal orientada e mal assimilada; e vai por fim para aqueles que, embora nascidos em países cristãos, que o mesmo da Iniciação Cristã dos Adultos, destinados a permitir uma maior compreensão e vivência das imensas e extraordinárias riquezas e da responsabilidade do Batismo recebido" (ChL, n. 61). O Diretório Geral de Catequese, 1997, trabalha com maestria as diversas formas de catequese e portando os destinatários da iniciação cristã, por meio de catecumenato pré-batismal e pós -batismal ou quase batismal. O capítulo quarto do documento de estudo da $47^{\mathrm{a}}$ Assembléia da CNBB, "Iniciação à Vida Cristã", aborda os destinatários do processo de iniciação a vida cristã da seguinte foram: $\mathrm{A}$ - adultos e jovens não batizados; B - adultos e jovens batizados que desejam completar a iniciação cristã; C - adultos e jovens com prática religiosa, mas insuficientemente evangelizados; D - pessoas de várias idades marcadas por um contexto desumano ou problemático; E - grupos específicos em situações variadas; $\mathrm{F}$ - adolescentes e jovens; $\mathrm{G}$ - crianças não batizadas e inscritas na catequese; $\mathrm{H}$ crianças e adolescentes batizadas que seguem o processo tradicional de iniciação crista. CONFERÊNCIA NACIONAL DOS BISPOS DO BRASIL. Iniciação à Vida Cristã: um processo de inspiração catecumenal. Brasília: CNBB, 2009 (Estudos da CNBB 97), n. 129.
} 
catecumenato dispõe de tempo e espaço para integrar os vários componentes da iniciação à vida cristã.

Partindo do pressuposto de que o catecumenato é "verdadeira escola preparatória à vida cristã" (AG, 14), consideramos que a progressividade da féconversão constitui não só a principal característica do catecumenato mas sua própria identidade. Todos os elementos da pedagogia catecumenal visam a aquisição da plena maturidade cristã, que não pode ser conquistada a não ser através de um gradual itinerário formativo. O Ritual de Iniciação de Adultos entende a iniciação como um processo dinâmico e progressivo que se é percorrido "gradualmente" (RICA, 4), "se acomoda ao caminho espiritual dos adultos, que é muito variado" (RICA, 5). Consta de "graus ou etapas" (RICA, 6-7) a serem percorridos. Onde melhor se evidencia o caráter progressivo da proposta do catecumenato é, portanto, na sua própria estrutura, marcada por tempos e etapas sucessivos.

Cada período é tempo de busca, de escuta, de oração, de empenho de conversão, é o momento no qual o candidato é ajudado a descobrir e a responder ao chamado de Deus e ao plano de salvação do Senhor ${ }^{271}$.

$\mathrm{Na}$ análise de Lelo, "na metodologia da iniciação, como se deduz, a palavra 'estrutura' sublinha que os elementos do processo iniciatório estão estreitamente unidos, formando um conjunto" ${ }^{272}$. Conclui Merlon

O fato mesmo de denominá-lo em latim de Ordo initiationis christianae adultorum (Oica) denota seu caráter de ordenamento ou itinerário dinâmico, vinculado mais do que a aspectos rituais, a verdadeiros processos vitais que busquem introduzir gradualmente o discípulo de Jesus na mais pura essência da vida cristã, configurada pelos valores centrais do Evangelho ${ }^{273}$.

Há tempo para descobrir, tempo para responder, tempo para a maturação e aprofundamento, tempo para saborear aquilo no qual se foi tornado. Cada momento do itinerário percorrido conduz a um novo salto, ou se quisermos, a um maior aprofundamento no crescimento da fé. A título de exemplificação, o tempo

${ }^{271}$ CAVALLOTTO, G. Itinerari catecumenali per uma chiesa missionária, op. cit., p. 365.

${ }^{272}$ LELO, A. F. A iniciação cristã: catecumenato, dinâmica sacramental e testemunho, op. cit., $p$. 36.

${ }^{273}$ MERLOS, F. O ritual de iniciação cristã de Adultos (RICA), op. cit.. In: Revista de Catequese. São Paulo: Unisal, ano 25, n. 99, julho/setembro, 2002, op. cit., p. 34. 
do catecumenato quer levar ao amadurecimento aquelas disposições apresentadas no pré-catecumenato, e assim sucessivamente, o que significa já no início do processo encontrarmos a marca da progressividade, a passagem de uma primeira adesão a uma entrega mais consciente à proposta cristã, celebrada liturgicamente. Assim, todas as celebrações catecumenais são densas de significado no tocante à progressividade da maturidade cristã. Elas expressam com propriedade não apenas os aspectos litúrgicos e pastorais, mas teologicamente revelam o crescimento na maturidade cristã, ao celebrar o nível de maturidade cristã conseguido no período anterior, ao mesmo tempo em que introduz o catecúmeno na nova fase da aventura do crescimento espiritual ${ }^{274}$.

Outro aspecto significativo subjacente ao caráter da progressividade da maturação da fé é o fator antropológico-teológico, que leva em consideração a individualidade de cada pessoa. A atenção ao ritmo de cada pessoa atesta que o ser humano é a prioridade no catecumenato ${ }^{275}$. Dimensões como abertura, descoberta, resposta, crescimento, consciência são eminentemente pessoais e intransferíveis, que fogem, conseguintemente, a toda pré-determinação temporal. O Ritual, atento a isso, não estipula tempo para a concretização da iniciação cristã catecumenal, respeitando a íntima relação entre ação de Deus e o tempo-resposta do catecúmeno ${ }^{276}$. A pedagogia divina acha lugar na natureza humana, que é chamada a responder ao apelo divino a partir de seus ritmos intelectuais e afetivos, e condicionamentos internos e externos ${ }^{277}$.

Enfim, se todo crescimento humano é progressivo, gradual e passa por diversos estágios, a iniciação catecumenal não foge dessa dinâmica ${ }^{278}$. Por tratar-

\footnotetext{
${ }^{274}$ CAVALLOTTO, G. Itinerari catecumenali per uma chiesa missionária, op. cit., p. 365.

275 ALBERICH, E.; BINZ, A. Formas e modelos de catequese com adultos, op. cit., p. 45.

${ }^{276}$ Algumas imagens ajudam a melhor visualizar a dinâmica da progressividade da fé cristã: a imagem bíblica da marcha, desenvolvida por Orígenes, na qual ele compara o catecumenato ao êxodo do povo hebreu que entre o mar vermelho (entrada no catecumenato) e o Rio Jordão (batismo) avança junto a um grupo para receber a Palavra de Deus e se esforça para vivê-la; a imagem da gestação, muito caro para os padres do quarto século, que viam o catecúmeno como uma criança que foi concebida no útero da Igreja, até que estivesse pronto para entrar no mundo do batismo; a imagem militar do noviciado no período de formação que os jovens recrutas militares tem de percorrer antes de tomar seu juramento e ir para a batalha. Cf. LAURENTIN A.; DUJARIER M. Catéchuménat. Données de h'histoire et perspectives nouvelles (Vivante Liturgie 83). Paris, 1969, pp. 52-54, citado por DUJARIER M. A survey of the history of the Catechumenate, op. cit., p. 24.

${ }^{277}$ Cf. FALSINI, R. l'Iniziazione Cristiana e suoi sacramenti, op. cit., p.15.

${ }^{278}$ DUJARIER, M. The Rites of Christian Initiation: historical and pastoral relections. Chicago: Sadlier, 1979, p. 21.
} 
se de uma iniciação global à vida cristã, o objetivo a que se propõe a gradualidade catecumenal aponta para o desejo de atingir todas as dimensões da vida cristã: a adesão pessoal ao Deus de Jesus Cristo, a compreensão e acolhida do plano de salvação, a descoberta do mistérios centrais da fé e das verdades fundamentais do cristianismo, a aquisição de uma verdadeira mentalidade cristã, o desenvolvimento da capacidade orante, a iniciação a vida da comunidade eclesial e em particular a sua experiência litúrgica, a abertura à vida apostólica e missionária, e não menos importante, a formação à vida caritativa e animação da ordem social $^{279}$.

\subsection{2}

\section{Catecumenato e a comunidade eclesial}

Outro aspecto a ser destacado como constitutivo da proposta catecumenal é a dimensão comunitária da fé. Mais do que uma pastoral da comunidade, o catecumenato se entende como a comunidade a serviço da iniciação cristã, o que significa o envolvimento de toda a comunidade na formação dos novos cristãos.

\subsubsection{1}

\section{A centralidade da comunidade no processo de iniciação cristã}

Antes de entrar no comunitário expresso pelo RICA, torna-se oportuno reforçar teologicamente a importância da dimensão comunitária na iniciação à vida cristã. A comunidade é por excelência lugar de iniciação cristã. Não se chega a ser cristão sozinho, assim como não se permanece cristão em solidão. Segundo Libânio, crer na igreja, signigica ao mesmo tempo crer em Igreja, sendo uma comunidade eclesial ${ }^{280}$ Em outras palavras, “a iniciação é um encontro da Igreja com o iniciado e deste com a Igreja. A comunidade de fé há de ser sempre a origem, o lugar e a meta da iniciação cristã"281.

\footnotetext{
${ }^{279}$ Cf. CAVALlOTTO, G. Itinerari catecumenali per uma chiesa missionária, op. cit., p. 370. Rosemary Fernandes da Costa apresenta os seguintes elementos a serem trabalhados no percurso catecumanal: "acolhida, oração pessoal e comunitária; escuta e hermenêutica da Palavra de Deus; ritos, celebrações litúrgicas e sacramentais; acompanhamento pessoal e comunitário; leitura e hermenêutica existencial, orientação ética e conversão processual; missão e testemunho". COSTA, R. F. A mistagogia e a Iniciação Cristã de Adultos, op. cit., p. 110.

${ }^{280}$ LIBANIO, J. B. Eu creio, nós cremos, op. cit., p. 253.

${ }^{281}$ LEÓN OJEDA, F. J. La iniciatión Cristiana. Publicationes CELAM Bogotá, Missión Continental 2, p. 33.
} 
As comunidades eclesiais são fontes da catequese. A pedagogia catequética só é eficaz à media em que a comunidade se tornar referência concreta e exemplar para a caminhada de fé dos indivíduos. "A comunidade cristã é em si mesma catequese viva" (DGC n 140). Lapidar a afirmação de Fossion. "Em certo sentido, ela (a catequese) nada mais faz senão explicar, com todos os recursos da Tradição, aquilo que a comunidade vive, aquilo por que ela vive, para que possa servir de referência"282. O DGC afirma a mesma certeza. (A comunidade) "por aquilo que é, anuncia, celebra, opera, permanece sempre lugar vital, indispensável e primário da catequese" (DGC 141).

A iniciação à vida cristã somente chega ao seu escopo através de dois passos fundamentais e inseparáveis entre si: o pessoal e o comunitário. A dimensão pessoal requer a livre adesão à iniciativa divina, enquanto que a dimensão comunitária recorda que a resposta ao chamado divino não se realiza fora de uma comunidade eclesial. O objetivo da iniciação à vida cristã é o mergulho sacramental-ontológico e existencial no mistério pascal. Longe de ser uma ação meramente individual, tal mergulho atinge a dimensão pessoal e coletiva do cristão. Se ninguém pode crer no meu lugar, pois se trata de uma decisão pessoal e livre, por outro lado, creio com, isto é, partilhando a fé com homens e mulheres que professam a mesma confiança no Deus de Jesus Cristo. "Quando falamos de Sacramento e de sacramentos da iniciação, o fazemos em referência ao grande sacramento, que é a comunidade cristã" ${ }^{283}$. Entender os sacramentos da iniciação cristã associados ao sacramento da Igreja é uma acertada intuição para romper com o individualismo religioso e sacramental, fruto de uma concepção individualista da salvação.

Os Documentos conciliares reafirmam a beleza de viver a experiência salvífica em uma comunidade concreta. Gaudium et Spes assim se expressa:

Como Deus não criou os homens para viverem isoladamente, mas formarem uma união social, assim também lhe agradou santificar e salvar os homens não isoladamente, excluindo qualquer conexão mútua, mas constituindo-os num povo que $\mathrm{O}$ reconhecesse na verdade e $\mathrm{O}$ servisse santamente. Deus escolheu os

${ }^{282}$ FOSSION. La catéchèse dans le champ de la communication: sés enjeux pour l'inculturation de la foi. Paris: Cerf, 1990, p. 354, citado por ALBERIC, Catequese evangelizadora, op. cit., p. 274 .

${ }^{283}$ VELAS, J. A. Reiniciación Cristiana, respuesta a unm bautismo 'sociológico', op. cit. p. 126. 
homens não como indivíduos somente, mas como membros de uma comunidade" (GS 32).

O Documento da Conferência de Aparecida, por sua vez, nos recorda que a fé cristã é sempre mediatizada pela Igreja. "Diante da tentação, muito presente na cultura atual, de ser cristão sem Igreja e das novas buscas espirituais individualizadas, afirmamos que a fé em Jesus Cristo nos chega através da comunidade eclesial" (DAp 256). Para o mesmo Documento "a vida em comunidade é essencial à vocação cristã” (DAp 179).

A comunidade pode parecer à primeira vista uma contradição à fé, uma vez que esta é ato livre, contudo ela confirma a própria dinâmica da liberdade da fé, pois esta, sendo algo íntimo e pessoal, remete ao outro. Só se é livre com os outros e para os outros, no confronto com o outro. Feitas essas observações, pretendemos sondar a relação entre iniciação à vida cristã catecumenal e comunidade, expressa no Ritual de Iniciação de Adultos.

\subsubsection{2}

\section{A dimensão comunitária no Ritual de Iniciação Cristã de Adultos}

O RICA oferece uma proposta pastoral que vai ao encontro do que entendemos ser o maior desafio eclesial na atualidade: iniciar na fé e na vida comunitária de fé, como momentos inseparáveis de um único processo evangelizador, ou seja, transmitir a fé cristã e atrair para a vida em comunidade não são tarefas distintas.

$\mathrm{O}$ catecumenato exige o envolvimento e responsabilidade de toda a comunidade no processo da iniciação, que na sua vocação de maternidade espiritual gera e alimenta os novos filhos na fé. A caminhada catecumenal se apresenta como um único caminho a ser percorrido com mão dupla, em direção ao Mistério pascal: de um lado, o comprometimento de toda a comunidade no processo formativo do catecúmeno, e da parte deste, o caminhar em direção ao engajamento pleno na comunidade de fé. Ambos, comunidade e catecumenato, necessitam-se mutuamente para a maturidade da fé. Ambos, comunidade e catecúmeno, dão e recebem ${ }^{284}$.

\footnotetext{
${ }^{284}$ DUJARIER, M. The Rites of Christian Initiation, op. cit., p. 24.
} 
Trata-se de uma das características mais sublimes do catecumenato, desde os primórdios do seu nascimento. LG assim se expressa sobre o assunto: "Os catecúmenos que, movidos pelo Espírito Santo, solicitam por vontade explícita incorporar-se à Igreja, se unem a ela por este mesmo desejo, e a mãe Igreja já os abraça amorosa e solicitamente como filhos" (LG, 1).

O valor teológico e pastoral dos ritos catecumenais visibilizam a progressiva evolução e crescimento da fé e da pertença à comunidade eclesial. No início do processo as pessoas são denominadas 'simpatizantes', por manifestarem o desejo inicial ou 'curiosidade' de participar de um grupo específico, onde são acolhidos e, paulatinamente vão vislumbrando a beleza da fé cristã. Enquanto 'simpatizantes ou 'candidatos' manifestam a vontade de serem membros da Igreja, que os acolhe oficialmente através do rito de admissão. Já no précatecumenato são convidados aos encontros formais e introduzidos a outros cristãos. Há um envolvimento espontâneo e informal entre membros da comunidade e iniciantes. Tornam-se, então, catecúmenos para o aprofundamento da fé-conversão, e do exercício da vida em comunidade. O catecumenato, segundo período da caminhada, quer ser um tempo mais extenso, no qual a comunidade se envolve mais diretamente na formação dos iniciantes. Após o longo período de vida comunitária, catequese-liturgia, são então eleitos para uma preparação mais intensa. Após esse período, celebram os sacramentos da iniciação e são agregados ao Povo de Deus.

O rito de eleição reveste-se de intenso valor eclesial comunitário, por meio do qual são eleitos para celebrarem os sacramentos e viverem a experiência sacramental juntamente com toda a comunidade. E por fim, recém batizados, a Igreja os acompanha num pleno experimento dos sacramentos na vida de comunidade ${ }^{285}$.

Não é difícil perceber o movimento de convergência para a plena participação eclesial, seja do ponto de vista sacramental, seja do ponto de vista da responsabilidade e compromisso com a comunidade cristã. $\mathrm{O}$ candidato manifesta não somente o interesse pelo Evangelho, mas o busca dentro de uma comunidade eclesial, a qual se compromete em ajudá-lo e acompanhá-lo, sobretudo pelo

${ }^{285}$ VELAS, J. A. Reiniciación Cristiana, respuesta a um bautismo 'sociológico', op. cit., p. 124. 
testemunho de fé. Ad Gentes 14 recorda que pelo desejo de ser incorporar à Igreja, os catecúmenos já estão vinculados a ela.

O catecumenato é eclesial assim como a Igreja é catecumenal. Trata-se do que Alberich denominou de lei estrutural: 'Sem comunidade de fé não existe comunicação da fé'; sem compartilhamento da fé não existe amadurecimento da fé" 286 , pois "o catecumenato é um caminhar da comunidade junto ao catecúmeno e do catecúmeno junto a comunidade" 287 .

A importância da comunidade no processo catecumenal está no fato de sua eficácia depender de comunidades vivas e dinâmicas. A transmissão da fé não depende de rebuscadas teorias ou pedagogias, mas das comunidades vivas que suscitam o desejo de participar de sua vida ${ }^{288}$. A comunidade é, indiscutivelmente, o ponto de referência para o catecumenato. Porém, a existência de comunidades adultas e dinâmicas nem sempre é tão evidente. Não obstante, adverte Boróbio, não se pode cair no círculo vicioso. A inexistência de comunidades verdadeiras não pode paralizar o esforço do projeto catecumenal, nem o contrário: "porque não há comunidades, não há catecumenato, e porque não há catecumanato, não chegamos a comunidades" ${ }^{\text {289 }}$. O processo é dialético, onde prática/consolidação catecumenal e renovação eclesial caminham juntas, se auxiliando mutuamente, como veremos posteriormente. Sem comunidades vivas e atrativas torna-se impossível o crescimento da fé. O investimento no catecumenato, a entrada de novos catecúmenos na comunidade modifica a vida da comunidade e a enriquece, tornando-a dinâmica e atrativa.

\subsubsection{3}

\section{A comunidade eclesial é também catecúmena}

Cabe agora destacar o outro lado da mesma dinâmica eclesial da iniciação cristã catecumenal. A comunidade cristã, ao mesmo tempo em que é sumamente responsável pelo processo de crescimento na fé dos catecúmenos, refaz e aprofunda ela mesma a própria caminhada de fé. A maternidade espiritual da

\footnotetext{
${ }^{286}$ ALBERICH, E. Catequese evangelizadora, op. cit., p. 274.

${ }^{287}$ BOROBIO, D. La iniciaction, op. cit., p. 548.

${ }^{288}$ Cf. RODRIGUEZ, J. M. La catequesis al serviço de la iniciación cristiana. Acoforec: Bogota, 2006.

${ }^{289}$ BORÓBIO, D. La iniciation, op. cit., p. 549.
} 
Igreja é oportunidade para que toda a comunidade dos fiéis renove sua fé, tornando-se sempre mais fecunda, por ser discípula antes de ser missionária. Aqui tocamos num dos pontos centrais da relação comunidade iniciada na fé e catecúmenos-iniciantes. Se a iniciação cristã é um caminhar constante em direção ao mistério de Cristo e da Igreja, a comunidade sente a necessidade de percorrer o itinerário de sua formação permanente juntamente com o catecúmeno. Somente uma Igreja em constante processo de conversão poderá gerar e sustentar na fé novos membros.

Numa palavra mais plausível, a comunidade cristã se reinicia e se renova cada vez que gera, acolhe e acompanha em seu seio novos membros, pois também ela está em constante processo de conversão. A comunidade é ao mesmo tempo agente e destinatário da iniciação cristã. "A catequese conduz à maturação da fé não apenas os catequizandos, mas também a própria comunidade enquanto tal" (DGC, 221). Cada comunidade e cada indivíduo, mesmo que já tenha chegado ao estado de crescimento da fé, sempre precisa se converter para o Senhor e entrar mais profundamente na vida do Deus ${ }^{290}$. Recorda Boróbio que

Na medida em que a comunidade acolhe e colabora com os catecúmenos, nessa medida aparecerá claro a eles o caráter eclesial da iniciação e da confirmação. E nessa medida a iniciação conduzirá a renovação da mesma vida da comunidade e de sua missão no mundo ${ }^{291}$.

Se toda a comunidade é convidada a renovar sua fé no Cristo com os catecúmenos, então também ela precisa e é beneficiada pela força ritual e simbólica dos ritos e com tudo o que eles significam. Por exemplo, os escrutínios que transmitem a força de Deus na luta contra as tentações, fortalecem igualmente a comunidade local. Nas 'Entregas' da Oração do Senhor e do Credo a comunidade pode refletir mais profundamente o significado de tais orações na vida da comunidade. Importante que a Igreja refaça sua caminhada a cada ano ao celebrar o mistério pascal com os eleitos. Nesta dinâmica, a celebração do Batismo dos eleitos ganha significado especial para a renovação de fé de toda a comunidade. Já que a maioria absoluta dos fiéis foi batizado enquanto criança, portanto sem uma preparação mais intensa, a participação do batismo dos

\footnotetext{
${ }^{290}$ DUJARIER, M. A Survey of the History of the Catechumenate, op. cit. In: Becoming a catholic Christian, op. cit. p. 21

${ }^{291}$ BOROBIO, D. Catecumenato para la evangelización, op. cit., p. 25.
} 
catecúmenos torna-se oportunidade de conscientização que a tenra idade não possibilitou.

O catecúmeno não é apenas aquele que recebe a formação, e a comunidade não é apenas a que a oferece. Ambos, comunidade e catecumenato se enriquecem mutuamente no constante processo de iniciação à vida cristã. Os catecúmenos precisam do apoio da comunidade de fé, assim como a comunidade de fé necessita da presença dos catecúmenos para renovar-se continuamente.

A palavra neófito está associada ao percurso percorrido pelo que foi batizado e iniciado na fé sacramentalmente. Mas há de ressaltar que para os padres da Igreja, não apenas os recém batizados e sim todos os fiéis são neófitos. O que justifica tal abrangência é a compreensão de que a conversão e o seguimento a Cristo são um processo permanente, a ser percorrido por toda a vida $^{292}$. Portanto, diante do presente perigo do catecumenato acontecer à margem da vida eclesial, isolado do conjunto das atividades eclesiais, ou entendida como mais uma pastoral ao lado de tantas outras, estamos chamando a atenção para o alargamento da consciência de que toda a comunidade é catecumenal e catecúmena ao mesmo tempo.

\section{4}

\section{O envolvimento da comunidade na iniciação à vida cristã}

Um dos gritantes dilemas da ação evangelizadora está no isolamento das atividades pastorais, cuja tendência é o conjunto não se perceber comprometido com as partes, e essas por sua vez nem sempre se verem dentro da totalidade. A imagem de São Paulo, do corpo eclesial com muitos membros é paradigmática para a proposta de pastoral de conjunto, e no caso do catecumenato, para o múnus catequético e formador de toda a comunidade cristã. Permanece sempre um desafio conscientizar para o protagonismo de toda a comunidade eclesial na formação dos novos cristãos, pois, via de regra tal tarefa é delegada a alguns representantes da Igreja, tradicionalmente chamados catequistas.

${ }^{292}$ Cf. TABORDA, F. Nas fontes da vida cristã, op. cit., p. 25-26. 
A comunidade é o sujeito primordial do ministério pastoral, afirma Francisco Merlos $^{293}$. Na carta de São Pedro há a categórica afirmação de que toda a comunidade é sacerdotal (1 Pd 2, 5), e com diversidade de dons e carismas, segundo são Paulo (1 Cor 12, 4-6). "O epicentro da ministerialidade reside na comunidade crente, que é, ao mesmo tempo, origem, protagonista, lugar e mediadora de todo ato salvador" ${ }^{294}$. O ministério eclesial pertence à comunidade. A natureza ministerial e diaconal da Igreja é inegociável e não se condensa em nenhum de seus membros em particular ${ }^{295}$.

A tarefa de gerar novos filhos compete a toda a Igreja, o que significa que o compromisso com a iniciação cristã não se restringe somente aos catequistas e demais funções e ministérios envolvidos diretamente na iniciação cristã. Ainda que o catecumenato disponha de funções e ministérios específicos, nem por isso a comunidade se dá ao direito de se ausentar no acompanhamento dos novos membros. Os agentes específicos do catecumenato não substituem a participação ativa da comunidade, do mesmo modo que a iniciação cristã não pode ser uma parte da atividade pastoral, mas seu núcleo central.

A proposta catecumenal busca garantir a ministerialidade eclesial de toda a comunidade no processo de iniciação à vida cristã. Muito significativa a imagem da maternidade espiritual da Igreja, já utilizada pelos padres dos primeiros séculos. Recordar a maternidade eclesial significa afirmar que o catecumenato é essencialmente um ministério da comunidade, oriundo do mandato missionário de Cristo e da vocação missionária e batismal da Igreja. "Por essa colaboração a Igreja recebe o título de 'mãe', um título merecido pela sua cooperação no renascimento batismal", afirma Lelo ${ }^{296}$.

Nas palavras do RICA, “o Povo de Deus, representado pela Igreja local, sempre deve entender e manifestar que a iniciação dos adultos é algo de seu e assunto que diz respeito a todos os batizados"(RICA 41) ${ }^{297}$.

\footnotetext{
293 Cf. MERLOS F. O Ritual da Iniciação Cristã de Adultos (RICA), op. cit. In: Revista de Catequese, ano 25, n. 99, julho/setembro, 2002, op. cit., p. 34.

${ }^{294}$ Ibid., p. 36.

295 Ibid., p. 36.

${ }^{296}$ LELO, A. F. A iniciação cristã, op. cit., p. 193.

297 Ad Gentes afirma. “ ... Esta iniciação cristã realizada no catecumenato deve ser obra não apenas dos catequistas ou sacerdotes, mas de toda a comunidade dos fiéis, especialmente dos padrinhos, de forma que desde o começo os catecúmenos sintam que pertencem ao Povo de Deus. Visto que a vida da Igreja é apostólica, os catecúmenos devem igualmente aprender a cooperar
} 
O Ritual é enfático ao pedir o acompanhamento dos já iniciados em todas as etapas do processo da iniciação. Esses devem “ajudar os candidatos e os catecúmenos durante todo o currículo da iniciação: no pré-catecumenato, no catecumenato e no tempo da mistagogia" (RICA, 41). Trata-se, portanto, de um acompanhamento muito próximo no decorrer de todo o tirocínio espiritual do catecúmeno. Pela acolhida, testemunho de vida, orações, vida litúrgica, incentivo, parecer sobre a idoneidade do candidato e outras ações manifestam-se a centralidade da comunidade de fé na formação dos novos membros. É a comunidade que acolhe o candidato oficialmente com o rito de admissão e se compromete em ajudá-lo, sobretudo com orações e testemunho de vida. Trata-se de uma acolhida litúrgico-celebrativa, onde a comunidade local é motivada a estar presente. $\mathrm{O}$ candidato é acolhido numa Igreja concreta, que lhe chama pelo nome e a qual ele responde livremente.

$\mathrm{Na}$ tentativa de especificar a atuação comunitária em cada etapa, o Ritual da Iniciação afirma que no pré-catecumenato todos que são chamados, "em primeiro lugar, anunciar ao mundo, por apalavras e atos, a mensagem de Cristo e comunicar sua graça ${ }^{298}$. Estejam, portanto, prontos a demonstrar o espírito da comunidade cristã e receber os candidatos nas famílias, nas reuniões particulares e mesmo em algumas reuniões comunitárias" (RICA, 41.1); "Quando possível, comparecem às celebrações do catecumenato e tomem parte ativa nas respostas, orações, cantos e aclamações" (RICA, 41,2). "No dia da eleição, visto tratar-se do crescimento da própria comunidade, procurem dar oportunamente uma opinião justa e prudente acerca dos candidatos" (RICA, 41,3). "Na quaresma, tempo de purificação e iluminação, sejam assíduos aos ritos dos escrutínios e das entregas e dêem aos catecúmenos o exemplo de sua própria renovação no espírito de penitencia, fé e caridade. Façam questão de renovar as promessas do Batismo na Vigília Pascal" (RICA, 41.4). "No tempo da mistagogia participem das missas dos neófitos, procurem cercá-lo de afeição e ajudá-lo a se sentirem felizes na comunidade cristã" (RICA, 41,5). Mais especificamente convida para que "Rezem

ativamente; pelo testemunho da sua vida e a profissão da sua fé, na evangelização e na construção da Igreja" (AG 14). Na mesma dinâmica, o DGC afirma: "O Catecumenato batismal é responsabilidade de toda a comunidade cristã (DGC, 91).

298 Cf. CONCILIO VATICANO II. O Apostolado dos leigos: Decreto Apostolicam Actuositatem. 6. ed. Petrópolis; Vozes, 1969 (Documentos Pontifícios, 161) n. 6. 
todos pelos eleitos, para que a Igreja os conduza com ela ao encontro de Cristo" (RICA, 135). A Igreja ouve o testemunho dos padrinhos e catequistas e recebe a confirmação da vontade dos catecúmenos. "Para a Igreja, a eleição é como que o centro de sua solicitude em relação aos catecúmenos" (RICA, 135). Na eleição, todos da comunidade de acordo com sua competência manifeste seu parecer sobre o progresso dos catecúmenos (cf. RICA, 135).

A partir desta sólida base ministerial comunitária, são oferecidas as funções e ministérios específicos que acompanham mais de perto o crescimento do catecúmeno (cf. RICA, 42-48). Destacam-se: Introdutor, cuja função é essencial no início do processo, por ajudar o simpatizante a acolher o dom da fé e iniciar o processo de conversão-maturidade cristã. "O candidato que solicita sua admissão entre os catecúmenos é acompanhado por um introdutor, homem ou mulher, que o conhece, ajuda e é testemunha de seus costumes, fé e desejo" (RICA, 42). Trata-se de uma função muito específica e fundamental no précatecumenato. Por ser ele que coloca as bases para a segundo etapa, no qual atuarão os catequistas. Requer dele grande capacidade de ouvir e dialogar, paz interior e disposição para acompanhar com paciência quem está iniciando o processo da iniciação ${ }^{299}$.

Sua importância não se dá somente da etapa pré-catecumenal. "Seu ofício continua sendo importante quando o neófito, tendo recebido os sacramentos, precisa de ajuda para permanecer fiel às promessas do batismo" (RICA 43, 235). Lamentavelmente é um ministério ainda pouco conhecido e valorizado.

A figura do padrinho igualmente recebe uma incumbência vital. Retomando o Ritual, o Documento da CNBB sobre a Iniciação Cristã afirma:

Entre suas tarefas há o acompanhamento para ajudar o catecúmeno a viver o Evangelho, auxiliá-lo nas dúvidas e inquietações, velar pelo seu crescimento na fé, na fraternidade, na vida de oração, na participação da vida da comunidade e no compromisso com a construção do Reino de Deus ${ }^{300}$.

Deve ser escolhido pelo exemplo de vida, no final da primeira etapa. Deve igualmente conhecer o candidato, e testemunhar sua sinceridade em ingressar no

\footnotetext{
${ }^{299}$ Cf. CONFERÊNCIA NACIONAL DOS BISPOS DO BRASIL. Iniciação à Vida Cristã: um processo de inspiração catecumenal, op. cit. n. 129.

${ }^{300}$ Ibid., n. 132.
} 
catecumenato, dando-lhe o apoio por toda a vida ${ }^{301}$. "É seu dever ensinar familiarmente ao catecúmeno como praticar o Evangelho em sua vida particular e social, auxiliá-los nas dúvidas e inquietações, dar-lhe testemunho cristão e velar pelo progresso de sua vida batismal" (RICA, 43).

Compete ao Bispo ou ao representante dirigir o catecumenato, e de acordo com as possibilidades, presidir a celebração da eleição e dos sacramentos da Iniciação na Vigília Pascal (RICA, 44). Aos presbíteros a principal função é a de

Prestar assistência pastoral e pessoal aos catecúmenos, interessando-se sobretudo pelos que se mostram hesitantes e inquietos; cuidar de sua catequese com o auxilio dos diáconos e catequistas; aprovar a escolha dos padrinhos e ouvi-los e ajudá-los de boa vontade; zelar por uma perfeita e adequada execução dos ritos durante todo o decurso da iniciação" (RICA, 45).

Havendo diáconos, prestam ajuda fundamental no acompanhamento do processo e realização dos ritos e etapas (RICA, 47). E os catequistas, de fundamental importância em todo o processo, além de terem parte ativa nos ritos, "cuidem de que a catequese seja penetrada do espírito evangélico, em harmonia com os ritos e o calendário litúrgicos, adaptada aos catecúmenos e, na medida do possível, enriquecida pelas tradições locais" (RICA, 48). Dentre as funções e ministérios são os catequistas os principais responsáveis pela formação e crescimento da fé, enquanto que o presbítero coordena e acompanha de perto todo o itinerário catecumenal. Trata-se de um ministério fundamental para o progresso daqueles que fazem o caminho da fé (cf. RICA, 48). Por compartilharem a mesma forma de vida, "os catequistas leigos têm uma sensibilidade especial para encarnar o evangelho na vida concreta deles. Acabam se tornando uma referência para o seu futuro de fiéis" (DGC, 230).

\section{5}

\section{A estrutura do itinerário catecumenal}

Apresentadas três das principais características do catecumenato, apresentaremos a estrutura do processo catecumenal, os diversos tempos e etapas a serem percorridos para atingir a maturidade cristã. $O$ assunto já foi de certa forma apresentado, quando refletimos a dinâmica da progressividade. 
Conheceremos agora melhor cada um dos momentos irrenunciáveis da caminhada da iniciação catecumenal e suas características específicas.

A estrutura catecumenal torna-se mais clara se lermos novamente o seu pedido de restauração: 'Restaura-se o Catecumenato com adultos, dividido em diversas etapas. O tempo do Catecumenato, estabelecido para conveniente instrução, será santificado com os sagrados ritos a serem celebrados em tempos sucessivos" (SC, 62)! Verifica-se que no próprio pedido de restauração feito pelo Concílio manifesta-se em linhas gerais a organização catecumenal. Os sagrados ritos a serem celebrados em tempos sucessivos diz respeito a sua estruturação, dividido em quatro tempos, marcadas com três grandes celebrações (etapas). Précatecumenato, catecumenato, purificação/iluminação e mistagogia constituem os 4 períodos a serem percorridos pelo catecúmeno rumo à maturidade cristã, celebrada sacramentalmente nos sacramentos da iniciação à vida cristã. Rito de admissão ao catecumenato, celebração da eleição ou inscrição do nome e celebração dos sacramentos da iniciação são, por sua vez, as três etapas celebradas liturgicamente que fazem a passagem de um tempo ao outro.

\subsection{1}

\section{Pré-catecumenato: um tempo de descoberta}

O pré-catecumenato, dedicado ao primeiro anúncio, é o primeiro grau do itinerário da iniciação à vida cristã, o qual em nenhuma hipótese deve ser omitido (RICA, 9). Dentre os objetivos centrais desta etapa estão o despertar da fé (DAp, 278a; 289; 299; DNC, 43), o desejo de aderir e seguir a Cristo e à Igreja. "É o tempo da evangelização em que, com firmeza e confiança, se anuncia o Deus vivo e Jesus Cristo" (RICA, 9). Neste período, valorizam-se as motivações e disposições do 'simpatizante, ${ }^{302}$. "Da evangelização realizada com o auxílio de Deus brotam a fé e a conversão inicial, pelas quais a pessoa se sente chamada do pecado para o mistério de amor de Deus" (RICA, 10). Em outras palavras, nesta etapa "o catecúmeno se defronta com o problema da conversão e quer tornar-se cristão" (RICA, 6). Transparecem fortemente neste período a dimensão eclesial (RICA, 15), a experiência de Igreja, marcado pelo relacionamento profundo entre os candidatos, introdutor, família e grupos cristãos (RICA, 11 e 68).

\footnotetext{
${ }^{302}$ Os fiéis nesta fase da iniciação são chamados ‘simpatizantes' ou 'candidatos'.
} 
Trata-se de um primeiro contato com os fundamentos da vida cristã (RICA, 15), os quais serão gradualmente amadurecidos ao longo da caminhada. O que se pretende com o pré-catecumenato é auxiliar o candidato na abertura inicial à fé. Por ser o tempo da primeira evangelização (RICA, 7) o objetivo maior é ajudar o iniciante no seu primeiro sim, no intuito de fazer a passagem dos germes da fé ao desejo de seguir mais intensamente o Deus de Jesus Cristo. O prefixo pré (pré-catecumenato) nos dá uma clara idéia de que o que acontece aqui e prérequisito fundamental para o que segue ${ }^{303}$. Se é verdadeiro o dito segundo o qual a primeira impressão é a que fica, então o pré-catecumenato define o tom para o todo do processo catecumenal. Para não poucos o tempo do pré-catecumenato é o primeiro contato com a comunidade cristã. Conclui-se que sua importância não pode ser desconsiderada, por vários aspectos, a destacar primeiramente o anúncio (kerigma), a acolhida, a conversão e experiência comunitária.

\section{5.1 .1}

\section{Pré-catecumenato e o anúncio kerigmático}

Pré-catecumenato e kerigma estão intrinsecamente interligados, pois a primeira etapa da iniciação é por excelência o tempo para o primeiro anúncio e da 'primeira evangelização'. Kerigma é o conteúdo central do pré-catecumenato. "Se anuncia aberta e resolutamente o Deus vivo e Jesus Cristo" (RICA, 9). Proposta, portanto, mais do que atual, quando já não se pode dar por pressuposto o primeiro anúncio, antes garantido pelo contexto cultural. Nesta perspectiva, o précatecumenato se distingue das demais etapas por seu caráter genuinamente kerigmático e cristológico. O diferencial da metodologia catecumenal está em não desconsiderar a necessidade do primeiro anúncio (Kerigma), o que era prescindível em tempos de cristandade. É fato que não há autêntico catecumenato sem verdadeira evangelização, do mesmo modo que não há evangelização eficaz

${ }^{303}$ Cf. KENP, R. A journey in faith: an experience of the catechumenate. Chicago: Sadlier, 1979 (Christian Initiation, 3), p. 32. No número 15, o RICA propõe as condições para entrar no segundo período catecumenal, o que significa que essas condições já tenham sido trabalhadas na etapa précatecumenal: "para esse primeiro passo, requer-se que os candidatos já possuam os rudimentos da vida espiritual e os fundamentos da doutrina cristã, a saber: a fé inicial adquirida no tempo do 'précatecumenato, o princípio de conversão e o desejo de mudar de vida e entrar em relação pessoal com Deus em Cristo; já tenham, portanto, certa idéia da conversão, o costume de rezar e invocar a Deus, e alguma experiência da comunidade e do espírito dos cristãos". 
sem um catecumenato que a acompanhe ${ }^{304}$. Aos já batizados, a primeira evangelização, o anuncio kerigmático assumem a características de reaproximação, reencantamento, redescoberta de Jesus Cristo e da comunidade eclesial. Com razão afirma Boróbio

A evangelização é uma evangelização de ponto de partida, que toca e mobiliza a pessoa inteira, no processo de busca, por aquilo que dá sentido a vida ... Sem esse kerigma evangelizador no qual se começa a crer, não se pode construir o edifício cristão ${ }^{305}$.

Pressuposto basilar do anúncio kerigmático é a experiência de fé do próprio evangelizador, caso contrário, "corremos o risco de anunciarmos rios de palavras e discursos, mas não o kerigma que provoca a profunda experiência da fé cristã" ${ }^{\prime 306}$. Enfim, percebe-se que no pré-catecumenato inicia-se com uma fé distante e confusa e termina com o ingresso no catecumenato, numa adesão global a Cristo e á Igreja. "Começa com uma conversão sob forma de tomada de consciência interior e acaba com uma aceitação plena dos valores evangélicos"307. Conclui bem Evangelii Nuntiandi: "tocados pela graça descobrem pouco a pouco a figura de Cristo e sentem a necessidade de entregar-se a ele" (EN 44).

\subsubsection{2}

\section{Pré-catecumenato e acolhida}

Dentre os muitos aspectos a serem destacados na etapa kerigmática précatecumenal assume um lugar central a acolhida, cuja urgência na Igreja é mais do que evidente. Do acolhimento inicial dependerá muito a continuação ou não do fiel no seu processo de iniciação. Com razão afirma Floristán que "quando um adulto quer aproximar-se de uma comunidade, o primeiro ministério da comunidade é o acolhimento" 308 .

O que se entende por acolhida no processo catecumenal? Como ela é efetivamente realizada neste período da iniciação cristã? O Ritual supera a tentação eclesial de situar a acolhida em momentos pontuais da vida pastoral da Igreja. No pré-catecumenato constata-se uma mudança da compreensão da

\footnotetext{
${ }^{304}$ Cf. FLORISTÁN, C. Catecumenato: história e pastoral da iniciação, op. cit., p 173.

${ }^{305}$ BOROBIO, D. Catecumenado para la evangelización, op. cit., p. 52.

${ }^{306}$ VELASCO, J. M. A. La transmisión de la fe en la sociedad contemporânea, op. cit., p. 19.

${ }^{307}$ FLORISTÁN, C. Catecumenato: história e pastoral da iniciação, op. cit., p. 180.

${ }^{308}$ FLORISTÁN, C. Catecumenato: história e pastoral da iniciação, op. cit., p. 177.
} 
acolhida entendia como mera recepção, sobretudo quando o candidato se aproxima da comunidade pela primeira vez, para transformar-se numa atitude permanente ao longo do processo iniciático. Dito diferente, para além da acolhida inicial e imediata do candidato que se simpatiza pela vida cristã ou quer retornar à vida eclesial, a dinâmica permanente da acolhida dá a tônica a toda esta primeira etapa, com destaque aos encontros informais, que são laboratório de partilha, escuta, discernimento, testemunho, hospitalidade, corresponsabilidade. No esforço de promover relações calorosas e fraternas, os encontros durante esta etapa buscam renunciar a qualquer tom de formalidade. Primordialmente, quer ser tempo de abertura, de conhecimento mútuo, das predisposições e motivações mais profundas do candidato, de suas experiências religiosas, interesses, a pergunta pelo sentido da vida. A partir de tal substrato o introdutor o ajudará numa reflexão mais profunda, de tal forma que ele possa perceber a diferença entre o que ele busca e o que ele vai receber no catecumenato ${ }^{309}$. O fio condutor do précatecumenato, vale ressaltar, é o primeiro anúncio de Jesus Cristo feito a partir do contexto existencial do candidato, e não o repasse de doutrina-conteúdo, que será garantido posteriormente, e assimilado numa perspectiva mais existencial. Neste sentido, os encontros no pré-catecumenato querem ser uma experiência teológicoantropológica, no sentido adotado por Rahner. Falar de Theos tem algo sobre o falar do antropos ${ }^{310}$. É tempo para 'contar história' (story telling) ${ }^{311}$. Pouco se tem discutido nos meios eclesiais sobre a necessidade antropológica de compartilhar a própria jornada espiritual, na busca de significado ou ressignificação da própria existência à luz da existência de Deus. Por vezes, reina a 'conspiração de silêncio', que desencoraja as pessoas a falarem de sua jornada religiosa porque ninguém na Igreja pergunta sobre ela. Preocupada em falar, já que essa é sua tarefa central como proclamadora de uma Boa Nova, a Igreja tende a esquecer de ouvir. Não se pode desconsiderar a insatisfação que ronda as pessoas pelo fato que a maior parte do tempo receberem e ouvirem, sem espaço e lugar para falarem (story telling $)^{312}$. Urge um tempo para falar das próprias alegrais e tristezas, das

\footnotetext{
${ }^{309}$ Cf. Ibid., p. 179.

${ }^{310}$ DUNNING, J. The stages of initiation: Inquiry. In: Becoming a catholic Christian, op. cit., $p$. 180.

${ }^{311}$ Cf. Ibid., pp. 177-197.

${ }^{312}$ Ibid., p. 180.
} 
mortes e ressurreição, sem aquele 'imperialismo eclesiástico' que sugere que conversão é religiosa apenas quando parece religiosa ${ }^{313}$. Quando houver espaço para compartilha das próprias experiências, a Igreja será experimentada como 'nós' e não como 'eles', como uma comunidade de pessoas com histórias para partilhar e não como uma coisa ${ }^{314}$. O que significa ter história? É ser pessoa, e ser pessoa é ter uma história para contar. Sem minha história, não tenho identidade, não sei quem sou, para onde vou, e se vou para algum lugar como saberei se chegarei lá ${ }^{315}$. O trabalho pastoral ajudará a pessoa a articular sua própria história com o mistério da presença de Deus em sua vida.

As interrogações são momentos integrantes do processo da iniciação: quem sou eu, o que se busco, qual a concepção que se tem do cristianismo, da Igreja, da vida. Deseja fazer experiência do que? Paulatinamente serão a partir clareadas suas motivações e desejos, bem como lhe serão apresentados o que se oferece no processo catecumenal, suas exigências, aonde conduzirá o catecumenato $^{316}$. Trata-se de um tempo na qual serão esclarecidas as questões e interrogações que apareceram no primeiro contato, ou seja, estabelece-se um diálogo com as inquietações pessoais e mais profundas do candidato. Requer-se sensibilidade e interesse pela pessoa e sua história. Supõe escuta, diálogo, valorização da própria história, liberdade, busca de conhecimento da biografia do candidato, suas disposições e interesses, ainda que se apresente sob formas deturpadas e confusas ${ }^{317}$.

Levar a sério a historicidade do candidato é tarefa insubstituível da evangelização pré-catecumenal. Condição necessária e primeira para o começo do catecumenato consiste em respeitar seu contexto cultural, social e familiar; ou em outros termos, respeitar as razões de sua busca ou inquietude ${ }^{318}$. Na intuição de Alberich

Acolher quer dizer antes de tudo reconhecer o caminho já percorrido pela pessoa, captar seus problemas de fundo, as questões últimas que podem se esconder atrás

\footnotetext{
${ }^{313}$ Ibid., p. 181.

${ }^{314}$ Ibid., p. 183.

${ }^{315}$ DOWNS, T. A journey to self through dialogue: an excursion of spiritual self-discovery for individuals and groups, citado por DUNNING, J. The stages of initiation, op. cit., p. 182

${ }^{316}$ BOROBIO, D. Catecumenado para la evangelización, op. cit., p. 42.

${ }^{317}$ Ibid, p. 40.

${ }^{318} \mathrm{Cf}$. BOURGEOIS. Catéchèse catéchuménale. Parcours pour adultes et jeunes, citado por BOROBIO, D. Catecumenado para la evangelización, op. cit., p 41.
} 
de perguntas aparentemente banais. Assim, por exemplo, atrás de expressões como: 'gostaria de conhecer um pouco melhor o cristianismo' ou 'meu filho vai fazer a primeira comunhão, mas eu não fui batizado e nem sequer fui a Igreja', afloram as vezes, intenções e momentos decisivos de vida ${ }^{319}$.

Conclui-se o pré-catecumenato com "com o engresso no grau do catecumenato" (RICA, 7), através do rito de admissão ao catecumenato, onde novamente a acolhida eclesial é o diferencial, conforme o próprio nome sugere (Rito de admissão ao catecumenato) ${ }^{320}$. Neste momento, a acolhida é ritualmente celebrada, com gestos profundos que apontam para a graça de Deus (cf. RICA, 319).

Mesmo antes de terem celebrado os sacramentos da iniciação já são oficialmente membros da Igreja. "Desde então os catecúmenos, cercados pelo amor e a proteção da Mãe Igreja como pertencendo aos seus e unidos a ela, já fazem parte da família de Cristo: são alimentados pela Igreja com a Palavra de Deus e incentivados por atos litúrgicos ..." ${ }^{321}$. Significativa são as palavras de admissão: "entrem na Igreja, para participar conosco na mesa da Palavra de Deus"” (RICA, 90). Ao candidato, através do diálogo interrogatório, é pedido uma primeira adesão. Supõe-se um novo relacionamento com Deus e com a Igreja a partir desse novo passo dado. O Rito de acolhida dever ser celebrado preferencialmente com a presença de toda a comunidade (RICA, 70).

Ainda dentro da perspectiva da acolhida catecumenal, o Ritual da Iniciação busca contemplar em sua proposta pedagógica o acompanhamento personalizado. São vários os momentos nos quais transparecem a atenção direcionada a cada indivíduo na sua particularidade. $\mathrm{Na}$ etapa do précatecumenato é o ministério do introdutor que vem ao encontro de tal necessidade. "O candidato que solicita sua admissão entre os catecúmenos é acompanhado por um introdutor, homem ou mulher, que o conhece, ajuda e é testemunha de seus costumes, fé e desejo" (RICA, 42$)^{322}$.

\footnotetext{
319 ALBERICH, E. BINZ, A. Formas e modelos de catequese com adultos, op. cit., p. 34.

${ }^{320}$ Cf. os números 6, 14-18, 42, 50, 65.2-5, 66.2, 68-69, 370-372. Dentre os principais momentos do Rito de admissão estão: a exortação, diálogo, primeira adesão, exorcismo, renúncia aos cultos não-cristãos, assinalação na fronte e sentidos, ingresso na Igreja, entrega do Evangelho, preces.

${ }^{321}$ Cf. RICA 18, que faz referência a LG, 14 e AG, 14.

${ }^{322}$ Ao final da etapa catecumenal ( $2^{\mathrm{a}}$ etapa) os introdutores podem ser substituídos pela madrinha ou padrinho, embora o Ritual diz que preferencialmente a madrinha ou padrinho seja o próprio introdutor. Cf RICA, 42.
} 
A atenção personalizada está igualmente contemplada na processualidade da iniciação, isto é, a estrutura do catecumenato leva em consideração a liberdade ao ritmo de cada pessoa, sem um tempo pré-determinado. Assim, "essa estrutura vem determinada pela mesma historicidade do homem, pela progressividade no crescimento da fé, pelo caráter processual que exige espaço e tempo"323.

Transparece aqui a dimensão mistagógica da evangelização. O mistagogo, inspirado na mistagogia divina, é aquele que conduz ao mistério, por meio de um processo de acompanhamento que acolhe o neófito na sua particularidade e alteridade, entrando em diálogo com ele, para a partir daí aprofundar uma experiência de fé, de confiança, de entrega, de respeito ao processo pessoal ${ }^{324}$.

Enfim, "o que importa desde o princípio é a manifestação do rosto maternal da Igreja expresso na acolhida da comunidade dos fiéis" ${ }^{225}$.

\section{5 .2}

\section{Catecumenato: a segunda etapa do processo da iniciação ${ }^{326}$}

Concluído o pré-catecumenato e tendo sido acolhido ao grau de catecúmeno com o rito de admissão, inicia-se o período mais longo e central do processo catecumenal, caracterizado por uma formação mais intensa, através da qual mergulha-se mais profundamente no mistério do Deus de Jesus Cristo. A catequese ocupa um lugar central na fase catecumenal. Trata-se de sua principal atividade $^{327}$.

Todos os tempos do processo catecumenal visam a maturidade cristã, mas é de modo especial o tempo do catecumenato, segundo grau do itinerário, que está mais diretamente responsável por oferecer as bases sólidas da construção de um novo perfil de crente, que preze pela formação, pela pertença eclesial, pela participação responsável. Enquanto que a primeira etapa concentra-se no primeiro anúncio, na acolhida eclesial, no 'contar história', o período posterior, catecumenato, é um tempo prolongado de maturação na fé, com ênfase na

\footnotetext{
${ }^{323}$ BOROBIO, Catecumenado para la evangelización, op. cit., p. 19.

${ }^{324}$ COSTA, R. F. Mistagogia hoje, op. cit., p. 115.

${ }^{325}$ BORÓBIO, D. A celebração na Igreja, op. cit., p. 28.

326 Vale lembrar que a nomeclatura do segundo período denominado 'catecumenato' coincide com a nomeclatura de todo o processo catecumenal. Importa não confundir as terminologias.
} 
catequese e na participação litúrgica, com sua decorrente vivência do compromisso apostólico. Dito diferente, é o tempo oportuno para que a féconversão cresça e amadureça (Cf. RICA, 19, 97, 105).

Dos quatro tempos do catecumenato é este o mais prolongado de todos, cuja finalidade é levar à maturidade aquelas disposições espirituais manifestadas no período anterior. Seu objetivo maior é proporcionar ao catecúmeno uma maturidade global, capaz de formar sua personalidade, suas opções e escolhas. Nas próprias palavras do RICA, “o catecumenato é um espaço de tempo em que os candidatos recebem formação e exercitam-se praticamente na vida cristã. Desse modo, adquirem madureza as disposições que manifestaram pelo ingresso" (RICA, 19). O Ritual de iniciação entende a etapa do catecumenato como o período de instrução pastoral e "formação para a vida cristã integral”, introdução "nos mistérios da salvação", "na prática dos costumes evangélicos", iniciação "nos sagrados ritos, celebrados em épocas sucessivas", introdução "na vida da fé, da liturgia e da caridade do povo de Deus" (RICA, 98).

Transparece aqui o trabalho de conjunto da pedagogia catecumenal. O précatecumenato, por ser o tempo oportuno para a descoberta da fé e de diálogo com aquelas disposições básicas, torna-se de suma importância para que o conteúdo catequético, agora na segunda etapa, não seja recebida tão somente como conhecimento teórico, mas capaz de refletir a própria história do catecúmeno ${ }^{328}$. A partir dos conteúdos da catequese, o catecúmeno é incentivado e auxiliado a estabelecer um diálogo entre a História da Tradição cristã (catequese) e sua história pessoal 'contada', ('history telling') na etapa anterior. Quando isto acontece, a catequese torna-se plena de sentido, e não meramente conteúdos a serem assimilados, uma vez que seu objetivo não é o mero saber, mas entrar em conhecimento íntimo com o mistério (cf. RICA, 19.1).

Importa perceber que é a partir desta etapa que dá-se início a uma maior integração fé-vida, catequese-liturgia. Posto isto, aprofundaremos o lugar da liturgia na iniciação cristã catecumenal. Embora a integração catequese liturgia não seja exclusiva deste segundo período, é aqui onde ela é intensificada.

\subsubsection{1}

${ }^{328}$ Cf. IVORY, T. The Stages of Iniciation. II. The Catechumenate. In: Becoming a Catholic Christian, op. cit., p. 203. 


\section{Catequese e liturgia, um casamento necessário na iniciação à vida cristã}

Um dos maiores desafios pastorais no processo de transmissão da fé consiste em romper a distância existente entre a formação catequética e participação litúrgica. O abismo em voga insiste em manter, de um lado a catequese, na sua tarefa de doutrina-ensino e, de outro, a liturgia, como ato de culto, por vezes revestido de caráter de obrigação religiosa. Catequese e liturgia constituem então, via de regra, mundos autônomos, sem unidade de fundo. A catequese, preocupada com os aspectos pedagógicos e transmissão de conteúdo, e a liturgia, por sua vez, focada na realidade celebrativa encontram na prática fraco elo $^{329}$. Se catequese significa fazer ressoar a mensagem, então mais do que natural que ela seja também um lócus de experiência, lugar para tornar-se 'ouvinte da Palavra', portanto, marcada pela densidade litúrgica, espiritual e celebrativa, além da característica de ensino que lhe é própria.

Os documentos do magistério eclesial insistem na articulação entre liturgia e catequese, afirmando inclusive de forma muito feliz que a liturgia é fonte mesma da catequese. ${ }^{330}$.

O Diretório Nacional Catequético assim se expressa: "Os autênticos itinerários catequéticos são aqueles que incluem em seu processo o momento celebrativo como componente essencial da experiência religiosa cristã" (DNC 118). Continua o Diretório: "É tarefa fundamental da catequese iniciar eficazmente os catecúmenos e catequizandos nos sinais litúrgicos e através deles introduzi-los no mistério pascal" (DNC 120).

Investir em uma iniciação cristã litúrgico-sacramental que relacione anúncio, formação, celebração e vivência da fé é um caminho necessário para

329 Cf. LIMA, L. A. A unidade da catequese e liturgia na iniciação cristã. In: Revista de catequese. São Paulo: Unisal, ano 29, n. 114, abril/junho, 2006, p. 34.

330"Não só pela riqueza de seu conteúdo bíblico, mas pela sua natureza de síntese e cume de toda a vida cristã, a liturgia é fonte inesgotável de catequese. Nela se encontram a ação santificadora de Deus e a expressão orante da fé da comunidade. As celebrações litúrgicas, com a riqueza de suas palavras e ações, mensagens e sinais, podem ser consideradas uma 'catequese em ato'. Mas, por sua vez, para serem bem compreendidas e participadas, as celebrações litúrgicas ou sacramentais exigem uma catequese de preparação ou iniciação" (CR 89). Cf. também Christus Dominus, n. 14. CONCÍLIO VATICANO II. Decreto Christus Dominus sobre o munus pastoral dos bispos na igreja. Petrópolis: Vozes, 1966; Gravissimum Educationis, n. 4. CONCÍLIO VATICANO II. Declaração Gravissimum Educationis sobre a educação cristã. Petrópolis: Vozes, 1966; CT, $n$. 23; DNC, n. 118; O DGC, no número 95 fala de fonte e fontes da catequese. A Palavra de Deus é a grande fonte da catequese, mas há também outras fontes, ou seja, lugares concretos de onde a catequese extrai sua mensagem. A liturgia é uma das fontes. 
superar uma compreensão catequética concebida unicamente como doutrina, e a liturgia como apêndice à educação da fé. Não seria a distância entre catequeseliturgia a principal vilã da não continuação da vida comunitária eclesial após a recepção dos sacramentos ${ }^{331}$ ? Concluída a iniciação cristã, o que seria então ponto de partida para o início de uma vida sacramental, torna-se ponto final e conclusivo. Não estaria entre os motivos de tal realidade o fato de não se ter iniciado devidamente na vida litúrgica durante o percurso catequético?

A liturgia comporta forte densidade catequética, pois "celebra e expressa o mistério de Cristo como mistério de salvação que se realiza hoje na Igreja, numa ação sacramental expressiva e eficaz"332. Portanto, "como lugar de proclamação da Palavra e como lugar de comemoração ritual, a liturgia é fonte de

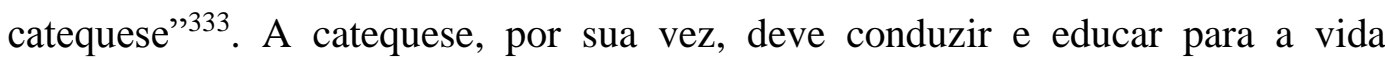
litúrgica. Se aceitamos a afirmação central da Sacrosanctum Concilium segundo a qual a liturgia é cume e fonte da vida cristã (SC, 10), então uma catequese que não inicia na vida litúrgica perde sua razão de ser, além de transformar os sacramentos em mero ritualismo individualista, no horizonte do 'salva tua alma'. O último documento do episcopado brasileiro sobre Iniciação à Vida Cristã expressa claramente tal idéia.

A catequese deve levar ao sacramento. Não tem sentido fazer de outro jeito. Mas só um bom processo de iniciação pode dar ao sacramento o lugar que lhe cabe, que não faça dele um ponto de chegada sem prosseguimento de caminho ${ }^{334}$.

O que não se pode é ignorar a pergunta se a liturgia é iniciática e se a iniciação cristã é litúrgica. Catequese e liturgia, "duas faces do mesmo mistério", se auxiliam mutuamente na missão de conduzir ao mistério ${ }^{335}$. A catequese sempre conservará sua dimensão de ensino e de instrução, caso contrário, perderia sua especificidade. Sabiamente ela tem aproveitado abundantemente e deve continuar a aproveitar de todos os recursos disponíveis da didática de origem

\footnotetext{
${ }^{331}$ Muitos manuais catequéticos são excelentes do ponto de vista dos roteiros e conteúdos, mas pecam em relação à educação litúrgica, isto é, é difícil perceber uma correspondência entre ensino e ritos celebrativos.

${ }^{332}$ CONSELHO EPISCOPAL LATINO-AMERICANO. A catequese na América Latina. Linhas gerais de orientação. Departamento de catequese (DECAT). São Paulo: Paulinas, 1986, n. 40.

${ }^{333}$ LUTZ, G. Liturgia, ontem e hoje, op. cit., p. 82.

${ }^{334}$ CONFERÊNCIA NACIONAL DOS BISPOS DO BRASIL. Iniciação à vida cristã: um processo de inspiração catecumenal, op. cit., n. 57.

${ }^{335}$ Cf. PAIVA, V. Catequese e liturgia, duas faces do mesmo mistério. São Paulo: Paulus, 2008.
} 
escolar. Contudo, tais práticas didáticas são insuficientes, pois não basta transmitir conhecimentos e tornar o cristianismo compreensível: urge torná-lo desejável e por isso é necessário passar pelo ver, pelo tocar, pelo sentir ${ }^{336}$.

\subsubsection{2}

\section{A integração catequese-liturgia no Ritual de Iniciação Cristã de Adultos}

Após sucintamente termos reafirmado a central e sólida conexão catequese-liturgia na iniciação à vida cristã, o que sempre constituiu um patrimônio da Igreja nascente, entrando em declínio após a Paz contantina, quando vigorou o 'catecumenato social', pretendemos sondar tal relação na caminhada catecumenal, ou seja, de que forma o retorno do catecumenato busca resgatar a conexão 'liturgia catequizante' e 'catequese celebrativa'.

A metodologia catecumenal entende a iniciação à vida cristã como uma intensa celebração, intercalada por momentos celebrativos e rituais, cujo ápice está na recepção dos sacramentos da iniciação à vida cristã, na Vigília pascal, celebrados unitariamente. A liturgia tem, portanto, um potencial catequético, e essa, por sua vez, não é mera atividade intelectual, mas caminho que conduz o catecúmeno à gramática litúrgica, nos seus ritos e símbolos. Ambos, catequese e liturgia se auxiliam na missão de introduzir o catecúmeno ao mistério pascal.

Em enúmeras passagens o RICA expressa a integração catequese-liturgia no processo catecumenal: "a catequese deve incentivar a participação nos mistérios litúrgicos" (RICA, 99); a liturgia alimenta, incentiva, introduz "no mistério da salvação e na prática dos costumes evangélicos" (RICA, 98). Os catecúmenos "são alimentados pela Igreja com a Palavra de Deus e incentivados por atos litúrgicos" (RICA, 18); são inseridos "gradativamente no culto de toda a comunidade" (RICA, 106). É tempo para "incentivar a participação nos mistérios litúrgicos, animar para o apostolado" (RICA, 99).

No número 19.1 o RICA reafirma o objetivo principal da catequese. "A catequese (...) distribuída por etapas e integralmente transmitida, relacionada com o ano litúrgico e apoiada nas celebrações da Palavra, leva os catecúmenos não só

\footnotetext{
336 FOSSION, A. Reconstruindo a catequese em tempos de crise: rumo a comunidades catequizadas e catequizadoras. In: Revista de catequese. São Paulo: Unisal, ano 29, n. 115, julho/setembro, 2006, p. 22.
} 
ao conhecimento dos dogmas e preceitos, como á íntima percepção do mistério da salvação de que desejam participar" (RICA, 19.1) ${ }^{337}$. A citação explicita o desejo em oferecer uma iniciação litúrgico-sacramental como lócus da experiência do Mistério. Portanto, dois aspectos de sua relevância que merecem ser destacados: iniciar na vida litúrgica, ao mesmo tempo proporcionar uma liturgia que efetivamente inicia no mistério.

A expressão iniciação litúrgica, aparentemente pacífica e natural, não tem estado tão visivelmente presente na agenda das atividades pastorais ${ }^{338}$. O RICA, por sua vez, parece não subestimar a necessidade de uma iniciação à vida litúrgica, aos símbolos e sinais da fé, via de regra extraídos das experiências humanas. Dito diferente, para o Ritual de iniciação é premente uma iniciação à vida litúrgica, a fim de que as celebrações sejam participação consciente, responsável e expressão de uma adesão maior a Cristo e à comunidade dos fiéis. Através das Celebrações da Palavra se quer introduzir "pouco a pouco na liturgia de toda a comunidade", "levá-los a saborear as formas e as vias de oração", e "gravar nos corações dos catecúmenos o ensinamento recebido quanto aos mistérios de Cristo ... “(RICA, 106) ${ }^{339}$.

Os catecúmenos são gradualmente introduzidos na vida de fé da comunidade cristã, isto é, na gramática litúrgica, não apenas conceitualmente mas celebrando-os. Conhece-se experimentando, e experimenta-se conhecendo. “Ajudados em sua caminhada pela Mãe Igreja, através dos ritos litúrgicos apropriados, já são por eles gradativamente purificados e protegidos pela bênção divina” (RICA, 19.3). Os 'degraus' a serem percorridos pelos catecúmenos, na dinâmica da progressividade, são celebrados liturgicamente com os ritos de passagem, além do que no decorrer das etapas outros momentos rituais são previstos, tais como orações, bênçãos, assinalação, unção, imposição das mãos,

\footnotetext{
337 No mesmo número, o RICA aponta outros meios para atingir a maturidade cristã. "Familiarizados com a prática da vida cristã ... acostumam-se a orar mais facilmente, dar testemunho da fé.." (RICA, 19.2) "Ajudados em sua caminhada pela Mãe Igreja, através dos ritos litúrgicos apropriados, já são por eles gradativamente purificados e protegidos pela benção divina. Promovem-se para eles celebrações da Palavra e lhes é proporcionado o acesso à liturgia da Palavra junto com os fiéis... (RICA, 19.3)

${ }^{338}$ São vários os documentos que abordam a dimensão educativa na vida litúrgica. Cf. DGC n. 85; 108; EN, n 43; Puebla, nn. 926-931; 941, 989, 1005; CT, n. 23; CNBB. Com adultos catequese adulta, op. cit., n. 170.

${ }^{339}$ O DGC assim se expressa: "iniciação não só na doutrina, mas também na vida e no culto da igreja, bem como na sua missão no mundo" DGC, n. 63.
} 
celebração da Palavra, entre outros sinais que asseguram assim a unidade educação-celebração da fé. Importa perceber a existência de uma introdução à vida da 'liturgia catecumenal' presente no processo de iniciação cristã ${ }^{340}$, ou seja, a liturgia marca o antes, o durante e depois da grande celebração sacramental. A conclusão a que chegamos é a de que a celebração litúrgica da iniciação à vida cristã se desloca do momento único e exclusivo da recepção dos sacramentos da iniciação, ainda que esse seja o ápice, para uma catequese permanentemente celebrativa e iniciática.

Pode-se afirmar sem hesitação que a iniciação cristã catecumenal somente chega ao seu objetivo graças a sua dimensão litúrgica celebrativa, em consonância com a formação humana, espiritual, bíblica. Em síntese, há no catecumenato um empenho em introduzir o catecúmeno na vida de oração pessoal e comunitária ${ }^{341}$. Na mesma perspectiva, nos é permitido concluir que a Palavra de Deus ocupa no catecumenato um lugar central, seja nos encontros catequéticos seja no celebrar a fé. A Bíblia é o livro do catecúmeno. Não se faz catequese, sobretudo para adultos, a partir de manuais, mas com a Palavra de Deus. Vale lembrar que nossa realidade brasileira tem dado passos importantes no uso e centralidade da Palavra de Deus na catequese em particular, e na vida de fé em geral ${ }^{342}$.

\subsubsection{3}

\section{Centralidade do ano litúrgico e a variedade de símbolos e ritos no processo catecumenal}

Mas como efetivamente aparece a integração catequese-liturgia no catecumenato? Duas são as expressões mais visíveis: na centralidade do ano litúrgico e na variedade de ritos celebrativos.

\footnotetext{
${ }^{340}$ Cf. FLORISTÃN, C. Catecumenato, op. cit., p. 288.

${ }^{341}$ Muito oportuno é o comentário de Francisco Catão e Ernani Reis ao abordar o primado da oração na iniciação cristã. "A oração tem o primado no Credo, do momento em que a fé é compreendida como sendo 'antes de tudo adesão pessoa a Deus e somente depois, inseparavelmente, acolhimento da verdade revelada'. Tem igualmente o primado sobre os sacramentos que são, por natureza atos litúrgicos, isto é, sinais eloqüentes de uma realidade que, evidentemente os ultrapassa: a comunhão espiritual com Deus, de conhecimento e amor ... Tem ainda o primado sobre os mandamentos que não são senão o ensinamento que nos auxilia a viver a vida no Espírito. CATÃO, F.; REIS, E. M. Oração e catequese com adultos. In: Revista de catequese. São Paulo: Paulus, ano 27, n. 108, dezembro/outubro, 2004, p. 41.

${ }^{342}$ A partir da Dei Verbum cresceu a conscientização da leitura orante da Bíblia, além da valiosa contribuição de Carlos Mesters, com seu método de leitura popular da Bíblia. Cf. CONCÍLIO VATICANO II. Constituição Dogmática Dei Verbum sobre a Revelação Divina. Documento do Vaticano II, 1965, Petrópolis: Vozes, 1966.
} 
No processo catecumenal o ano litúrgico recebe a centralidade em duplo momento: nos conteúdos, isto é, a narração da História da Salvação, baseada no tempo litúrgico, e nas celebrações litúrgicas catecumenais realizadas em sintonia com o ano litúrgico, cujo destaque está no tempo pascal. O DNC confirma a intenção do RICA: “A vigília Pascal, centro da liturgia cristã, e a espiritualidade batismal são inspiração para qualquer processo catequético" (49 c).

O ritmo do catecumenato está diretamente direcionado ao ano litúrgico, para o qual convergem todas as atividades. "Cuidem de que a catequese seja penetrada do espírito evangélico, em harmonia com os ritos e o calendário litúrgicos, adaptada aos catecúmenos e, na medida do possível, enriquecida pelas tradições locais" (RICA, 48). Em outra passagem do mesmo livro se confirma a mesma dinâmica: "A catequese ... distribuída por etapas e integralmente transmitida, relacionada com o ano litúrgico e apoiada nas celebrações da Palavra (RICA, 19. 1). Conclui-se que o catecumenato é um itinerário pascal, centrado no calendário litúrgico, onde se é possível experimentar a espiritualidade de cada tempo litúrgico.

O segundo momento ilustrativo a ser destacado na simbiose catequeseliturgia no catecumenato está na riqueza dos ritos celebrativos e símbolos litúrgicos. Os ritos já foram por nós abordados em vários momentos do presente capítulo. Revisitaremos agora pelo viés da integração catequese-litúrgica.

É por demais refletida a eficácia da linguagem simbólica na experiência humana e religiosa. O símbolo é uma linguagem expressiva e fundamental na vida humana, capaz de expressar as experiências mais profundas e significativas ${ }^{343}$. Por comunicarem mais do que a linguagem discursiva, as realidades humanas mais profundas são expressas por símbolos e ritos, acompanhadas na sua maioria por celebrações e festas. É o caso, por exemplo, da forte densidade celebrativa na passagem do aniversário, onde o bolo, a vela, o ambiente são mais do que meros endornos. Todo fato significativo é devidamente celebrado, pois "aquilo que não é celebrado não pode ser aprendido em sua profundidade e em seu significado para a vida" $" 344$.

\footnotetext{
${ }^{343}$ ALBERICH, A. Catequese evangelizadora, op. cit. p. 319.

${ }^{344}$ Ibid., p. 321.
} 
Atento a essa realidade, o catecumenato não abre mão da dimensão simbólica da fé, em primeiro lugar por expressar a ação de Deus e a respectiva resposta humana, posteriormente por tratar-se de fonte pedagógica inesgotável ${ }^{345}$. Cabe aqui ressaltar não tratar-se de instrumentalização do significado teológico dos ritos em vista de fins pedagógicos. O catecúmeno é auxiliado em sua caminhada por ritos sagrados, que além da força pedagógica, são sobretudo canais da graça de Deus, isto é, transmitem a graça transformadora de que são portadores. Deve vigorar o cuidado para não cair em mero ritualismo. "Se o catecumenato não pode converter-se em magia ritualista, tão pouco pode chegar a ser racionalismo desumanizante" 346 .

Rito de admissão: A partir da segunda etapa do processo catecumenal, inicia-se com a intensidade catequética uma maior intensidade celebrativa e ritual da fé cristã. A primeira e significativa celebração catecumenal realiza-se na admissão ao catecumenato com a celebração de acolhida, já abordado no item anterior, com forte intensidade acolhedora. Dentre os gestos rituais desta celebração, destaca-se a assinalação da cruz na fronte do candidato admitido ao catecumenato $^{347}$.

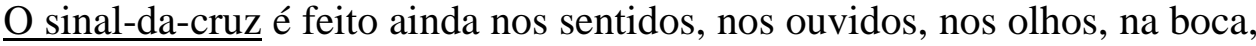
no peito, nos ombros, para que "ouçam a voz do Senhor", "vejam a glória de Deus", "respondam à palavra de Deus", "Cristo habite pela fé em seus corações" e "carreguem o jugo suave de Cristo" (RICA, 85).

O rito de admissão termina com a entrada na Igreja, expressando assim a acolhida dos catecúmenos na mesa da Palavra de Deus. A partir desse momento eles passarão a ser alimentados pelo Senhor na liturgia da Palavra, junto com a comunidade. Quem preside convida os catecúmenos a entrar com os introdutores

\footnotetext{
345 “A liturgia pode se tornar, para a catequese, um manancial inesgotável de elementos simbólicos ou de motivos concretos para iniciar os indivíduos nos aspectos do mistério de Cristo e da Igreja e para promover a fé e a vida cristã". SARTORE, D. Catechesi e liturgia. In: SARTORE, D; TTRIACCA, A. M (Eds). Nuevo dizionario de liturgia. Cinisello Balsamo. Paoline, 1988, p. 228 ${ }^{346}$ BOROBIO, D. La iniciation, op. cit., p. 548.

${ }^{347}$ São dirigidas as seguintes palavras: $\mathrm{N}$ e N, Cristo chamou a vocês para serem seus amigos; lembrem-se sempre dele e sejam fiéis em segui-lo! Para isso, vou marcar vocês com o sinal da cruz de Cristo, que é o sinal dos cristãos. Este sinal vai daqui em diante fazer que vocês se lembrem de Cristo e de seu amor por vocês". Segue o sinal da cruz: "Recebe na fronte o sinal-dacruz: o próprio Cristo te protege com o sinal de seu amor. Aprenda a conhecê-lo e segui-lo". (RICA, 83).
} 
na Igreja: (N. e N.) entrem na igreja, para participar conosco na mesa da Palavra de Deus" (RICA, 90).

Acolhidos oficialmente no seio da Igreja, dá-se início aos encontros catecumenais catequéticos, concentrados na segunda etapa, os quais são acompanhados das Celebrações da Palavra, cuja finalidade, de acordo com o RICA, é "gravar nos corações dos catecúmenos o ensinamento recebido quanto aos mistérios de Cristo e a maneira de viver que dai decorre...; 'levá-los a saborear as formas e as vias da oração'; 'introduzi-los pouco a pouco na liturgia de toda a comunidade' (RICA, 106). São, portanto, celebrações próprias do catecumenato, podendo ser realizadas após a catequese (RICA, 108), que visam fazer a experiência do mistério e iniciar o catecúmeno gradativamente na liturgia eucarística da comunidade dos fiéis. Afirma Cassiano Floristán: "São necessárias para captar a história da salvação num sentido sacramental. Celebram as maravilhas que Deus fez, faz e fará". Vale lembrar que "evidentemente, devem ser celebrações da palavra e não lições de catecismo, isto é, trata-se de celebrar e não de explicar; de experimentar e não de conhecer. O que se pretende é conseguir a participação dos catecúmenos na liturgia"348.

Bênçãos: Nas benções, que são dadas ao fim das Celebrações da Palavra, o catecúmeno recebe ânimo e força para a continuidade de sua caminhada espiritual. São preces de acompanhamento do catecúmeno (RICA, 102; 119; 124; 374), e “expressam o amor de Deus e a solicitude da Igreja, afim de que, não possuindo ainda a graça dos sacramentos, recebam da Igreja coragem, alegria e paz para continuarem o trabalho e a caminhada" (RICA, 102) ${ }^{349}$.

Eleição: Encerra-se a etapa catecumenal com o rito da eleição aos sacramentos da Iniciação Cristã. Celebrado no primeiro domingo da Quaresma, o rito recebe o nome de “eleição' porque a Igreja admite o catecúmeno baseada na eleição de Deus, em cujo nome age. Chama-se também 'inscrição dos nomes' porque os candidatos, em penhor de sua fidelidade, inscrevem seus nomes no registro dos eleitos” (RICA, 22). São “eleitos para serem iniciados nos sagrados

\footnotetext{
${ }^{348}$ FLORISTÁN, C. Catecumenato, op. cit., p. 189.

${ }^{349}$ Uma das bênçãos assim reza: "Senhor Deus todo-poderoso, olhai os vossos servos e servas que são formados segundo o Evangelho de Cristo: fazei que vos conheçam e amem e, generosos e prontos, cumpram a vossa vontade. Dignai-vos prepará-los por esta santa iniciação e incorporai-os à vossa Igreja para que participem dos vossos mistérios neste mundo e na eternidade" (RICA, 123).
} 
mistérios" (RICA, 147). "Deus é sempre fiel ao seu chamado, e nunca lhes negará a sua ajuda. Vocês devem se esforçar para serem fiéis a ele e realizar plenamente o significado desta eleição" (RICA, 147).

Escrutínios: Nessa etapa da caminhada, denominada purificação, são previstos os escrutíneos, tradicionalmente realizados no terceiro, quarto e quinto domingos da quaresma, cujo objetivo é conduzir o eleito a um maior conhecimento de si mesmo, discernimento de seu estado de conversão, ao mesmo tempo que transmitem a força de Deus para continuar na progressiva preparação rumo a maturidade cristã. Os Escrutínios pretendem "purificar os espíritos e os corações, fortalecer contra as tentações, orientar os propósitos e estimular as vontades, para que os catecúmenos se unam mais estreitamente a Cristo e reavivem seu desejo de amar a Deus" (RICA, 154) ${ }^{350}$.

O Rito de unção, (RICA, 26.2; 54; 65.6; 127-132; 206-207; 212; 218), com óleos dos catecúmenos entre a renúncia e a profissão da fé, igualmente muito significativo, quer exprimir "a necessidade da força divina para que o batizado, libertando-se dos laços da vida passada e vencendo a oposição diabólica, faça convicto a profissão de fé e a mantenha firmemente toda a sua vida" (RICA, $212)^{351}$.

Entregas: Ainda na etapa da Eleição são previstas as Entregas dos Símbolos da fé, o Creio e a Oração (Pai Nosso). Sem sombra de dúvida, trata-se de um dos ritos mais significativos do itinerário catecumenal. A Igreja transmite, ('Entregas') aos eleitos a fé que professa. "Uma vez completada a preparação doutrinal dos catecúmenos, ou, pelo menos, começada no tempo oportuno, a Igreja repassa com amor os documentos que desde a antiguidade constituem o compêndio de sua fé e de sua oração" (RICA, 181).

São esses alguns ritos celebrativos e elementos simbólicos que, ao acompanhar a formação catequética, antecedem o grande rito da celebração dos sacramentos da iniciação cristã. São teológico e pastoralmente fontes inesgotáveis de espiritualidade que ajudam o catecúmeno a adentrar no que a iniciação se

\footnotetext{
${ }^{350}$ Cf. VELA, J. A. Reiniciación Cristiana, respuesta a um bautismo 'sociológico', op. cit., 143. 351 A oração de consagração do óleo assim reza: “Ó Deus, força e proteção de vosso povo, que fizestes do óleo um sinal de fortaleza (...) concedei o dom da força aos catecúmenos que com ele forem ungidos". RICA, 131. E a fórmula da unção: "O Cristo Salvador vos dê a sua força simbolizada por este óleo da salvação".
} 
propõe, isto é, mergulho no mistério. Celebrar as etapas percorridas, invocar as bênçãos de Deus durante o percurso, responder ao chamado de Deus pela mediação simbólica e ritual, solicitude e cuidado maternal na Igreja são alguns dos significados mais profundos da variedade ritual da metodologia catecumenal.

A teologia sacramental valoriza a importância dos ritos na capacidade de moldar a personalidade de quem está sendo iniciado. A maturidade é resultante do encontro da ação salvífica celebrada com a correspondente adesão à graça oferecida. Cada rito exprime essa dupla dimensão, manifestando assim de uma só vez a primazia da graça divina e a resposta do ser humano a essa graça ${ }^{352}$.

\section{6}

\section{O tempo da purificação/ iluminação}

O tempo da iluminação, realizado no período da quaresma, é o mais curto das quatro etapas. “A última preparação dos 'eleitos' coincide com o tempo quaresmal, cujo currículo lhes será proveitoso tanto por sua estrutura litúrgica como pela participação da comunidade" (RICA, 139). Ele quer ser para o eleito um intenso período de retiro na caminhada da iniciação à vida cristã, possibilitando-lhe uma profunda revisão de vida, exame da consciência e espírito de penitência ${ }^{353}$. O enfoque neste período é colocado não na catequese e sim na vida interior (cf. RICA, 25). Desejo do RICA é que o eleito progrida no conhecimento de si mesmo e, através de sincero exame de consciência e penitência, seja instruído gradativamente sobre tal mistério e possa libertar-se das conseqüências do pecado e das influencias diabólicas ${ }^{354}$.

Inicia-se esse tempo com a 'eleição' do catecúmeno aos sacramentos da iniciação cristã, cuja celebração ritual é uns dos momentos centrais no processo catecumenal $^{355}$, ou melhor, é o "ponto capital de todo o catecumenato" (RICA, 22), pelo significado teológico e pastoral que a ritualidade lhe confere. Os não

\footnotetext{
${ }^{352}$ LELO, A. F. A iniciação cristã, respuesta a um bautismo 'sociológico', op. cit., p. 68.

${ }^{353}$ No Brasil, merece destaque as Campanhas da Fraternidade, realizadas todos os anos no tempo quaresmal, por meio das quais a Igreja além dos gestos concretos é chamada à conversão a partir da temática proposta pela Campanha de cada ano. Portanto, de grande utilidade para os catecúmenos no tocante à espiritualidade de conversão e penitência. ORMONDE lembra que a oração do Ofício Divino são momentos importantes para a iluminação dos eleitos. Cf. ORMONDE. D. O tempo da purificação e iluminação. In: Revista de Liturgia, setembro-outubro, 2003.

${ }^{354}$ Cf. LELO, A. F. A iniciação cristã, op. cit., p 71.

${ }^{355}$ Se possível, o Rito da Eleição deve ser celebrada pelo bispo ou seu representante (RICA, 138).
} 
batizados declaram o desejo de se tornarem cristãos, enquanto que os já batizados, de completar a iniciação sacramental, e diante de tal desejo, são "eleitos para serem iniciados nos sagrados mistérios" (RICA, 147), isto é, nos sacramentos da iniciação à vida cristã.

Denomina-se 'eleição' porque a Igreja admite o catecúmeno baseada na eleição de Deus, em cujo nome age. Chama-se também 'inscrição dos nomes' porque os candidatos, em penhor de sua fidelidade, inscrevem seus nomes no registro dos eleitos (RICA, 22).

Um passo a mais é dado pelos catecúmenos no itinerário da vida cristã, agora na categoria de eleitos. Um ministro, em nome da comunidade, pede oficialmente que os catecúmenos sejam recebidos aos sacramentos da iniciação (Cf. RICA, 22 e 235). Importância fundamental na eleição recebe o parecer da comunidade, dos padrinhos e dos responsáveis pela caminhada dos catecúmenos, que declaram a idoneidade dos candidatos (cf. RICA, 41). Pode ser ouvido também o grupo dos catecúmenos (cf. RICA, 137). Nesta perspectiva, "quem faz a eleição é a comunidade e coincide com a opção fundamental do candidato"356.

Conclui-se esse tempo com a celebração dos sacramentos da iniciação à vida cristã, celebrados conjuntamente "na santa noite da vigília Pascal” (RICA, $208)^{357}$, pois ela é “o tempo próprio para a iniciação nos sacramentos” (RICA 8). A mesma afirmação encontramos no Diretório Nacional de Catequese: "A vigília pascal, centro da liturgia cristã, e a espiritualidade batismal são inspiração para qualquer processo catequético" (DNC n 49 c).

Nota-se a importância que a quaresma assume no processo da iniciação cristã. Ela "renova a comunidade dos fiéis juntamente com os catecúmenos e os dispõe para a celebração do mistério pascal, ao qual os sacramentos de iniciação associam cada um" (RICA, 21).

\subsection{1}

\footnotetext{
${ }^{356}$ FLORISTÁN, C. Catecumenato: história e pastoral da iniciação, op. cit., p. 167. Já abordamos em outro momento a riqueza dos ritos e símbolos, sobretudo nesse período. Há de lembrar que no Brasil optou-se por colocar a entrega do Símbolo e da Oração do Senhor, próprios desse tempo, no tempo do catecumenato. Cf. RICA, 25 e 53.

${ }^{357}$ Caso os sacramentos não possam ser celebrados na vigília pascal, há as seguintes sugestões: em primeiro lugar o próprio domingo da ressurreição (RICA, 58) e os dias da semana na oitava da páscoa (RICA, 55), depois o tempo pascal (RICA, 58), por último, também o tempo comum, mas privilegiando, na medida do possível o dia de domingo (RICA, 59).
} 


\section{Unidade dos sacramentos da iniciação cristã e o caráter pascal do catecumenato}

O Ritual de Iniciação, em consonância com a renovação da teologia sacramental, resgata o significado dos sacramentos da iniciação como participação no mistério pascal, cujo conteúdo central é a morte e ressurreição de Jesus. Pelos sacramentos da iniciação, há uma participação sacramental e existencial nesse mistério salvífico. Nas palavras do próprio Ritual, "a iniciação cristã é a primeira participação sacramental na morte e ressurreição de Cristo" (RICA, 8). Resulta disto que "toda a iniciação deve ter carácter pascal" (RICA, 8). Nos sacramentos, celebrados na vigília pascal, ou mesmo se celebrado fora dela, é de fundamental importância que transpareça a alegria da ressurreição.

A partir do caráter pascal, torna-se compreensivo a unidade dos três sacramentos da iniciação, o que não é apenas uma questão litúrgica: batismo, crisma e eucaristia se fundamentam sobre a unidade do mistério pascal. São ritos significativos e operativos do mesmo mistério salvífico, orientados a realizar, de modo progressivo, a plena configuração com Cristo, na Igreja ${ }^{358}$.

Ao orientar que os três sacramentos sejam celebrados unitariamente na noite da Vigília Pascal torna-se evidente o desejo de recuperar a unidade teológica e litúrgica dos três sacramentos, perdida no percurso da história, quando começou a prática generalizada do batismo de crianças, conseqüentemente o isolamento dos sacramentos, entendidos como efeitos autônomos e isolados ${ }^{359}$. É a partir da oficialização da religião, entre cujas conseqüências está a generalização do batismo de crianças, que dá início ao rompimento da unidade sacramental, um desafio que prevalece ainda hoje. Se até o Vaticano II a tônica estava nos efeitos salvíficos produzidos por cada sacramento em si, isolados, sem conexão entre eles, o que está em jogo agora é o resgate do sentido unitário teológico e litúrgico dos sacramentos da iniciação, que desde os primórdios eram concebidos não como três momentos independentes mas uma única e plena participação no mistério pascal e configuração a Cristo.

${ }^{358}$ Cf. GOEDERT, V. M. Batismo e missão. In: SILVA, J. A.; SIVINSKI, M. (orgs). Liturgia. Um direito do povo. Petrópolis: Vozes, 2001, p. 103.

359 “As Observações preliminares gerais, n’ 1-2, apresentam uma teologia unitária e orgânica dos três sacramentos, válida para o batismo de adultos e de crianças; ressaltam o nexo entre eles, enquanto são constitutivos da iniciação cristã e acharem-se intimamente ligados entre si, porque somente estes, não isoladamente, mas em conjunto, conduzem os fiéis à sua plena estatura em Cristo". LELO, A. F. A iniciação cristã, op. cit., pp. 46-47. 
A recuperação da unidade dos sacramentos da iniciação, portanto, se deve a uma unidade teológica mais profunda, isto é, provém da realidade históricosalvífica da qual participam os 'eleitos' ${ }^{360}$. Recorda o Livro litúrgico do catecumenato que

Conforme antiquíssimo uso da liturgia romana, o adulto não é batizado sem receber a confirmação imediatamente depois do batismo, salvo se grave razão o impedir. Esta conexão exprime a unidade do mistério pascal, a relação entre a missão do Filho e a efusão do Espírito Santo e o nexo entre os sacramentos, pelos quais ambas as pessoas divinas vêm com o Pai àquele que é batizado (RICA, 34).

Digno de nota é a concepção da iniciação à vida cristã entendida como o grande sacramento, cuja celebração sacramental é o ápice de uma longa caminhada em direção ao mistério pascal. O equívoco está em olhar para os sacramentos como responsáveis isolados por todo o processo de iniciação ${ }^{361}$. A catequese deve conduzir ao sacramento. Não tem sentido de outra forma. Contudo, é através de bom processo de iniciação que dá ao sacramento o lugar que lhe cabe, que não faça dele um ponto de chegado sem prosseguimento da caminhada ${ }^{362}$. Se é verdade que tudo converge para a celebração dos sacramentos, também é verdade que eles não são fim em si mesmos, mas sinal, sacramentos de uma adesão maior a Jesus Cristo.

Mais uma vez é Lelo que aprofunda a questão:

A mútua referência dos três sacramentos é pouco matizada nos livros de catequese. É comum encontrarmos catequistas que não sabem relacionar o Batismo, a confirmação e a Eucaristia. É justamente esse dinamismo referencial que garante a unicidade de todo o processo, fundamenta a identidade do ser cristão e projeta-a como tarefa pascal a ser cumprida ao longo de toda e existência do fiel. Historicamente, assimilamos como único modelo válido de iniciação aquele por etapas, calcado numa visão que reforça o efeito do sacramento (ação ex opere operato) isolado dos demais e do processo eclesial ${ }^{363}$.

\section{6 .2}

\section{A prática do batismo de crianças diante da unidade sacramental}

\footnotetext{
${ }^{360}$ LELO, A. Catequese com estilo catecumenal, op. cit., p. 93.

${ }^{361}$ Cf. LELO, A. F. A iniciação cristã, op. cit., p. 217.

${ }^{362}$ CONFERÊNCIA NACIONAL DOS BISPOS DO BRASIL. Iniciação à vida cristã: um processo de inspiração catecumenal, op. cit., n. 57.

${ }^{363}$ LELO, A. Catequese com estilo catecumenal, op. cit., pp. 40-41.
} 
Apesar de não ser nossa intenção aprofundar a questão do batismo de criança, não podemos, sem mais, deixar passar à margem um assunto tão delicado, ainda mais quando afirma-se na pastoral, hoje, a prioridade aos adultos. Vozes a favor e contra se alternam. Na história do cristianismo o desaparecimento ou enfraquecimento paulatino do catecumenato coincide com a generalização do batismo de crianças. Difícil saber o que é conseqüência do que. Fato é que "a proporção de adultos e de crianças que se apresentam ao batismo, se inverte progressivamente com a cristianização da sociedade, e acaba-se admitindo na Igreja, salvo raras exceções, somente crianças pequenas" ${ }^{364}$. As controvérsias maiores da prática batismal infantil, tanto no ambiente das Igrejas protestantes como católica, surgiram nas décadas de 50 e $60 .{ }^{365}$ Afirmações contundentes contra a prática batismal infantil são encontradas em ambos os lados. No ambiente protestante, Urs von Balthasar afirma que o batismo de crianças é "de certo modo a mais grave de todas as decisões da história da Igreja" ${ }^{\text {366 }}$. Bonhoeffer critica igualmente a generalização maciça do batismo infantil, onde não existe uma comunidade de fé que possa alimentar a fé da criança. Ele reconhece a exaltação da graça no batismo, mas pais e padrinhos, comunidade não comprometida trata-

364 CABIÉ, R. La iniciación Cristiana. In: MARTIMORT, A. G. (ed). La Iglesia en oración. Introducción a la liturgia. Herder: Barcelona, $3^{\text {a }}$ ed. 1987, p. 626, citado por FLORISTÁN, C. Catecumenato, op. cit., p. 90. Sobre a história do batismo de crianças no cristianismo, cf. FLORISTÁN, C. Catecumenato, op. cit., pp. 90-107. Vale a pena conferir a tabela à p. 96 sobre a evolução histórica da iniciação cristã, no tocante a relação dos sacramentos. BOROBIO, D. Bautismo de niños y confirmación: problemas teológico-pastorales. Fundación Santa Maria: Madrid, 1987. Influência decisiva para a generalização do batismo de crianças teve o contexto de Santo Agostinho, diante da crise pelagiana. "O bispo de Hipona propôs as bases teológicas para justificar esta práxis, ao apresentar as idéias da fides aliena, ou fé emprestada da criança quando é batizada e a remissio peccatorum ou perdão dos pecados, entre os quais o mais relevante é o 'pecado original'”. FLORISTÁN, C. Catecumenato: história e pastoral da iniciação, op. cit., p. 93. Mais tarde, no século XII administrava-se o batismo nos primeiros dias após o nascimento, não somente no intuito de apagar o pecado original, como também pelos perigos de morte dos recémnascidos. Urge batizar, então, 'o quanto antes', quam primum baptizentur'. É desta época, portanto, que procedo a expressão quam primum baptizentur' do antigo CIC (c 770), devido a imortalidade infantil. A expressão foi canonizada no Concílio de Florença de 1442. Cf. GY, P. M. Quam primum. Note sur Le baptême des enfants, em LMD 32 (1952), 124- 128, citado por FLORISTÁN, C. Catecumenato, op. cit., p. 93. Vale a pena conferir a análise de Lelo no tocante à tradição do batismo no Brasil, fruto da cristandade. O batismo tornou-se sinal de reconhecimento público do ponto de vista social. Num contexto onde todos eram cristãos, ser batizado é ser reconhecido pela sociedade. Aos índios e negros ta certidão do batismo tinha efeito civil, acesso a sociedade e ser considerado 'gente', mesmo não sendo respeitado em sua dignidade. Cf. LELO, A. A iniciação cristã no Brasil. In: Revista de Catequese. São Paulo: Unisal, ano 27, n. 107, julho/setembro, 2004, pp. 5-18.

${ }^{365}$ Cf. FLORISTÁN, C. Controversias sobre el bautismo de niños. Fhase 10, 1970, pp. 39-70.

366 BALTHASAR, H. U. Ensayos teológicos. Vol II. Sponsa Verbi. Guadarrama, Madri, 1964, p. 25. 
se apenas de um 'costume burguês' ${ }^{367}$. O autor já apontava para a necessidade de iniciar uma nova práxis: a do batismo de adulto.

Na Igreja católica, se teologicamente o batismo de crianças é válido, as discussões começam no campo da pastoral, numa tensão entre uma pastoral de cristandade e uma pastoral missionária. Os argumentos a favor procedem da teologia agostiniana, na linha da 'remissão dos pecados' ${ }^{368}$. Outro argumento favorável aponta para a concepção do batismo como obra de Deus, convite à sua aliança, que faz da criança membro do seu povo. É sinal da graça e iniciativa divina. As crianças são batizadas na fé da Igreja, o que requer "o consentimento dos pais e a séria garantia de que a criança batizada receberá a educação católica" ${ }^{369}$. Entramos aqui num dos pontos mais críticos na atualidade. Que garantia se tem que a família se comprometerá com a iniciação cristã de seus filhos? Os argumentos contrários apontam as seguintes questões: a falta de um elemento central: a fé pessoal, o desejo de batizar-se, a conversão. A dificuldade hoje de uma posterior aceitação da fé por parte dos filhos, portanto, a liberdade de escolha.

Uma possível 'solução' pastoral parece não ser a contraposição entre batismo de crianças ou batismo de adultos. Decisivo é que se assegure uma iniciação cristã adequada após o batismo, apesar das conhecidas dificuldades para que isso aconteça, a começar pelo não comprometimento dos pais que pedem o batismo a seus filhos ${ }^{370}$. Não se nega a importância e o valor de tal práxis que perpassou quase toda a história do cristianismo. O que não se pode é exaltá-la como a única referência, como a história nos mostra ${ }^{371}$. Em vez de exaltá-lo é preciso 'relativizá-lo' diante de outros elementos da iniciação. O problema maior está no batismo de criança isolado, fora de um projeto integral de iniciação cristã $^{372}$. Para Boróbio não se trata de não levar a sério a pastoral do batismo de criança, ao contrário, precisa-se dar uma atenção especial a partir de um projeto

${ }^{367}$ Cf. BONHÖFFER, Zur Tauffrage. Ein Gutachten. In: Gesammelte Schriften. Munique, 1960, III, 431-454, citado por FLORISTÁN, C. Catecumenato, op. cit., p. 97.

${ }^{668}$ A Instrução sobre o batismo de crianças, de 1980, expõe tal argumentação, na qual cita testemunhos favoráveis dos Concílios de Catargo, Viena, Florença e Trento (n. 6-8). Cf. FLORISTÁN, C. Catecumenato: história e pastoral da iniciação, op. cit., p. 100.

${ }^{369}$ Instrução sobre o batismo de crianças, de 1980, n. 15.

${ }^{370}$ FLORISTÁN, C. Catecumenato: história e pastoral da iniciação, op. cit., pp. 102-103.

${ }^{371}$ Cf. BOROBIO, D. La iniciacion Cristiana, op. cit., p. 368. Cf. ainda BOROBIO, D. Proyecto de iniciatión Cristiana, op. cit., pp. 33-99.

${ }^{372}$ BOROBIO, D. La iniciacion Cristiana, op. cit., p. 368. 
integral na qual ele seja ponto de partida ${ }^{373}$. Concomitante a tal projeto, decisivo é que se invista cada vez mais no mundo dos adultos, na reiniciação daqueles que justamente foram batizados enquanto crianças e hoje apresentam uma fé fragmentada.

\section{7}

\section{Mistagogia: aprofundar a graça sacramental}

O processo catecumenal converge para a "primeira participação sacramental na morte e ressurreição de Cristo" (RICA, 8), o que não significa dizer que o itinerário da iniciação chegou ao término com a recepção dos sacramentos. Um antes, durante e um depois da celebração sacramental garantem a novidade da proposta catecumenal enquanto participação gradual no mistério de Cristo e da Igreja. Em outras palavras, o tempo da mistagogia, o último do processo e realizado no tempo pascal, garante a continuidade experiencial da iniciação após a iniciação ontológica sacramental.

Novamente é possível verificar a íntima relação entre iniciação à vida cristã e formação permanente. Para Castellano, “o cristão plenamente iniciado está chamado a converter-se no que já é" ${ }^{374}$. Em síntese, "para o cristão, num sentido amplo, começar o tempo da mistagogia, significa iniciar a experiência cotidiana, histórica, dinâmica, do quanto recebeu e seguirá recebendo, porém agora conjugada com a vida e a história" 375 .

Quase sempre o Ritual utiliza a palavra 'mistagogia' entre aspas elucidando que os tempos anteriores também são mitagógicos por introduzirem paulatinamente o fiel no mistério de Cristo. Contudo, a experiência mistagógica feita nesse quarto tempo conserva seu diferencial por ser o experimento dos

\footnotetext{
${ }^{373}$ BORÓBIO fornece várias sugestões em vista de um projeto integral da pastoral do batismo de criança. Destacamos: uma preparação que promova um 'processo catecumenal' para os pais. Umas poucas reuniões somente servem para suscitar algumas questões e minimamente a preparação da celebração. Preparar bem os leigos e colaboradores da pastoral, em vista da acolhida, encontros pessoais e comunitários, suscitar a experiência, a oração, promovendo a participação.Cf. BOROBIO, D. La iniciacion Cristiana, op. cit., pp. 368-369.

${ }^{374}$ CASTELLANO, La iniciación Cristiana y el camino espiritual". In: Phase. Barcelona, v. 61, n. 246, 2001, p. 463.

${ }^{375}$ Cf. LELO. Aplicação no Brasil do Ritual de Iniciação Cristã de Adultos, op. cit. In: Revista de catequese. São Paulo: Unisal, ano 27, n. 118, julho/setembro, 2004, op. cit., pp. 9-10.
} 
sacramentos recebidos ${ }^{376}$, uma vez que "a índole e a eficácia próprias desse tempo provém dessa experiência nova e pessoal dos sacramentos e da comunidade" (RICA, 40). Os neófitos, agora já iniciados, participam da comunidade e possuem os mesmos sacramentos como os demais membros da comunidade. $\mathrm{O}$ que lhe falta é esse tempo oportuno para degustar a realidade sacramental da qual agora são partícipes, pois "só no transcorrer do tempo, de fato, o cristão poderia experimentar o quanto é maravilhoso a nova condição decorrente do encontro pascal com Cristo" 377 .

Mistagogia é, portanto, tempo para maior conhecimento e vivência dos mistérios celebrados, da linguagem simbólica; é o tempo para aprofundamento e experimento da graça sacramental. Todos necessitam de um tempo para saborear o significado dos símbolos celebrados e experimentados há pouco ${ }^{378}$. Enfim, “o que caracteriza o tempo da mistatogia é a experiência"379.

Experiência esta que visa um "conhecimento mais completo e mais frutuoso" ${ }^{380}$, do mistério (RICA, 38), sempre realizada no seio da comunidade eclesial. Se os neófitos agora possuem como os demais cristãos a realidade sacramental, é somente com a prática da vida cristã que essa experiência vai crescendo, adquirindo "novo senso da fé, da Igreja e do mundo" (RICA, 38). Na etapa da mistagogia "obtem-se conhecimento mais completo e frutuoso dos 'mistérios' através das novas explanações e sobretudo da experiência dos sacramentos recebidos" (RICA, 38).

Trata-se de uma "experiência nova e pessoal dos sacramentos e da comunidade" (RICA, 40). Os neófitos, já iniciados sacramentalmente, dispõe de um tempo para o "aprofundamento das relações com a comunidade dos fiéis" (RICA, 7d)), que busca “cercá-los de afeição e ajudá-los a se sentirem felizes na comunidade cristã" (RICA, 41.5). É um tempo em que os recém-batizados, com o

\footnotetext{
${ }^{376}$ Cf. ORMONDE, D. Iniciação Cristã de Jovens e Adultos, op. cit. In: Revista de Liturgia. São Paulo: Unisal, março-abril, 2004, op. cit., p. 31.

${ }^{377}$ LELO, A. A iniciação cristã, op. cit., p 119.

${ }^{378}$ FLORISTÁN, C. Catecumenato: história e pastoral da iniciação, op. cit., p. 216.

${ }^{379}$ ORMONDE, D. Iniciação Cristã de Jovens e Adultos, op. cit. In: Revista de Liturgia. São Paulo: Unisal, março/abril, 2004, op. cit., p. 24.

${ }^{380} \mathrm{O}$ ritual ao mostrar o específico de cada etapa deixa claro que a experiência dos sacramentos é a característica maior da etapa da mistagogia. "Pré-catecumenato', caracterizado pela primeira evangelização; o do 'catecumenato', destinado à catequese completa; o da 'purificação e iluminação', destinado à mais intensa preparação espiritual; e o da 'mistagogia', assinalado pela nova experiência dos sacramentos e da comunidade" (RICA, 7).
} 
auxílio dos padrinhos e de toda a comunidade entram "em relações mais estreitas com os fiéis e adquirem, assim, novo impulso e nova visão das coisas" (RICA, $30)^{381}$. A comunidade deve se empenhar a fim de que a integração dos neófitos na comunidade seja "completa e feliz" (RICA, 235).

Embora o Ritual de Iniciação não fale claramente de catequese neste período, encontramos lá a expressão "novas explanações" (RICA, 38), o que nos dá a entender a realização de encontros catequéticos, as chamadas catequeses mistagógicas, próprias desse período, cuja função é explicar o sentido simbólico e sacramental do mistério recebido ${ }^{382}$. Assim entendiam já os Padres da Igreja. Segundo eles, primeiramente se comunica o mistério, depois se explica-o. "Se trata de viver primeiro os sacramentos e depois buscar seu significado" 383 . De acordo com a Conferência Episcopal da Espanha, os principais traços da catequese visam "ajudar a entrar na realidade do mistério que se celebra. Procede sempre do visível ao invisível', do signo ao significado, dos 'sacramentos' aos mistérios. Não deve partir de idéias ou conceitos, mas da experiência dos mesmos dons recebidos de Deus, para fazer os batizados descobrirem sua própria identidade e mostrar-lhes o itinerário que Deus está disposto a completar mediante os sinais sacramentais, conduzindo os batizados à ação de graças, a uma conversão mais profunda, a uma celebração gozosa das obras divinas, traduzidas depois em uma conduta coerente" 384 .

A liturgia será o modo ordinário de viver a graça do mistério pascal. Daí a importância e "lugar primordial" das missas dominicais (RICA, 40). Em cada celebração, a Palavra ilumina a iniciação realizada, enquanto a nova participação sacramental aprofunda e possibilita a experiência pessoal. Recorda Lelo que "a recepção dos sacramentos na vigília pascal é renovada durante o período pascal, quando amadurece um estilo autêntico de participação litúrgica"385. Chama a

381 Os padrinhos são de vital importância também nesse período. "É seu dever ensinar familiarmente ao catecúmeno como praticar o evangelho em sua vida particular e social, auxiliá-lo nas dúvidas e inquietações, dar-lhe testemunho cristão e velar pelo progresso de sua vida batismal" (RICA, 43).

${ }^{382}$ Sobre as catequeses mistagógicas, cf. SOBRERO, J. Catequesis mistagógicas: un modelo del siglo V para hoy. In: Phase 33, 1993; ONÃTIBIA, I. La Catequesis litúrgica de los Padres. In: Phase 20, 1980.

${ }^{383}$ VELAS, J. A. Reiniciación cristiana, op. cit., p. 149.

384 CONFERÊNCIA EPISCOPAL ESPAÑOLA. La iniciación Cristiana. Reflexiones y orientaciones. Madrid, 1998, n. 49 LXX Asamblea Plenaria.

${ }^{385}$ LELO, A. A iniciação cristã, op. cit., p 124. 
atenção a insistência que o RICA dá à presença da comunidade nessas celebrações. Os neófitos são "lembrados na homilia e, se for oportuno, na oração dos fiéis" (RICA, 236). "Por todo o tempo pascal, os neófitos ocupem, nas missas de domingo, lugar especial entre os fiéis e todos procurem participar da missa com seus padrinhos; sejam lembrados na homilia e, se oportuno, na oração dos fiéis"; que se conclua o tempo da mistagogia com uma celebração especial, próximo ao domingo de Pentecostes, "inclusive com festividades externas"; valorize-se o aniversário do Batismo do neófito, e que o bispo, na medida do possível, se reúna com os neófitos, celebre a Eucaristia com eles, "na qual poderão comungar sob as duas espécies” (cf. RICA, 235-239).

Enfim, mistagogia é o tempo do itinerário da iniciação em que os neófitos recebem ajuda especial, atenção e amizade da comunidade dos fiéis, padrinhos e pastores, e assim se sentem felizes e totalmente integrados na comunidade'.

Sinteticamente, este é o itinerário da iniciação catecumenal, com suas etapas e ritos, inspirado na metodologia dos Santos Padres do alvorecer da Igreja. A palavra 'etapa' aqui tem um significado um pouco diferente do que aparece na linguagem comum. As etapas são entendidas como 'portas' (algo que se abre, possibilitando avanço na caminhada), momentos fortes marcados por uma celebração específica que assinala a situação do iniciando dentro do processo, na passagem para o tempo seguinte" ${ }^{, 386}$. Os ritos de passagem, modeladores da personalidade do catecúmeno, representam um novo avanço na caminhada. Outros ritos realizados no decorrer dos tempos (bênçãos, exorcismos, escrutíneos ...) com forte carga simbólica apontam igualmente para os compromissos que estão sendo assumidos. A riqueza de tal estrutura é merecedora de um aprofundamento dos aspectos mais significativos e centrais de cada uma desses momentos.

Chegamos, assim, ao final do terceiro capítulo, no qual nos dedicamos a conhecer a dinâmica da iniciação cristã catecumenal. Resta ainda uma análise crítica da proposta catecumenal aqui apresentada.

\section{8}

\section{Análise crítica}

${ }^{386}$ CONFERÊNCIA NACIONAL DOS BISPOS DO BRASIL. Iniciação à vida cristãa: um processo de inspiração catecumenal, op. cit., $n$. 74 . 
$\mathrm{O}$ fio condutor desta primeira parte da pesquisa foi recordar constantemente a necessidade de um novo paradigma de iniciação à vida cristã, já em andamento desde o último Concílio ecumênico. Neste conjunto de aggiornamento da iniciação cristã interessou-nos de modo especial o catecumenato. É, sem dúvida, no catecumenato onde melhor e mais visivelmente ganha forma o novo perfil - modelo de transmissão da fé, em vista de uma fé adulta, consciente e responsavelmente assumida vivida.

A proposta é clara, e os elementos pastorais e eclesiológicos de sua pedagogia estão facilmente visualizados no RICA. Neste particular, a publicação do Ritual de Iniciação Cristã de adultos assume um significado impar. Sua existência é condição para que o catecumenato possa ser levado adiante.

Sinteticamente podemos apontar alguns elementos presentes no RICA no tocante à virada copernicânica do novo modo de transmitir a fé: de uma iniciação centrada no ensino para uma formação global e existencial; uma iniciação mais narrativa do que doutrinal; de uma catequese entendida como preparação aos sacramentos para 'educação na fé' querigmática, na qual Jesus Cristo é o centro; uma iniciação centrada na Palavra de Deus, onde a Sagrada Escritura assume o lugar central no processo da iniciação; uma iniciação mais celebrativa, na qual a catequese e liturgia se complementam; de uma comunicação apenas verbal para a pluralidade de linguagens e símbolos. Uma iniciação em que a pessoa é levada a sério, em sua historicidade, tempo e ritmo, sempre em perspectiva comunitária.

A riqueza catecumenal está igualmente em oferecer um caminho para reiniciação e reavivamento dos já batizados, porém afastados da vida eclesial ou com uma religiosidade mágico tradicional. Destaca-se, portanto, sobretudo para a realidade latino americana, o capítulo IV do Ritual, "Preparação para a confirmação e a eucaristia dos adultos, que batizados na infância, não receberam a devida catequese". Iniciação e reiniciação cristãs assumem aqui a mesma urgência, pois o que está em jogo é a necessidade de priorizar o mundo dos adultos, em vista de uma fé adulta, tanto dos já batizados na infância, como dos catecúmenos propriamente dito ${ }^{387}$.

\footnotetext{
387 Optamos por não acentuar por demais o específico de cada circunstância, ou seja, o catecumenato pré-batismal e pós-batismal, por entender que o mais importante são os elementos teológicos, litúrgico-pastorais comuns e irrenunciáveis a todas as situações. Urge, contudo a
} 
Portanto, trata-se de uma proposta pastoral mais do que atual. Ao mesmo tempo, não podemos deixar de ser realista e perceber que após quatro décadas de sua restauração, o catecumenato é, em não poucas realidades eclesias, desconhecido ou não assumido. Como entender tal fenômeno, se sua pertinência é inquestionável? Outro questionamento advém do fato de, mesmo onde ele é conhecido e aplicado, por vezes não 'funcionar'. Sejam padres e bispo que desconhecem, outros que não se entusiasmam com a proposta, seja a execução parcial da metodologia, o que compromete o projeto da iniciação cristã, seja a catequese de adultos confundida com catecumenato, pois 'quando tudo é catecumenato nada e catecumenato', fato é que os problemas são reais e estão aí, por vezes neutralizando uma maior efetividade da metodologia catecumenal. Neste particular, afirmamos então a limitação do catecumenato, não devido a sua proposta mas porque ele depende de vários fatores, e fundamentalmente reclama uma configuração eclesial condizente com a riqueza de sua proposta.

Importa desde já atentar para as consequências de uma iniciação cristã adulta. As exigências que traz consigo a catequese de adultos em geral e a restauração do catecumenato em particular apontam, dentre as muitas questões envolvidas, para estruturas eclesiais adultas, sem as quais qualquer esforço de implantação do novo paradigma de formação de fé cai por terra. Referimos particularmente à instituição paroquial, cuja estruturação tradicional não permite colocar em ato a novidade pastoral da iniciação catecumenal.

Importa ter presente que o catecumenato apresentado nesta primeira parte do trabalho, e já exaustivamente estudado por inúmeros especialistas, embora seja considerado 'um dos documentos de maior transcedência do Vaticano II' apresentando-se "como o modelo de toda catequese integral" 388 , não pretende salvar o problema da transmissão da fé nos dias atuais. Não se pode negar que entre o ideal e a prática existem passos a serem dados. Dificuldades estão presentes na implantação do catecumenato, e porque não dizer, limites na própria proposta catecumenal.

sensibilidade do agente evangelizador para fazer as devidas adaptações, a partir das orientações já oferecidas em cada capítulo destinado às diferentes circunstâncias.

${ }^{388}$ BORÓBIO, D. El Catecumenado y su situación el la Iglesia actual. In: Teología y Catequesis.San Dámaso: Madrid, 2002, n. 83, p. 81. 
No tocante aos limites do próprio RICA, Floristan aponta uma lacuna ao não levar em conta as diferenças culturais do iniciante. Trata-se da desafiante questão da inculturação da fé. De um lado, o Ritual tem a pretensão da universalidade, de outro lado, a fé nunca está desassociada da cultura. Como conciliá-lo, portanto, com as várias culturas, fazendo com que a proposta metodológica pastoral se torne significativa tanto aqui como acolá? Em várias passagens podemos observar o Ritual incentivar a liberdade para adaptações, contudo, permanece o desafio fazer acontecê-las ${ }^{389}$.

Permanece em aberto o desafio de adaptar os ritos às tradições das culturas locais, juntamente com a valorização dos elementos iniciáticos próprios de cada povo $^{390}$. A quem compete efetivamente as devidas adaptações? À paróquia, ao clero, aos catequistas, bispos? Certamente a todos, o que de certa forma tira todo o peso por vezes colocado sobre o próprio Rito de Iniciação. Apesar de Floristan ter razão em sua observação, defendemos a idéia que a Igreja local, as conferências, deveriam se empenhar com mais coragem no múnus da inculturação do RICA para que ele venha melhor desenhado com as cores da cultura local. Seria então um trabalho mais das Igrejas locais, Conferências episcopais, Regionais, Dioceses, do que função exclusiva do próprio Ritual de Iniciação Cristão de Adultos. No Brasil, o RICA foi publicado em 1974, e em 2001 recebe uma revisão e nova edição. Lelo afirma que essa nova edição não apresenta nenhuma adaptação a nossa realidade brasileira.

O RICA foi publicado no Brasil na Páscoa de 1974, e sua pedagogia sacramental não produziu as modificações na Pastoral, como se poderia supor. Mereceu revisão e nova edição em 2001. Porém essa nova edição não apresenta nenhuma adaptação do rito à índole brasileira ${ }^{391}$.

\footnotetext{
${ }^{389}$ Os números 64-67 falam das adaptações que o RICA reserva as conferências episcopais e ministros, portanto oferece possibilidades de mudanças e adaptações.

390 A Constituição sobre a Sagrada liturgia, no número 37, falando sobre adaptação litúrgica, recorda que "Não é desejo da Igreja impor, nem mesmo na Liturgia, a não ser quando está em causa a fé e o bem de toda a comunidade, uma forma única e rígida, mas respeitar e procurar desenvolver as qualidades e dotes de espírito das várias raças e povos. E continua no número 38: "Mantendo-se substancialmente a unidade do rito romano, dê-se possibilidade às legítimas diversidades e adaptações aos vários grupos étnicos, regiões e povos, sobretudo nas Missões, de se afirmarem, até na revisão dos livros litúrgicos; tenha-se isto oportunamente diante dos olhos ao estruturar os ritos e ao preparar as rubricas".

391 LELO, A. A iniciação Cristã, op. cit., p. 141. Dom Geraldo Lyrio Rocha, faz a seguinte observação: A nova edição apresenta os ritos "de uma forma mais didática e simples para facilitar o uso deste Ritual. Sem alterar a edição típica, optou-se por uma das alternativas de orações ou de monições, propostas, deixando as demais indicações nas rubricas ou no capítulo dos Textos diversos, para assim facilitar seu manuseio. A novidade aqui apresentada, (...) consiste
} 
Elementos tão caros à nossa tradição não podem ficar de fora do processo de iniciação cristã catecumenal, como por exemplo, leitura popular da bíblia, a piedade popular, o método ver-julgar e agir, a questão social, a devoção mariana, tão cara sabretudo ao povo brasileiro e latino-americado. Urge dos agentes de pastorais envolvidos com o catecumenato a perspicácia para transcrever o RICA para a realidade de cada cultura.

Outro cuidado que se há de ter diz respeito à correta compreensão e utilização da abundante riqueza dos ritos celebrativos, como expressão da permanente graça de Deus e correspondência humana rumo à maturidade religiosa, sem cair no mero ritualismo sem porquê. Se a catequese tradicional pecava por excesso de racionalização doutrinal, a utilização do Ritual não pode cair no erro oposto de transformar a beleza dos ritos em ritualismo.

Um aspecto crítico do RICA, a nosso ver, está na pouca ênfase à dimensão sociotranformadora, inerente à fé cristã. Não há como negar que a ligação fé-vida perpassa todo o itinerário catecumenal do Ritual, contudo, a ação sociopolítica, tão cara à tradição da Igreja latino-americana, é mais um dos aspectos da inculturação do RICA que precisa ser levado mais a sério na iniciação cristã, não como momentos durante o percurso da iniciação à vida cristã, e sim dimensão transversal de toda a formação cristã. No número 19 do RICA afirma-se que o catecumenato quer ser uma introdução "na vida da fé, da liturgia e da caridade do povo de Deus", iniciação "no mistério da salvação e na prática dos costumes evangélicos”. Percebe-se que se poderia enfatizar mais a solidariedade com os oprimidos e empobrecidos. Permanece, então, o desafio da releitura do Ritual a partir da realidade do Brasil, levando em conta a riqueza e o jeito próprio de viver a fé, a herança dos momentos eclesiais fortes do Continente (Medellin, Puebla, Santo Domingo, Aparecida). Dito diferente, jamais pode ser esquecido ou relativizado que o pobre é lócus teológico da iniciação à vida cristã.

basicamente em sua disposição gráfica. Foram introduzidas também as mudanças exigidas pelo novo Código de Direito Canônico e os textos bíblicos aprovados pela Sé Apostólica para uso litúrgico (...). RICA, 7. Percebe-se, portanto, tratar-se de mudanças periféricas. Para uma visão mais aprofundada da nova edição. Cf. LELO, A iniciação cristã, op. cit., pp. 140-144. 


\section{0}

\section{A INSTITUIÇÃO PAROQUIAL}

$\mathrm{Na}$ primeira parte da pesquisa nos concentramos na urgência pastoral da iniciação à vida cristã, com especial enfoque ao mundo dos adultos, a quem o Vaticano II recupera o catecumenato, cuja metodologia se apresenta como eficaz e renovado caminho de transmissão da fé no mundo atual, no qual a secularização cresce em ritmo acelerado.

Nesta segunda parte entraremos no questionado mundo paroquial, cuja afirmação de seu cansaço institucional não vem de hoje. As mudanças culturais em vigor colocaram a paróquia em estado de alerta, e hoje, no limiar do terceiro milênio, a crise para ter chegado ao seu limite. Certamente o leitor está se perguntando o porquê da temática da paróquia após três capítulos dedicados à iniciação à vida cristã. Apesar de já termos acenado anteriormente para a aproximação entre os dois temas, tal interrogação tem sua razão de ser, pois além da amplitude destes temas para uma tese doutoral, à primeira vista parece tratar-se de dois assuntos, iniciação cristã e paróquia, por demais distantes entre si, correndo o perigo de perder-se no vasto campo de reflexão que eles suscitam. Cientes do risco, acreditamos que, por tratar-se de uma tese eminentemente de cunho pastoral, tais temas, que constituem a nosso ver os dois maiores desafios pastorais da atualidade, devem ser abordados conjuntamente, dada a implicância mútua entre eles. Nesta perspectiva, o diálogo que iremos estabelecer entre as duas realidades quer chamar a atenção de que inócua se tornaria a tentativa de refletir sobre a iniciação cristã sem simultaneamente se perguntar pelas estruturas eclesiais adequadas para que esta mesma iniciação aconteça, ou ainda, para que o iniciado possa viver sua fé comunitariamente. Se o Concílio Vaticano II aposta no retorno do catecumenato como diferencial da iniciação cristã em tempos de descristianização, com a mesma urgência necessitamos de estruturas eclesiais que correspondam à riqueza da proposta catecumenal, caso contrário, o esforço pastoral resultaria em pôr vinho velho e odres novos.

Dentre os inúmeros modelos de comunidades eclesiais para dialogar com a iniciação cristã, nosso interesse está na bimilenar instituição paroquial, por haver entre elas uma enorme aproximação. Não se torna difícil afirmar a íntima relação 
entre iniciação cristã e estrutura eclesial paroquial. Vale recordar que sobre tal relação pouco se tem aprofundado. A tendência maior parece ser a abordagem isolada dos dois temas em questão, com pouca ou nenhuma reflexão sistemáticopastoral no que diz respeito ao movimento dialético entre eles.

Antes de colocarmos as duas instituições em diálogo, no próximo capítulo, queremos conhecer melhor a instituição paróquia, sua história, suas potencialidades e suas limitações. Assim como anteriormente nos debruçamos sobre a natureza, identidade e princípios pastorais da iniciação à vida cristã, com enfoque no catecumenato, cabe agora a mesma reflexão sobre a paróquia. Para questioná-la, criticá-la, propor mudanças faz-se necessário um conhecimento não superficial da mesma, caso contrário, tais questionamentos e proposições, evidentemente, também seriam superficiais.

\section{1}

\section{Origem e desenvolvimento da paróquia}

Conhecer a história da paróquia torna-se um imperativo se quisermos captar, através das nuanças e transformações históricas, sua identidade mais profunda. Engana-se, todavia, quem pensa ser tarefa fácil tal reconstrução, cuja história não é nem simples nem linear. A visita às metamorfoses históricas da paróquia não tem meramente interesse histórico, senão teológico e eclesial. Cada configuração paroquial ao longo do tempo, Igreja de Jerusalém, domus Eclesiae, paróquia rural, medieval, do Vaticano II etc, revela o esforço da Igreja para responder aos desafios de cada época, encontrando assim a melhor maneira de realizar sua missão, isto é, 'ser Igreja ao redor das casas', 'habitar junto a'. Dito com outras palavras, a Igreja em cada época buscou pensar o modelo paroquial em função de sua presença e inserção nos diferentes contextos culturais da sociedade. Neste sentido, 'paróquia' não existe. O que existem são paróquias ${ }^{392}$. Tal constatação permite-nos relativizar a configuração da paróquia e perguntarnos por seus elementos irrenunciáveis. Absoluta não é sua configuração estrutural e sim seus elementos teologais, seu compromisso evangelizador, sua vocação

\footnotetext{
${ }^{392}$ Cf. ROUTHIER, G. A paróquia: suas imagens, seus modelos e suas representações. In: BORRAS, A; ROUTHIER, G. A Nova Paróquia. Gráfica de Coimbra 2, p. 19.
} 
missionária e comunitária, às vezes sufocada, seja pelo contexto cultural, seja por sua estrutura, já não mais capaz de realizar sua missão.

Se a estrutura paroquial é histórica, por isso relativa em relação a outros aspectos teológicos e irrenunciáveis, oportuno se torna sondar o sentido sociológico de uma estrutura social. Por estrutura entende-se a organização interna de uma realidade, coisa, pessoa ou grupo. Pessoas, famílias, grupos tem uma estrutura $^{393}$. Estrutura aponta igualmente para o modo concreto de organização da vida e relacionamento entre pessoas e grupos. "Os tempos, os lugares de encontro, a modalidade como se desenvolvem os encontros, os sistemas de coordenação e de votação (...) constituem a estrutura de um encontro ou de um grupo",394. Verifica-se, portanto, que estrutura é condição necessária para a vivência de um valor, para exprimir seu espírito. "Os valores de diálogo, de participação, de comunhão, de pobreza, exigem uma estrutura correspondente" ${ }^{\text {395. Qualquer }}$ comunidade sem estrutura seria contradição ao seu próprio espírito ${ }^{396}$. Importa perceber a dinamicidade que envolve a realidade estrutural. Marcas típicas de sua realidade são a flexibilidade e funcionalidade, pois determinadas estruturas são válidas para um período mas não para outro ${ }^{397}$. Posto isto, o esforço de renovação da estrutura paroquial deve se perguntar, entre muitas outras questões vitais, pela capacidade de iniciação à vida cristã, isto é, quais as mudanças necessárias para que ela seja efetivamente casa da iniciação cristã.

Feitas essas observações, adentramos nos principais momentos da história paroquial, sem a pretensão de apresentar todas as nuanças ou pormenores, mas tão somente recordar os momentos mais relevantes de uma instituição eclesial significativa e importante, em busca de uma nova fisionomia.

\subsection{1}

\section{Antes do nascimento da paróquia: a Igreja das casas}

\footnotetext{
${ }^{393}$ Cf. CAPPELlarO, J. et alli. Comunione di comunitá. Progetto parrochia. 2 ed. Assis, 1990, pp. 48ss.

395 GIUSTINA, E. D. A paróquia renovada: participação do Conselho de Pastoral paroquial. Paulinas: São Paulo, 1986, p. 35.

${ }^{396}$ Cf. GREELEY, A. Sociologia e estrutura della Chiesa. In: Concilium: Revista Internacional de Teologia. Petrópolis, v. 06, fasc. 58, 1970, p. 38.

${ }^{397}$ Cf. CAPPELLARO, J. et alli. Comunione di comunitá, op. cit., p. 52.
} 
A origem da instituição paroquial remonta ao século IV, de acordo com os historiadores $^{398}$. Alguns acontecimentos históricos deste período foram determinantes para seu surgimento, dentre eles o edito de Milão, de Constantino em 313, o qual reconhece o cristianismo como religião lícita, dando aos cristãos o direito de se organizar e professar sua fé. Mais tarde, em 381, Teodósio oficializa o cristianismo como religião do Império.

Antes do nascimento da paróquia, a Igreja se organizava nas casas, igrejas domesticas (domus Ecclesiae), conforme nos atestam as fontes neotestamentárias. Pequenas comunidades cristãs se reuniam nas casas onde eram acolhidas por uma família que dispunha de um espaço suficiente para o encontro fraterno.

A primeira comunidade cristã surgiu em Jerusalém, fundada na proclamação da Palavra pelos apóstolos (At 2, 42-47; 4, 32-37), da pregação do Cristo ressuscitado, da convocação para a vivência na comunidade de fé, de caridade, oração, celebração e missão (At 6 , 4; 9,40;12,12; 8,15; 10,9). Os apóstolos eram ajudados por pregadores ambulantes, profetas, mestres ou catequistas $^{399}$.

As duas categorias tão acentuadas posteriormente, clero-povo, não existiam neste período. O que havia, sim, era a diversidade de ministérios e serviços, sobressaindo o ministério da comunidade ${ }^{400}$. No Novo Testamento todos são considerados povo sacerdotal, ou seja, inexiste a diferença entre sacerdotes e leigos $^{401}$.

\footnotetext{
${ }^{398}$ Cf. BORRAS, A.; ROUTHIER, G. A Nova Paróquia, op. cit.; BO, V. Parrocchia tra passato e futuro. Assis, 1977; URBINA, F. Historia y estructura e la parroquia. In: Pastoral missionera, ano 15, marzo-abril, 1981 (pp. 125-145).

${ }^{399}$ GIUSTINA, E. D. A paróquia renovada, op. cit., p. 39.

${ }^{400}$ Sobre a ministerialidade da Igreja primitiva, cf. LAURENTIN, R. Luz do Novo Testamento sobre a crise atual dos ministérios. In: Concilium, v. 08, fasc. 80, pp. 1242-1251; ALMEIDA, J. A. Leigos em quê? Uma abordagem histórica. São Paulo: Paulinas, 2006; CASTILLO, J. M. La comunidad y los ministérios. In: Pastoral Misionera, v. 5, ano 14, julio-agosto 1978 (pp. 35-45). ${ }^{401}$ ALMEIDA, J. A. Leigos em quê?, op. cit., pp. 19-20. Não aparece no Novo Testamento o termo leigo, derivado de laós, povo. "Apareceria, porém a realidade por ele indicada? É difícil para não dizer arriscado e anacrônico - identificar essa realidade. Um critério poderia ser o de tentar distinguir 'apóstolo' (nos vários sentidos que este termo recobre) e 'chefes de comunidade' (p. ex. prostaménoi, epískopos, presbýteros etc), de um lado, e os demais cristãos, de outro, que seriam considerados, então, leigos e leigas". ALMEIDA, J. A. Leigos em quê?, op. cit., pp. 21-22. A primeira vez que aparece o termo é na carta de Clemente Romano (95 d. C), quando descreve o culto levítico, sem, contudo, o mesmo sentido atual. Posteriormente, Tertuliano, Orígenes e Clemente de Alexandria irão empregar o termo leigo para designar aqueles cristãos que não pertencem ao clero. Outra transformação que a Igreja sofre a partir dos séculos III e IV é a gradativa oposição entre monges, considerados ligados às coisas espirituais, e os leigos, tidos
} 
São Paulo é, sem dúvida, o grande propagador do jeito de ser Igreja dos primórdios do cristianismo, a Igreja das casas, ao difundir o Evangelho de cidade em cidade, convocando os fiéis a se reunirem no primeiro dia da semana nas casas para bendizer o pão e o cálice, e partilhá-1o ${ }^{402}$. O apóstolo dos gentios conciliou ao mesmo tempo um projeto de Igreja universalista e doméstico ${ }^{403}$. Segundo Almeida, "Paulo faz da casa - estrutura básica da sociedade em que o cristianismo paulino nasceu e se desenvolveu - a estrutura-base das Igrejas por ele fundadas ... Paulo quer que a fé cristã seja vivida no seio da estrutura social básica dessas cidades, assumindo-a como base da comunidade cristã e imbuindo-a de um novo espírito, gerador de novas e até revolucionárias atitudes, sem, todavia, a desfazer, enquanto possível, em virtude da adesão à fé" ${ }^{404}$.

Nota-se que as Igrejas das casas não formavam um único modelo, nem tão pouco tinha uma administração central. Fundamental era a consciência de formarem uma única Igreja em cada cidade. O distintivo é a consciência da Igreja presente na cidade. Não existiam dioceses nem paróquias, nem demarcação territorial, por terem nascido nesse ou naquele bairro. Os crentes pertenciam à Igreja pelo falto de terem se convertido à fé e se integrarem livremente na comunidade $^{405}$. Fato é que se não é muito explícita a estrutura da Igreja no Novo Testamento, por não haver ainda uma definição do vocábulo jurídico ou sociológico, inquestionável é a íntima relação entre Igreja doméstica e cidade, no início do cristianismo, haja vista a terminologia das cartas paulinas, 'a Igreja que habita em...” Também São João prolonga a eclesiologia de Paulo, quando, por

ligados as coisas do mundo. Três grupos piramidais, serão consolidados: monges, clérigos e leigos. Cf. CABALLERO, B. Bases de una nueva evangelización. Madrid: Paulinas, 1993.

402 CASTELLUCCI, E. Essere comunità Cristiana oggi. In: Nuove forme di comunità Cristiana: Le relazioni pastorali tra clero religiosi, laici e território. Centro orientamento pastorale. $60^{\circ}$ Settimana nazionele di aggiornamento pastorale. Bolongna EDB, 2010, p. 69.

${ }^{403}$ Indo de cidade em cidade, Paulo implantava uma comunidade cristã a partir de um projeto universalista, isto é, ruptura com toda fechamento étnico, sem tabus sectários. "Enquanto o movimento de Jesus era fundamentalmente itinerante e desinstalado, a estratégia de Paulo promovia um cristianismo sedentário, baseado em comunidades locais, que dispunham de diversos ministérios próprios, de modo a não depender dos missionários de passagem; preocupa-se, de um lado, com o fortalecimento das comunidades recém-fundadas e, do outro, com a expansão da missão, abrindo novas frentes; não parava muito tempo numa comunidade, mantendo, porém, com todas, relações estreitas (através de visitas pessoais, do envio de delegados e/ou de cartas), confia na capacidade das Igrejas de subsitirem e de regularem sua vida com ampla liberdade". ALMEIDA, A. J. Paróquia, comunidades e pastoral urbana. São Paulo: Paulinas, 2009, p. 30.

${ }^{404}$ Cf. Ibid., p. 31.

${ }^{405}$ GIUSTINA, E. D. A paróquia renovada, op. cit., p. 39. 
exemplo, das setes cartas do Apocalipse (Ap 2-3) que são enviadas 'à Igreja de Éfeso', 'à Igreja de Coríntios', etc.

A relação de pertença com a Igreja local se dá em nível de cidade e não em circunscrições menores, como mais tarde será a divisão paroquial. Para o Novo Testamento, o que determina a Igreja local é a cidade. Segundo Comblin,

A ignorância da verdadeira natureza da Igreja local na teologia moderna é, por sua vez, um dos sinais e uma das causas da falta de relação entre o conceito de igreja e as categorias da historia temporal e, simultaneamente da falta de inserção da Igreja nas estruturas humanas ${ }^{406}$.

Destaca-se a heterogeneidade das Igrejas domésticas, nas quais participam pessoas de várias condições: escravos, livres, pobres, pessoas com ou sem recurso, de influência social ou não. Gregos, judeus, cristãos vindos do paganismo ou não, homens, mulheres, cidadãos, escravos, ricos ou pobres, se reconheciam na categoria teológica de irmãos. Foi lá que amadureceu a consciência de uma igualdade entre batizados ${ }^{407}$. As relações são próximas e calorosas, e a linguagem para indicar as relações comunitárias é a familiar; os ministros exercitam a paternidade, entre os batizados vigore a fraternidade, diáconos assumem a função dos servos da casa, as mulheres, a maternidade. Enfim, um clima familiar garantia a qualidade das relações na comunidade ${ }^{408}$. Não se põe em dúvida a experiência de acolhida e fraternidade, lugar de abertura a todos os batizados, independente do estrato social, fundamentada na leitura e no estudo da Palavra, na eucaristia, caridade e as exigências éticas daí decorrentes. As exortações familiares mostram as relações éticas nas relações no interior das casas, como é o caso da tradição apostólica de Hipólito que apresenta as condições para ser catecúmeno.

A família era o sujeito da evangelização; são famílias que acolhem outras famílias. Posteriormente, verifica-se uma perda da importância da família na missão. A família seria apenas uma espécie de propedêutica em relação à paróquia. Insistia-se no dever dos pais favorecer a formação cristã dos filhos, mas no entanto recebiam tal educação religiosa no centro paroquial ${ }^{409}$. Na experiência da 'domus Ecclesiae' a família hospedava outras famílias, o que é natural que a

${ }^{406}$ COMBLIN, J. Teologia da cidade. São Paulo: Paulinas, 1991, p. 191.

${ }^{407}$ CASTELLUCCI, E. Essere comunità Cristiana oggi, op. cit. In: Nuove forme di comunità cristiana, op. cit., p. 79.

408 Ibid., p. 77.

${ }^{409}$ Ibid. p. 78. 
vida comunitária girasse em torno dos ritmos familiares e as famílias, ao passo que o nascimento das paróquias, no século IV em diante, conduzira gradualmente a uma perda da importância da família na comunidade. Fato é que quanto mais as paróquias se tornam grandes, menos as famílias podem empenhar-se como sujeitos $^{410}$.

Portanto, são em pequenas comunidades (30-40 pessoas) reunidas em casas, estrutura social básica da sociedade, que a Igreja foi se firmando sócio e religiosamente nos primórdios do cristianismo. Era normal que a conversão do chefe da família, paterfamilias fosse acompanhada da conversão de todo o grupo familiar ${ }^{411}$.

Papel relevante tinham as mulheres nas Igrejas das casas ${ }^{412}$. Interessante o comentário de Estevez López

Em época paleocristã, a casa desempenhou a função central de lugar de reunião e estrutura de apoio, indispensável no trabalho missionário; isso favoreceu, sem dúvida, o acesso das mulheres às funções de liderança no interior das comunidades paulinas, pelo fato de que, em certo sentido, isso podia ser interpretado como uma extensão da sua atividade em âmbito doméstico ${ }^{413}$.

Tudo indica que quem acolhesse a Igreja em sua casa se tornava-se seu líder. É possível que a partir desses líderes naturais tenham surgido os epískopoi (cf. Fl, 1,1 $)^{414}$. Não era exceção a presença de pia batismal na domus Eclesiae ${ }^{415}$. Tal prática parece ter ido até o século IV quando nasceu o batistério nas basílicas cristãs. O batismo desde o início portava símbolos 'domésticos', na linguagem do novo nascimento (1 Pet 1, 3.23; Tt 3,5). Do mesmo modo que o nascimento físico

\footnotetext{
${ }^{410}$ Cf. CASTELLUCCI, E. Essere comunità Cristiana oggi, op. cit. In: Nuove forme di comunità crisiana, op. cit., p. 78.

411 “... Paulo procurava levar à conversão, o mais cedo possível, em cada localidade, um chefe de família, que colocasse à disposição uma casa adequada para os encontros da comunidade e que serviria igualmente como plataforma missionária" . ALMEIDA, J. A. Paróquia, comunidades e pastoral urbana, op. cit., p. 32.

${ }^{412}$ Cf. Ibid., p. 33, a relação das mulheres que aparecem no Novo Testamente, cujo protagonismo é notável. Destaque para Priscila e Áquila que aparecem em Corinto, Éfeso e Roma, onde são mencionados setes vezes no Novo Testamento.

${ }^{413}$ ESTEVEZ, L. Leadership femminile nelle comunità dell'Asia Minore. In: VALÉRIO, A. (ed). Donne e Bibbia: storia ed esegesi. Bologna: EDB, 2006, p. 251.

${ }^{414}$ Cf. HAINZ, J. Ekklesía; Strukturen paulinischer Gemeinde-Theologie und Gemeinde-Ordnung. Regensburg; Pustet, 1972, citado por ALMEIDA, Paróquia, comunidades e pastoral urbana, op. cit., p. 33.

${ }^{415}$ Como a encontrada em 1932, em uma das domus Ecclesiae da metade do século III, a Dura Europos, localidade do império romano no sul do Eufrates, atualmente na Síria Ocidental. Cf. CASTELLUCCI, E. Essere comunità Cristiana oggi, op. cit. In: Nuove forme di comunità cristiana, op. cit., p. 70.
} 
acontecia em família, estando presentes os familiares de sangue, era normal que no nascimento espiritual a inteira casa-família, presidida pelo pater famílias, o bispo, auxiliado pelos presbitérios irmãos e diáconos servos, se fizessem presentes $^{416}$.

'Havia uma clara consciência de comunhão entre essas Igrejas, conscientes de serem uma única Igreja ${ }^{417}$, evitando a tentação do exclusivismo ou fechamento em si mesmas, para não se degenerar em guetos.

O que teologicamente está em jogo, nas Igrejas domésticas, antes de tudo, não é a busca de uma possibilidade social para que se estabeleçam os vínculos de fraternidade e vida nova que exprimam a fé em Jesus Cristo" ${ }^{418}$. Calcula-se, com fundamento em testemunhos vários, sobretudo arqueológicos, que, em Roma, no século II, houvesse 25 Igrejas da casa, transformadas, mais tarde, em 'títulos' (em latim, títuli $)^{419}$.

\subsection{2}

\section{Títuli}

A partir do segundo século tais casas recebem o nome de tituli, ao gozarem de certa estabilidade para melhor estarem à disposição das comunidades cristãs. Tal nomeclatura se deve ao fato do nome do proprietário da casa estar gravado em uma pedra ou em uma tábua ${ }^{420}$. Mais tarde, entre os séculos V e VI, o nome do antigo proprietário é substituído pelo de um mártir ou santo querido daquele lugar.

Posteriormente, no tempo de Constantino, os títuli se transformam em basílicas. Um bom resumo desta evolução encontramos na obra 'Conflito em Roma', de Jeffers

Nos séculos I e II, os cristãos se reuniam em congregações domésticas pequenas e essencialmente autônomas. Como no judaísmo romano, existia pouca ou nenhuma organização central. Cada igreja doméstica decidia se se reunia em segredo total ou se de declararia associação voluntária. O modelo da sinagoga,

416 CASTELLUCCI, E. Essere comunità Cristiana oggi, op. cit. In: Nuove forme di comunità crisiana, op. cit., p. 71.

${ }^{417}$ ALMEIDA, J. A. Paróquia, comunidades e pastoral urbana, op. cit., p. 34.

${ }^{418}$ AGUIRRE, R. Del movimiento de Jesús a la Iglesia Cristiana: ensayo de exégesis socilógica del cristianismo primitivo. Estella: Verbo Divino, 2009, p. 107.

${ }^{419}$ ALMEIDA. J. A. Paróquias, comunidades e pastoral urbana, op. cit., p. 36.

${ }^{420}$ Cf. BERNARDINO, A. (org.). Dicionário de Patrística e Antiguidades Cristãs. Petrópolis: Vozes, 2002.

"Os títulos eram, pois 'Igrejas domésticas, como as de Rm 16, que se tornaram - com algumas 'variações acidentais' - centros regionais (na cidade de Roma) e, depois de Constantino, basílicas". JEFFERS. Conflito em Roma: ordem social e hierarquia no cristianismo primitivo. São Paulo: Loyola, 1995, p. 68. 
bem como o modelo de associaçãa ${ }^{421}$ e a lista de $\mathrm{Rm} 16$, sugere que cada congregação fosse governada por diversos líderes. As congregações adotavam, muito provavelmente, o nome de cristãos em cuja casa se reuniam. Novas igrejas domésticas surgiam espontaneamente de acordo com a necessidade, e outras periodicamente desapareciam ... Quando o cristianismo romano adquiriu a forma de uma organização central, começou a controlar a operação das Igrejas domestica locais usadas como centros administrativos ... Os tituli romanos preservam os locais de várias Igrejas domésticas do século II, algumas delas podendo datar até do século $\mathrm{I}^{422}$.

A realidade muda radicalmente, portanto, a partir do IV século, na chamada paz constantina, onde se tem início as paróquias territoriais ${ }^{423}$. Com o nascimento das basílicas, a partir do século IV, cessam as celebrações eucarísticas nas casas, que são transferidas para um lugar público de culto. Outra observação significativa a ser feita diz respeito à ministerialidade. Num segundo período da era apostólica, a partir do século II, as comunidades fora de Jerusalém começam a se estruturar com um grupo de anciãos, presidido por um superintendente que impunha as mãos para comunicar ordens sacras ${ }^{424}$. "Quando as comunidades cristãs começaram a aumentar, no século II, apareceram os bispos, os presbíteros e os diáconos, e se começou uma clara distinção entre os que exerciam um ministério e os simples fiéis. Os que dirigiam a Igreja eram chamados anciãos ou presbíteros e formavam um colégio chamado 'presbitério'. Tal colégio era presidido pelo bispo, que se distinguia gradualmente dos simples presbíteros" ${ }^{225}$.

No século III já está presente uma mudança decisiva na organização da Igreja, com a distinção ente clero e leigos, como se pode confirmar em Tertuliano e Orígenes ${ }^{426}$. A conclusão a que se chega é que no final do século III a estrutura

422 JEFFERS, J. S. Conflito em Roma: ordem social e conflito no cristianismo primitivo. São Paulo: Loyola, 1995, p. 69.

423 'O antigo equilíbrio entre 'Igreja da casa' (comunidade espiritual social) e 'casa da Igreja' ou simplesmente 'casa igreja' (pequeno espaço físico onde a comunidade se reunia), em certa medida abalada pela introdução dos 'títulos' (que, às vezes, eram ainda as casas-igrejas dos inícios, mas, geralmente, outros espaços: a sede de uma associação funerária, um armazém desativado, um cômodo amplo desocupado de uma casa etc), será praticamente dissolvido pela introdução das 'paróquias territorias', em que os limites entre comunidade eclesial e sociedade civil começaram a desaparecer, e a identificação entre 'paróquia e 'igreja paroquial' (no sentido de templo) começa a emergir". ALMEIDA, J. A. Paróquia, comunidades e pastoral urbana, op. cit., p 41.

${ }^{424}$ Cf. GIUSTINA, E. D. A paróquia renovada, op. cit., p. 39; Cf. At 11, 29-30; 14,23; Ef 4,11; Tt 1, 5; Pastor de Hermas, 2 vis. 4, 2; Clemente Romano, Epístola XLIV.

${ }^{425}$ Ibid., op. cit., p. 40. As primeiras fontes referentes a esta questão são de Tertuliano e Cipriano. No oriente a Didaskalia utiliza muito o vocábulo sacral.

${ }^{426}$ Cf. TERTULIANO. De Monogamia, XII, P1 II, 997; ORÍGENES: In: Ieremiam, XI, 3, PQ XIII, 369; S. JERÔNIMO. Epist. LII, 5; P1 XXII, 531. 
eclesiástica assiste a uma redução dos ministérios, a sacralização dos ministros e a separação entre a classe da ordem e da plebe ${ }^{427}$.

\title{
4.1.2
}

\section{Da Igreja das casas à estruturação da paróquia}

A abordagem anterior de certa forma já nos introduziu no nascimento da paróquia. A estruturação da paróquia remete ao século IV, quando o cristianismo experimenta um aumento prodigioso em número de fiéis. Se até o século III os lugares de culto eram as casas à disposição para a reunião da assembléia, é a partir do século seguinte que nascerão as paróquias e, no século $\mathrm{V}$, o seu florescimento $^{428}$.

Com o crescimento vertiginoso de cristãos em todas as partes do império romano, e com o surgimento de novas comunidades, sobretudo nas áreas rurais, a Igreja, até então centrada nas cidades, já não conseguindo fazer-se presente em todos os ambientes, se vê necessitada de atender os mais distantes. Viu-se a necessidade de repensar a atuação pastoral e buscar respostas eclesiais aos novos desafios.

\begin{abstract}
Multiplicar os bispos foi a solução africana; fazer corespíscopos, solução das Gálias e da Ásia; formar paróquia com um presbítero, solução romana. Este podia celebrar a missa, celebrar os sacramentos e educar o povo cristiamente, sempre com dependência do bispo. A sede passou a se chamar diocese, tomando o nome da divisão administrativa instaurada pelo Império romano, no tempo de Diocleciano $^{429}$.
\end{abstract}

Criam-se então novas comunidades, dividem-se outras, marca-se presença entre os mais afastados, agora fora da cidade. Surgem, assim, as paróquias para

\footnotetext{
${ }^{427}$ É no século II que se estabelece a distinção e separação entre ordem (ordenados) e o simples fiel (plebe). O termo ordo se referia à condição que cada um ocupava na sociedade ou à função que exercia. Para os cidadãos do Império se reconheciam três ordens: os senadores (ordo senatorius); os cavaleiros (ordo equester); o povo ou a plebe (ordo plebeius). Mas, na prática, ao se falar de ordo entendia-se com distinta da plebe. Eram, na verdade, só duas ordines: a plebe e os outros. Esta terminologia passou para a Igreja, que adotou os termos: clero e povo. Daí, por muito tempo a Igreja passou a ter duas categorias de pessoas: os ordenados (ordinati), a quem correspondia a honra, e o povo (plebs) cf. GIUSTINA, E, A. paróquia renovada, op. cit., p. 41; cf. CASTILLO, J. M. La comunidad y los ministérios, op. cit. In: Pastoral Misionera, 5, 1978, op. cit., pp. 41.

428 "Foi o Concílio de Calcedônia, em 451, que aprovou as leis sobre a constituição de paróquia e dos direitos e deveres dos seus responsáveis que ficavam dependentes do bispo". Cf. GIUSTINA, E. A. paróquia renovada, op. cit., p. 42.

${ }^{429}$ GIUSTINA, E. D. A paróquia renovada, op. cit., p. 42.
} 
poder atender aos pagi, pequenos agrupamentos rurais, uma vez que até então a igreja estava nas cidades.

Ao surgirem os núcleos de fiéis nos campos, para lá são enviados os auxiliares dos bispos, cuja principal função era a da pregação e administração de alguns sacramentos. Inicia-se desta forma um processo de descentralização da estrutura eclesial, ou seja, a passagem de uma configuração urbana, cujo modelo era a de 'comunidade episcopal', ou catedral, isto é, um bispo para cada cidade, e uma Igreja para cada cidade, auxiliados por presbíteros e diáconos ${ }^{430}$, para o modelo matriz com suas filiais espalhadas pelos campos. O século IV testemunha, portanto, a passagem de uma configuração urbana, 'catedrais ou comunidades episcopais' para uma organização rural. São os presbíteros que de agora em diante irão presidir as novas comunidades em comunhão com a sede episcopal ${ }^{431}$. $\mathrm{O}$ modelo eclesial - uma comunidade, um bispo, um altar, a igreja que está num lugar, e este lugar é a cidade - agora se vê espalhada sob os cuidados dos representantes do bispo, os presbíteros. Aos poucos tais presbíteros assumem autonomia e um progressivo distanciamento das 'catedras'. É no século IV, portanto, que assiste-se ao desenrolar gradual, mas constante, de uma nova forma de organização eclesial, cuja base é o território, que mais tarde receberá o nome de "paróquia" 432 .

Aquela unidade pastoral entre bispo, presbíteros e diáconos que trabalhavam em plena harmonia nas comunidades é desfeita em nome de um progressivo isolamento ministerial presbiteral. Ao final dos séculos V e VI, os presbíteros começam a se fixar no ambiente rural, e começam a ser chamados de 'sacerdos'. A figura do padre vai paulatinamente ganhando destaque, e a paróquia recebe uma certa autonomia. Paulatinamente iniciam-se as grandes construções para as celebrações, as quais até então eram realizadas preponderantemente nas casas. Com cristãos em massa, apoiados por Constantino, a Igreja recebe basílicas e constrói outras. Na sede episcopal de Antioquia, em 340, celebrou-se a

\footnotetext{
${ }^{430}$ Cf. ANDRADE, D. R. Reiventar a paróquia? Sonhar em tempo de incertezas. São Paulo: Loyola, 2006, p. 17.

${ }^{431}$ O presbítero passa a ser chamado 'sacerdos', o que antes era reservado somente aos bispos, apesar de continuar a permanecer de segunda ordem, em comparação aos sacerdos episcopus'. Cf. BORRAS, A. Le communautés paroissiales: droit canoniques et perspectives pastorales: Paris: Cerf, 1996, p. 15.

${ }^{432}$ Cf. ALMEIDA, J. A. Paróquia, comunidades e pastoral urbana, op. cit., p. 43.
} 
consagração de uma imponente basílica construída pelo imperador Constantino e seu filho. Nesta mesma data e no mesmo local, um concílio, com a participação de 87 bispos estabeleceu a seguinte norma: "Cada bispo é mestre de sua diocese, a qual deve governar, respeitando os direitos de cada um. Deve, igualmente, cuidar das comunidades rurais subordinadas à sua cidade episcopal, destinar-lhes padres e diáconos, procedendo em tudo com discernimento"433.

Em meio a todas estas transformações, diminui o espírito missionário, atropela-se o catecumenato, prevalece o batismo de crianças, além de outros retrocessos pastorais. Vale a pena enfatizar esta questão, a qual voltaremos posteriormente: o nascimento da paróquia terá incidência sobre a iniciação cristã, o catecumenato. A pertença à Igreja deixa de ser questão de opção pessoal. Nascese em uma família cristã, numa cultura, e numa sociedade cristã. a pertença a Igreja deixa de ser fruto da atividade missionária, mas consequência do nascimento: "nasce-se na Igreja como se nasce numa família, numa cidade, num país ${ }^{434}$.

Em suma, a partir do quarto século uma nova configuração eclesial começa a ganhar um corpo bastante definido, cujo modelo é o de Igreja-mãe com suas filiais instaladas em regiões distantes ${ }^{435}$, vigente até hoje. A estrutura eclesial eminentemente urbana, isto é, Igreja cidade, animada pelo bispo, presbítero e diáconos é substituída pelo modelo tipicamente rural.

Por volta do século décimo, a paróquia atravessa uma profunda crise política. Já totalmente no espírito de cristandade, a paróquia cai sob o domínio dos feudos. A arbitrariedade dos senhores feudais multiplicavam as paróquias, nomeavam os párocos com interesses de obter vantagem nas taxas, impostos e dízimos, instituídos por Carlos $\mathrm{Magno}^{436}$. Nas cidades aparecem várias paróquias; divide-se o território diocesano em paróquia. Nesta época as paróquias são propriedades dos senhores feudais. A relação entre párocos e fiéis é de direitodever, ou seja, os preceitos e obrigações são impostos aos fiéis.

\footnotetext{
${ }^{433}$ Cf. ANDRADE, D. Reinventar a paróquia, op. cit., 19-20.

${ }^{434}$ ALMEIDA, J. A. Paróquia, comunidades e pastoral urbana, op. cit., p. 47.

${ }^{435}$ Cf. ANDRADE, D. R. Reinventar a paróquia, op. cit., p. 19.

${ }^{436}$ Cf. COMBLIN, J. "A Paróquia ontem, hoje e amanhã”. In: A paróquia ontem, hoje e amanhã. Simpósio. Petrópolis: Vozes, 1967, p. 7.
} 
É o papa Gregório VII que consegue libertar a paróquia do domínio feudal e da simonia, porém ela nunca mais recuperou sua vitalidade pastoral. São os mosteiros e a vida religiosa, no século XII, o centro irradiador da fé cristã. Elas darão à vida cristã um impulso renovador. No século XIII aparecem os mendicantes, com Francisco de Assis e Domingo. Nesta época as paróquias exercem muito mais uma função administrativa do que pastoral. É nas igrejas dos frades que acontecem as devoções. Surgem as Ordens Terceiras, o catolicismo de irmandade ${ }^{437}$.

O concílio de Trento reforçou a centralidade da paróquia na vida da Igreja. Estimulou ao máximo a criação de paróquias a fim de atender as demandas. Afirma-se a divisão do território da diocese em paróquias, com limites geográficos, sacerdote próprio, o que modifica definitivamente a relação entre cidade e Igreja, mantida nas comunidades primitivas. São os religiosos que nesta época entram no coração das cidades. O Código de Direito Canônico de 1917, no canôn 1, vai confirmar a divisão.

No Brasil, no fim do Império as Ordens religiosas entram em decadência. Em 1855 o decerto imperial fecha os noviciados e a paróquia é a única presença da Igreja católica nas cidades do interior. Sozinhos, os vigários têm que se dedicar quase exclusivamente às questões administrativas e mal consegue cumprir os atos de preceitos religiosos ${ }^{438}$.

Tentativas de renovação ocorreram ainda antes do Concílio Vaticano II, na busca de uma efetiva presença cristã na sociedade, como exemplo, o 'Movimento litúrgico', o Movimento de Padres Operários, a Ação Católica.

A partir do Concilio Vaticano II, as paróquias ganham cada vez mais atenção e cresce a percepção da urgência de sua renovação. Vários são os documentos e decretos conciliares e pós-conciliares que trazem à tona a temática da vida paroquial. Enfim, importante é perceber que a atual instituição paroquial é resultado de mutações históricas. Vigente até os dias de hoje, o atual modelo paroquial, resultado de fatores socioculturais, foi implantado num contexto rural, num mundo já aos moldes da cristandade, que sem sombra de dúvida adaptou-se e respondeu às exigências de seu tempo. Contudo, hoje, diante de um contexto de

\footnotetext{
${ }^{437}$ Cf. Ibid. p. 8.

${ }^{438}$ Cf. Ibid. p., 6-9.
} 
alta e acelerada urbanização com todas as suas consequiências, tal modelo encontra dificuldades na transmissão de sua mensagem.

\section{2}

\section{A paróquia entre a desconfiança e a credibilidade}

Dentre as instituições que mais têm sentido os abalos das mutações sócio culturais está a Igreja, e nela a instituição paroquial. Não é de hoje a afirmação da crise da paróquia. Tornou-se comum, a partir das primeiras décadas do século XX, a afirmação da crise da instituição paroquial. Se até então ela não apresentava maiores sintomas, é a partir deste momento que se percebe a gravidade de seu estado, já não mais capaz de responder às exigências da nova cultura.

Tão logo a cultura urbana começou a se expandir, com maior ou menor intensidade, por todos os cantos do planeta, a paróquia, instituição adaptada ao ambiente rural e nascida num contexto de cristandade, começa a sentir-se como um objeto estranho em uma cultura que não é a sua.

A paróquia é questionada não somente neste ou naquele aspecto. É a totalidade de sua estrutura eclesial e pastoral que clama por renovação. Chegar à raiz do problema não é tarefa fácil, pois as razões de sua deficiência não são unilaterias, assim como não o são a busca de respostas. Apontar somente uma causa da assim chamada crise paroquial seria ingênuo, da mesma forma que inócuo seria reestruturá-la a partir de um único aspecto. Entram em cena aspectos múltiplos e de várias ordens, interna e externa à própria natureza paroquial.

O contexto sócio cultural e religioso, visto no primeiro capítulo, teve a intenção de situar tanto a iniciação cristã como a paróquia neste mundo que as desafia, mas que também as oportuniza. Por ser uma realidade encarnada na história, a paróquia não está isenta dos efeitos do atual momento sócio cultural. Todas as características da vigente sociedade pluralista lançam novas exigências à Igreja, que por sua vez se vê limitada com sua pastoral tradicional ${ }^{439}$. Entende-se, portanto, o porquê da debilidade paroquial nos dias de hoje, e da urgente necessidade de transformá-la em renovados canais de comunicação do Evangelho e em renovadas estruturas comunitárias.

\footnotetext{
${ }^{439}$ Cf. MIRANDA, M. F. A Igreja numa sociedade fragmentada, op. cit., p. 66.
} 
Certamente outros aspectos ad intra são igualmente responsáveis pelo mal- estar paroquial. Citemos, por exemplo, a diminuição do clero, as questões de ordem canônica, o modelo ministerial, a tensão clero-leigo, o autoritarismo de muitos párocos, a tensão unidade-pluralismo, a tensão paróquia território e território sócio-cultural, o que não significa que adentraremos em cada uma destas questões. Fundamental é perceber que o mal estar paroquial é resultado também da auto percepção do corpo eclesial de que algo não vai bem em si. A primeira a não estar satisfeita e a enxergar a incoerência entre as tarefas a ela atribuídas e sua realidade é a própria paróquia. "Um corpo eclesial que vê a paróquia atual incapaz de por em ato as potencialidades e os sonhos utópicos elaborados a seu respeito" ${ }^{440}$. Em outros termos, a paróquia, ela mesma se sente incomodada ao perceber que não é aquilo que é chamada a ser. Sabe haver um descompasso entre o que dizem os documentos eclesiais a seu respeito e sua real configuração. Parcela significativa da tensão da figura tradicional da paróquia se deve, portanto, ao feliz amadurecimento eclesiológico dos últimos anos que entende paróquia como 'comunidade de fiéis', 'comunidade cristã', 'célula de base da Igreja', 'Igreja local', 'assembléia eucarística', 'Igreja entre as pessoas', 'família de Deus', 'comunidade missionaria', 'comunidade alternativa'.

Sem a pretensão de esgotar todos os aspectos da crise paroquial ressaltaremos a seguir aqueles mais evidentes, e que direta ou indiretamente dizem respeito à iniciação à vida cristã. Condição necessária para entender a crise paroquial é perceber que vivemos o fim da civilização paroquial.

\subsection{1}

\section{Fim da civilização paroquial}

Nos parágrafos precedentes situamos a crise paroquial dentro do quadro das mutações culturais e religiosas em curso. É a partir desta realidade que se torna possível entender aquilo a que a expressão 'fim da civilização paroquial ${ }^{441}$ quer chamar a atenção. Trata-se do fim daquele mundo sólido, religioso e culturalmente organizado, sustentador da instituição paroquial, ao mesmo tempo em que era por ela legitimado. A realidade paroquial é hoje privada daquele fundo

\footnotetext{
${ }^{440}$ Cf. BRESSAN, L. La parrocchia oggi: identità, transformazioni, sfide. Bologna: EDB, 2004, p. 78.

${ }^{441}$ Cf. HERVIEU-LÉGER, D. Vers un nouveau christianisme? Cerf. Paris, 1987
} 
natural que lhe dava suporte ${ }^{442}$. Diante de um mundo em plena privatização religiosa a paróquia já não mais carrega consigo a prerrogativa reguladora que possuía na sociedade tradicional ${ }^{443}$.

Se não se pode falar com segurança de um provável fim da paróquia, reflexões importantes nos têm ajudado a admitir o fim de um modelo paroquial, ou se preferirmos, de um mundo, de uma organização, de uma lógica paroquial típica da cultura de cristandade, organizadora do todo social. Pode-se, então, afirmar a coincidência necessária entre fim da cristandade ${ }^{444}$ e o fim da 'civilização paroquial'. Como bem observa Floristán,

A paróquia herdada corresponde a uma modelo tradicional conservador, em coerência com os velhos senhores da sociedade rural. Goza de reconhecimento oficial pela sua tendência para a verticalidade autoritária, por se sentir salvaguarda da coesão moral e da ordem, pelas suas competências administrativas e pela sua docilidade gregária, traços que são característicos da pastoral de cristandade ${ }^{445}$.

Apesar de toda boa vontade, esforço e criatividade de inúmeros evangelizadores, não se pode negar que a paróquia é uma instituição herdada da cristandade, conservando-se praticamente imutável até os dias de hoje, o que torna inevitável o choque com a cultura hodierna. Imutável há séculos, com dificuldades de entrar na lógica urbana, ela sente-se pouco à vontade nos grandes centros $^{446}$. O descompasso entre os mecanismos que regem a atual sociedade e o paradigma paroquial vigente estimula o desabafo do teólogo Comblin: "a paróquia sobrevirá até que desapareçam os últimos representantes da antiga cristandade" ${ }^{\natural 47}$.

A atual realidade paroquial é resultado de uma configuração criada dentro de um quadro cultural onde comunidade sociocultural e território se identificavam. Em um ambiente onde catolicismo e cultural, espaço geográfico e

${ }^{442}$ BRESSAN, L. La parrocchia oggi, op. cit., p. 79.

${ }^{443}$ Cf. SORAVITO. L.; BRESSAN, L. Il Rinnovamento della parrocchia in una società che cambia. Padova: Messaggero di Sant'Antonio, 2007, p. 15.

444 As palavras de ZULEHNER favorecem uma melhor compreensão de cristandade: "Na cristandade, a relação entre cidadãos e Igreja é social e estatalmente predefinida: Estado e Igreja, enquanto autoridades civil e espiritual, prescrevem, de comum acordo, a pertença e a medida da participação exigida em relação à fé e à vida da Igreja. Isso é facilitado pela estrutura de uma sociedade ordenada hierarquicamente por 'estados', aliás, talvez só isto o torna possível. Em virtude de convenções sociais, o Estado e a Igreja, apoiando-se reciprocamente, podem, por isso, impor as suas exigências, com todos os meios à disposição". ZULEHNER, P. M. Teologia Pastorale. V. 1: pastorale fondamentale. Brescia: Queriniana, 1992, p. 166.

${ }^{445}$ FLORISTÁN, C. Para compreender a paróquia. Gráfica de Coimbra, p. 20.

${ }^{446}$ Ibid., p. 19.

${ }^{447}$ COMBLIM, J. Os desafios da cidade no século XXI. 2. ed. São Paulo: Paulus, 2002, p. 48. 
espaço da fé estavam unidos, tal modelo eclesial não fornecia maiores problemas à vivência comunitária. Por séculos tal estrutura respondeu às necessidades de seu contexto, adaptou-se muito bem ao mundo da época, mas "a situação mudou e o sistema sobreviveu. Hoje é apenas anacronismo: anocronismo que mantém, por outro lado, na pastoral, certo ruralismo difícil de vencer", observa Comblim ${ }^{448}$.

Verifica-se, portanto, a queda daquele fundo natural de que gozava a paróquia, entre cujos sinais evidentes está a diferença entre dois perfis religiosos, o primeiro típico da 'civilização paroquial', e o segundo, da atualidade. As já mencionadas figuras do praticante e do peregrino são, na intuição de HervieuLéger, figuras típicas de dois mundos religiosos diferentes que expressam, por sua vez, diferentes relações com a paróquia. O peregrino sugere em primeiro lugar movimento, experimento, busca, procura. Daí ser ele o exemplo cristalino do sujeito religioso de nossos dias que se sente na liberdade de transitar entre os vários credos na busca de experiências religiosas gratificantes ${ }^{449}$. O quadro comparativo da mesma autora ilustra com clareza a diferenciação dos dois perfis religiosos em questão. O praticante: prática obrigatória, fixa, comunitária, territorialmente delimitada (estável), ordinária, costumeira, repetida. O peregrino: voluntária, autônoma, moldável, individual, desterritorializada, móvel, extraordinária, excepcional, ocasional ${ }^{450}$.

A figura exemplar do praticante regular e fiel deixa de ser o padrão de referência de paroquiano. A dinâmica da conformidade e obrigatoriedade cede lugar a práticas voluntárias descompromissadas, conforme revela o depoimento de um jovem: "Sou católico, vou à missa aos domingos. Bem, nem sempre: há alturas em que não tenho vontade, isso não me diz nada ${ }^{451}$ " Trata-se, enfim, de um novo jeito de ser religioso, fluido, livre, espontâneo, o que significa uma nova relação com a paróquia, uma vez que está é a referência primeira da religião. Desafio incomensurável compreender o religioso e a paróquia a partir da mobilidade, uma vez que por séculos esta foi marcada por uma realidade estática.

\footnotetext{
${ }^{448}$ COMBLIM J. Teologia da cidade, op. cit., p 188.

${ }^{449}$ Cf. HERVIEU-LÉGER, D. O peregrino e o convertido, op. cit., p. $18 \mathrm{ss}$.

${ }^{450}$ Cf. Ibid., p. 109. Uma ressalva é oportuna para mostrar o aspecto interessante da pastoral paroquial ao colocar em interação os praticantes e os não praticantes, se interpelando mutuamente e mútuo conhecimento, reconhecimento de estar junto, ainda que de maneira diferente. Cf. BORRAS, A. Appartenance à l'Église ou itinérance ecclesiale? (Pertença à Igreja ou itinerância eclesial? Lumen Vitae, v. 48, n. 2, juin 1993 (pp. 161-173).

${ }^{451}$ Cf. HERVIEU-LÉGER, D. O peregrino e o convertido, op. cit., p. 96.
} 
No âmbito do catolicismo, é a 'civilização paroquial', portanto, quem mais sente os efeitos das transformações religiosas. Desde seu início, a paróquia foi o representante máximo da religiosidade fixa assim como a figura do praticante regular sempre definiu o rosto da religiosidade paroquial ${ }^{452}$.

$\mathrm{Na}$ mesma intuição da assim chamada 'fim da civilização paroquial', Bressan, teólogo italiano e de vasta experiência paroquial, propõe três dimensões da crise da paróquia ${ }^{453}$. 1) A crise de representação, visivelmente percebida na diminuição da prática cristã, na diminuição do clero, na perda do espaço social e na capacidade de ritmar a dinâmica social daquele território, na perda da garantia da ordem social e da escala de valores, e da autoridade de referência. Em uma palavra, a paróquia não garante nem é mais referência para a ordem social. O ritmo da vida social não é mais circunscrito ao redor da paróquia, pois não vigora mais o trípice espaço social: paróquia - Igreja - praça. Numa palavra mais plausível, a paróquia sente a perda do centro, o que lhe exige necessariamente uma nova relação com o conjunto da cidade, ou se preferirmos, com a cultura urbana. 2) A crise de significado, que dentro das mutações religiosas e culturais, já exaustivamente visto, faz a paróquia perder o princípio regulador das necessidades religiosas daquele lugar. A relação paróquia-fiel tende a ser predominantemente de cunho de serviços religiosos. 'Para que' serve a paróquia a não ser para a busca de serviços, e na maioria das vezes sacramentais? 3) E por fim, a crise de identidade, por não apresentar aquelas características de comunhão, de missionariedade, de corresponsabilidade ministerial que o Concilio lhe atribui.

Posto isto, apontaremos três aspectos que mais diretamente traduzem a crise da configuração paroquial.

\subsection{2}

\section{Paróquia: uma instituição de massa}

Dentre as várias dimensões da crise paroquial é, sem dúvida, o aspecto comunitário o que mais desafia a paróquia a repensar sua configuração. Aqui reside uma das principais, senão a maior vulnerabilidade de uma instituição eclesial que é chamada a ser 'célula base da Igreja', 'escola de comunhão', 'Igreja

\footnotetext{
${ }^{452}$ Cf. Ibid., p. 99.

${ }^{453}$ BRESSAN, L. La parrocchia oggi, op. cit.; BRESSAN, L. Cos'è (oggi) la parrrocchia. In: Ripensare la parrocchia. Ed. Dehoniane, 2004, pp. 81-113.
} 
entre a casa dos homens', quando na realidade se configura mais como uma Igreja de massa.

É inquestionável que o modelo atual de paróquia aproxima-se mais de uma sociedade do que comunidade, exceto para uma parcela muito reduzida de fiéis, quase sempre os mais engajados pastoralmente, que ainda conseguem um relacionamento mais próximo entre si. Com outras palavras, a paróquia, na atual configuração, assemelha-se mais a um aglomerado social com todas as características de uma sociedade institucionalizada ${ }^{454}$.

A diferença entre comunidade e sociedade tem sido vastamente trabalhada por sociólogos, os quais, mormente descrevem a comunidade com características bastante definidas, entre as quais se destacam as relações interpessoais, certo grau de intimidade, de partilha e participação, ao passo que por sociedade entende-se formas de relacionamentos impessoais e com menor grau de partilha de valores e objetivos comuns. A comunidade conta com elevado grau de integração afetiva e coesão entre seus membros, que compartilham conhecimentos, objetivos, práticas cotidianas, valores, formas de agir e pensar. Enquanto que nas comunidades os membros têm relações diretas e pessoais, solidariedades afetivas e comuns, sem regulamentações jurídicas, numa sociedade as relações são indiretas, cuja solidariedade nasce de objetivos racionais, e com a necessidade de meios para atingi-los. As relações são baseadas em regras convencionais. Comunidade é, portanto, uma associação vital orgânica, fruto de uma vontade natural, cujas características são de intimidade, partilha, confiança, solidariedade. Sociedade, ao contrário, seria resultado da soma dos indivíduos, não voluntária, e sim artificial. Comunidade e sociedade se distinguem, sobretudo pelo 'nós' que atrai e une o grupo. Distinguem-se ainda pela capacidade de dar reconhecimento ao sujeito, que deseja ter sua personalidade reconhecida, de poder exclamar: 'aqui eu sou gente.

Conhecidas são as contribuições de Mafessoli sobre o fenômeno das comunidades pós-modernas, descritas pelo autor como novas 'tribos' ou 'guetos'. Vivemos em um período histórico em que ocorre um hibridismo de estilos de vida, em que as diversas características ofuscadas na modernidade estão voltando

${ }^{454}$ Cf. ALMEIDA, J. A. Paróquia, comunidades e pastoral urbana, op. cit., p. 183. 
à tona, sendo reintegradas ao social, e isso inclui diretamente o 'tribalismo', como nova forma de vivência comunitária. Em meio ao individualismo pós-moderno há sim um fenômeno comunitário, na análise de Mafessoli. "Participando de uma multiplicidade de tribos, as quais se situam umas em relação às outras, cada pessoa poderá viver sua pluralidade intrínseca; suas diferentes "máscaras" se ordenando de maneira mais ou menos conflitual, e ajustando-se com as outras "máscaras" que a circundam" 455 .Tais tribos, mesmo contando com membros passageiros e sendo elas mesmas passageiras, não se pode negar que conferem um sentido comum e mostram-se como uma reconstrução da vida comunitária. Percebe-se, portanto, na visão de Mafessolin certo grau de otimismo, diferentemente de Bauman, para quem as formas comunitárias hodiernas são quase sempre líquidas, 'comunidades estéticas ${ }^{356}$. Seja qual for a análise em voga, o que não se pode negar é a necessidade antropológica de convivência e contatos mais próximos, num nível mais profundo do que aquele de massa. Não deixa de chamar a atenção os dados do último senso religioso do país, que ao mostrar o crescimento do pentecostalismo, revelam que dentre eles são a multiplicação de pequenas Igrejas as que mais crescem. Certamente entre outras razões do fenômeno está o fator numérico onde o contado pessoal é facilitado.

Feitas as devidas distinções entre as duas realidades sociológicas, comunidade e sociedade, com mais propriedade pode-se agora ratificar a afirmação feita no início deste tópico. A atual configuração eclesial paroquial há tempo carece caráter comunitário, razão primordial de sua crise. O alto grau de institucionalização de que a paróquia é vitima dificulta relações mais familiares e espontâneas. Neste sentido, as mutações culturais atingem a paróquia naquilo que ela tem de mais essencial, ou se preferirmos, em sua identidade mais profunda. Comunidade sempre foi para a paróquia sua identidade. Enquanto que o institucional, o território são realidades circunstanciais e históricas, a comunidade é para a paróquia uma questão teológica, por isso mesmo irrenunciável ${ }^{457}$. Todas as mudanças estruturais da paróquia ao longo da história tiveram a preocupação

\footnotetext{
455 MAFFESOLI, M. O tempo das tribos: o declínio do individualismo nas sociedades de massa. Rio de Janeiro: Forense Universitária, 2006, p. 238.

${ }^{456}$ BAUMAN, Z. Modernidade líquida, op. cit.

${ }^{457}$ AMADO. J. P. Experiência eclesial em mundo urbano: pressupostos e concretizações $\left(2^{o}\right.$ parte), op. cit. In: Atualidade Teológica, v. 9, op. cit., p.161.
} 
de garantir a vivência comunitária da fé. Quando não consegue mais acompanhar as comunidades fora da cidade, a Igreja vai, então, para o campo formar comunidades. Reside aqui igualmente o sentido etimológico da paróquia, a Igreja que se encontra ao redor da casa, isto é, ao redor de onde as pessoas estão ${ }^{458}$.

O sentimento de pertença, as relações espontâneas e afetivas, tão centrais para o homem pós-moderno, não são o lado forte da paróquia. Para muitos a paróquia não passa de um lugar na cidade onde se pode assistir à missa ${ }^{459}$. Identifica-se ela mais a uma prestadora de serviço religioso, onde reinam relações impessoais, ou ainda, a uma entidade jurídica com fins religiosos ${ }^{460}$. Se formava comunidade no mundo rural, lá onde os pressupostos eram distintos dos atuais, hoje a configuração comunitária da paróquia já não consegue mais ser o espaço de pessoas que, unidas pela fé, partilham a própria vida. A atual configuração bi milenar não corresponde ao teologal comunidade, por não ser o lugar, senão de uma pequena parcela, da iniciação à vida cristã, da experiência comunitária, da participação ativa e responsável, da formação cristã permanente, da celebração da fé, da transformação da vida e da consciência, da solidariedade, do compromisso sociotransformador.

A pergunta central a ser feita é se pode hoje a paróquia ser uma comunidade eclesial ${ }^{461}$. Nesta perspectiva, o mito comunitário paroquial desenhado pelo Vaticano II e pelos documentos pós conciliares aponta muito mais para uma meta a ser alcançada do que uma realidade já existente. $\mathrm{O}$ futuro da paróquia dependerá muito do tecido comunitário que conseguirá formar. Um documento do Conselho Presbiteral de Madrid afirma que "reconhece-se que uma via eficaz para a renovação comunitária da paróquia é a criação de uma ou várias

\footnotetext{
${ }^{458}$ Cf. MACCHIONI, G. L. Évangelization dans l'oikos. Nouan-le-Fuzelier: Pneumathèque, 1996, pp. 53-65. Em sua origem, o termo paróquia vem do substantivo grego, paroikía e do verbo paroikêin, que significa viver junto a, ou habitar nas proximidades. Pairokos se refere a vizinho. No Novo testamento a palavra paróquia aparece somente duas vezes At 13,17 e 1 Pd 1,17 referindo-se como no Antigo Testamento ao estrangeiro, não possuidor dos direitos da cidadania. Assim, paróquia se refere tanto ao fato da comunidade cristã em si, reunida, como à transitoriedade da existência humana neste mundo.

${ }^{459}$ Cf. DEELEN, G. Pode a paróquia urbana ser uma comunidade? In: Revista Eclesiástica Brasileira. Petrópolis: Vozes, v. 25, fasc. 9, 1965, pp. 49-58.

${ }^{460}$ Cf. Ibid., p. 56.

${ }^{461}$ Cf. Ibid., pp. 49-58.
} 
comunidades-fermento, que sejam como que o núcleo animador da própria instituição paroquial" 462 .

\subsection{3}

\section{Paróquia: uma instituição territorial}

O fim da 'civilização paroquial' traz à tona a realidade de a paróquia não ser mais o dispositivo central daquele determinado território. Impõe-se com velocidade novas práticas territoriais, nas quais coabitam tempos e espaços diferentes e simultâneos. O território é um conjunto complexo de trânsitos, haja vista o esvaziamento dos centros aos finais de semana ${ }^{463}$.

Quanto maior o grau de urbanização tanto maior a mobilidade e a desvinculação com o território e com os espaços delimitados. A facilidade de locomoção permite romper com as relações tradicionais e fixas. Os limites jurídicos não só são ultrapassados com também diversas cidades coexistem dentro de uma mesma cidade. Nesta nova lógica, urge distinguir território geográfico e território sociocultural, pois hoje, em condições históricas diferentes, o sujeito constrói sua identidade prescindindo do território ${ }^{464}$.

No tocante às experiências religiosas, verifica-se com extrema facilidade que essas se dão muito mais a partir da proximidade de interesses do que pelos critérios geográficos, sem falar da multiplicação das pertenças eclesiais simultâneas. Portanto, consolida-se uma nova relação paróquia-território. Praticase a religião em nível de cidade: participa-se na missa numa determinada Igreja, confessa-se em outra, forma-se um grupo de oração numa terceira, e assim tantos outros freqüências quanto o interesse permitir, na busca de multiplicidade de contatos e com diversas redes de pertença.

\footnotetext{
${ }^{462}$ Cf. CONSELHO PRESBITERAL DE MADRID. Las comunidades eclesiales, 16 de Novembro de 1981.

463 "Os cidadãos percorrem nela espaços diferentes e, por isso, pertencem a vários grupos sociais que correspondem a outros tantos territórios ou itinerários, a mobilidade, por conseguinte, não é unicamente espacial, mas de ordem cultural e faz que as pessoas de hoje vivam em diversas redes de pertença. Esta multiplicidade de lugares onde se realizam as diversas atividades, implica uma multiplicidade de redes relacionais e uma multiplicação de 'territorialidades', pelo que os nossos contemporâneos mostram refratários a qualquer tentativa de os enquadrar". BORRAS, A. A remodelação paroquial. In: BORRAS, A.; ROUTHIER, G. A nova paróquia, op. cit., pp. 112-113. ${ }^{464}$ Cf. AMADO, J. P. Experiência eclesial em mundo urbano ( $2^{\circ}$ parte), op. cit. In: Atualidade Teológica, v. 9, op. cit., p. 161.
} 
Em nenhum momento queremos afirmar o não valor do território, seja para a paróquia em particular seja para a Igreja em geral. Ao contrário, sabemos que não existe Igreja senão em um lugar concreto. Por meio de um território, a paróquia visualiza a Igreja neste ou naquele lugar. Não se nega a necessidade da territorialidade para ancorar a memória cristã naquele espaço, estabelecer laços e tornar possível a transmissão da fé. A título de exemplificação da pertinência do território para a pastoral paroquial pode ser citado o fato de a paróquia não ser seletiva, mas abertas a todos daquele espaço, pois "a paróquia é a Igreja de portas abertas num lugar fixo" ${ }^{\prime 465}$.

A história nos ensina que sempre houve íntima relação entre paróquia e território, desde sua origem, e confirmada em Trento, o que não significa que a questão seja isenta de dificuldades, sobretudo hoje, em tempo de intensa mobilidade. Ao mesmo tempo em que conserva seu significado pastoral, o limite territorial tem sido promotor de entraves na ação evangelizadora. Em oposição ao atual contexto urbano, essencialmente desterritorializado e avesso à estabilidade, a atual configuração paroquial esbarra no dilema de sua jurisdição territorial. Reside aqui, sem sombra de dúvida, uma das principais tensões paroquiais, tensão essa que torna o anúncio de Jesus Cristo mais lento à cultura urbana. Enquanto que a cultura moderna está se tornando cada vez mais uma grande teia global nos deparamos com ação pastoral segmentada onde cada paróquia tornar-se uma ilha, e os padres, senhores absolutos. Mobilidade, subjetividade, diversidade, funcionalidade, são conceitos chaves na nova lógica de habitar e compreender o território.

A paróquia é uma instituição estruturada dentro da dinâmica territorial, isto é, uma comunidade que se identifica com o território onde vivem seus membros. O critério de ereção de uma paróquia ainda é o territorial. Dito diferente, a paróquia está constituída a partir de um território determinado, aos cuidados de um pároco, responsável pelos seus paroquianos, que a eles deve administrar os sacramentos.

As palavras de Brambilla proporcionam uma melhor compreensão do dilema em questão:

${ }^{465}$ PANNET, R. La paroisse de l'avenir. L'avenir de la paroisse. Fayard. Paris, 1979, p. 135. 
Se a paróquia fecha a experiência de fé em um espaço e em um tempo muito restrito corre o risco de apagar a sua dimensão missionária; se a paróquia se afasta do território, pode esquecer que o evangelho é anunciado não como uma mensagem jogada aos quatro ventos, mas para que faça surgir uma visível comunidade ${ }^{466}$.

Inadmissível é que o princípio territorial da paróquia não se deixe provocar pelas novas práticas territoriais, alargando-se e buscando novas possibilidades de habitar o espaço.

Num mundo de ações globais, também as referências eclesiais devem ter uma certa dose de globalidade, respeitando, sem dúvida, as peculiaridades de cada contexto. Tempos de mobilidade pedem, da ação evangelizadora, mais atenção às formas ambientais de pertenç $\mathrm{a}^{467}$.

O que está em jogo é a necessidade de pensar outras possibilidades de paróquia, que esteja mais de acordo com o ambiente citadino ${ }^{468}$. Quando o território representa um limite ou se ressume a uma mera delimitação geográfica, torna-se problemático, porém quando a partir da flexibilidade consegue alargar-se e se aproximar do território antropológico, então, "a paróquia é um lugar privilegiado onde os fiéis podem fazer a experiência concreta da igreja”. João Paulo II Ecclesia in America, 41. Sem fazer da paróquia um gueto, não se pode deixar de lado de lado as motivações religiosas pessoais e subjetivas, o lugar onde a pessoa foi iniciada na fé, o grau de identificação e outras questões que na sociedade atual determinam o cotidiano.

\subsection{4}

\section{Agência de prestação de serviço religioso}

Como desdobramento do dilema sociedade x comunidade, entra em cena a tensão comunidade $\mathrm{x}$ agência de serviços religiosos de que sofre a paróquia na atual conjuntura religiosa. De um lado, a paróquia se confronta com novos personagens que a 'frequentam' em busca de serviços especializados, tornando-se

466 BRAMBILLA, F. G. La parrocchiaa oggi e domani. Assisi: Editrice, 2004, p. 51

${ }^{467}$ AMADO, J. P. Viver e transmitir a fé no mundo urbano. In: CELAM. Testigos de Aparecida. Secretaria Geral. Bogotá, 2008, p. 386.

${ }^{468}$ Cf. AZEVEDO, W. O. Paróquia, cidade e evangelização. In: Rhema, Belo Horizonte, 1997, p. 35 . 
assim refém da vigente lógica de relações de serviços, o que significa mais uma vez o comprometimento da dimensão comunitária. Por outro lado, persiste a tendência sacramentalista da ação pastoral paroquial, o que não significa necessariamente iniciação à vida cristã, embora os sacramentos sejam momentos centrais da caminhada de fé. Em outros termos, a instituição paroquial configurase como uma instituição sacramental, pois seus principais esforços estão na direção dos sacramentais, como bem lembram ROUTHIER

A paróquia está, pois, situada no meio de um conjunto mais vasto de instituições que prestam serviços aos cidadãos, os quais se lhe dirigem para solicitar uma série de serviços especializados em matéria religiosa (batismo, primeira comunhão, confirmação, matrimônio, funerais, etc), tal como se dirigem a outras instituições para obterem pontualmente um determinado serviço especializado ${ }^{469}$.

Fato é que os cidadãos emancipados desejam beneficiar-se destes bens simbólicos, mas verifica-se a tendência de ter acesso livre e incondicional aos serviços sem a obrigação de pertencer a um grupo $^{470}$. Neste particular, as categorias de 'praticantes e peregrinos' sugeridos por HERVIEU-LÉGER revertem-se aqui dos traços de fornecedores-beneficiários, isto é, de um lado uma instituição que detém determinados serviços, bens, diga-se sacramentos, que são administrados por pessoas especializadas, qualificadas (clérigos) que atendem às necessidades espirituais dos fiéis. O agravante está no sistema desigual resultante daí:

Há sujeitos ativos (os recursos humanos pastorais) que efetuam ações pastorais, e clientes limitados ao consumo dos bens espirituais ou religiosos proporcionados pelos primeiros. Muito pouco se progrediu para uma igreja de sujeitos na qual cada um participa ativamente ${ }^{471}$.

Não é periférica, portanto, a tendência cada vez maior de a paróquia ser reduzida a prestação de bens simbólicos, como um grande serviço público

\footnotetext{
${ }^{469}$ ROUTHIER, G. A paróquia: suas imagens, seus modelos e suas representações, op. cit. In: BORRAS, A.; ROUTHIER, G. A nova paróquia, op. cit., p. 55. Aprofunda a questão o eclesiólogo Almeida: "seus lugares de culto são evidentes: o templo, para as celebrações rotineiras e festivas; o altar, para a oferta do sacrifício; o sacrário para a reserva eucarística e a adoração dos fiéis; o batistério, para acolher e incorporar os novos cristãos à Igreja; o confessionário, para atender os penitentes; na Europa e, em parte, nos Estados Unidos, o cemitério, tradicionalmente integrado à paróquia, para a sepultura dos fiéis". ALMEIDA, J. A. Paróquia, comunidades e pastoral urbana, op. cit., p. 77-78.

${ }^{470}$ Cf. ROUTHIER, G. A paróquia: suas imagens, seus modelos e suas representações, op. cit. In: BORRAS, A.; ROUTHIER, G. A nova paróquia, op. cit., p. 56.

${ }^{471}$ Ibid., p. 59.
} 
religioso $^{472}$. Toda atenção pastoral a fim de não adentrar por tais caminhos faz-se fundamental. Embora cresça a consciência atual da missão da igreja e sua identidade missionária, é grande o perigo de entrar pelos caminhos sedutores da lógica do consumo religioso, haja vista nos últimos anos a linguagem pastoral presente em certos setores eclesiais: 'pessoal pastoral', 'recursos humanos pastorais $^{, 473}$. Fato é que a Igreja não pode permitir que vigore a lei da oferta e procura, pois sua missão está muito além desta relação mercantil.

O que está em jogo é a relação que se estabelece entre Igreja-fiel. Não consiste novidade afirmar que qualquer relação de cunho individualimstamercantilista contrasta radicalmente com a proposta da iniciação cristã catecumenal, para a qual só se pode falar de iniciação quando estiver garantido, como um único processo, o mergulho no mistério e na comunidade eclesial, por isso, iniciação à vida cristã.

\section{3}

\section{Teologia, identidade e missão da paróquia}

Refletidos na primeira parte da tese os desafios da iniciação à vida cristã e o novo paradigma de transmissão da fé, com atenção especial ao modo catecumenal de iniciar na fé, adentramos nos elementos teológicas da iniciação. A mesma dinâmica será seguida no tocante à paróquia. Trouxemos a história desta instituição, os principais elementos estruturais e pastorais de sua crise, e agora interessa-nos seus elementos teológicos.

\subsection{1}

\section{Identidade e missão da paróquia}

A pergunta pela identidade da paróquia é relativamente recente no debate teológico-pastoral. Os primeiros passos da reflexão foram dados a partir da primeira metade do século $\mathrm{XX}$, quando a paróquia era, até aquele momento, concebida como uma entidade administrativa, jurídica e territorial.

\footnotetext{
472 Ibid., p. 55.

${ }^{473}$ A evolução da paróquia mostra com clareza o perigo dela adentrar pelos caminhos da lógica de serviços religiosos: em meados da década de $70 \mathrm{em}$ diante o acento posto nas instalações de escritórios e secretarias, salas de reunião e para e outros serviços especializados. "Neste conjunto, a figura da secretária torna-se cada vez mais preponderante ... A compra do mobiliário necessário para os escritórios e salas de reunião, supera em muito tudo o resto, inclusive a aquisição de bens relacionados com a função litúrgica da paróquia”. Ibid., pp. 61-62.
} 
Entre os muitos autores que contribuíram para um aprofundamento da reflexão dos fundamentos teológicos da instituição paroquial, destacam-se Rahner e Yves Congar. O primeiro chamou a atenção para a relação entre celebração eucarística e paróquia como expressão da Igreja. Congar, por sua vez, destacou a natureza missionária da paróquia, que permite a encarnação e proximidade da salvação em um lugar concreto, para a pessoa ${ }^{474}$. Segundo Congar, "a paróquia é o espaço da geração e da formação do ser cristão" 475 . Sua principal função é a de "gerar e formar cristãos" " Congar destaca ainda a dimensão de mistério da Igreja, quando a ênfase estava em sua dimensão hierárquica-instituicional. Para o teólogo francês, a Igreja não é apenas instituição, mas fundamentalmente comunhão $^{477}$.

Em continuidade à reflexão iniciada no contexto supracitado, o Concílio Vaticano II representa na reflexão teológica da paróquia uma guinada histórica. É o Vaticano II que oferece uma nova sensibilidade para repensar a instituição paroquial como comunidade cristã. Através de uma rápida visita aos textos conciliares perceberemos um certo mito comunitário paroquial ${ }^{478}$, o qual, todavia, deve ser olhado com cautela quando confrontado com a realidade ${ }^{479}$.

É bem verdade que o Concílio não oferece um estudo sistematizado nem um documento específico dedicado exclusivamente à paróquia, entretanto, em vários deles é possível captar sua rica identidade e natureza missionária. Grosso modo, pode-se afirmar que a eclesiologia do último Concílio aplica-se igualmente à instituição paroquial, sobremaneira os aspectos relacionados à Igreja local, muito embora a paróquia não seja a Igreja local, mas dela se aproxima de tal

\footnotetext{
${ }^{474}$ Cf. MARGHIGLIONI, E. M.; MEDDI, L. Il futuro della parrochia; guida alle trasformazioni necessarie. Milano: Paoline, 2006, p. 195.

${ }^{475}$ CONGAR, Y. Misión da la parroquia. In: Sacerdocio y laicado. Estela: Barcelona, 1964, 163 (original de 1948), citado por FLORISTÁN, A paróquia, op. cit., p. 28.

476 Ibid., p. 168.

${ }^{477}$ Cf. CONGAR, Y. M. Vraie et fausse reforme dans l'Église. Paris: Cerf, 1968, p. 15.

${ }^{478}$ Aparece 183 vezes o termo communitas nos textos do Vaticano II. Vale lembrar que o sentido é amplo, ou seja, designa a paróquia, diocese e até mesmo a Igreja geral. Quando os textos conciliares utilizam a expressão 'comunidade cristã', a tendência é substituir o termo paróquia, veja, por exemplo, o número 30 de Christus Dominus. Uma excelente diferenciação dos significados que os textos do Concílio atribui a termos como paróquia, comunidades eclesiais, comunidade cristã, comunidade, pode ser visto nas notas 11 a 14 de ROUTHIER, G. A paróquia: suas imagens, seus modelos e suas representações, op. cit. In: A Nova Paróquia. BORRAS, A.; ROUTHIER, G., op. cit., p. 34.

${ }^{479}$ Cf. ROUTHIER, G. A paróquia, op. cit. In: A Nova Paróquia. BORRAS, A; ROUTHIER, G., op. cit., pp. 32-33.
} 
forma que é definida como 'célula da Diocese' (AA n. 10). Queremos chamar a atenção para a íntima aproximação entre paróquia e Igreja local, cuja relação é de semelhança e interdependência. Enquanto que a diocese é porção do Povo de Deus que se confia aos cuidados pastorais de um bispo, a paróquia é parte da Igreja local. Portanto, em sentido estrito, paróquia não é Igreja local, mas nela se encontram todos os elementos eclesiais da Igreja e da Diocese, ou seja, fé, comunhão, Palavra, caridade, sacramentos, eucaristia, ministerialidade, carismas. Se na paróquia não está o bispo, o vínculo com ele é garantido pela figura do pároco. Ao se falar de paróquia se está falando de uma realidade eclesial própria e verdadeira, isto é, o conjunto das características da Igreja está presente na paróquia $^{480}$. Ao mesmo tempo, vale sempre ressaltar que a paróquia não se encerra em si mesma; está voltada para uma comunhão maior, a Igreja local, e através dela com a Igreja universal. Eis, portanto, porque ela é considerada 'célula da diocese'.

É a paróquia uma comunidade que concretiza o mistério de comunhão que é a Igreja. É uma comunidade de fé, uma comunidade eucarística, uma vez que a eucaristia é o centro da vida paroquial; uma comunidade ecumênica, porque aberta a todas as instâncias. É ela a concretização da Igreja local por possuir todos os elementos da mesma. Ecumênica no sentido de estar aberta a todas as pessoas, condições social e econômica, sem qualquer distinção ${ }^{481}$.

A Exortação Apostólica Christifideles Laici afirma que a paróquia é expressão 'mais imediata e visível' da comunhão eclesial. “A comunhão eclesial, embora conservando sempre a sua dimensão universal, encontra a sua expressão mais visível e imediata na paróquia. Ela é a ultima localização da Igreja que vive na casa de seus filhos e filhas" (CL, 26). A paróquia torna visível a Igreja universal, além de ser a expressão mais básica e elementar da Igreja. A paróquia "representa em certo modo a Igreja visível espalhada sobre toda a terra" (SC, 42).

Como nem sempre e em todos os lugares o bispo, em sua Igreja, pode estar pessoalmente à frente do rebanho todo, deve necessariamente organizar comunidade de fiéis. Entre elas sobressaem as paróquias, confiadas a um pastor local que as governe, fazendo às vezes do bispo (...) Haja esforço para que

\footnotetext{
${ }^{480}$ MARGHIGLIONI, E. e MARIELLA; MEDDI, L. Il futuro della parrocchia, op. cit., p. 196. ${ }^{481}$ Cf. GIUSTINA. E. D. O serviço da Igreja: breve curso de teologia pastoral fundamental. Aparecida: Santuário, 1993, p. 41.
} 
floresça o espírito de comunidade paroquial, mormente na celebração comunitária da missa dominical (CL, 42).

João Paulo II, na já mencionada Exortação Apostólica, diz que a Paróquia está fundada sobre a uma realidade teológica, a eucaristia. "Significa que é uma comunidade idônea para celebrar a eucaristia, na qual se encontra a raiz viva da sua edificação e o vínculo sacramental do seu existir em plena comunhão com toda a Igreja" (ChL, 26). Nesta perspectiva, paróquia não é apenas uma realidade institucional, burocrática, mas fundamentalmente teológica. Em termos de renovação pastoral e instituicional, ela é então chamada a ser o que ela é, e é dentre desta perspectiva que se encontram os esforços de revitalização paróquia, na tentativa de dar-lhe um rosto mais teológico e menos institucional.

Reveste-se de fundamental importância na busca da identidade da paróquia a expressão coetus christifidelium, 'comunidade de fiéis', 'assembléia de fiéis'. Certamente reside aqui a guinada eclesiológica de que é sujeita a paróquia na perspectiva conciliar. O caráter teológico mais relevante da reflexão teológica das últimas décadas sobre a paróquia está na dimensão comunitária, pois ela é uma 'congregação' de fiéis' (LG 28). Povo é constitutivo desta instituição, juntamente com seu pastor. "A paróquia não é principalmente uma estrutura, um território, um edifício, é a família de Deus, como uma fraternidade animada pelo Espírito de unidade" (CL, 26. Cf. LG, 28).

No decreto Apostolicam Actuositatem, n. 10 lemos: "A paróquia apresenta um exemplo luminoso do apostolado comunitário, congregando num todo as diversas diferenças humanas que encontra e inserindo-as na universalidade da Igreja". Percebe-se que a paróquia está em consonância com a eclesiologia do Concilio que assegura a comum condição de todos os batizados, na qual cada um

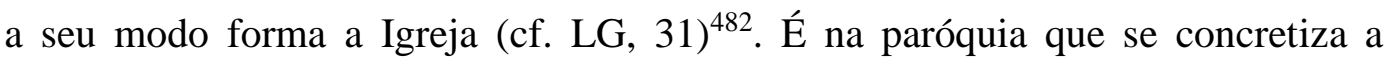
sacerdócio comum de todos os batizados. "A comunidade paroquial - afirma Casiano Floristán - por ser 'povo de Deus' compõe-se de uma diversidade de membros, de carismas e de funções. Em virtude do batismo, todos são irmãos e iguais" ${ }^{\prime 483}$.

${ }^{482}$ Cf. ALMEIDA, J. A. Paróquia, comunidades e pastoral urbana, op. cit., p. 145.

${ }^{483}$ FLORISTÁN, Para compreender a paróquia, op. cit., p. 55. 
As Conferências episcopais latino americanas dão, por sua vez, valiosa contribuição à reflexão teológica da paróquia. Segundo Puebla “a paróquia realiza uma função de Igreja em certo sentido integral, já que acompanha as pessoas e famílias no decorrer de toda a sua existência, na educação e no crescimento da fé" (DP n. 644). Em Santo Domingo, os bispos latino americanos afirmam que "a paróquia, comunhão orgânica e missionária, é assim uma rede de comunidades" (DSD, n. 58). Ressoa aos ouvidos o apelo feito pela V Conferência Episcopal, realizada em Aparecida, SP, quando convoca a Igreja para a conversão pastoral e estrutural. A V Conferencia Episcopal Latino-Americana afirma que paróquia é chamada a ser "casa e escola de comunhão" (DAp, 170). Ao retomar Ecclesia in América, a V Conferência diz que a paróquia é lugar privilegiado onde a maioria faz experiência concreta de Cristo e comunhão eclesial (Ecclesia in América, 41; DAp, 170).

Há de ressaltar também a nova perspectiva canônica da paróquia no Código de 1983. "A paróquia é uma determinada comunidade de fiéis, constituída de modo estável na Igreja particular, cujo cuidado pastoral, sob a autoridade do bispo diocesano, se entrega a um pároco, como pastor próprio" (c. $512 \& 1)^{484}$. Enquanto que o Código de 1917 descrevia a paróquia através de quatro elementos, a saber, um território delimitado, um povo concreto, um tempo particular e um pastor próprio, no atual Código há outra perspectiva: a paróquia representa a Igreja universal, uma parte da Igreja diocesana, uma comunidade de fiéis. Verifica-se, portanto, na paróquia uma mudança de lugar teológico e eclesial a partir do último concílio: do pároco à comunidade ${ }^{485}$, da cura das almas à edificação da Igreja, de centrada em si mesma à abertura missionária ao mundo.

Fato é que os vocabulários comunidades-comunitária serão importante para falar da Igreja em geral e da paróquia em particular nos textos do Concílio e

\footnotetext{
${ }^{484} \mathrm{O}$ novo Código de Direito Canônico consagra às paróquias, párocos e vigários paroquiais, o cap. VI do título III, sec. II, livro II, somando 38 cânones (515-552), ao passo que o Código anterior não falava de paróquias, mas somente de párocos e vigários paróquias, em 28 cânones. $\mathrm{O}$ Cânon 204 descreve os membros dessa comunidade: "são os que, incorporados a Cristo pelo batismo, foram constituídos como povo de Deus, e assim, feitos participantes, a seu modo, do múnus sacerdotal, profético e régio de Cristo, são chamados a exercer, segundo a condição própria de cada um, a missão que Deus confiou a Igreja cumprir no mundo".

485 O Cânon 204 descreve os membros dessa comunidade: "são os que, incorporados a Cristo pelo batismo, foram constituídos como povo de Deus, e assim, feitos participantes, a seu modo, do múnus sacerdotal, profético e régio de Cristo, são chamados a exercer, segundo a condição própria de cada um, a missão que Deus confiou a Igreja cumprir no mundo".
} 
pós-concílio. O Concílio supera uma concepção tridentina de enquadramento de fiéis que predominou por séculos, e esforça-se para fazer da paróquia uma comunidade de irmãos. A relação determinante não quer ser mais a relação pároco-fiéis e sim relação calorosa entre os fiéis que formam comunidade ${ }^{486}$. Enfim, na tentativa de sintetizar a novidade conciliar sobre a paróquia, poderíamos dizer que o Vaticano II realizou teoricamente uma tríplice passagem: do territorial para o comunitário; do princípio único do pároco à variedade de atores; do meramente sacral para a totalidade das dimensões da vida e da missão da Igreja ${ }^{487}$.

\subsection{2}

\section{Paróquia, um conceito simbólico instrumental}

Continuando a reflexão da natureza teológica da paróquia, significativa é a ponderação do teólogo italiano Luca Bressan, para quem a paróquia é um conceito simbólico, instrumental ou operacional, cuja razão de ser não estaria tanto no conteúdo como no tipo de relações que ela consegue instituir. Nesta perspectiva, a paróquia é uma estrutura de significado complexo, simbólica ${ }^{488}$. Sua função irrenunciável é tornar presente de modo oficial a tradição, a memória e a identidade cristãs. É tal identidade que legitima tantas mudanças e diferentes perfis paroquiais assumidas ao longo da história.

Sua missão é fazer acontecer a presença do cristianismo em um espaço determinado, dentro de uma cultura, de escrever num tecido social a presença cristã, uma presença capaz de veicular a imagem do cristianismo e a torná-la significativa e reconhecida. Nas próprias palavras do autor, "a paróquia é, portanto, na sua identidade profunda, o instrumento para a construção da identidade cristã, para a instituição desta identidade dentro de cada cultura (o espaço e o tempo habitado pelos homens) no qual é colocado esta estrutura eclesial" 489 .

Paróquia é um processo de significação em ato, e não um significado já dado, ou enunciado de uma instituição já realizada, por isso não modificável. Com

\footnotetext{
${ }^{486}$ Cf. ROUTHIER, G. A paróquia: suas imagens, seus modelos e suas representações, op. cit. In: A Nova Paróquia. BORRAS, A; ROUTHIER, op. cit., pp. 40-41.

${ }^{487}$ Cf. ALMEIDA, Paróquia, comunidades e pastoral urbana, op. cit., p. 151.

${ }^{488}$ BRESSAN, L. La parrochia oggi, op.cit., p. 104.

${ }^{489}$ Ibid., p. 106.
} 
o conceito de paróquia quer-se exprimir o modo de dar nome àquele movimento ininterrupto de eclesiogenese através da qual a Igreja transmite de geração em geração a fé que professa. Pelo conceito de paróquia quer-se indicar os laços sociais, os sistemas de relação que a tradição cristã suscita em cada cultura. Tratase de uma realidade dinâmica a fim de continuar a missão de anúncio, de modo compreensível a cada momento cultural, da mensagem e deposito da fé de que é portadora $^{490}$.

Paróquia entendida como realidade funcional conserva seu caráter dinâmico, aberta a novas configurações. A Igreja necessita de uma estrutura encarnada na história para transmitir sua mensagem de salvação, introduzir sua memória, suscitar e fazer emergi-la nos espaços sociais na cultura dos homens que a habitam ${ }^{491}$. Daí a inculturação da própria paróquia, as constantes renovações e modificações enquanto instrumento a serviço da fé. Nesta perspectiva, a paróquia tem uma tarefa antropológica e cultural: possibilitar e colocar em comunhão duas culturas, criar relações, trocas e possibilidade de encontros entre mundos antropológicos diferentes: cristianismo e sociedade, suscitando com isso a experiência eclesial ${ }^{492}$. Como instrumento antropológico a paróquia é encarregada de estruturar sistemas de significado novos e diferentes para que a memória cristã seja compreensível a aceita por cada cultura na qual a Igreja está. “A paróquia tem como tarefa primária aquela de estruturar a presença do cristianismo dentro de uma sociedade, assumindo daquela sociedade as linguagens, a cultura, os espaços, as instituições úteis a dizer a novidade cristã ${ }^{\prime 493}$. Reafirma-se, portanto, o que já foi declarado em outro item: não existe paróquia e sim paróquias.

Não há contradição entre tal compreensão simbólico instrumental proposta pelo autor e os elementos da identidade oferecidos pelo Vaticano II. Ao afirmar que paróquia assume um conceito instrumental se está apontando para a necessidade de uma estrutura para a encarnação da fé cristã, o que nos permite uma relativização do institucional na garantia do que é irrenunciável na fé cristã. Dito diferente, a instituição paroquial não é fim em si mesma, mas está a serviço da fé, da iniciação cristã, da experiência comunitária e salvífica. Sua identidade

\footnotetext{
${ }^{490}$ Ibid., p. 109.

${ }^{491}$ Ibid., p. 112.

492 Ibid., p. 114.

493 Ibid., p. 113.
} 
mais profunda está em garantir a 'funcionalidade' comunitária cristã, isto é, promover a experiência salvífica. Em outros termos, sua identidade está justamente naquilo que é sua missão.

O que se pode concluir, através desta rápida abordagem, é que o dilema com que se defronta a paróquia hoje não é teológico, mas pastoral. Teologicamente, vemos um avanço na reflexão paroquial. Quando passamos, porém, da reflexão à pastoral nos esbarramos com barreiras estruturais, cujas respostas nem sempre são tão evidentes.

\section{4}

\section{A pertinência da paróquia na vida da Igreja}

Uma das questões mais intrigantes no tocante ao discurso sobre a paróquia diz respeito ao futuro desta instituição bimilenar. Não é de hoje a afirmação da crise paroquial, como também não são recentes as tentativas de renovação. Há quase um século teólogos e pastoralistas se debruçam sobre o que é hoje um dos maiores desafios eclesiais: repensar e propor novo perfil de comunidade cristã paroquial. É possível um cristianismo sem paróquia? Qual o futuro desta instituição, ou qual a paróquia do futuro? Existe ainda espaço para as paróquias? Os posicionamentos são dos mais opostos, desde a afirmação de paróquia como 'uma comunidade impossível' ${ }^{494}$, como da declaração que diz ser a paróquia 'comunidade de comunidades ${ }^{495}$. Com essas duas citações é possível perceber o árduo terreno dentro do qual nos movemos.

As discussões sobre a paróquia se concentram basicamente em três posicionamentos. Em proporção cada vez menor há quem, ao defender a validade da paróquia, não aceite mudanças por entender que ela vai muito bem. Há os que vislumbram um futuro eclesial sem paróquia ${ }^{496}$. Iniciativas de experiências têm sido vistas aqui e acolá, nas quais a mais expressiva parece ser a Diocese de

\footnotetext{
494 Cf. GAMO, M. La parroquia, comunidad impossible. In: Vida Cristiana y compromisso terrestre. V Semana de Teología de la Universidad de Deusto. Mensajero. Bilbao, 1970, pp. 435498.

${ }^{495}$ CONNAN F. e BARREAU C. La parroquia de mañana. Studium: Madrid, 1970.

${ }^{496}$ Cf. AUBRY, A. Una Iglesia sin parroquias. Siglo XXI: México, 1974. Afirma o autor que a paróquia está a ponto de desaparecer, 'não porque sua vida foi inútil, mas porque sua missão está acabada".
} 
Poitiers, França ${ }^{497}$. Há os que declaram a crise da paróquia, apontam as principais lacunas, ao mesmo tempo em que veem a possibilidade e urgência de sua revitalização ${ }^{498}$. Pode-se afirmar que neste grupo se encontra a grande maioria dos estudiosos no assunto, haja vista tantas tentativas de renovação paroquial no último século. Sem a pretensão de detalhar todas as iniciativas ensaiadas, vale a pena fazer menção às mais significativas. J. C. Périsset, apresenta em sua tese doutoral pela Universidade Gregoriana, em Roma, no ano de 1973, as principais teses sobre a paróquia nos últimos anos: paróquia como comunidade litúrgica, paróquia como família, paróquia como primeira atuação da Igreja, como célula da diocese, como koinonia, como lugar de ministérios ${ }^{499}$.

O mesmo dilema sobre o futuro da paróquia pode ser percebido entre os fiéis. Há cristãos que apostam na possibilidade comunitária da paróquia, e se esforçam para dar-lhe mais dinamismo. Há os que simplesmente a abandonam, por desejo de uma maior autenticidade de vida comunitária, e não satisfeitos com a paróquia, buscam outras formas de ser Igreja, entre as quais encontra-se o fenômeno das novas comunidades eclesiais ${ }^{500}$.

Para além das opiniões a favor ou contra, o que não é justo é a acusação da falta de esforços e tentativas de renovação da instituição paroquial ao longo da

${ }^{497}$ Cf. o relato desta experiência, em ROUET, A., BOONE, É.; BULTEAU, G.; RUSSEIL JeanPaul; TALBOT, A. Milano: Paoline, 2007. Un nuovo volto di Chiesa: L'esperienza coraggiosa e innovativa della diocesi di Poitiers.

${ }^{498}$ A paróquia 'está doente', 'em crise', 'agonizante', ' em quebra', 'é um grande problema'. Cf. MURGUI, J. M. Parroquia y comunidad en la Iglesia española del posconcilio. Edicep. Valência, 1983.

499 PÉRISSET, J. C. Curé et presbyterium paroissial (Analecta Gregoriana, 227). Roma, 1982, 450p.

${ }^{500}$ Tem chamado a atenção dos teólogos, pastoralistas e sociólogos da religião o fenômeno das assim chamadas 'novas comunidades eclesiais'. Cf. LOPES, E. Católicos reclusos. Revista Veja, abril, 2009, ano 41, n. 48, 3 de dezembro de 2008, pp. 110-116. Embora não sejam de hoje os movimentos e associações de fiéis, é a partir da eclesiologia de comunhão do Vaticano II que eles se expandem consideravelmente. Vejamos a afirmação de João Paulo II. "Nestes tempos mais recentes, o fenômeno da agregação dos leigos entre si assumiu formas de particular variedade e vivacidade. Se na história da Igreja tal fenômeno representou sempre uma linha constante, como o provam até aos nossos dias as várias confrarias, as ordens terceiras e os diversos sodalícios, ele recebeu, todavia, um notável impulso nos tempos modernos que têm visto o nascer e o irradiar de múltiplas formas agregativas: associações, grupos, comunidades, movimentos. Pode falar-se de uma nova era agregativa dos fiéis leigos". ChL, 29. Apesar de constituírem uma realidade bastante recente na Igreja do Brasil (A pioneira é a comunidade Canção Nova, em Cachoeira Paulista, fundada em 1978), já estão presentes do norte ao sul do país, e tudo indica que seu crescimento não pare tão cedo. São no nordeste e centro-oeste as regiões mais férteis para o nascimento e expansão de novas comunidades É difícil saber com maior exatidão o número delas existentes. Por constituírem uma dinâmica laical e não tanto institucional, nem sempre elas são registradas sistematicamente nas paróquias e dioceses, além do que a cada dia surgem novas comunidades. 
história, particularmente nas últimas décadas, ainda que as dificuldades de uma efetiva renovação sejam proporcionais ou superiores aos resultados alcançados. Nosso enfoque, como já enfatizado na introdução da pesquisa, será dialogar a paróquia a partir da iniciação cristã catecumenal, e vice versa, o que em perspectiva de ensaio acadêmico e pastoral, significaria acrescentar na lista acima mencionada, o título 'paróquia catecumanal'.

Apesar da aguda crise paroquial, tal instituição não pode sem mais ser descartada. Conserva ela valores fundamentais enquanto instituição eclesial, que outras formas comunitárias da vivência da fé apresentam dificuldades de expressar. Neste sentido, afirmamos a pertinência da paróquia para a evangelização, desde que lhe seja dada uma nova configuração. Não se pode sem mais descartar uma instituição de dois milênios, sem oferecer à Igreja um modelo substituto. Não obstante sua crise, ela é pertinente ao futuro da Igreja à medida que se coloca em busca de constante renovação. Faz-se necessário simultaneamente a renovação da paróquia e ensaio de novas formas de ser Igreja. Em tempo de pluralismo cultural e religioso, somente a diversidade de formas eclesiais comunitárias responde aos desafios pastorais do momento.

Sua capacidade de resistência em meio há quase um século de declarada crise revela por si só sua importância. Se é verdade que ela apresenta um cansaço, é verídico também que ela é a principal porta de entrada para novos cristãos. Conserva ela um espaço de significado religioso dentro da cultura atual, ainda que em escala infinitamente menor se comparado ao contexto de cristandade.

Sendo a paróquia a organização eclesial mais recorrente na Igreja, ocupa um espaço real e significativo de iniciativas eclesiais, sobretudo por fazer parte da identidade católica cristã, pela respeitável dimensão simbólica de referência para o cristão, e por ser ainda a porta de entrada mais imediata para a maioria dos fiéis ${ }^{501}$.

O valor inquestionável da paróquia está na abertura a todos os fiéis. A paróquia é efetivamente a Igreja para todos, sem exclusivismos. "A paróquia representa a forma típica de pertença eclesial, porque exprime o sentido da Igreja para todo crente" ${ }^{, 502}$. É na paróquia, portanto, onde melhor transparece a dimensão católica universal da Igreja, cujas portas não se fecham a nenhuma classe social,

\footnotetext{
${ }^{501}$ Cf. SORAVITO. L.; BRESSAN, L. Il Rinnovamento della parrocchia, op. cit., p. 19.

${ }^{502}$ BRAMBILIA. La parrocchia del futuro, op. cit., p. 569.
} 
econômica, política ou racial. Nesta perspectiva, conserva a paróquia um caráter essencialmente popular, além de promover uma totalidade harmônica. A territorialidade, tão questionada em tempos de novas relações territoriais assegura a catolicidade real, na qual convivem pessoas de diversos estados, idades, níveis econômicos, culturais, experiências de fé, ou seja, torna a paróquia um lugar aberto a todos ${ }^{503}$. Para Pannet, a paróquia é "a Igreja de portas abertas num lugar fixo" "504. Continua João Paulo II, "a Igreja apresenta verdadeiramente, na paróquia, a maternidade dirigida a todos, sem critérios exclusivos de elite" ${ }^{" 505}$. A heterogeneidade de pessoas, nível cultural político e social é então um valor central da instituição paroquial, que outras instituições religiosas apresentam dificuldades em promover.

Salvaguardando a rica teologia da Igreja local, é por meio da paróquia que a diocese se expressa como tal. João Paulo, na Exortação Apostólica Pastores Gregis, n. 45, assim afirma: "a paróquia é o núcleo fundamental na vida cotidiana da diocese". "As paróquia - segundo a Exortação Apostólica Pós-sinodal Ecclesia in America, 41, posteriormente retomado por Aparecida - são células vivas da Igreja e lugares privilegiados em que a maioria dos fiéis tem uma experiência concreta de Jesus Cristo e da Igreja" (Exortação Apostólica Pós-Sinodal Ecclesia in America, n. 41; DAp, 304).

Enfim, apesar de opiniões mais céticas quanto à instituição paroquial, sua pertinência eclesial não pode sem mais ser desconsiderada. Trata-se de uma instituição que muito tem a oferecer à Igreja na medida em que conseguir recuperar sua identidade comunitária.

\section{5}

\section{Da crise a novas possibilidades: a urgência de renovação paroquial}

A sociologia constantemente recorda que ingenuidade seria imaginar uma organização sem estrutura. Isso vale de modo especial para a organização eclesial. Toda comunidade ou realidade humana necessita de uma estrutura, mínima que seja, para poder externar sua missão, sua identidade, seus padrões de

\footnotetext{
503 HACKMANN, G. L. B. Por uma paróquia como comunidade evangelizadora e missionária. Teocomunicação. Porto Alegre, v. 26, n. 111, março 1996, (pp. 03-15), p. 9.

504 PANNET, R. La paroisse de l'avenir de la paroisse, Fayard: Paris, 1979, p. 135.

505 JOÃO PAULO II. Discurso a los obispos de Lombardia em la visita 'ad limina', op. cit., citado por FLORISTÁN, C. Para compreender a paróquia, op. cit., p 35.
} 
comportamento, etc. Importante que essa não seja fossilizante, nem tão pouco se converta em fim em si mesma, o que significa dizer aberta a evoluções e mudanças necessárias em cada contexto, ainda que os caminhos de tais transformações não estejam pré-determinados, porque nascem da necessidade, sensibilidade e criatividade. Nesta perspectiva, não se coloca em xeque o valor da instituição paroquial para a missão evangelizadora da Igreja, apesar do cansaço do atual modelo. Trata-se nada menos de uma das mais importantes instituições eclesiais de toda a história da Igreja, contudo, a continuidade de sua relevância dependerá da capacidade de uma nova configuração.

Comungamos da feliz intuição de Borras e Routhier, quando afirmam a necessidade de abandonar resquícios de saudosismos da 'civilização paroquial' e ao mesmo tempo apostar na capacidade de renovação desta instituição: Dizem os autores:

\begin{abstract}
A nossa opinião é clara: não podemos sonhar com uma restauração da cristandade nem com o renascimento da 'civilização paroquial'. Porém, o fim da 'civilização paroquial' não significa o fim do cristianismo nem o fim da paróquia ... Existe ... uma vontade de profunda renovação da paróquia, precisamente devido ao desafio da transmissão do Evangelho na cultura atual ${ }^{506}$.
\end{abstract}

O ponto de partida irrenunciável neste processo é a conviç̧ão de que crise não significa beco sem saída, caos, mas possibilidade de transformação e de nascimento do novo. Nas sábias palavras de Edgar Moram, "metamorfose significa, simultaneamente, manutenção da identidade e transformação fundamental"507. É possibilidade do novo. Em outros termos, a 'crise-tensão' entre a missão de comunicar a Boa Nova e os desafios da nova cultura que atingem todos os níveis, econômico, social, cultural, e não menos radicalmente o religioso, possibilitam o surgimento de uma nova configuração eclesial. A crise traz consigo a semente das possibilidades; novas perspectivas se abrem. Se são muitos os desafios, não menos são as chances, pois positividade e negatividade se misturam, exigindo discernimento, criatividade e coragem. Do choque-crise entre a nova cultura e a percepção do cansaço com a tradicional modelo eclesial

\footnotetext{
${ }^{506}$ BORRAS, A.; ROUTHIER, G. Introdução. In: BORRAS, A.; ROUTHIER, G. A nova paróquia, op. cit., p. 15.

${ }^{507}$ MORIN, E. Rumo ao abismo: ensaio sobre o destino da humanidade. Bertrand Brasil: Rio de Janeiro, 2011, p. 29.
} 
paroquial deve nascer novas possibilidades. Fundamental é perceber a conexão existente entre mudança cultural e necessidade de nova configuração institucional eclesial. Sempre que se impõe uma 'mudança de época' deve surgir necessariamente uma nova configuração eclesial, pois ambos, Igreja e cultura são realidades enraizadas no tempo e no espaço, o que significa que carregam o caráter da mutabilidade e da dinamicidade.

A visita à história da paróquia foi relevante por trazer à lembrança suas mudanças de tempos em tempos. Se mudar é condição de possibilidade para conservar sua missão, o maior problema que a Igreja, como organização, enfrenta é a tentação humana, muito difundida, de canonizar como relacionamento essencial padrões que surgiram para responder às necessidades de uma época, porém não mais correspondem às da época atual ${ }^{508}$. Tão evidente quanto à crise do modelo paroquial é a urgente necessidade de repensá-la a fim de resgatar sua identidade comunitária e missionária, tornando-se 'comunidade de comunidades' (DA 179), uma vez que “o ponto irrenunciável no conceito de paróquia é a estabilidade dos laços comunitários" ${ }^{\circ 09}$.

Não é de hoje que os documentos eclesiais pedem esforços de renovação paroquial $^{510}$. O documento da V Conferência dos bispos latino americanos, em Aparecida, com especial vigor chamou a atenção para a reformulação das estruturas eclesiais. "Nenhuma comunidade deve isentar-se de entrar decididamente, com todas as forças, nos processos constantes de renovação missionária e de abandonar as ultrapassadas estruturas que já não favoreçam a transmissão da fé" (365).

\section{Afirma o mesmo documento que}

A renovação das paróquias no início do terceiro milênio exige a reformulação de suas estruturas, para que seja uma rede de comunidades e grupos, capazes de se articular conseguindo que seus membros se situam realmente discípulos e missionários de Jesus Cristo em comunhão (DAp, 172) .

\footnotetext{
${ }^{508}$ Cf. GREELEY, A. Sociologia e estrutura de Igreja, op. cit. In: Concilium: Revista Internacional de Teologia. Petrópolis, v. 06, fasc. 48, op. cit., p. 963.

${ }^{509}$ AMADO, J. P. Experiência eclesial em mundo urbano ( $2^{\circ}$ parte), op. cit. In: Atualidade Teológica, v. 9, op. cit., p. 200.

510 A Exortação apostólica Pós-Sinodal Christifideli Laici, 26, de João Paulo II afirma: "A comunhão eclesial, embora possua sempre uma dimensão universal, encontra sua expressão mais imediata e visível na paróquia ... É necessário que todos redescubramos, na fé, a verdadeira face da paróquia, ou seja, o próprio mistério da Igreja presente e operante nela".
} 
A partir do Concilio Vaticano II a Igreja entra em estado de revisão e aggiornamento, e sua estrutura eclesial mais importante não pode fugir dessa tarefa. A tarefa de renovação paroquial requer, antes de mais nada, que se repense os pressupostos sobre os quais a ação pastoral paroquial está alicerçada. Daí a insustentabilidade de uma ação evangelizadora missionária cuja principal preocupação está na manutenção comportamental ${ }^{511}$. Reportamo-nos aqui ao princípio 'mudar para conservar', que diz respeito à coragem e ousadia para modificar os pressupostos históricos na garantia daquilo que é teologicamente irrenunciável para a identidade da paróquia. Vale reafirmar que teológico neste caso é a comunidade, a fé, o testemunho cristão, a caridade, ao passo que configuração institucional, costumes, territoriedade e outros são realidades históricas.

Nunca é demais insistir que a razão da necessidade de constantes mudanças e transformações é simples: não há um Evangelho em si, mas em situação. As mudanças socioculturais-religiosas atingem também a Igreja, que não pode ficar presa a modelos do passado que já não mais transmitem a mensagem cristã $\tilde{a}^{512}$. Cientes de que o atual modelo paroquial não é o único ao longo da história, a vida paróquia é chamada a adaptar-se à realidade na qual está inserida e para a qual deve anunciar o Evangelho. Djalma Rodrigues chama a atenção para a urgência de 'reinventar a paróquia', permanecer no que é essencial, perene, sem medo de abrir mão do provisório ${ }^{513}$.

A intuição de Joel Portela é significativa ao apontar para a necessidade de mudanças, atentos ao contexto histórico na qual a Igreja está encarnada:

Ao anúncio do Deus da Revelação, deve corresponder uma experiência de Igreja, a qual, sem perder sua identidade sobrenatural, configura-se em propostas, objetivos, planejamentos e estruturas. Tais configurações, por sua vez, são construídas através de um significativo processo de articulação que considere, de um lado, as verdades fundamentais da Revelação e, de outro, as categorias socioculturais de cada tempo e espaço" 514 .

\footnotetext{
511 Cf. AMADO, J. P. Experiência eclesial em mundo urbano ( $1^{\circ}$ parte), op. cit. In: Atualidade Teológica, v. 8, op. cit., p. 29.

512 Cf. MIRANDA, M. F. A eclesiologia do Documento de Aparecida. In: Revista Eclesiástica Brasileira, fasc. 268, v. 67, outubro/dezembro, 2007, p. 858.

${ }^{513}$ Cf. ANDRADE, D. R. Reiventar a paróquia?, op. cit., p. 15.

${ }^{514}$ AMADO, J. P. Experiência eclesial em mundo urbano (1 ${ }^{\circ}$ parte), op. cit. In: Atualidade Teológica, v. 8, op. cit., p. 25.
} 
A Igreja precisa haurir do seu contexto sociocultural a linguagem adequada para transmitir a fé, bem como encontrar a estrutura concreta para se organizar. A isso chamamos de inculturação da fé e uma fé inculturada. De acordo com Aparecida, "a Igreja não pode prescindir do contexto histórico onde vivem seus membros" (DAp, 367). Na mesma intuição, França Miranda relembra, que a Igreja "não só pode, mas deve se configurar na história conforme os desafios do contexto e do tempo" 515 .

${ }^{515}$ MIRANDA, M. F. A Igreja numa sociedade fragmentada, op. cit., 332p. 


\section{0}

\section{PARÓQUIA E CATECUMENATO}

O quinto e último capítulo da pesquisa tem a missão de colocar em diálogo as duas instituições estudadas nos capítulos anteriores. Trata-se do núcleo da tese, onde catecumenato e paróquia se interpelarão, deixarão se questionar mutuamente, e mais do que isso, um lançará luz ao outro no processo de renovação e/ou consolidação. O catecumenato é, indubitavelmente, uma instituição que muito tem a oferecer ao processo de renovação paroquial, que por sua vez, à medida que esta entra no processo de renovação, torna-se decisivo para uma efetiva prática catecumanal. Em outros termos, pretendemos neste capítulo sondar a dinâmica de complementariedade, da feliz interdependência entre iniciação cristã catecumenal e instituição paroquial, fundamental para o futuro de ambas.

\section{1}

\section{Iniciação cristã catecumenal e instituição paroquial: em busca da unidade de fundo}

Os capítulos precedentes refletiram a iniciação cristã catecumenal e a instituição paroquial. Na reflexão da iniciação cristã insistimos na passagem do paradigma de catequese doutrinal-ensino para o paradigma catecumenal mistagógico. O modelo de catequese doutrinal possui algumas características inconfundíveis: uma classe, um professor, um livro (catecismo), cujo método é de perguntas e respostas. Não é difícil perceber o modelo paroquial correspondente. A este paradigma corresponde o modelo de paróquia denominado cura animarum. "Essa catequese e este dispositivo de iniciação estavam harmoniosamente inseridos em um tipo de paróquia que definimos de cura animarum" $^{\text {"516. Conclui }}$ Luca Bressan: "a catequese se vê como o instrumento mais adequado para

\footnotetext{
516 BIEMMI, E. Catequesi e iniziazione Cristiana. Uma sfida complessa. In: La rivista del clero italiano. Mensile di aggiornamento pastorale e cultura religiosa dell'Università Cattolica. Anno XCIII, gennaio 2012, p. 71.
} 
concretizar a 'cura animorum' que se converte em objetivo específico e declarado desta instituição" 517 .

Fato é que o fim da civilização paroquial acompanha o fim de um modelo de iniciação doutrinal e conceitual, ainda que em muitos ambientes insiste-se em mantê-lo. Coincidem, portanto, esgotamento do paradigma catequético tradicional e cansaço do modelo paroquial tradicional de que dispomos. O que é causa e o que é consequência são de difíceis respostas. Neste particular, curioso ou evidente é o fato do nascimento paroquial, no século IV, ser simultâneo à decadência catecumenal da Igreja primitiva. Dito diferente, o fim do catecumenato e início do 'catecumenato social' coincidem com o surgimento da instituição paroquial, quando se deu a expansão maciça do cristianismo com a liberdade religiosa dada pelo Edito de Milão, 313, e a oficialização com Teodósio 380 e, posteriormente, o batismo de criança generalizado. A iniciação cristã e o próprio cristianismo tornaram-se, então, uma realidade social, e a comunidade de fé já não era mais o fator decisivo para a iniciação cristã. Isto significa que a paróquia parece ter sido criada num contexto não adverso à fé cristã, mas ao contrário, seu nascimento se deu quando a sociedade já se encontrava num processo de cristianização, o que nos autoriza a questionar a pertinência deste modelo de paróquia seja para a transmissão da fé seja para o sustento da mesma.

A assim chamada 'crise de chegada' sacramental nos obriga a perguntar se o atual 'modelo' paroquial é iniciático, ou se, ao contrário, contribui para o abandono religioso, descrito nas expressões 'sacramento de conclusão', 'sacramento do adeus ${ }^{518}$. Que rosto de comunidade paroquial faz-se necessário para a transmissão da fé em uma cultura na qual cresce a tendência de crença sem pertença, de 'adesões light', cujas comunidades 'precisam' estar mais em função do individualismo religioso do que de uma proposta eclesial comunitária?

Importa perceber, portanto, uma unidade de fundo entre catequese tradicional e o modelo de paróquia estratificado ao longo da história. Interessa-

\footnotetext{
517 BRESSAN, L. Parroquia y catequesis. In: Sinite. Revista de Pedagogía Religiosa. Madrid: Lasalle, vol. LIII, n. 159-160, enero-agosto 2012, p. 224.

518 "De fato, a prática sacramental e catequética hoje em uso constitui para muitos o final de toda expressão religiosa, convertendo-se assim o processo de 'iniciação' em processo de 'conclusão'. Não é sem razão que às vezes se chama a confirmação de 'sacramento do adeus', ou o 'ultimo sacramento"'. ALBERICH, E. A catequese no contexto do Concílio Vaticano II e pós-concílio. In: Revista de Catequese. São Paulo: Unisal n. 61, jan/março, 1993 (pp. 15-26).
} 
nos, contudo, na pesquisa a pergunta pela outra unidade de fundo: o novo paradigma de transmissão de fé, cuja visualização maior está no catecumenato, e a busca de renovação paroquial. Interessa-nos a necessidade de estabelecer um diálogo profundo e sincero entre as duas instituições em questão.

Postas tais perguntas provocativas, queremos afirmar uma conexão, uma unidade de fundo entre iniciação cristã catecumenal e paróquia. Pode-se e deve-se falar em compromisso paroquial com a iniciação à vida cristã. A paróquia é ordinariamente o lugar da iniciação na fé. Constitui esta uma de suas tarefas principais. Apesar de seu cansaço institucional, a paróquia continua sendo a principal porta de entrada de entrada 1 para a maioria dos novos fiéis, o que revela ter um compromisso efetivo com a iniciação cristã dos novos membros. Trata-se da função maternal da Igreja, atestado pelo documento de Aparecida. "A paróquia precisa ser lugar onde se assegure a iniciação cristã” (DAp, 293). Ao mesmo tempo "a instituição catecumenal incrementa assim, na Igreja, a consciência da sua maternidade espiritual" (DNC, 49). Em outras palavras, a existência do catecumenato, por si mesmo, recorda constantemente à paróquia seu compromisso com a iniciação cristã e com a transmissão da fé. "A comunidade cristã só é, de fato, germe e matriz de iniciação quando está em estado de missão e em contínua referência catecumenal" ${ }^{\prime \prime 19}$.

A paróquia não somente tem um compromisso inadiável com a iniciação cristã, como depende fundamentalmente desta tarefa, pois nenhuma comunidade se basta a sim mesma. Comunidades fechadas contradizem a proposta de Jesus, que convocava continuamente pessoas para formarem comunidade. Neste sentido, do ponto de vista teológico, o cuidado da paróquia com a iniciação cristã situa-se no campo de sua identidade-vocação, enquanto que sociologicamente, a perpetuação da instituição depende do ingresso contínuo e permanente de novos membros naquela instituição. Trata-se da possibilidade mesma de sua continuação, enquanto instituição.

\section{1 .2}

Relação dialética: renovação paroquial e efetiva prática catecumanal

\footnotetext{
${ }^{519}$ FLORISTÁN, C. Catecumenato: história e pastoral da iniciação, op. cit., p. 32.
} 
As afirmações acima mostram tratar-se de uma relação por demais próxima entre renovação da paróquia e efetiva prática da iniciação cristã catecumenal. Um passo além, agora, nos permite afirmar que reside ente as duas realidades, mais do que aproximação ou unidade de fundo, uma interdependência quanto ao futuro de ambas. Mais do que aproximação entre a paróquia e iniciação cristã catecumenal, trata-se de uma relação dialética e complementar, na qual o fortalecimento de uma incide, e ao mesmo tempo reclama a vitalidade da outra. Tal dinâmica se assemelha a imagem de uma engrenagem com rodas dentadas. Quando um gira, as outras necessariamente se movimentam; o movimento de uma impulsiona o movimento das demais ${ }^{520}$. "Se não muda a Igreja, não muda a catequese e vice-versa. Somente uma catequese com adultos pode ajudar a fazer nascer uma Igreja adulta" ${ }^{, 521}$.

$\mathrm{O}$ presente e o futuro do catecumenato dependem de um novo rosto do tecido comunitário e estrutural paroquial. A proposta catecumenal, por não ser uma peça isolada no conjunto pastoral, depende efetivamente da qualidade da comunidade eclesial, tanto é verdade que um dos motivos da difícil implantação do catecumenato se deve, em parte, à configuração paroquial que nem sempre contribui para isso. Um novo perfil paroquial é condição necessária para que o projeto de iniciação catecumenal seja levado a cabo e que seus elementos pedagógicos e metodológicos não fiquem arquivados nas páginas do Ritual de Iniciação Cristã de Adultos. Onde estão, contudo, tais comunidades dinâmicas e renovadas? Esta é igualmente a indagação de Boróbio $^{522}$ ? Não se pode cair no círculo vicioso, conforme adverte o mesmo autor. A inexistência de comunidades ideais não pode paralizar o esforço do projeto catecumenal, nem o contrário, 'porque não há comunidades, não há catecumenato, e porque não há catecumenato, não chegamos a comunidades"523. Chegamos, assim, na fundamentação da dinâmica dialética, por nós proposta, entre catecumenato e

${ }^{520}$ ARQUIDIOCESE DO RIO DE JANEIRO. $11^{\circ}$ Plano de pastoral de conjunto. O Rio de Janeiro em missão. Arquidiocese do Rio de Janeiro 2012-2016. Rio de Janeiro: Editora Nossa Senhora da Paz, 2011, p. 10.

${ }^{521}$ RIBAS, L. F. O. Desafios da catequese com adultos: reflexões teológicas sobre formação de catequistas para adultos. In: Revista catequese. São Paulo: Unisal, ano 29, n. 114, abril/junho 2006 (pp. 14-27).

${ }^{522}$ BOROBIO, B. La Iniciation Cristiana: bautismo, educacion familiar, primera eucaristia, catecumenado, confirmacion, comunnidade Cristiana. Salamanca: Ediciones Sigueme, 1996, p. 549.

${ }^{523}$ Ibid., p. 549. 
paróquia. A 'solução' não está em procurar comunidades paroquiais ideais para a implantação catecumenal, nem implantar o catecumenato para daí esperar a conversão pastoral e estrutural da paróquia, mas perceber a dialética do processo ao 'construir' juntos, numa caminhada de mãos dadas, um projeto pastoral e estruturas eclesiais adultas.

O caminho a ser percorrido é de mão dupla. Resgate catecumenal e revitalização paroquial se realizam simultaneamente. $\mathrm{O}$ investimento no catecumenato, a entrada de novos catecúmenos na comunidade, modifica a vida da comunidade e a enriquece; e à medida que ela se revitaliza, torna-se sempre mais propensa ao catecumenato, torna-se também catecumenal e mistagógica. Recorda Aparecida que "uma comunidade que assume a iniciação cristã renova a sua vida comunitária e desperta seu caráter missionário" (Dap, 291). A iniciação à vida cristã catecumenal será tanto mais efetiva à medida que houver uma reconfiguração eclesial adequada, do mesmo modo que uma iniciação catecumenal com qualidade, na riqueza de seus elementos pedagógicos, litúrgicos e pastorais, lançará luzes para o institucional repensar sua configuração. O catecumenato implantado será promotor de mudanças estruturais, por lançar luzes a uma nova paróquia, assim como o catecumenato não é algo já dado, consolidado, mas a ser construído, pois o Ritual por si não garante a eficácia catecumenal. Se um novo perfil de comunidade paroquial é essencial para a iniciação cristã catecumenal, esta por sua vez é fonte de revitalização paroquial porque sua pedagogia mistagógica lança luzes para repensar dimensões essenciais da vida paroquial.

A dinâmica catecumenal tem muito a contribuir para a revitalização paroquial. Em tempos de pluralismo cultural e religioso, a proposta de iniciação cristã catecumenal pode ser um referencial pastoral não somente para a evangelização dos que vão à procura dos sacramentos mas sobretudo uma fonte de iluminação para reiniciar na fé os já batizados afastados ou não iniciados, para repensar os métodos pastorais, enfim, na busca de uma reconfiguração eclesial e pastoral. Neste sentido, ensaiamos atribuir o adjetivo catecumenal à paróquia, à medida que ela permitir ser iluminada pelos elementos da pedagogia mistagógica catecumenal, à medida que ela ajuda na consolidação catecumenal, enfim, à media que ela se torna também catecumenal, mistagógica. Do mesmo modo que nos é 
permitido falar de catequese com inspiração catecumenal (DNC 45), torna-se possível falar de paróquia com inspiração catecumenal.

\section{2}

Do primeiro anúncio a uma estrutura paroquial missionária: interpelações mútuas entre pré-catecumenato e a missionariedade paroquial

Daremos início, assim, ao ‘jogo dialético’ entre paróquia e catecumenato, a começar pela primeira etapa do processo catecumenal, a saber, o précatecumenato. Em termos pastorais, ao pré-catecumenato equivale à dimensão missionária da paróquia, em cujo diálogo ambos, missionariedade paroquial e précatecumenato se iluminarão mutuamente. Sondar o que a primeira etapa do itinerário catecumenal diz ao processo de renovação paroquial, e esta àquela, é o que se propõem as páginas a seguir.

Já mencionamos no capítulo anterior que o tempo do pré-catecumenato é por excelência o tempo da 'primeira evangelização' (RICA, 7), do anúncio de Jesus Cristo, ou numa linguagem mais próxima aos primórdios do cristianismo, do anúncio kerigmático. O despertar da fé, suscitar o desejo eclesial, lançar as sementes de uma progressiva conversão são algumas das metas almejadas neste período. Noutras palavras, trata-se de apresentar e reapresentar a Pessoa de Jesus Cristo e sua proposta de vida, ou na linguagem da Conferência de Aparecida, recomeçar a partir de Jesus Cristo (DAp, 41). Portanto, pré-catecumenato e missão são equivalentes no tocante ao espírito que motiva ambas as atividades.

Quando apresentávamos a metodologia e chamávamos a atenção para algumas características do processo catecumenal resgatado pelo Vaticano II, nos seus vários tempos e etapas, afirmávamos que da seriedade e empenho do primeiro tempo, denominado pré-catecumenato, dependeria o resultado de todo o itinerário da iniciação. Reafirmamos agora tal convicção voltados à instituição paroquial: do assumir a dinâmica e o espírito pré-catecumenal no conjunto pastoral paroquial dependerá a revitalização da paróquia. Se pré-catecumenato é a etapa que remete à dimensão essencialmente missionária do processo da iniciação cristã catecumenal, quando o assunto é a renovação paroquial, parece não haver outro caminho mais urgente do que começar pelo mesmo ardor missionário. Com 
palavras mais claras, o espírito pré-catecumenal abre caminhos pastorais e acadêmicos para repensar a missionariedade paroquial.

Como dar à paróquia um rosto mais missionário e menos institucional? E ao mesmo tempo, como fazer da iniciação cristã catecumenal uma real prática missionária que, mais do que conferir sacramentos, gere discípulos missionários? Mais do que oferecer uma resposta cabal, nossa intenção é mostrar que os objetivos pré-catecumenais apresentados pelo RICA estimulam a instituição paroquial a tornar-se, em seu conjunto de atividades e estruturas, também précatecumenal, ou seja, missionária, anunciadora do kerigma, despertadora da fé, casa acolhedora de todos. Por outro lado, à medida que o conjunto das atividades paroquiais adentrarem no movimento e espírito do primeiro anúncio querigmático muitas serão as vantagens para os objetivos e metas da etapa pré-catecumenal. A título de exemplo, tomemos o ministério do introdutor: esse ministério não será algo excepcional, mas extensão ou visibilidade de uma Igreja toda acolhedora; à media que a paróquia assumir a dinâmica pré-catecumenal não será difícil novos introdutores.

O contraste, onde de um lado parece ser o pré-catecumenato o período mais importante do processo da iniciação, e de outro é aquele que menos acontece na realidade, não se deve ao fato da paróquia, no seu conjunto de atividades e estruturas, carecer da dinâmica mistagógica? Recorda-nos Floristán que "só uma Igreja que inicia é capaz de receber novos fiéis iniciados"524, o que significa que atribuir as tarefas específicas do tempo pré-catecumenal tão somente aos 'introdutores' seria o mesmo que decretar a falência da instituição catecumenal, cuja restauração está dando seus primeiros passos, apesar de remeter ao último Concílio ecumênico. À medida que a paróquia assume a dinâmica précatecumenal em tudo o que ela realiza, então a etapa pré-catecumenal e o ministério do introdutor alcançarão os resultados a que se propõem. A renovação paroquial está convocada a ultrapassar a realização de atividades précatecumenais previstas pelo RICA, para tornar-se ela mesma pré-catecumenal, assumindo um compromisso efetivo com o primeiro anúncio, com o contato pessoal, com a acolhida e acompanhamento, sobretudo no mundo dos adultos, ainda que já sejam 'iniciados' na fé. Categorias como encontro, saída, convite,

\footnotetext{
${ }^{524}$ FLORISTÁN, C. Catecumenato, op. cit. p 31.
} 
anúncio devem fazer parte permanentemente da agenda paroquial, o que significa que o pré-catecumenato, ou o tempo da primeira evangelização, proposta com vigorosa atualidade, seja assumido num contexto maior do que aquele das atividades da catequese, dos catequistas e introdutores. Se a iniciação cristã hoje é prioridade maior do conjunto das atividades eclesiais, inconcebível que a paróquia seja para muitos tão somente um lugar de prestação de serviços religiosos, ou que a iniciação cristã seja meramente mais uma das atividades lá realizadas. Urge a passagem de uma paróquia que realiza iniciação cristã para uma paróquia que seja toda ela iniciática, ou se preferimos, catecumenal, mistagógica, adulta ${ }^{525}$.

\subsection{1}

\section{A missionariedade paroquial à luz da dinâmica pré-catecumenal}

A temática da missão tem estado presente na agenda eclesial nas últimas décadas, e o que é mais significativo, com uma nova compreensão eclesiológica, agora em diálogo com o mundo e com a cultura, deixando definitivamente para traz aquela postura tão característica, e com cores ainda mais fortes na idade moderna, de aversão e combate à realidade temporal ${ }^{526}$.

A Igreja 'existe para evangelizar', recorda Evangelii Nuntiandi. Desde os primórdios do cristianismo a comunicação do Evangelho constitui a razão de ser da Igreja, sua mais profunda missão. "Evangelizar constitui, de fato, a graça e a vocação própria da Igreja, a sua mais profunda identidade" (EM, 13). Comunicar e possibilitar aquela experiência originária e salvífica dos discípulos com o Ressuscitado às gerações futuras é a mais nobre vocação da Igreja.

\footnotetext{
${ }^{525}$ A observação de Boróbio é iluminadora para nossa pesquisa: "O adjetivo 'catecumenal' tem sido nos últimos anos um símbolo de busca de renovação e autenticidade cristã (...) As mesmas comunidades ou grupos recebem com freqüência o qualificativo de 'catecumenais'. Sem nos determos a valorar o uso ou abuso do termo em cada caso, cabe assinalar as razões e intenções que motivam seu emprego". BORÓBIO, D. La iniciation cristiana, op. cit., p. 536.

${ }^{526}$ Esse é o grande anseio de João XXIII ao convocar o Concílio Vaticano II. Por ser um Concílio eminentemente pastoral, dois são os eixos centrais: o eixo ad intra, isto é, a natureza da Igreja, e o segundo ad extra, a missão da Igreja em diálogo com a cultura. Nas palavras de França Miranda, "devemos afirmar mais corretamente que a função última da Igreja, enquanto Povo de Deus e comunidade dos cristãos, é levar outras gerações a realizarem as experiências salvíficas que deram sentido e unidade á existência de seus membros. Ela transmite não só enunciados ou doutrinas, mas sobretudo experiências salvíficas, resultantes do encontro com Jesus Cristo vivo". MIRANDA, M. F. A salvação de Jesus Cristo: a doutrina da graça. São Paulo: Loyola, 2004, p.16.
} 
Igreja, hierarquia, ordens religiosas, movimentos, estruturas, pastorais, paróquias somente se justificam quando estão a serviço da missão, e perdem sua identidade quando tendem a se tornarem fins em si mesmas. Foi esta a grande intuição do aggiornamento do Vaticano II, ao tomar consciência de que o Reino é maior que a Igreja.

Sem ser privilégio exclusivo da paróquia, é a ela que cabe a tarefa primeira de transformar-se em estrutura missionária e evangelizadora, possibilitadora desta experiência salvífica e comunitária. Se em inúmeros documentos a Igreja chama a atenção para a urgência missionária, a Conferência de Aparecida o faz com insistência. $\mathrm{O}$ documento fala expressamente de 'renovação missionária das paróquias' (DAp, 173) e que "nenhuma comunidade deve se isentar de entrar decididamente, com todas suas forças, nos processos constantes de renovação missionária, de abandonar as ultrapassadas estruturas que já não favorecem a transmissão da fé" (DAp, 365). Mais do que em outras épocas, "necessitamos que cada comunidade cristã se transforme num poderoso centro de irradiação da vida em Cristo" (DAp, 362).

Posto isto, não podemos deixar de nos perguntar pelo real estado missionário da paróquia. As análises mostram uma crise em sua identidadevocação missionária.

Do doméstico ao institucional; da casa para o templo; da simplicidade ao poder; de anunciadora do Reino para anunciadora de si mesma. Cresceu em número, perdeu em qualidade. Estendeu-se pelos séculos e chegou ao século XXI em crise de identidade missionária ${ }^{527}$.

A postura paroquial de auto-suficiência, fechada em si mesma, em relação à sociedade e seu conjunto de relações gerou um zelo excessivo aos que então 'dentro' da paróquia, ou seja, os 'já iniciados' esquecendo-se dos que dela não

527 MIKUSZKA, G. L. Por uma paróquia missionária à luz de Aparecida. São Paulo: Paulus, 2012, p. 14. Confira nesta obra um excelente resumo histórico da missão na história da Igreja, fundamentado em abundante bibliografia. $\mathrm{O}$ autor chama a atenção às mutações do período missionário primitivo (séculos I-II) da Igreja das casas, missão e martírio, e as primeiras transformações no período pos apostólico, e posteriormente missão e império. O autor chama a atenção que o eixo central da missão era a comunidade. A importância da comunidade na ação missionária, e posteriormente, o fio condutor foi a instituição, e a autoridade eclesial. "Sob as graças do poder de Constantino, que defendia a fé cristã para o mundo inteiro, as pequenas comunidades domésticas originárias passaram a ser multidão, numa missão imperial que buscava administrar, organizar e fortalecer a Igreja, mais do que conservar pessoas para formar comunidades'. Ibid., p. 27. 
fazem parte $^{528}$. Excessivamente voltada para si, preocupada com a administração dos sacramentos, a paróquia assimilou uma postura estática, na espera dos que dela se aproximam. "Com os seus edifícios bem assentes e solidamente edificados, a Igreja dá muitas vezes a impressão de estar imóvel, ao passo que aquilo que está na moda é a mobilidade e não se comprometer senão por um curto espaço de tempo" 529 .

As palavras de Comblin, se carregadas de uma dose de pessimismo, não deixam de ser provocativas.

\begin{abstract}
A Igreja mantém nas cidades a estrutura obsoleta da paróquia. O clero está sendo preparado para atuar dentro do quadro paroquial ... Ora, estruturalmente, a paróquia é feita para conservar, ajudar, promover os que participam do culto, as pessoas que pertencem à pequena minoria dos que já estão no tempo... A paróquia não assume as fábricas nem os supermercados, nem as escolas, nem os colégios, nem as universidades, nem os hospitais, as instituições esportivas, culturais, de diversão, nem os meios de comunicação da cidade. Ela está organizada ao redor dos sacramentos e das festas litúrgicas. Nem sequer consegue organizar a catequese dos adultos, menos ainda sua formação missionária. A igreja está claramente a serviço de si própria. Não se pode negar as excelentes intenções de muitos párocos, toda a imaginação para fazer uma paróquia missionária. O problema é estrutural" ${ }^{\prime \prime} 30$.
\end{abstract}

Uma porção significativa de pessoas não é atingida pela ação evangelizadora da paróquia tradicional. Certos espaços geográficos e ambientais são esquecidos quase que por completo por ela, além de que o número dos que chegam às paróquias para a celebração dominical é limitado (DAp, 173). Sua estrutura eclesial, sem desconsiderar toda a boa vontade de inúmeros missionários, sejam leigos ou ordenados, está organizada em torno da idéia de 'segurança': segurança para o padre que tem na paróquia um meio de sobrevivência; segurança para os fiéis que tem um lugar onde cumprir suas obrigações religiosas. Acrescenta a isso a escassez do clero num contexto de inchaço populacional das cidades e suas periferias, com paróquias excessivamente grandes. Além de serem poucos os padres para o trabalho evangelizador, não

\footnotetext{
${ }^{528}$ SORAVITO, L.; BRESSAN L. Il Rinnovamento della parrocchia in una società che cambia, op. cit., p. 101.

${ }^{529}$ ROUTHIER, G. Reajustamentos pastorais à medida dos actuais desafios, op. cit. In: BORRAS, A.; ROUTHIER, G. A nova paróquia, op. cit., pp. 198-199.

${ }^{530}$ COMBLIN, J. As grandes incertezas da Igreja atual. In: Revista Eclesiástica Brasileira. Petrópolis: Vozes, v.67, fasc. 265, jan/mar 2007, p. 41.
} 
poucos não conseguem descentralizar-se para um trabalho em equipe, perdendo assim a oportunidade de contarem com o protagonismo e a criatividade dos leigos.

É possível então falar de missionariedade paroquial, sem que com isso se entenda mais uma pastoral ao lado das outras $?^{531}$ Da resposta a esta pergunta depende a possibilidade de renovação paroquial. Se respondermos não, então a 'manutenção pastoral' conservará sua persistência. Se a resposta for sim, aí então se faz necessário antes uma conversão de mentalidade. A esta missionariedade paroquial o papa Francisco denominou de dimensão paradigmática da missão, que “implica colocar em chave missionária a atividade habitual das Igrejas particulares"532.

A quinta Conferência Episcopal Latino americano e Caribenha aposta na missão como condição imprescindível para a renovação da Igreja em geral e da paróquia em particular. A missão é o eixo norteador do Documento, haja vista seu título 'discípulos missionários'. O mesmo documento deixa transparecer sua preocupação com a instituição paroquial, sempre em perspectiva missionária, no qual dos 553 números o termo paróquia aparece em 39 deles ${ }^{533}$. Aparecida utiliza expressões contundentes e de certa forma inovadoras em relação a documentos antecessores no tocante à missão. Queremos chamar a atenção para quatro delas, todas interdependentes: 'renovação missionária das paróquias' (DAp, 173),

\footnotetext{
${ }^{531}$ Stefano Raschietti faz um excelente retrospecto da expressão 'pastoral missionária'. Segundo o autor, em nenhum documento das Conferências Episcopais Latino-americanas fala-se de 'pastoral missionária', exceto uma vez na Mensagem final de Santo Domingo: "a Nova Evangelização intensificará uma pastoral missionária em todas as nossas Igrejas e far-nos-á sentir responsáveis por transpor as nossas fronteiras a fim de levar a outros povos a fé que há 500 anos chegou até nós" (Mensagem Final do DSD, 33).Também nos documentos do Vaticano II não se cita a expressão 'pastoral missionária', a não ser uma única vez em Ad Gentes. Nos documentos missionários do magistério pontifício ela somente aparece duas vezes, na Redemptoris Missio (RMi, 65; 75), ao falar dos 'agentes' da 'pastoral missionária'. Nestas duas passagens, é impreciso o significado do termo 'pastoral missionária', entendendo por ele animação missionária, formação, e cooperação missionária. Em Aparecida, embora seja a única vez que aparece a 'pastoral decididamente missionária' (DAp, 70), consagrou-se a expressão e está paulatinamente mobilizando as paróquias. Cf. RASCHIETTI, S. A pastoral missionária a partir da comunidade local, op. cit., p. 1.

531 Voltaremos a este assunto posteriormente ao abordarmos a formação dos missionários, sobretudo a formação dos catequistas.

${ }^{532}$ PAPA FRANCISCO. Discurso aos dirigentes do CELAM. O papa fala das duas dimensões da missão, a paradigmática e a programática. "A Missão Continental está projetada em duas dimensões: programática e paradigmática. A missão programática, como o próprio nome indica, consiste na realização de atos de índole missionária. A missão paradigmática, por sua vez, implica colocar em chave missionária a atividade habitual das Igrejas particulares".

${ }^{533}$ Cf. PEREIRA, J. C. Paróquia missionária á luz do documento de Aparecida. Procedimentos fundamentais. Ed. CNBB, 2012, p. 9.
} 
'pastoral decididamente missionária' (DAp, 370) ${ }^{534}$, 'permanente conversão pastoral' (DAp, 366) ${ }^{535}$, 'estado permanente de missão' ${ }^{536}$.

Importa perceber que a renovação paroquial passa necessariamente pela conversão missionária. Não estamos nos referindo tão somente à implantação catecumenal nas paróquias, cuja metodologia é a expressão mais clara de uma pastoral decididamente missionária. Trata-se de uma dimensão transversal a perpassar o todo da paróquia. "Impõe-se uma conversão radical da mentalidade para nos tornarmos missionários - e isto vale tanto para os indivíduos como para as comunidades" (RMi, 49). Missionariedade diz respeito à conversão de mentalidade, de metodologia, de propostas pedagógicas, trabalho de conjunto, trabalho orgânico, novas estruturas etc. Trata-se do desejo de redescobrir o frescor da essência da missionariedade em tudo o que a paróquia realiza, desde o anúncio, a caridade, o testemunho, a formação, e não menos importante, a sua estrutura. Portanto, por paróquia missionária não se entende meramente atividades realizadas nela e por ela, muito embora os projetos missionários sejam decisivos, além de visualizarem o rosto de uma Igreja em permanente estado de missão. Entretanto, para que o 'permanente' não seja esporádico, missão quer ser um paradigma por excelência que envolve todo o corpo eclesial. Equívoco pastoral consistiria em se contentar com meros projetos e campanhas missionárias, esporádicas e pontuais, como é comum em muita realidades paroquiais, através de semanas ou de mês missionários, o que é igualmente válido mas não suficiente. Atividades missionárias só terão sentido quando despidas da surrada roupagem de 'manutenção pastoral', inclusive o catecumenato, que por vezes, conforme já lembrado, somente recebe o nome de catecumenato. Não basta um decreto de restauração para que ele seja missionário e iniciático. Se não for assumido com o espírito missionário que é próprio de sua metodologia, receberá somente o nome

\footnotetext{
534 “A conversão pastoral de nossas comunidades exige que se vá além de uma pastoral de mera conservação para uma pastoral decididamente missionária" (DAp, 370).

535 "Os bispos, presbíteros, diáconos permanentes, consagrados e consagradas, leigos e leigas, são chamados a assumir atitude de permanente conversão pastoral, que implique escutar com atenção e discernir 'o que o Espírito está dizendo às Igrejas' (Ap 2, 29), através dos sinais dos tempos em que Deus se manifesta" (DAp, 366).

536 ‘... Procurará colocar a Igreja em estado permanente de missão. Levemos nossos navios mar adentro, com o poderoso sopro do Espírito Santo, sem medo das tormentas, seguros de que a Providência de Deus nos proporcionará grandes surpresas" (DAp, 551).
} 
de catecumenato, mas na realidade será guiado pela mentalidade de catequese tradicional $^{537}$.

Esta firme decisão missionária, portanto, deve impregnar todas as estruturas eclesiais e todos os planos pastorais de dioceses, paróquias, comunidades religiosas, movimentos, enfim, todas as instituições da Igreja (DAp, 365-366). A razão principal do 'estado permanente de missão' já foi por demais lembrado nesta pesquisa: em linguagem sintética, pode-se ser assim recordado: fim da 'civilização paroquial' e fim 'do catecumenato social'.

\section{2 .2}

\section{Otimizar na paróquias as oportunidades já existentes para o primeiro e segundo anúncios}

Em continuidade com a reflexão da missionariedade à luz do précatecumenato, torna-se oportuno uma palavra sobre o primeiro anúncio e segundo anúncios $^{538}$. $\mathrm{O}$ anúncio é parte constituinte de uma comunidade de fé. Comunicar o Evangelho é questão crucial para a paróquia. Muito mais do que noutros tempos, sem desconsiderar o alimentar na fé os já iniciados, e isso significa formação permanente, o compromisso fundamental da paróquia na atualidade é voltar-se para a transmissão da fé, haja vista o crescimento da indiferença religiosa. Nesta perspectiva, em consonância com a pedagogia do RICA, a Conferência de Aparecida dá um destaque à urgência do primeiro anúncio, que comece pelo kerigma e que leve ao encontro pessoal com o Senhor (DAp, 289).

No itinerário catecumenal fala-se com propriedade de primeiro anúncio. Trata-se de uma das marcas da dinâmica catecumenal, sobretudo do tempo précatecumenal. Motivados por este espírito e atentos às necessidades pastorais, devemos falar de segundo anúncio, ou reanúncio, que consiste na ação pastoral aos afastados, indiferentes, machucados com a comunidade eclesial, os que vivem uma fé de costume, uma fé sociológica, ou que se contentam com alguns ritos. A estes se deve dirigir preferencialmente a atenção paroquial. Somente a partir desta atenção, desta prioridade se pode falar genuinamente de catecumenato. Ou seja, o catecumenato, ainda que ilumine todas as ações eclesiais, não é para os já

\footnotetext{
537 Voltaremos a este assunto posteriormente ao abordarmos a formação dos missionários, sobretudo a formação dos catequistas.
} 
iniciados. Chegar aos afastados para então propor a caminhada da iniciação, e não esperar que eles se aproximem é o primeiro passo da realização do catecumenato, o que não será possível sem uma paróquia missionária.

Das quatro etapas do catecumenato é, sem dúvida, a primeira a que mais interpela a paróquia na atual mudança cultural. Diante do perigo da terceirização do despertar da fé tão somente ao catecumenato, o Diretório Geral para a Catequese destaca que "o fato de que a catequese, em um primeiro momento, assuma essas tarefas missionárias, não dispensa a uma Igreja particular de promover uma intervenção institucionalizada do primeiro anúncio, como a atuação mais direta do mandato missionário de Jesus" (DGC 62)'. A instituição de ministros (introdutores) e pastoral específica (catecumenato) para tais funções tem sua razão de ser, enquanto primeiros responsáveis pelo processo, além de uma visualização pastoral de uma Igreja transmissora da fé. Se a linguagem metafórica ajuda a melhor intuir a inter-relação entre pré-catecumenato e paróquia missionária, pode-se afirmar que o catecumenato, em sua etapa pré-catecumenal, seria o trem que carrega consigo outros vagões num movimento articulado e orgânico que caminham na mesma direção e empenhados no mesmo objetivo do anúncio de Jesus Cristo. A estrutura pastoral paroquial é chamada a ter um vigoroso catecumenato como carro chefe da transmissão da fé, o que a torna injustificável hoje sua inexistência em muitas paróquias e dioceses. Tão problemático quanto a não existência do catecumenato na atualidade, é, nos lugares em que ele existe, considerar a transmissão da fé tão somente sob sua responsabilidade. Trata-se de um movimento de impulso mútuo, o que não acontecerá sem um trabalho orgânico e uma pastoral de conjunto. Percebe-se tratar-se de uma guinada pastoral paroquial, acostumada a gastar, em função da própria dinâmica estrutural, a maior parte de seu tempo e energias com os que dela participam. Uma oportuna imagem pode ser a da paróquia como um útero, tendo como responsável primeiro pelo nascimento e desenvolvimento dos filhos, o catecumenato, mas que, no entanto, sabe que no processo de gestação precisa da participação e envolvimento de um número muito maior de pessoas.

Pergunta fundamental no processo de renovação paroquial é pelas chances e potencialidade que paróquia dispõe para anunciar e reanunciar o mistério cristão. Otimizar as iniciativas já existentes de primeiro anúncio, de 
potencialidade missionárias e kerigmáticas é o ponto de partida de uma renovada caminhada paroquial à luz do processo catecumenal. Palavra chave neste particular parece ser um 'novo contato' através do qual podem nascer verdadeiros processos de iniciação cristã. A quais momentos e oportunidades nos referimos? Primeiramente aqueles momentos kerigmáticos já existentes, ainda que esporádicos, via de regra, momentos chaves na vida de alguém, sejam nos pedidos de sacramentos, na celebração do batismo, da confissão, bodas, exéquias. Numa palavra mais exata, os vários momentos, inclusive aqueles de 'prestação de serviços' de que a paróquia dispõe podem se tornar momentos fortes de possibilidade de um anúncio e encontro mais contundente da proposta do Evangelho. Reafirmamos a convicção de que a quem busca 'serviços religiosos', pode-se oferecer o início de um contato e de uma proposta mais real, não contundo, sem uma revisão da pastoral sacramental. Tentativas de aproximação das pessoas com frequência paroquial periódica não podem ser negligenciadas. Para muitos, a missa dominical é a única oportunidade de que a paróquia dispõe para o novo anúncio ou de uma renovada reiniciação cristã. Para a maioria dos já iniciados é igualmente a celebração eucarística ou da Palavra o único momento para o alimento da fé. Resulta disto, a liturgia apresentar-se na atualidade como potencialidade kerigmática, o que requer, no entanto, um estilo litúrgico em perspectiva missionária. $\mathrm{O}$ tradicional paradigma de preceito dominical que dificilmente inicia, nem muito menos alimenta a fé, deve voltar a ser lugar de anúncio, de catequese viva, de encontro entre irmãos. Neste particular, os símbolos, os espaços celebrativos, a linguagem, os métodos, revestem-se de instrumentais pré-catecumenais, ou seja, já são por si mesmos anunciadores da mensagem cristã.

Não se pode deixar de mencionar a importância das homilias, desde que sejam homilias missionárias, fundamentada na Palavra de Deus, que desperta a fé e saiba interpretar os sinais de Deus nos acontecimentos da vida ${ }^{539}$. Com sabedoria afirma Cozzens: “A pregação é bem-sucedida quando leva a assembleia

\footnotetext{
539 Cf. FLORISTÁN, C. Para compreender a paróquia, op. cit., p. 94. "É um fato repetido e comprovado que a maior parte das homilias correspondentes às eucaristias dominicais são classificadas pelos leigos de 'longas', 'vazias', aborrecidas', 'anacrônicas', 'sem comunicação". Ibid., op. cit., p. 94; cf. ALDAZÁBEL. Funciona la comunicación en nuestras celebraciones? Phase 107, 1978, pp. 459-478.
} 
à oração ... O teste de um verdadeiro sermão é que ele pode ser convertido em oração" 540 .

A riqueza da liturgia catecumenal, com sua variedade de símbolos e ritos, são potencialidades de iniciação, e podem lançar luzes para o conjunto da liturgia paroquial, sejam nos momentos sacramentais ou nos demais momentos celebrativos. Por outro lado, vale lembrar que a liturgia catecumenal não está isenta do perigo de cair no mero ritualismo sem alma, que nada fala ao processo de crescimento formativo do catecúmeno. Importa percebe a inter-relação entre a liturgia catecumenal com seus ritos específicos e a totalidade da liturgia paroquial. Se a paróquia não está consciente da importância da liturgia como catequese viva, não serão aquelas liturgias e ritos próprios do catecumenato vistos anteriormente que serão iniciáticas, pois essas são reflexos daquela e vice versa.

Mesmo que não entremos com vigor na reflexão dos novos meios de comunicação, uma paróquia que não investe na pastoral da comunicação, que se faça presente no vasto mundo das redes sociais, como lugar privilegiado para o anúncio, com muita probabilidade estará com seu futuro comprometido. Importa perceber que a paróquia se vê desafiada a uma tripla missão: No fim da 'civilização paroquial' cabe a ela a tarefa de apresentar e reapresentar a Pessoa de Jesus Cristo para os indiferentes, de uma maneira dinâmica e convicta, muito mais por testemunho do que por demonstração teórica; alimentar a fé dos já iniciados, e purificar a fé dos 'frequentadores', por vezes à busca de serviços religiosos. Uma atenção especial a esses pode fazer a diferença. Embora a motivação primeira seja a busca de serviços religiosos, pode-se gerar um encontro entre ele e a Igreja, ou melhor, entre ele e Jesus Cristo.

\section{2 .2}

\section{A (re) descoberta de novos espaços de anúncio}

Potencializar os caminhos já existentes para o primeiro e o segundo anúncios é necessário, mas não o suficiente, pois fundamental é investir em novos areópagos, sobretudo, para o mundo dos adultos, criar novos meios de anúncio que despertem e promovam o encantamento e reencantamento com a proposta

${ }^{540}$ COZZENS, D. B. A face mutante do sacerdócio: reflexão sobre a crise da alma do sacerdote. São Paulo: Loyola, 200, p. 116. 
cristã. Otimizar as oportunidades já existentes diz respeito ao nível mais intraparoquial, cuja urgência é clara, haja vista o número de pessoas que 'frequentam' a paróquia por ocasiões pontuais, ou os vários 'níveis' de pertença eclesial de que a paróquia é composta. Com a mesma motivação kerigmática a paróquia é convocada a buscar caminhos para um movimento centrífugo, um anúncio extraparoquial, o que exigirá a descoberta e a criação de espaços alternativos, móveis e flexíveis de presença da Igreja. Se com razão se fala de 'rede de comunidades', não deve ser estranho o termo 'redes de anúncio do evangelho', isto é, o esforço ininterrupto para fazer-se presente em instâncias diversas da sociedade para apresentar a pessoa de Jesus Cristo. Torna-se imperioso uma presença pública nas artérias da sociedade, no mundo da saúde, da educação, da solidariedade social, das comunicações mediáticas, das famílias, dos jovens etc ${ }^{541}$. "Se quisermos que o Evangelho continue presente no espaço público, que a cultura, e não só os indivíduos, seja evangelizada, o Evangelho deve estar presente nas grandes redes da sociedade" 542 .

Se em tempos de divórcio entre fé e cultura, 'cristãos não nascem mas se tornam', também é verdade que os mesmos não se tornam automaticamente. Tornam-se à medida que a Igreja souber com criatividade e zelo pastoral se aproximar dos mais diversos ambientes onde vivem os filhos e filhas de Deus.

A lamentável realidade da 'crise da chegada' ou do 'sacramento do adeus' denuncia o vasto campo de atuação paroquial, sem desconsiderar a dificuldade de chegar novamente até essas pessoas. Conseqüentemente, projetos pastorais que não se concentrem tão somente em torno dos ritos ou sacramentos, mas ao redor da vida cotidiana, dos problemas reais e dos vários ambientes, é decisivo para o futuro pastoral da instituição paroquial. Vale lembrar que a etimologia da paróquia aponta para essa presença eclesial junto às pessoas e situações; estar junto a. "O substantivo paroikía pode ser traduzido por morada, habitação em pátria estrangeira. $\mathrm{O}$ adjetivo paroikós equivale a vizinho, próximo, que habita junto ${ }^{\prime 543}$.

\footnotetext{
${ }^{541}$ ROUTHIER, G. Reajustamentos pastorais à medida dos actuais desafios, op. cit. In: BORRAS, A.; ROUTHIER, G. A nova paróquia, op. cit., p. 194.

${ }^{542}$ Ibid., p. 195.

${ }^{543}$ CONFERÊNCIA NATIONAL DOS BISPOS DO BRASIL. Comunidade de comunidades: uma nova paróquia (texto ainda não publicado), op. cit., n. 163. "Na Bíblia grega, aparecem três palavras ligadas à noção de paróquia: o substantivo paroikía, significando estrangeiro, migrante; o
} 
Para a quinta Conferência episcopal, as principais exigências da missão estão no investimento em 'centros de irradiação missionária' (DAp, 306). Se o mesmo documento não deixa muito claro em que consistem tais centros, urge criatividade para a implantação de novos modelos de presença nos mais diversos ambientes da sociedade. Criatividade esta que é determinante para se chegar aos lugares mais fechados, como condomínios, escolas, comércio, ambiente estudantil e educacional, universidades, hospitais, os mais diversos grupos profissionais, moradores de rua, prédios, favelas e outros ambientes mais reclusos. "À semelhança da Kénosis trinitária, a ação pastoral que não sai de si para os diversos encontros históricos, perde sua identidade" ${ }^{544}$. Nesses lugares, sobretudo, importa a paróquia abrir-se a novas formas de evangelização, sem ser tão somente a sacramentalização. Muito pertinente é a pergunta de Paulo Sues. "Como transformar estruturas de supervisão, de visitas rápidas e horas marcadas, em estruturas de presença inculturada? O povo prefere um pastor tocável a um padre fórmula $1 ", 545$.

Interagir com esses ambientes, reinventar a presença nesses lugares, é catecumenato em potencial, ou mais especificamente, pré-catecumenato em potencialidade. Esperar que se apresentem simpatizantes à iniciação cristã contradiz o espírito do pré-catecumenato, que tem como princípio gerar filhos na fé, que por sua vez depende de uma estrutura eclesial kerigmática, missionária.

O pré-catecumenato propriamente dito poderá ser realizado igualmente nestes ambientes, os quais tornaram lugares de iniciação, redes de précatecumenato. Novamente a máxima de Tertuliano é bem vinda, pois se 'cristão não se nasce, mas se torna', então, urge criar espaço de gestação. No tocante à iniciação à vida cristã, o que não é mais cabível, em tempos de crise do institucional, é contentar-se tão somente com ações paroquiais costumeiras, ou convite dispersos e generalizados que dificilmente chega ao endereço do coração das pessoas. “.... carecemos de outros espaços onde estabelecer um primeiro

verbo paroikein, designando viver junto a, habitar nas proximidades, viver em casa alheia (cf. $R t$ 2,1 ss) ou em peregrinação e a palavra paroikós, usada tanto como substantivo quanto adjetivo". Ibid., n. 162.

${ }^{544}$ Cf. AMADO, J. P. Deus e a Cidade: chances e desafios para a experiência cristã de Deus em contexto condominial. Tese doutorado em Teologia. PUC/RJ Pontifica Universidade Católica, 1999 , p. 527.

${ }^{545}$ SUES, P. 'Não tenhais medo'! Da dificuldade de construir a 'nova paróquia”. In: Revista pastoral. Renovação das paróquias e da Igreja, ano 55, Janeiro, fevereiro de 2014, p. 18 . 
contato com as pessoas mais afastadas e não temos atividades moveis que nos permitam estar diferentes redes e em diversos campos"546. Lamentavelmente, "na melhor das hipóteses, diziam, a paróquia conhece o esposo, o padre, o homem privado (a mulher, a mãe), mas nunca o homem público"547. Percebe-se tratar-se de uma revisão da carga cultural de sacramentalização que tem marcado a paróquia por séculos. Não se pode negar que, no lugar de propor à comunidade a missão como ideal de vida cristã, acabamos propondo a instituição, e por consequência, a sacramentalização da pastoral ${ }^{548}$. O sacramento, bem sabemos, é uma consequência de uma adesão à proposta do Reino, vivida na Igreja. O processo de crescimento na fé é permanente; os sacramentos alimentam esse processo e têm consequências na vida (cf. DNC, 50).

Ao trazer o tema da missão para a conversa com a iniciação cristã catecumenal, de modo especial com a etapa pré-catecumenal, evidenciou-se a convicção de que o catecumenato, se assumido com coragem será um acertado caminho para dar às nossas paróquias estruturas mais missionárias, do mesmo modo que somente uma paróquia com vigor missionário é capaz de levar a sério a iniciação cristã catecumenal, caso contrário, o catecumenato será uma peça estranha. Em outros termos, sem paróquias missionárias a iniciação cristã será doutrinal, nocional, reforçando assim a tendência institucional da paróquia, do mesmo modo que sem a priorização da iniciação cristã, a paróquia continuará a desenvolver meras 'atividades de manutenção', de tendência sacramentalista. Levar a sério a iniciação cristã é condição necessária para a renovação missionária da paróquia, é o que afirma Aparecida com outras palavras ao dizer que "uma comunidade que assume a iniciação cristã renova sua vida comunitária e desperta seu caráter missionário" (DAp, 291). Sinal mais evidente de uma comunidade madura e iniciada na fé é o compromisso com a missão. "A ação evangelizadora da comunidade cristã, primeiramente no próprio terreno e depois, mais além, como participação na missão universal, é o sinal claro da maturidade da fé" (RMi,

\footnotetext{
${ }^{546}$ Ibid., p. 201.

${ }^{547}$ Église-Monde. Bulletin du Centre Protestant d'Études et de Documentation 100 (Maio 1965), pp. 21-28, citado por ROUTHIER, Reajustamentos pastorais à medida dos actuais desafios, op. cit. In: BORRAS, A. ROUTHIER, G. A nova paróquia, op. cit., p. 202.

548 RASCHIETTI, E. Paróquia missionária á luz do Documento de Aparecida. Procedimentos fundamentais, (apresentação), op. cit., p. 8.
} 
49). Fundamental é assumir a missão como possibilidade e condição de renovação paroquial $^{549}$.

\section{2 .4}

\section{O acompanhamento pessoal do pré-catecumenato e a acolhida paroquial}

Para além da possível distância entre teoria e efetiva prática précatecumenal, em determinados ambientes, por motivos já mencionados, não se pode subestimar a pertinência de sua proposta acolhedora, que de imediato nos faz questionar a burocracia e o peso da estrutura paroquial, com pesadas cargas de horários, expedientes, agendas.

A pedagogia pré-catecumenal pode lançar luzes na busca de novas estruturas paroquiais de acolhida e de ações mais personalizadas. Diante de uma cultura que gera o anonimato e a solidão, o material pastoral de que dispõe o précatecumenato são a acolhida generosa, o estar junto, a escuta gratuita, a partir do qual são fornecidos os primeiros fundamentos da fé cristã. Em outras palavras, para melhor entender o alcance da acolhida na etapa pré-catecumenal pode-se buscar como chave de leitura as relações verdadeiras e espontâneas, o contato pessoal, a oração, o diálogo fraterno, os encontros informais, a atenção personalizada; em uma palavra, a gratuidade de estar juntos. O simpatizante deve ser acolhido pelo introdutor a qualquer tempo durante o ano. Verifica-se, portanto, uma estrutura de acolhida contínua e permanente.

A acolhida catecumenal remete e aponta para o acompanhamento personalizado, aja vista a importância considerável que o livro litúrgico atribui ao ministério do introdutor, conforme já recordado por nós no capítulo precedente. São eles que acompanham os candidatos, apresentam-no à comunidade, e deles dão testemunho (Cf. RICA, 43; 104), e quando finalizada sua função, com o rito de admissão, continuam a acompanhar os catecúmenos durante toda a formação, além do que 'seu ofício continua sendo importante quando o neófito, tendo recebido os sacramentos, precisa de ajuda para permanecer fiel às promessas do batismo" (RICA, 43 e 235).

\footnotetext{
${ }^{549}$ Cf. CODINA, V. A missão como renovação eclesial. In: BRIGHENTI, A.; HERMANO, R. (orgs). A missão em debate: provocações à luz de Aparecida. São Paulo: Paulinas, 2010 (Coleção Ecclesia 21).
} 
A instituição do ministério do introdutor revela não tratar-se de um serviço periférico. Lamentável o fato de ser um ministério ainda iminente, quando não pouco conhecido e valorizado, talvez reflexo de uma herança eclesial que apresenta dificuldades no trabalho personalizado, corpo a corpo, cuja estrutura da massa está acostumada a trabalhar com multidões. Em certos lugares, o précatecumenato não é realizado, atropela-se essa fase e inicia-se já na etapa catecumenal; em outros lugares é o próprio catequista que faz às vezes de introdutor ${ }^{550}$.

Propomos não somente o investimento deste ministério na iniciação à vida cristã, mas pensá-lo, com as devidas adaptações, para além do catecumenato, em vista de ações pastorais personalizadas e progressivas. A título de exemplo, podemos mencionar o quanto a pastoral da acolhida pode ser incrementada a partir da dinâmica pré-catecumenal, ou o quanto as funções atribuídas ao introdutor pode beneficiar e trazer inspiração ao acompanhamento pastoral, como por exemplo, aos noivos, aos pais e padrinhos que pedem o batismo aos filhos, e que geralmente recebem cursinhos doutrinais e moralistas, cujo conteúdo não passa pelo coração nem gera experiência e encontro. A acolhida pré-catecumenal pode ajudar a repensar os pressupostos pastorais em vista de uma autêntica renovação pastoral que proponha itinerários de fé, itinerários formativos, inclusive após a celebração dos sacramentos. Outros exemplos podem levar ao acompanhamento dos primeiros anos de matrimônio, a chegado do filho. Ou então pensemos no vasto campo das visitas às famílias que chegam ou partem em busca de melhores condições de vida, a atenção aos novos moradores ${ }^{551}$, as visitas domiciliares nos momentos familiares marcantes pela alegria ou pela dor. Se nem sempre é fácil o acesso a determinados ambientes, quantas portas se abrem em momentos fortes da vida das famílias. Uma paróquia que não investe na pastoral

\footnotetext{
${ }^{550}$ Em nossa experiência pastoral e nos relatos ouvidos nas comunidades cristãs, o précatecumenato é o tempo mais difícil de ser levado a cabo. Na tentativa de responder o porquê disto, certamente entram na resposta a realidade de uma cultura paroquial não acostumada ao trabalho e acompanhamento pessoal, a evangelização corpo-a-corpo. Sem a cultura da acolhida na paróquia, nas pastorais, o ministério do introdutor pode soar como algo não somente desconhecido mas estranho.

${ }^{551}$ Dentre outras sugestões para a acolhida dos novos moradores, José Carlos Pereira, estudioso na área da Pastoral da acolhida, menciona a "possibilidade de fazer uma celebração de acolhida em sua casa. Se a família permitir, será uma boa ocasião de estreitar os laços entre os recém-chegados e a comunidade". PEREIRA, J. C. Pastoral da acolhida: guia de implantação, formação e atuação dos agentes. São Paulo: Paulinas, 2009 (Coleção discípulo missionário), p. 92.
} 
da visitação corre o sério risco de fechar-se em si mesma, contribuindo desta forma para tornar a paróquia ainda mais centrípeta. Ela precisa manter-se interessada com tudo o que passa no municípo, na região, no bairro. Só assim evitará o espírito de capelinha, e dará provas de solidariedade ${ }^{552}$.

$\mathrm{Na}$ fuga da solidão das grandes metrópoles não são poucos os que procuram a Igreja na busca de atenção e de acolhimento. A última Conferência dos bispos do nosso continente recorda que "nossos fiéis procuram comunidades cristãs onde seja acolhidos fraternalmente e se sintam valorizadas, visíveis e eclesialmente incluídos" (DAp, 242). Em contrapartida, por termos uma configuração paroquial de massa, carecemos de estruturas de acolhida, que são muito mais do que a entrega de folhetos na entrada da Igreja. Urgente desenvolver em nossas paróquias, nas pastorais e movimentos uma cultura de acolhida, que mais do que uma pastoral específica trata-se de uma atitude transversal, a perpassar todo a agir da Igreja. Recorda a Conferência dos Bispos do Brasil, que "hoje a religião é mais acolhida do que herdada. O espaço que a Igreja pode ocupar na vida das pessoas depende da qualidade do acolhimento e do testemunho, e não mais do prestígio da instituição"553.

A acolhida fundamenta-se no valor de cada pessoa, na atenção à sua individualidade. Neste particular, exige-se da pastoral paroquial uma atenção especial ao processo de cada indivíduo, capaz de propor caminhos diversificados. Não se pode impor a todos, de forma indiscriminada, idênticas exigências, quando na realidade as pessoas são diversas e os níveis de proximidade com a vida eclesial são diferentes ${ }^{554}$. Resulta disto, os já mencionados cursinhos sacramentais serem questionados, por vezes mais exigência canônica do que oportunidade de novo anúncio acolhedor. As mesmas normas para todos, sem levar em consideração a individualidade de cada fiel, dificulta um trabalho de iniciação ou iniciação à fé.

\footnotetext{
${ }^{552}$ Cf. BORRAS, A. Aspectos teológicos e canônicos da remodelação paroquial. In: BORRAS, A.; ROUTHIER, G. A Nova paróquia, op. cit., p. 139. ${ }^{553}$ CONFERÊNCIA NACIONAL DOS BISPOS DO BRASIL. Catequese para um mundo em mudança: cada um ouvia na sua própria língua. São Paulo: Paulus, 1994, n. 25.

${ }^{554}$ Cf. CONFERÊNCIA NATIONAL DOS BISPOS DO BRASIL. Diretrizes Gerais da Ação Evangelizadora da Igreja no Brasil. 2003-2006. São Paulo: Paulinas, 2003 (Coleção Documentos da CNBB, n. 71), n. 35.
} 
A secretaria paroquial desempenha, ainda que não o único, um lugar fundamental do exercício da acolhida, o que exige pessoas com espiritualidade e formação para o atendimento kerigmático. Faz-se necessário sensibilidade para a atenção e acolhida diferenciadas, por exemplo, aos que estão de luto (morte, exéquias, sétimo dia...), aos que estão em festa, felizes pelo nascimento de uma criança e pedem a realização do batizado, casamento, aos membros da comunidade (dizimistas, agentes de pastoral...), aos afastados ou praticantes ocasionais ou desconhecidos.

Outras pistas de ação estão na criação de grupos de plantão de acolhida, propiciadores de atendimentos individuais, quebrando assim o anonimato urbano; na promoção de momentos de oração, de partilha, de aconselhamento, grupos de ajuda na recentralização do eu, cujos espaços e momentos favoreçam o desabafo e a orientação pessoal ${ }^{555}$; momentos de escuta, valorização da oração pessoal, auxiliada com métodos individuais de oração e com auxílio de material catequético e eletrônico, como livros, como vídeos, audiocassetes; melhoras nos ambientes litúrgicos; celebrações bem preparadas e criativas, com horários adaptados ao ritmo de vida urbana, nas quais haja a valorização do corpo, do movimento, dos símbolos, afeto, enquanto expressão do eu ${ }^{556}$. Sujeitos primordiais da acolhida paroquial são igualmente a imensa multidão de sofredores que circundam a paróquia. Há todo um contingente de gente perdida, no anominato: "catadores de lixo, mendigos, desempregados, prostitutas, meninos e meninas de rua, migrantes sem teto são alguns dos "sobrantes" que a cidade exibe sem conseguir integrar" 557 . Acolhida, neste caso, significa ir ao encontro, ir 'às periferias existenciais', preocupação central do pontificado do papa Francisco.

$\mathrm{O}$ que dizer da acolhida às pessoas em situações irregulares na Igreja, muitas vezes tratados sem a devida dignidade de que são portadoras? Dependendo de como as coisas (proibições) são ditas, podem gerar um distanciamento definitivo da Igreja.

\footnotetext{
${ }_{555}$ Cf. AMADO, J. P. Experiência Eclesial em Mundo Urbano, op. cit. In: Atualidade Teológica, v. 9, op. cit., pp. 156-157.

${ }^{556}$ Cf. TÔRRES, M. G. Arte e litúrgica. Tempo, corpo e festa. In: Grande Sinal 3, 1998, pp. 277284.

${ }^{557}$ CONFERÊNCIA NATIONAL DOS BISPOS DO BRASIL. Igreja e Comunicação. Rumo ao novo milênio. (Estudos da CNBB 75), n. 38.
} 
Fato é que o investimento nos ministérios de plantão, da escuta, do aconselhamento, ou outras iniciativas que caminhem nesta direção, com disponibilidade de atendimento fora da rigidez do tradicional expediente, dão à paróquia um rosto mais pessoal, vale dizer, catecumenal, possibilitando que os fiéis sintam-se acolhidos, e mais do que isso, sujeitos. Nesta perspectiva, acolhida já é, em si mesmo, primeiro anúncio. Em todas estas ações estão os germes do pré-catecumenato, ou em outros termos, são também pré-catecumenato em potencialidade. A nomenclatura é irrelevante. Fundamental é o espírito que motiva tas ações. Com outras palavras, o pré-catecumenato começa antes mesmo do itinerário catecumenal, ou ao menos deveria se assim.

Acolhida paroquial remete ao cuidado preferencial aos mais necessitados, maior atendimento aos doentes, solitários, enlutados, deprimidos e dependentes químicos, aproximar maior das famílias, do povo de rua, das populações indígenas, quilombares, vítimas da miséria e violência urbanas ${ }^{558}$.

Nossa intenção, neste intem, foi evidenciar que a dinâmica précatecumenal convida a instituição paroquial a voltar-se ao sujeito da fé, aos interlocutores da mensagem cristã, numa atenção pessoal, ao mesmo tempo em que o pré-catecumenato se faz dependente de uma configuração paroquial em movimento de permanente acolhida. Se a acolhida é a característica ao redor da qual gira a dinâmica pré-catecumenal, para levar a cabo o objetivo à qual ela se propõe, decisivo é a existência de comunidades e estruturas eclesiais acolhedoras.

\section{3}

O desafio de superar as estruturas obsoletas que não favorecem à missionariedade

O caminho percorrido até o momento, no tocante ao diálogo entre précatecumenato e paróquia, evidenciou a possibilidade-necessidade de um novo vigor missionário paroquial. Contudo, bem sabemos que as atuais estruturas de que dispõe a paróquia, nem sempre favorecem a missionariedade. "Há muita energia desperdiçada em manter estruturas que não respondem mais às inquietações atuais" ${ }^{559}$.

\footnotetext{
${ }^{558}$ Cf. CONFERÊNCIA NATIONAL DOS BISPOS DO BRASIL. Comunidade de comunidades: uma nova paróquia, (texto ainda não publicado), op. cit., n. 49.

${ }^{559}$ Ibid., n. 44.
} 
Aparecida, em continuidade com o espírito renovador das outras conferências episcopais, com veemência chama a atenção para a "necessidade de uma renovação eclesial que implica reformas espirituais, pastorais e também institucionais" (DAp, 367). O mesmo documento, no número anterior, insiste que "nenhuma comunidade deve isentar-se de entrar decididamente, com todas as forças, nos processos constantes de renovação missionária e de abandonar as ultrapassadas estruturas que já não favoreçam a transmissão da fé” (DAp, 365).

A 'conversão pastoral' e missionária exige necessariamente a 'conversão estrutural', pois estrutura também é mensagem. Sem o suporte institucional que corresponda a mensagem, toda ação cai na inanição, a missão em mera campanha e o discipulado em voluntarismo ${ }^{560}$.

Importa perceber a íntima aproximação entre renovação estrutural e missionariedade paroquial, onde se pode também afirmar a relação dialética, bem percebida pelo papa Francisco em Evangelli Gaudium:

A reforma das estruturas, que a conversão pastoral exige só se pode entender neste sentido: fazer com que todas elas se tornem mais missionárias, que a pastoral ordinária em todas as suas instâncias seja mais comunicativa e aberta, que coloque os agentes em atitude constante de 'saída' e, assim, favoreça a resposta positiva de todos aqueles a quem Jesus Cristo oferece a sua amizade (EG, n. 41).

Ao mesmo tempo, o papa também sabe que "o que derruba as estruturas caducas, o que leva a mudar os corações dos cristãos é, justamente a missionariedade" ${ }^{561}$. Continua o pontífice:

A "mudança de estruturas" (de caducas a novas) não é fruto de um estudo de organização do organograma funcional eclesiástico, de que resultaria uma reorganização estática, mas é consequência da dinâmica da missão. $\mathrm{O}$ que derruba as estruturas caducas, o que leva a mudar os corações dos cristãos é justamente a missionariedade. Daqui a importância da missão paradigmática $^{562}$.

O cuidar demais das estruturas tende a esquecer da missão, o que evidencia, mais uma vez, a necessidade de relativizar certos aspectos estruturais,

\footnotetext{
${ }^{560}$ Cf. BRIGHENTI, A. Para uma recepção criativa da proposta missionária de Aparecida. In: Encontros Teológicos. ITESC, n. 51. Florianópolis-SC, 2008, p. 14.

${ }^{561}$ PAPA FRANCISCO. Pronunciamentos do Papa Francisco no Brasil. São Paulo: Paulinas; Loyola, 2013, pp.71-72.

562 PAPA FRANCISCO. Encontro com os dirigentes do CELAM.
} 
abandonar outros, e transformar outros. À medida que a paróquia 'sair', tanto mais as estruturas obsoletas serão renovadas, e á media que esta se renovar, melhor a paróquia será missionária.

A pergunta, entretanto, permanece: qual a configuração paroquial que melhor corresponde ao objetivo de levar a cabo o rosto de uma paróquia missionária, kerigmática, catecumenal que desperte vocações ao cristianismo, que insira os simpatizantes na vida concreta de uma comunidade cristã, e que sustente a fé dos já iniciados? Se nem sempre temos a resposta, fundamental é que se permita ouvir a voz do Espírito que fala pela mediação do humano e da cultura, como bem rememora França Miranda: “A Igreja não existe fora do mundo e nem recebe do céu os meios para se comunicar e se organizar ao longo da história. Tais instrumentos the são oferecidos pela sociedade" ${ }^{, 563}$.

A possibilidade de uma nova configuração estrutural em muito depende da compreensão que se tem da paróquia. Nesta perspectiva, intuições acertadas sobre a paróquia, iluminadoras de possíveis novos perfis estruturais, nos vem das Conferências episcopais latino americanas e caribenha. Para Medelín, paróquia é "um conjunto pastoral vivificador e unificador das comunidades de base' (Medellín, 15.13). Destacam-se na definição acima as expressões 'conjunto pastoral' e 'comunidades de base'. Puebla, por sua vez, entende a paróquia como "centro de coordenação e animação de comunidades, grupos e movimentos" (Puebla, 617). Santo Domingo entende a paróquia como rede de comunidades (DSD, 1.2.2). Aparecida, além de retomar o mesmo conceito da Conferência anterior, pontua o fato das paróquias serem 'chamadas a ser casas e escolas de comunhão' (DAp, 170). Em todas as definições percebe-se a recusa ao centralismo estrutural em benefício de uma maior comunhão e valorização das diversas formas comunitárias que formam a paróquia.

Se não dispomos de um novo modelo paroquial, é possível, a partir da compreensão que se tem da paroquial, e atentos ao que a pedagogia catecumenal nos tem a dizer, encontrar indicações ou pistas, relatos de experiências que lançam luzes para possibilidades de novas configurações. Motivados por tais definições que nos são oferecidas pela eclesiologia de nosso continente, chamaremos a

${ }^{563}$ MIRANDA, M. F. Verdades urgentes para uma renovação eclesial. In: Revista Eclesiástica Brasileira, fasc. 289, v. 73, janeiro/março 2013, p. 131. Recomendamos a leitura na íntegra do artigo citado. 
atenção para três aspectos importantes a serem sempre mais assumidos na renovação estrutural da paróquia. São elas: 'unidade pastoral', 'comunidade de comunidades', 'pequenas comunidades'. Vale ainda lembrar que em muitas realidades paroquiais já se vive tal espírito, enquanto que em outras, o assunto é novidade.

\subsection{1}

\section{Uma nova relação com o território}

Verifica-se a necessidade de uma maior articulação das paróquias entre si, seja a partir de um trabalho em rede transparoquial, seja a partir de uma mentalidade global que faça frente ao autosuficientismo estrutural que tem caracterizado a paróquia desde tempos remotos. Não é nossa intenção apostar em um modelo pronto ${ }^{564}$. Fundamental são a criatividade e sensibilidade pastorais, a partir das quais novas propostas vão ganhando corpo e tornando-se realidade.

Um exemplo de um novo modo de organização paroquial vem da Europa, cujas experiências pastorais recebem o nome de ‘unidade pastoral ${ }^{565}$. Ora por necessidade numérica, em função da diminuição do clero, ora motivada pelo espírito missionário que busca configurações mais adequadas a nossa época, surgem aqui e acolá iniciativas que mostram ser possíveis novos rostos estruturais de paróquias. Vale lembrar, entretanto, que aquelas iniciativas motivadas meramente pela escassez de sacerdotes parecem não estarem livres de condicionamentos, pois neste caso está mais uma vez o clero no centro das decisões ${ }^{566}$.

Trata-se de esforço de repensar uma nova relação paroquial com o território, em um trabalho conjunto para unir forças em busca de um novo modo

\footnotetext{
${ }^{564}$ Importa perceber a possibilidade de um novo mapa geográfico da paróquia, seja a partir de mais paróquias com um único sacerdote, sejam paróquias com sacerdotes e comunidade religiosa; várias paróquias com uma equipe de sacerdotes, junção de várias paróquias, etc.

${ }^{565}$ A bibliografia é vasta. Cf. BRAMBILLA, F. G. La parrocchia oggi e domani, sobretudo a segunda parte da obra 'Nuove vie della pastorale'. Confira nas páginas 341-344 a vasta bibliografia citado pelo autor. No intuito de conhecer mais de perto uma realidade de 'unidade pastoral', cf. o resumo feito por um estudante de teologia sobre a experiência pastoral da Diocese da França, Poitiers, uma diocese rural, com dois grandes polos urbanos (Poitiers e Chatellerault). VANCONCELOS, P. In: http://repositorio.ucp.pt/bitstream/10400.14/2997/1/Novas\%20formas.pdf, acessado $10 \mathrm{de}$ dezembro de 2013, Portugual.

${ }^{566} \mathrm{Se}$ é verdade que determinadas iniciativas são motivadas pela diminuição do clero, a motivação primeira não deveria ser esta, e sim uma maior interdependência a partir dos novos espaços urbanos e da lógica da mobilidade.
} 
de fazer pastoral. Devem entram em cena, entre outros aspectos, a espiritualidade de comunhão, a ministerialidade, a redescoberta da Igreja local, a territorialidade, a comunhão financeira, como testemunho de comunhão. A questão central das ‘unidades pastorais' é a percepção cada vez maior de que as paróquias não são auto-suficientes, mentalidade mais do que comum, segundo a qual cada paróquia faz tudo e em nada depende das outras. Se oferece vantagens por ser abertas a todos e para tudo, a organização pastoral paroquial tradicional traz consigo o perigo do autosuficientimo, ou paroquialismo, outro nome para expressar a mesma realidade. Daí nossa insistência na importância de um novo olhar teológico-pastoral para a Igreja local. Verifica-se, portanto, uma nova possibilidade de habitar o território, que parta de um conjunto maior que o limite canônico constitutivo da paróquia. Em outros termos, novos modelos que partam da cidade que é o "novo templo de Deus"567 é fundamental para o futuro da paróquia. O novo perfil de fiel não se identifica apenas com a sua ou com uma paróquia, mas ao contrário, tem várias redes de pertença ${ }^{568}$. As iniciativas das 'unidades paroquiais' estimulam necessariamente, portanto, o alargamento territorial, isto é, uma presença mais elástica e capilar. Nesta perspectiva, não se trata tão somente de multiplicar as paróquias, mas de uma organização mais articulada de presença da Igreja sob o território ${ }^{569}$. Não se trata igualmente de destituir as paróquias, mas o esforço de colocá-las em rede, a partir de um novo conceito de territórialidade, ciente de que o princípio territorial não pode ser a única forma de organizar a comunidade eclesial.

Se teologicamente são irrenunciáveis a experiência e pertença comunitária, pastoralmente não deveria a Igreja, no atual contexto de urbanização, incentivar experiências socioculturais, mais do que territoriais, que possibilitem a

\footnotetext{
567 SEIBOLD, J. Dios habita em la ciuda. Hacia um nuevo paradigma de la Pastoral Urbana em América Latina u el Caribe. Textos da Universidade Ibero-Americana, Congresso Internacional da Pastoral Urbana, México, 2007.

${ }^{568}$ BORRAS, A. Aspectos teológicos e canônicos da remodelação paroquial. In: BORRAS, A.; ROUTHIER, G. A nova paróquia, op. cit., p. 122.

${ }^{569}$ BRAMBILLA. La parrocchia oggi e domani, op. cit., p. 185. O último censo mostra que no Brasil tem-se aumentado o número de paróquias, o contrário da realidade europeia, onde se verifica o crescente número de fechamentos de paróquias. A pergunta que permanece é se resolve simplesmente o aumento de paróquias, quando se constata simultaneamente a diminuição de fiéis católicos. $\mathrm{O}$ fortalecimento do institucional não significa necessariamente o fortalecimento da religiosidade, nem uma maior qualidade da iniciação cristã.
} 
experiência comunitária e o encontro com Jesus Cristo? ${ }^{570}$. Se o alargamento territorial favorece a formação de novas comunidades e na vivência eclesial, não seria oportuno relativizar o geográfico, quando possível e necessário, para que possa emergir os 'centros de irradiação', os pólos de evangelização? "O indispensável é o senso de pertença, não importando se ele ocorre no território de residência ou em outro lugar... Para a vivência comunitária, a estabilidade é condição indispensável. A territorialidade geofísica, não"571. Conclui o atual documento da CNBB sobre a paróquia: "o referencial mais importante para o ser humano de hoje é o sentido de pertença à comunidade e não tanto o território" ${ }^{\text {"572. }}$.

Uma das novidades pós-modernas em todos os setores sociais é a organização em rede, haja vista a atual predominância das redes virtuais. No campo da pastoral o espírito não pode ser outro, pois cada vez com mais rapidez qualquer forma de isolamento eclesial tende a se tornar uma prática não só ultrapassada como inviável para os resultados almejados na evangelização. O fim da 'civilização paroquial' pressupõe o fim daquele pensamento paroquial que se entende como um castelo que tudo possui em si. A novidade inclui, portanto, a tentativa de tirar a paróquia e o clero do seu isolamento, o que não será possível se não se repensar a figura do padre, ao mesmo tempo que se promova novos 'sujeitos' e novos agentes pastorais. As unidades pastorais, o ‘trabalho em rede', independentemente da nomeclatura que se dê, mais do que uma estratégia pastoral, querem ser sinais de koinonia de comunidades que se auto-percebem como porção do conjunto da Igreja local. Fundamental é garantir uma maior aproximação e atuação sob o conjunto da cidade, o que é uma das exigências nevrálgicas da pastoral urbana. É sempre oportuno recorrer à história a qual recorda a evangelização realizada em nível de cidade. Ao estruturar-se como paróquia no mundo rural, tal dimensão foi enfraquecendo-se, cuja maior consequência foi a paulatina transformação paroquial em pequenos feudos, isolados, sem aquele dinamismo missionário originário. O desafio da paróquia é superar a auto-suficiência e auto-referência e abrir-se para cima, para os lados,

\footnotetext{
${ }^{570}$ Cf. AMADO, J. P. Experiência eclesial em mundo urbano ( $2^{\circ}$ parte), op. cit. In: Atualidade Teológica, v. 9, op. cit., p. 161.

571 Ibid., p. 164.

${ }^{572}$ Cf. CONFERÊNCIA NATIONAL DOS BISPOS DO BRASIL. Comunidade de comunidades: uma nova paróquia, (texto ainda não publicado), op. cit., n. 40.
} 
para baixo. Nos termos de Santo Domingo, a "paróquia urbana deve ser mais aberta, flexível e missionária, permitindo uma ação pastoral transparoquial e supraparoquial” (DSD, 257).

Faz-se oportuno sempre lembrar que a riqueza de uma paróquia pode ajudar na fraqueza de outra. Os primeiros elementos da rede paroquial são as outras paróquias da região, mas não menos importante os institutos religiosos, as obras sociais católicas, os movimentos eclesiais, enfim, todas as forças vivas realidade local. Faz parte igualmente desse tecido em rede as instituições públicas $^{573}$.

Para tanto faz necessário um "plano de pastoral orgânico e articulado que se integre a um projeto comum às outras paróquias, comunidades de vida consagrada, pequenas comunidades, movimentos e instituições que incidem na cidade" (DAp, 518) ${ }^{574}$. Imprescindível se torna a elaboração de um projeto comum em nível de cidade, elaborar uma equipe que pense a evangelização do conjunto da cidade em vista de uma evangelização mais ampla. Sua função é igualmente integrar os vários projetos paroquiais, pois "a unidade da pastoral urbana exige uma conciliação de todos os programas particulares" ${ }^{275}$.

Na mesma perspectiva, outras iniciativas são o que o eclesiólogo Almeida chama de 'conselho urbano', lembrando sempre que os contextos urbanos pedem serviço em nível urbano. A eficácia da evangelização exige estrutura intermediária entre paróquia e diocese, a partir de áreas específicas e ambientais, como cultura, educação, saúde. Neste sentido, “as comunidades são pensadas em forma de rede, levando em conta que as pessoas, no mundo urbano, tecem relações, em diversos âmbitos, com uma multiplicidade de outras pessoas, lugares, funções e serviços, também na Igreja" ${ }^{576}$. Paróquias espalhadas podem ser unificadas, atendidas por

\footnotetext{
${ }^{573}$ Cf. BARGHIGLIONI, E. e MARIELLA; MEDDI, L. Il futuro della parrocchia, op. cit., p. 84. "Trabalhar em rede significa antes de tudo reconhecer e ativar competências objetivas. Um jornaleiro é um ponto de comunicação, a pediatra é um ponto salvífico, os comerciantes são possíveis soluções caritativas, os centros esportivos lugares de socialização e transmissão cultural. Trabalho de rede significa procurar tais interventos em nome da comunhão humana”. Ibid., p. 84. 574 Neste particular, há de se reconhecer a contribuição de Libânio para entender as lógicas da cidade, organizada em rede e tecidos. Cf. sua obra intitulada As lógicas da Cidade. O impacto sobre a fé e sob o impacto da fé. São Paulo: Loyola, 2001. Nas palavras do autor, "a cidade é uma teia de aranha tanto no seu interior como nas suas conexões com as outras cidades. Simboliza a grande obra construtora do ser humano, revelando sua verdadeira natureza social". Ibid., p. 27.

575 COMBLIN, J. Pastoral urbana: o dinamismo na evangelização. Petrópolis: Vozes, 1999, p. 50.

${ }^{576}$ GODOY, M. "Paróquias renovadas à luz de Aparecida". In: Vida Pastoral. Revista bimestral para sacerdotes e agentes de pastora, ano 49, n. 261, julho-agosto, 2008, p. 15.
} 
uma equipe de leigos, religiosos ou padres, animadas pelo bispo. Paróquias situadas em grandes centros comerciais, que abrangem escritórios, bancos, comércio, podem ter uma presença e ação pastoral estruturada de forma diferente de paróquias situadas em outros ambientes. Paróquias com perfis de santuários, fundamental é o investimento na acolhida e no atendimento pessoal.

A especialização de paróquias, de certa forma já tratado por nós, não contradiz o espírito do trabalho em rede, mas antes a supõe e a exige. Almeida sugere que as paróquias não precisariam ser todas iguais, mas especificar-se para determinadas serviços ${ }^{577}$, o que exige certamente muita maturidade e conversão de mentalidade para o trabalho em conjunto. Determinadas paróquias, por exemplo, poderiam se concentrar em preparação ao batismo, com disponibilidade de horários; outras, na área da saúde, atender a todos os hospitais, outras, no atendimento aos funerais e famílias, e pós-luto, outras, em nulidades de matrimônio e acompanhar os casais em segunda união, etc ${ }^{578}$.

Certamente o leitor estará se perguntando se tais especializações não reforçaria a paróquia como 'agência de serviços'? Se o risco sempre bate à porta, o diferencial será sem dúvida o projeto pastoral que nela houver. “( ...) o sinal paroquial que temos que oferecer, sempre muito mais eloquiente, incita-nos, no interesse pela missão, a salvar o máximo de superfície de contado com os nossos contemporâneos $^{579}$. A predominância, senão exclusividade de modelos unívocos de paróquia, diante de uma sociedade plural e setorizada parece dificultar um trabalho melhor elaborado, segundo as necessidades locais. Por que não, então, investir em especialização de paróquias, em determinadas frentes de evangelização, como por exemplo, religiosidade popular, outro paroquial que invista no catecumenato, na ação social? Urge passar "de uma Igreja monolítica ao pluralismo" $" 580$.

Portanto, urge integrar em rede todas as formas de presença cristã as atividades pastorais, os lugares de peregrinação, os santuário mariano, mosteiros, casas de retiro, formação cristãs... Nunca é demais insistir que em todos esses

\footnotetext{
577 ALMEIDA, J. Paróquia, comunidades e pastoral urbana, op. cit., p. 234.

${ }^{578}$ MIKUSZKA, L. Por uma paróquia missionária à luz de Aparecida, op. cit.

579 BORRAS, A. Aspectos teológicos e canônicos da remodelação paroquial, op. cit. In: BORRAS, A.; ROUTHIER, G. A nova paróquia, op. cit., p. 125.

${ }^{580}$ CALAMAN C. ANTONIAZZI, A. A Pastoral Católica: do primado da instituição a primado da pessoa. In: FABRI, M. A. (orgs.). Sob o fogo do Espírito. São Paulo: Paulinas, 1998, p. 257.
} 
ambientes é possível, não sem esforço, potencializar a iniciação à vida cristã, a partir de um projeto maior que o restrito terreno paroquial ${ }^{581}$.

\section{3 .2}

\section{'Comunidade de comunidades'}

Se anteriormente apontávamos para a possibilidade de um novo modelo de relação das paróquias entre si e com a Igreja local, cujo espírito aponta para a unidade pastoral, é oportuno agora, a partir do mesmo espírito de comunhão e abertura, refletir sobre o que Aparecida intitula 'comunidade de comunidades' ou 'rede de comunidades' (DAp, 309; 5170), cuja expressão é tomada de Santo Domingo (DSD, 58). É este também o título do último documento aprovado pela CNBB, "Comunidade de comunidades: uma nova paróquia. A conversão pastoral da paróquia".

A concretização de uma paróquia que visibilize uma estrutura organizada em 'comunidade de comunidades' aponta, além de outras dimensões, para três aspectos vitais no tocante a sua revitalização: a já mencionada nova compreensão de paróquia, a valorização de cada comunidade local e, conseqüentemente, o rompimento com um modelo centralizador, voltado à matriz.

'Rede de comunidades' ou comunidade de comunidades' apresenta-se como a melhor definição para intuir o sentido estrutural do que é chamada a ser a paróquia. O conceito denuncia, em primeiro lugar, aquela mentalidade tão enraizada e nefasta à vivência comunitária da fé que associa paróquia com a Igreja matriz, e por extensão, com a casa e com a secretaria paroquiais. A problemática se instala quando se assimila paróquia com imagem física das igrejas, e com agravante ainda maior quando associada com a matriz, quando na verdade paróquia quer ser as relações comunitárias que se estabelecem entre os fiéis e entre as comunidades cristãs. É profundamente lamentável quando "a capela funciona com a missa periódica e a festa do padroeiro; outros sacramentos e

\footnotetext{
${ }^{581}$ Vale ainda recordar que o Canon 516, \& 2 prevê o exercício da responsabilidade pastoral, sem ser assumir o ministério de pároco, devido sua condição. Em outros termos, há a possibilidade canônica de um cargo pastoral não paroquial, onde se exige certas necessidades da missão.
} 
atividades convergem para a matriz. Em muitos lugares, a capela só funciona conforme o calendário de visita do padre" ${ }^{\natural 82}$.

Portanto, 'comunidade de comunidades' quer sinalizar um novo modo de organizar a estrutura social da paróquia, não mais pensada a partir do centro ou de cima, mas de relações entre iguais, o oposto de uma organização piramidal, cujo modelo clássico é o da matriz-filiais. Enquanto que em organização piramidal a base executa o que a ponta decide, 'comunidade de comunidades' opera uma reviravolta na organização, nas decisões e, acima de tudo, nas relações. Em uma palavra mais contundente, comunidade de comunidades é o incentivo às bases, cientes de que a base gira em torno das pessoas, ao passo que em estrutura piramidal pairam outras prioridades.

Paróquia não é somente e em primeiro lugar uma estrutura administrativa, jurídica, mas uma realidade viva formada por pessoas e comunidades que professam a mesma fé. $\mathrm{Na}$ organização em 'rede de comunidades' assistimos a passagem de uma compreensão por demais institucional, burocrática, centralizadora, para um novo modelo capaz de reconhecer a importância e a igualdade de todos os núcleos comunitários que compõem o conjunto eclesial chamado paróquia. Vale lembrar que em muitas realidades já há a organização em 'redes de comunidades'; em outras, falta clareza do que se trata.

A recomendação do Conselho presbiteral de Madrid conserva sua atualidade: "Reconhece-se que uma via eficaz para a renovação comunitária da paróquia é a criação de uma ou várias comunidades-fermento, que sejam como que o núcleo animador da própria instituição paroquial"583. Não serão nem a matriz nem o clero nem o burocrático o centro ao redor do qual giram as comunidades eclesiais. O mesmo princípio que reza que não existe igreja universal a não ser através de auto-realização das Igrejas locais pode ser aplicado no tocante à paróquia, ou seja, não existe paróquia a não ser na e através das comunidades que a compõe.

Somente uma estrutura de 'comunidade de comunidades' é capaz de promover uma sadia autonomia e valorização de conjunto comunitário, bem como a criação de novas formas comunitárias, o despertar de novas lideranças. Torna-se

582 BASSINI, P. F. Paróquia, rede de comunidades. In: Vida Pastoral. Revista bimestral para sacerdotes e agentes de pastoral, ano, 52, n. 279, julho-agosto de 2011, p. 20.

${ }_{583}$ Conselho Presbiteral de Madrid, Las comunidades eclesiales, 16 de Novembro de 1981. 
evidente que as pistas pastorais apontam para a descentralização, isto é, na criação de maior número possível de grupos pequenos e diversificados, em ambientes diversos, de tal forma que a paróquia se torne uma realidade plural e comunitária. Antoniazi, com apurada intuição pastoral, afirma que a paróquia deve se complexificar internamente, ou seja, favorecer a diversidade de grupos, abertos à iniciativa dos indivíduos e grupos ${ }^{584}$, o que significa, na prática, permissão, autonomia e estímulo a grupos para se reunirem também em ambientes diversos, ao estilo das Cebs, círculos bíblicos, novas comunidades.

Fundamental neste processo é o cuidado pastoral para evitar o enquadramento das atuais e novas formas comunitárias em modelos tradicionais, centralizadores e burocráticos. Urge dar-lhes liberdade de ação, incentivar a criatividade pastoral, promover a autonomia madura e responsável. Exige-se aqui uma inversão de compreensão, como bem recorda o teólogo Caldentey. Não se trata, pois, de pôr a base a serviço dessas instituições, mas estas a serviço da base. Dentro desta perspectiva, a paróquia deverá evoluir para novos modelos organizativos, novos esquemas de vinculação institucional, novos modelos de conexão entre ação pastoral e realidade humana, com mais possibilidade de identificação de vida cristã ${ }^{585}$.

Muito incentivado pelos documentos eclesiais tem sido a setorização da paróquia, sem sombra de dúvida um novo horizonte pastoral a contribuir com a descentralização estrutural ${ }^{586}$. Trata-se de um procedimento favorável à evangelização por possibilitar atingir mais pessoas ${ }^{587}$. Tais setores podem ser formados por ruas, bairros, prédios, área geográfica, etc. Importante que cada

\footnotetext{
${ }^{584}$ ANTONIAZZI. A. A. Princípios teológico-pastorais para uma nova presença da Igreja na cidade, op. cit. In: ANTONIAZZI, A.; CALAMAN, C. (orgs). A presença da Igreja na cidade, op. cit., p. 95.

${ }^{585}$ CALDENTEY, J. Significado das Comunidades Cristãs de Base para a Igreja. Concilium: Revista Internacional de Teologia. Petrópolis: Vozes, v. 11, fasc. 104, 1975, p. 473.

${ }^{586}$ Uma visita ao documento de Aparecida pode ser oportuna: "Levando em consideração as dimensões de nossas paróquias, é aconselhável a setorização em unidades territoriais menores, com equipes próprias de animação e de coordenação, que permitam uma maior proximidade com as pessoas e grupos que vivem na região. É aconselhável que os agentes missionários promovam a criação de comunidades de famílias que fomentem a colocação em comum de sua fé crista e das respostas aos problemas" (DAp, 372).

${ }^{587}$ PEREIRA, J. C. Paróquia missionária á luz do Documento de Aparecida, op. cit., p. 90.
} 
paróquia, de acordo com a sua realidade, urbana ou rural, encontre a melhor maneira de criar esses setores ${ }^{588}$.

Por fim, importa estar convencido de que a setorização, o investimento em foranias, regionais, vicariatos são realidades que favorecem a organização de uma paróquia de 'comunidades de comunidades' (DAp, 517). "Setorizar não significa dividir a paróquia, mas descentralizá-la, fazendo com que o anúncio corra por todas as suas extremidades" 589 .

\section{3 .3}

\section{A opção por pequenas comunidades}

Tão urgente quanto uma estrutura eclesial de 'comunidade de comunidades' é a reflexão acerca do tamanho das mesmas. Lembremo-nos que o assunto já foi introduzido quando afirmávamos ser a paróquia uma estrutura de massa ${ }^{590}$. A rejeição às macro-estruturas, somado ao anonimato eclesial, leva-nos à conclusão de que a revitalização paroquial tem passagem obrigatória no investimento e criação de pequenas comunidades. Novas e pequenas comunidades, grupos de partilha e convívio têm surgido de forma espontânea, o que mostra ser, hoje, pequenos grupos uma tendência sociocultural. Todos esses grupos apresentam uma característica em comum: renunciam a formalidade e a estruturas pesadas em busca de relações mais espontâneas.

As paróquias, sobretudo as situadas em áreas com alto índice de urbanização não podem criar uma verdadeira consciência comunitária se não em nível de pequenas comunidades, vivas e dinâmicas, as quais favorecem a troca de

\footnotetext{
${ }^{588}$ Ibid., op. cit., p. 37.

${ }^{589}$ MIKUSZKA, G. L. Por uma paróquia missionária à luz de Aparecida, op. cit., p. 144.

${ }^{590}$ De acordo com Joel Portella, a definição eclesiológico-pastoral de massa refere-se "a um tipo de espaço sociocultural de atuação pastoral onde os níveis de engajamento não chegam ao estágio comunitário". AMADO, J. P. Experiência eclesial em mundo urbano ( $2^{\circ}$ parte), op. cit. In: Atualidade Teológica, v. 9, op. cit., p. 158. Segundo o mesmo autor, os espaços pastorais de massa e comunidades não se excluem, mas se complementam, ou seja, as manifestações de massa têm um sentido e função pastoral, pois atuam são fornecedores socioculturais em meio ao anonimato das cidades. Daí a importância de romarias, procissões. Cf. Ibid., p. 159-160. Em contrapartida, o conceito de base, ou núcleo, possibilita uma melhor compreensão do que sejam pequenas comunidades e seu valor eclesiológico, e aqui nos remetemos à compreensão de Igreja da base de Pedro Ribeiro de Oliveira: significa eclesiologicamente, "o núcleo mínimo da comunidade eclesial definida como Povo de Deus", grupos de caráter local, nos quais, embora com ênfase diferente das paróquias, se realizam as mesmas atividades regulares da Igreja católica". OLIVEIRA, P. A. R. "CEB: unidade estruturante da Igreja" In: BOFF, C.; LESPAUPIN, I. et al. As Comunidades de Base em questão. São Paulo: Paulinas, 1997, p. 5ss
} 
experiência e uma participação mais ativa de seus membros. São as pequenas comunidades espaços privilegiados para um maior sentimento de pertença, para o aprofundamento da partilha, para uma vida litúrgica mais celebrativa, para o despertar da consciência crítica frente às injustiças sociais e possibilidade de uma formação mais intensa. Aparecida, nos números 178 e 179, apresenta alguns benefícios de pequenas comunidades: relação de amizade, confiança, respeito, maior conhecimento da Palavra de Deus, educação dos adultos na fé, surgimentos de novos de diversos ministérios. Importa perceber que comunidade não é uma categoria abstrata, tem rosto, identidade, tamanho, e quando for de 'tamanho humano' será capaz de realizar as dimensões antropológicas, as quais, sem estarem em contraposição à fé, são partes constitutivas dela.

O tema não é novidade. O valor das pequenas comunidades já é reconhecido pelo Concílio Vaticano II.

A vivência da comunhão a que foi chamado, o cristão deve encontrá-la na 'comunidade de base', ou seja: em uma comunidade local ou ambiental, que corresponda à realidade de um grupo homogêneo e que tenha uma dimensão tal que permita a convivência pessoal fraterna entre seus membros (LG 8; GS 40).

Puebla, por sua vez, ao definir a paróquia como "centro de coordenação e animação de comunidades, grupos e movimentos" (Puebla, 644), pedia a 'multiplicação de pequenas comunidades territoriais ou ambientais que correspondam a uma evangelização mais personalizante" (Puebla, 111). Santo Domingo, em sintonia com as Conferências Episcopais anteriores, percebe a defasagem da vida moderna e os critérios da organização da vida paróquia, e propõe uma estrutura que favoreça o surgimento de pequenas comunidades eclesiais, as quais geram maior responsabilidade de leigos e impulso à missão (DSD, 60), pois "através das pequenas comunidades, poder-se-ia também conseguir chegar aos afastados, aos indiferentes e aos que alimentam descontentamento ou ressentimento em relação à Igreja" (DAp, 325).

A Exortação Apostólica Evangelii Nuntiandi afirma que as pequenas comunidades cristãs, comunidades de base, são o lugar privilegiado para se viver a verdadeira comunhão eclesial (EN, 58). Nesta perspectiva, afirma Comblin, 
"vencem as religiões que conseguem formar pequenos grupos com bastante intimidade, intercâmbio e vida comunitária" ${ }^{" 591}$.

Pequenas comunidades favorecem a descentralização do atendimento e a promoção de novas lideranças. Mais do que multiplicar o trabalho do pároco, trata-se de uma nova organização, onde haja maior delegação de responsabilidade para leigos e religiosos que atuam na paróquia ${ }^{592}$. Exemplo disto é quando se setoriza ou cria-se novas comunidades, precisa surgir novas lideranças para assumir a coordenação e os trabalhos. Outra observação é o fato do tamanho das comunidades e grupos coadunar-se com a prioridade à acolhida e ao acompanhamento personalizado, abordados anteriormente, uma vez que se torna impossível imaginar uma atenção maior à individualidade e à promoção do relacionamento fraterno em mega-estruturas.

Há de ressaltar que o investimento em pequenas comunidades acarreta o risco do fechamento em si mesmas. Urge acompanhamento pastoral para não promover o isolamento. Para que sejam evangelizadoras e fiéis à vocação cristã, exige-lhes a abertura à comunhão entre si bem como com as instâncias eclesiais, sejam essas diocesanas ou paroquiais ${ }^{593}$. Nem o enquadramento que mata e sufoca, nem tão pouco o isolamento grupal. Necessário é promover e incentivar a autonomia criativa, com novas e diversificados espaços comunitários, sem abrir mão da comunhão eclesial. Investir em pequenas narrativas eclesiais para que essas possam ser acolhidas na grande narrativa eclesial. Pistas de ação apontam para a promoção de momentos celebrativos no grande corpo eclesial, como expressão de inserção e comunhão com a pastoral orgânica de cada diocese (cf. DAp, 184).

Torna-se evidente que a revitalização paroquial somente pode vir pela base e da base, ou seja, no investimento de comunidade de 'tamanho humano', na descentralização da Igreja templo na busca do comunitário em níveis mais básicos onde sejam possíveis laços mais profundos e familiares. Importante não perder de vista a estrutura comunitária da Igreja primitiva, cuja base eram as casas domésticas, casas essas que por sua vez recebem um conceito mais amplo que a

${ }^{591}$ COMBLIM, J. Os Desafios da cidade no século XXI, op. cit., p. 21.

${ }^{592} \mathrm{Cf}$. CONFERÊNCIA NATIONAL DOS BIPOS DO BRASIL. Comunidade de comunidades: uma nova paróquia, op. cit., n. 246.

${ }^{593}$ Cf. BESTARD, J. La Parroquia, institución Eclesial isustituible e insuficiente. In. Phase, julioagosto, n. 208, 1995, p. 276. 
família por incluir também funcionários, e às vezes amigos e auxiliares no comércio $^{594}$. Não se trata simplesmente de um retorno às igrejas domésticas, nem um resgate unilateral das Cebs, nem tão pouco anular os momentos de grandes eventos. O que está em jogo é não perder de vista o espírito e a organização horizontal com que tais formas comunitárias vivenciaram - vivenciam a fé cristã comunitariamente. "A pequena comunidade não anula a individualidade nem a personalidade, mas potencializa o 'eu', de modo que tenha valor, voz, dignidade e vem entre o 'nós, num equilíbrio que leva a reconhecer e aceitar as diferenças e pluralidades" ${ }^{\prime 595}$.

A fim de não perder de vista o objetivo maior da presente pesquisa, há de se perguntar pela relação entre pequenas comunidades e iniciação cristã catecumenal. A partir do exposto até o momento, a resposta parece soar clara. A proposta catecumenal de iniciação cristã, que tem como objetivo inserir gradualmente o catecúmeno no seio de uma comunidade, leva-nos a concluir que são estruturas de pequenas comunidades que melhor favorecem a experiência concreta e imediata de comunhão, o crescimento da fé, a participação mais ativa na liturgia, da vida e da missão da comunidade e da corresponsabilidade eclesial. São elas igualmente que garantem uma maior perseverança após os sacramentos, minimizando assim o 'sacramento do adeus, bem recordado pelo Diretório Geral de Catequese. "A pequena comunidade é (...) uma meta adequada para acolher aqueles que concluíram um itinerário de catequese" (DGC 264). Indiscutivelmente, é muito mais fácil dar uma atenção maior à iniciação cristã onde as comunidades têm estruturas de base, nas quais se potencializam a acolhida, o acompanhamento, o ingresso na gramática litúrgica da fé. Vale lembrar que muitos ao procurar a Igreja e se inscrever no catecumenato não almejam de imediato os sacramentos, mas a acolhida e experiência comunitária, as quais são muito mais possíveis em grupos menores. Ainda que o RICA não aborde expressamente o tamanho dos grupos catecumentais, as orientações pastorais pedem que o número de catecúmenos em cada grupo seja reduzido.

${ }^{594}$ Cf. MEEKS, W. A. Os primeiros cristãos urbanos: o mundo social do apostolo Paulo. São Paulo: Paulus, 1992 (Coleção Bíblia e sociologia), p. 12.

${ }^{595}$ MIKUSZKA, G. L. Por uma paróquia missionária à luz de Aparecida, op. cit., p. 162. 


\section{3 .4}

\section{A contribuição das Comunidades Eclesiais de Base}

Dentre os grupos de base, são as CEBs referência permanente de comunidade eclesial, seja pela qualidade de vida fraterna que promovem, seja pela forte consciência sociopolítica e interação fé-vida. No entender do documento de Puebla,

As pequenas comunidades, sobretudo as Comunidades Eclesiais de Base, criam maior inter-relação pessoal, aceitação da Palavra de Deus, revisão de vida e reflexão sobre a realidade à luz do Evangelho; acentua-se o compromisso com a família, o trabalho, o bairro e a comunidade local (Puebla, 629).

Faz-se necessária, no início deste tópico, uma observação no que diz respeito ao conceito comunidade, de que as CEBs são legítimas portadoras. Verifica-se uma tendência eclesial do uso do termo comunidade como sinônimo para a vasta constelação de formas comunitárias existentes, sem o devido cuidado de salvaguardar a especificidade inerente a cada grupo ${ }^{596}$. Queremos chamar a atenção para não confundir CEBs com outras formas de comunidades, ou com 'pequenas comunidades', igualmente válidas e necessárias para a revitalização eclesial. Não se pode confundir CEBs com 'grupos eclesiais' (que seriam as tais 'pequenas comunidades'). As CEBs não são 'pastorais' nem 'movimentos' e muito menos 'grupos eclesiais'; elas são 'estrutura de Igreja'597.

\footnotetext{
596 Deixemo-nos questionar pela pergunta de Sérgio Coutinho: "Haveria alguma diferença entre uma 'Comunidade Eclesial de Base' e, por exemplo, o 'Terço dos Homens'? Uma 'Nova Comunidade' é a mesma coisa que o 'Apostolado da Oração' ou o 'Grupo de Oração' na linha da Renovação Carismática Católica? Um grupo de pessoas que se reúne na capela para fazer a Novena de Natal é a mesma coisa que a comunidade reunida no domingo, na mesma capela, para a Celebração da Palavra? Mesmo que possuam carismas e serviços diferentes, todas elas podem ser chamadas de 'pequenas comunidades"? Para os membros da comissão redatora das atuais Diretrizes Gerais da Ação Evangelizadora da Igreja no Brasil (DGAE) parece que sim. Em sua $1^{\circ}$ versão redigida, encontramos no n. 56 o seguinte: 'A busca sincera por Jesus Cristo faz, então, surgir a correspondente busca por novas formas de vida comunitária, todas comumentes chamadas de pequenas comunidades. Mais adiante, o texto dessa mesma $1^{\circ}$ versão da DGAE, no mesmo parágrafo, procura explicitar o que seriam essas comunidades: 'São as comunidades eclesiais de base e inúmeras outras formas de pequenas comunidades (...)". COUTINHO, S. R. CEBs e "pequenas comunidades": identidades e diferenças. In: OROFINO, F. et all. (orgs). CEBs $e$ os desafios do mundo contemporâneo. Iser Assessoria. São Paulo: Paulus, 2012, pp. 86-87.

${ }^{597}$ Cf. Ibid., p. 91. Na Exortação Pos-sinodal Ecclesia in America, o Papa João Paulo II apresenta uma oportuna diferenciação entre comunidades e pequenas comunidades. Ele substitui o último termo por 'grupos eclesiais': "Um meio de renovação paroquial, particularmente urgente nas paróquias das grandes cidades, pode ser encontrada talvez considerando a paróquia como comunidade de comunidades e de movimentos. Por isso, é oportuno a formação de comunidades e de grupos eclesiais de tal dimensão que permitam estabelecer verdadeiras relações humanas. (...)
} 
Feitas essas observações, partimos do princípio de que as CEBs, herança da Igreja da América latina, são sempre referencial para repensar a estrutura da Igreja em geral e da paróquia em particular, pois favorecem um novo estilo de relações, 'reiventam a noção de comunidade'. Vale lembrar que o documento de Aparecida afirma a importância das CEBs na renovação paroquial, por fazer o povo "chegar a um conhecimento maior da Palavra de Deus, ao compromisso social em nome do Evangelho, ao surgimento de novos serviços leigos e à educação da fé dos adultos" (DAp, 178). O recente documento da CNBB sobre a paróquia igualmente reconhece o valor das Comunidades Eclesiais de Base na conversão pastoral; reconhece sobremaneira a centralidade na Palavra de Deus e na eucaristia, o valor do pequeno grupo, a fraternidade e a solidariedade ${ }^{598}$.

Caracterizam-se pela nova forma de estruturar a Igreja, conforme o nome mesmo as define: pela base. Não se trata naturalmente de uma nova pastoral, mas de uma nova organização eclesial, de uma diferente configuração, caracterizada pelo protagonismo dos leigos, amor à Palavra de Deus, no engajamento sócio político, nas celebrações festivas e inculturadas, na preocupação com a ecologia e com a prática ecumênica ${ }^{599}$. Para Faustino Teixeira, "as comunidades eclesiais de base significa a Igreja toda em movimento de conversão aos pobres"600.

Elas mostram ser possível uma modificação na estrutura eclesial, na organização, na participação, nas decisões, nas relações. Os elementos principais da fé cristã são potencialmente vividos com mais facilidade em comunidade de base. Não dispomos de tempo para um aprofundamento do processo de iniciação cristã nas CEBs, mas tudo indica que nelas o crescimento na fé ganha em qualidade, pelas características supracitadas. As palavras de João Paulo II, pronunciadas em 1990 na RM 51, são elucidadoras.

\footnotetext{
A instituição paroquial, assim renovada, 'pode suscitar uma grande esperança. Pode formar comunitariamente as pessoas, oferecer ajuda à vida familiar, superar a condição de anonimato, acolher as pessoas e ajudá-las a inserir-se no âmbito local e da sociedade”. EAm, 41; cf. DGAE, n. 93, que remete ao DAp, 172-173.

${ }^{598}$ CONFERÊNCIA NATIONAL DOS BISPOS DO BRASIL. Comunidade de comunidades: uma nova paróquia, op. cit., n. 230.

${ }^{599}$ Cf. MENEZES, D. H. L. CEBs: do Vaticano II a Aparecida. In: CEBs e os desafios do mundo contemporâneo. Iser Assessoria, op. cit., p. 32.

${ }^{600}$ TEIXEIRA, F. A fé na Vida: estudo teológico-pastoral sobre a experiência das CEBs no Brasil. São Paulo: Loyola, 1987 (Coleção Fé e Realidade 23), p. 175.
} 
O indivíduo cristão faz nelas uma experiência comunitária, onde ele próprio se sente um elemento ativo, estimulando a dar sua colaboração para proveito de todos. Desse modo, elas tornam-se instrumentos de evangelização e de primeiro anúncio, bem como fonte de novos ministérios.

Destaca-se igualmente nas CEBs, além do elemento 'comunidade', as notas 'base' e 'eclesial'. Fala-se de base enquanto 'unidade estruturante', 'célula de estruturação eclesial' da Igreja ${ }^{601}$. É a Conferência de Medellin que melhor expressa o significado de base

A vivência da comunhão a que foi chamado, o cristão deve encontrá-la na 'comunidade de base': ou seja, em uma comunidade local ou ambiental que corresponda à realidade de um grupo homogêneo e que tenha uma dimensão tal que permita a convivência fraterna entre seus membros ... (... ) Ela é, pois, célula inicial da estrutura eclesial e foco de evangelização e, atualmente, fator primordial da promoção humana e do desenvolvimento (Medellín, 15, 10).

Os elementos da eclesialidade, segundo Pedro Ribeiro de Oliveira, estão na celebração dominical (na ausência de sacerdote, a celebração da Palavra), na existência de um conselho comunitário ou equipe de coordenação pastoral, e na existência de grupo de reflexão bíblica ${ }^{602}$.

Ao trazer a realidade das CEBs para o diálogo, evidencia-se a possibilidade da promoção de estruturas comunitárias de base, as quais não são tão somente questão sociológica, mas fundamentalmente teológica, cuja inspiração são neotestamentárias. Muito mais poderíamos refletir sobre a contribuição das CEBs para a renovação paroquial, contudo, não queremos perder o foco da questão, que pretende ser o diálogo entre paróquia e catecumenato.

Chegamos, assim, ao término do diálogo entre a primeira etapa catecumenal com as dimensões da paróquia que mais se aproximam do espírito e objetivos pré-catecumenais. Sobressaíram, evidentemente, a missão, o anúncio e a acolhida, entre outros. Entramos em dimensões paroquiais que à primeira vista podem parecer desnecessários ou distantes das intuições pré-catecumenais, e aqui nos referimos às dimensões estruturais da paróquia. Importa não perder o foco da questão. Elementos estruturais são constitutivos da comunidade eclesial, e bem sabemos que nem sempre determinada estrutura favorece a missão. Nossa

${ }^{601}$ COUTINHO, S. R. CEBs e "pequenas comunidades": identidades e diferenças, op. cit. In: OROFINO, F. et all. (orgs). CEBs e os desafios do mundo contemporâneo. Iser Assessoria, op. cit., p. 91.

${ }^{602}$ Cf. RIBEIRO, P. CEBs: unidade estruturante de Igreja, p. 130 ss. 
intenção foi trazer para o debate, provocados pela metodologia catecumenal, estruturas paroquiais que dificultam a transmissão e a vivência da fé, e consequentemente propor mudanças que as favoreçam. Em outras palavras, para que a paróquia seja iluminada pelo espírito querigmático pré-catecumenal, exige mudanças estruturais em sua configuração. Importa perceber quais aspectos estruturais que dificultam a missionariedade paroquial, quais estruturas devem ser abandonadas e outras que precisam ser assumidas. Sobressaíram 'a unidade pastoral', o trabalho em rede, comunidade de comunidades, pequenas comunidades, sempre a partir de uma maior valorização da Igreja local.

\section{4}

\section{A segunda etapa do processo catecumenal e o 'catecumenato permanente': a formação permanente a serviço da renovação paroquial}

Passaremos à inter-relação entre formação inicial e formação permanente da fé cristã. Na primeira parte do atual capítulo procuramos mostrar as implicações mútuas entre pré-catecumenato e a dimensão kerigmática, missionária e personalizada da ação evangelizadora na paróquia. Veio à tona o quanto a proposta pastoral do pré-catecumenato desafia a paróquia à missionariedade, ao primeiro anúncio, à atenção primordial à pessoa, à acolhida e à escuta. Na continuidade do diálogo entre a pedagogia da iniciação cristã catecumenal e a instituição paroquial, entraremos agora no jogo dialético entre a segunda etapa do itinerário catecumenal, denominado catecumenato, que dialogará com a formação permanente na paróquia, por nós intitulado 'catecumenato permanente', isto é, a contínua formação dos já iniciados na fé, sejam eles seminaristas, ministros ordenados, catequistas, agentes da evangelização nas mais diversas frentes. Se a paróquia precisa ser lugar da iniciação à vida cristã, necessita igualmente assumir o compromisso com o contínuo aprofundamento da fé dos já iniciados, caso contrário, correria o risco de, conforme um ditado bastante brasileiro, 'morrer na praia', ou seja, todo o esforço da transmissão da fé, de iniciar na vida cristã tornase em vão quando não se oferece estruturas comunitárias para viver essa mesma fé e aprofundá-la continuamente. Formação inicial e formação permanente, ou se preferirmos, iniciação cristã catecumenal e 'catecumenato permanente' são, portanto, momentos distintos de um único processo na busca da construção de 
comunidades eclesiais adultas, isto é, da renovação paroquial à luz da pedagogia catecumenal. São igualmente momentos distintos de um único processo no permanente mergulho no Mistério, que não cessa com a iniciação à vida cristã, ou com a recepção dos sacramentos, justamente por tratar-se do Mistério, que se revela, permanecendo sempre Mistério.

\section{4 .1}

\section{A inteligibilidade da fé na iniciação à vida cristã}

O caminho percorrido até o momento, seja na análise da realidade cultural e religiosa do primeiro capítulo, seja no estudo teológico da iniciação cristã do segundo capítulo, trouxe à tona a necessidade de uma formação religiosa sólida, mais do que em outros tempos, quando hoje, as transformações da mudança de época dificultam não somente a adesão mas principalmente a perseverança na fé. Muitos se empolgam, motivados por uma cultura religiosa pentecostalizada, aquecem o coração, mas acabam sucumbindo diante do exagero do emocional e escassez de um processo de formação-reflexão mais consistente. Em termos mais exatos, se muitos iniciam a caminhada cristã com total empolgação, se professam 'convertidos', mas paulatinamente tamanha convicção se dilui, a razão não se deve em grande parte por carência ou qualidade da formação e excesso do emocional?

Um processo de iniciação à vida cristã que não leve em conta a dimensão formativa, inteligente e reflexiva da fé está sujeito aos ventos do 'transito religioso'. O nó da questão recai sobre a identidade da fé. A fé, por estar inserida nas profundas mutações culturais, marcadas por incertezas e complexidade, exige perguntar-se constantemente por sua identidade. Se em outras épocas o fiel não sentia maiores dificuldades na questão religiosa, hoje, para dar razões de sua esperança diante do atual contexto em que vive, não pode prescindir de um itinerário intenso de conhecimento, discernimento, aprofundamento e reflexão dos elementos centrais da fé que professa. Não se trata tão somente de receber conteúdos, doutrinas ou informações, mas com eles e a partir deles fazer uma assimilação existencial, crítica, reflexiva, espiritual, experiencial e inteligente dos conteúdos fé. Longe de se excluírem, fé e razão se complementam. É sempre atual 
o axioma de Santo Anselmo, segundo o qual 'não compreendo para crer mas creio para compreender'.

Portanto, torna-se evidente que a inteligibilidade da fé é parte constitutiva da iniciação à vida cristã que, por sua dinamicidade, carece de contínuo aprofundamento. A pergunta que permanece e que nos propomos a refletir agora é pela relação entre formação inicial e formação permanente, quando o assunto é renovação paroquial. Em outros termos, se a formação religiosa tem sua centralidade na caminhada do iniciante, não menos vital é ela para o já iniciado. Tal necessária relação diz respeito e contribui com o repensar a configuração paroquial.

\section{4 .2}

\section{A necessária relação entre formação inicial e formação permanente na renovação paroquial à luz do período catecumenal}

O motivo da ênfase na formação permanente e seus necessários desdobramentos, neste segundo ponto do presente capítulo, está no fato de ser ela, a formação da fé, o núcleo central da segunda etapa do itinerário catecumenal. Se a primeira etapa denominada pré-catecumenato prima pela pré-evangelização, pelos 'rudimentos da vida espiritual', pela acolhida, pelos encontros espontâneos, o segundo degrau da caminhada enfatiza, além de outros aspectos, a sólida formação. A partir da celebração do rito de acolhida o catecúmeno ingressa na segunda etapa de sua caminhada rumo à maturação da fé, na qual ele mergulha numa intensa formação catequética, religiosa, bíblico-doutrinal. É o tempo dedicado a uma sólida catequese e a vivência comunitária mais intensa. Nesta etapa, com uma participação maior na gramática da comunidade, na vida litúrgicacelebrativa, o catecúmeno experimenta um período de aprofundamento racional, intelectual, de caracter experiencial dos fundamentos da fé cristã, o que nos permite afirmar ser a formação, portanto, a identidade maior desta etapa da iniciação à vida cristã. Vale ressaltar o aspecto mistagógico e orante desta formação, que "relacionada com o ano litúrgico e apoiada nas celebrações da Palavra, leva os catecúmenos não só ao conhecimento dos dogmas e preceitos, como à íntima percepção do mistério da salvação de que desejam participar" (RICA, 19). A formação consistente da fé cristã diz respeito a uma dimensão tão 
fundamental da iniciação cristã, de tal forma que sem ela não se pode conceber que alguém tenha sido iniciado na fé. A assimilação existencial da Pessoa de Jesus passa pela experiência pessoal e também pela assimilação dos elementos da fé.

Existe uma relação mais do que próxima entre formação inicial e formação permanente da fé. Tal relação não pode ser vista como dois momentos estanques, mas continuidade necessária de um único processo no qual todos nos encontramos, em níveis diferentes, enquanto contínuos iniciantes no Mistério. Se teologicamente podemos afirmar que alguém está iniciado na vida cristã com os sacramentos da iniciação, também se pode concluir que tal iniciação entendida como mergulho no mistério não se conclui com a recepção dos sacramentos. Somos todos eternos iniciantes, não obstantes já iniciados sacramentalmente. O torna-se adulto na fé é um processo mais intenso que o catecumenato, pois depende da continuidade da formação e da vivência da fé.

O nexo entre formação inicial e formação permanente pode ser ainda visualizado no binômio oferecido por Aparecido e do qual estamos fazendo abundante uso: discípulos missionários. O discipulado não termina com a missionariedade, e esta por sua vez não começa somente quando finda o discipulado. O mesmo documento expressa não serem duas realidades dispersas quando, em vez que utilizar discípulos e missionários, opta pela eliminação do artigo $e$. Se todo discípulo é convocado à missão, pode-se afirmar com outros termos que todo iniciado é chamado à formação permanente. Formar discípulos (formação inicial) significa assumir o comprometimento com a formação de missionários (formação permanente). Trata-se da mesma dinâmica existente entre discípulos missionários.

Quando na iniciação cristã a inteligência da fé, a dimensão da formação são comprometidas, torna-se extremamente difícil a perseverança na fé. Nossa ênfase neste particular, na relação entre iniciação cristã e 'catecumenato permanente', quer recordar que a paróquia está a serviço da maturação da fé, e isso significa um compromisso também com a formação permanente. Uma paróquia que não investe no 'catecumenato permanente', na formação continuada de seus agentes e de todos os batizados não somente não conseguirá levar a sério a iniciação cristã catecumenal como também comprometerá a maturidade humana e cristã da paróquia. A deficiência na formação dos agentes de pastoral compromete 
a iniciação cristã em particular e a missão da Igreja em geral. Compromete substancialmente o futuro missionário da paróquia, pois vale lembrar que os iniciantes de hoje serão os missionários de amanhã, e nada mais desgastante à missão do que agentes (iniciados) não preparados. Neste particular, a formação é condição necessária para suscitar nas paróquias lideranças, as quais por sua vez formarão outros líderes, e em cujo movimento multiplicam-se verdadeiros discípulos missionários.

São estas algumas das indicações da relação dialética entre iniciação cristã e permanente iniciação (formação permanente), sem esgotar o assunto. Feitas tais observações, cabe agora aprofundar melhor o lugar da formação permanente no processo de renovação paroquial.

\section{4 .3}

\section{O lugar da formação permanente na renovação paroquial}

A consciência da conexão entre formação inicial e formação permanente deve levar a instituição paroquial a se perguntar pelo lugar que ela dá à formação permanente e continuada de seus paroquianos em geral, e de seus agentes de evangelização em particular.

A renovação trazida pelo Concílio Vaticano II denuncia com veemência o paradigma tradicional segundo o qual cabia somente a padres e consagrados o múnus da missão e, por conseguinte, serem eles os únicos sujeitos de uma formação teológica, pastoral, bíblica, enquanto que os leigos seriam apenas receptores do conhecimento daqueles. Percebe hoje, com aguda clareza, que a consciência da missão requer o direito à formação intensa e de qualidade.

Se a consciência da missão vem tomando corpo na reflexão pastoral e teológica, também se está cada vez melhor percebendo o lugar central da formação, seja para o crescimento pessoal seja para bem realizar o múnus eclesial. Se no item anterior batíamos na tecla da necessidade do primeiro anúncio para fora dos restritos muros dos templos da paróquia para fazer-se presente no vasto campo da sociedade, é preciso agora enfatizar a qualificação dos agentes. Se o leigo é convocado, pela graça do batismo, a atuar na realidade secular, "no vasto campo da política, da realidade social e da economia, como também da cultura, das ciências das artes, da vida internacional, dos meios de comunicação e de 
outras realidades abertas à evangelização" (DAp, 283), verifica-se então que formação permanente não é privilégio mas necessidade, pois o diálogo com esses novos areópagos exige devido preparo e qualificação.

Formar missionários, portanto, para atuar no vasto mundo da sociedade é parte integrante do processo de renovação paroquial. Fazendo novamente uso das sábias palavras de Aparecida, 'formar leigos e leigas para que sejam homens da Igreja no coração do mundo, e homens do mundo no coração da Igreja' (DAp, 209). Se não se realiza uma genuína iniciação cristã sem uma sólida formação, gradual, processual, também não se constrói comunidades adultas e missionárias quando não se investe na formação continuada. Dito diferente, a renovação da estrutura paroquial, para que seja 'comunidade de comunidades' adultas na fé, exige o investimento na formação permanente, formação esta a favor da maturidade do individuo e da comunidade. Uma paróquia que não investe na formação não passará do estágio da 'manutenção pastoral'. Em vários momentos o Documento de Aparecida acena para a conexão entre formação e futuro da paróquia. Com extrema sabedoria afirma que

Os melhores esforços das paróquias neste início do terceiro milênio devem estar na convocação e na formação de leigos missionários. Só através da multiplicação deles poderemos chegar a responder às exigências missionárias do momento atual (DAp, 174).

Continua o Documento: "Se queremos que as nossas paróquias sejam centros de irradiação missionária em seus próprios territórios, elas devem ser também lugares de formação permanente” (DAp, 306).

O dilema da paróquia expresso no binômio 'paróquia x serviço religioso' não será desfeito se não for substituído por outro binômio: paróquia x formação. Investir na formação, primeiramente dos agentes, e ao mesmo tempo oferecer oportunidade de aprofundamento religioso a todos os batizados é, sem dúvida, o caminho mais acertado para chegar a uma paróquia adulta, sem dependência, sem centralismo, sem medo dos leigos em relação ao clero.

O que está em jogo na paróquia é romper com a tendência de simplesmente alimentar as necessidades intimistas e caminhar para a construção de comunidades verdadeiramente iniciadas, as quais passam necessariamente por novas estruturas de formação da fé. Se tal nova estrutura formativa já é uma 
realidade visível na proposta catecumenal, parece não haver muita clareza quando o caminho é a formação permanente. Como renovar a estrutura paroquial quando em muitos lugares a maior parte do orçamento paroquial é gasto na manutenção patrimonial? Uma inversão eclesiológica exige, portanto, maior investimento no patrimônio humano. Não pode ser opcional o investimento em "várias instâncias formativas que assegurem o acompanhamento e o amadurecimento de todos os agentes pastorais e dos leigos inseridos no mundo" (DAp, 306).

Nada mais prejudicial à missão do que agentes não preparados, sobretudo hoje, onde a capacidade do diálogo, o testemunho, a clareza, são características essenciais para alguém se encantar com a proposta cristã. Se o testemunho do missionário é essencial, não menos importante é sua preparação, sua capacidade de dialogar com a atual cultura, com os interlocutores da Boa Nova. Vale lembrar que a formação permanente é condição igualmente para o futuro do catecumenato, ou seja, condição para que a paróquia seja catecumenal é a formação de catequistas no espírito catecumenal. Não basta implantar o catecumenato quando os agentes não estão preparados para o novo paradigma de transmissão da fé. Assim como condição para uma paróquia ministerial é a formação dos padres para o trabalho em equipe, para a colegialidade, para a mudança de mentalidade.

Aquilo que abordamos sobre paróquias em rede pode ser aplicado no quesito formação. O trabalho formativo em rede possibilitará que uma determinada paróquia ou comunidade ofereça determinada formação, enquanto que outra disponibilizará de mais tempo para centrar-se em outra modalidade formativa. Casa de formação, institutos teológicos, casas religiosas podem ser excelentes centros de irradiação a serviço da formação dos batizados.

Iluminada pela proposta do catecumenato, há de se ressalvar que tal formação precisa revestir-se igualmente de um novo paradigma. $\mathrm{O}$ tradicional paradigma nocional, que consiste na mera transposição de conhecimentos já não pode mais ser denominado formativo, pois formação não consiste apenas em repassar conteúdos, mas uma assimilação intelectual, celebrativa dos elementos da fé, isto é, uma formação mistagógica.

$\mathrm{Na}$ evangelização, todo aprofundamento tem sua importância e necessidade, seja ele humano, espiritual, teológico, bíblico, doutrinal, litúrgico. Importante que se invista em todas as dimensões, que se dê oportunidade de 
aprofundamento ao discípulo para bem realizar sua missão. Exemplifiquemos com uma citação de Aparecida: ao falar da formação bíblica categoricamente afirma que "desconhecer a Escritura é desconhecer Jesus Cristo e renunciar a anunciá-lo" (DAp, 247). As modalidades formativas já existentes nas paróquias são muitas: cursos de teologia, cursos e estudos bíblicos, leitura orante da Palavra, círculos bíblicos, animação bíblica de todas as pastorais etc ${ }^{603}$. Decorrente das várias modalidades da formação, outra pergunta que possa surgir é formar para quê e em vista de quê, cuja resposta assume outros elementos, além do conteúdo. Entram em cena a criatividade, o senso crítico, a oração, nova mentalidade, a colegialidade, enfim, para a nova evangelização.

\subsubsection{1}

\section{Formar-se para formar: o desafio da formação inicial e permanente dos catequistas}

Posto isto, passaremos especificamente à formação dos catequistas, sem sombra de dúvida, um dos ministérios eclesiais centrais, cuja importância está sendo paulatinamente redescoberta.

A restauração do catecumenato traz sérias exigências, dentre as quais, e certamente a mais urgente, está na mudança de mentalidade de todos os agentes nele envolvidos. É dos catequistas o compromisso maior de entrar na nova lógica da iniciação, no acompanhamento catecumenal dos adultos ${ }^{604}$. Há de ressaltar que a consciência da necessidade da formação dos catequistas tem crescido nos

\footnotetext{
${ }^{603}$ Animação bíblica tem, dentre os muitos objetivos, formar os cristãos no conhecimento da Bíblia (VD, 73); conduzir a um maior conhecimento da Pessoa de Jesus Cristo (VD 73). Trata-se de formação e espiritualidade, conhecimento e alimento da Palavra. Não é mais uma pastoral, mas as pastorais que se alimentam da Palavra e a transmitem. É recolocar a bíblia no centro das atividades. “... Se incremente a pastoral bíblica, não em justaposição com outras formas da pastoral, mas como animação bíblica da pastoral inteira. Não se trata simplesmente de acrescentar qualquer encontro na paróquia ou diocese, mas de verificar que, nas atividades, nas associações e nos movimentos, se tenha realmente a peito o encontro pessoal com Cristo que se comunica a nós na sua Palavra". Bento XVI, Verbum Domini. São Paulo: Paulinas 2010, 194, n. 73. Devemos reconhecer que na Igreja no Brasil, a "pastoral bíblica" fez uma caminhada intensa e muito importante. Desde a $29^{\mathrm{a}}$ Assembléia Geral dos Bispos do Brasil, em 1991, quando a Dimensão Catequética passou a chamar-se de Dimensão "Bíblico catequética", os seguintes objetivos foram fortemente acentuados: valorizar a Palavra de Deus na Bíblia como fonte de vivência comunitária e da missão da Igreja" e "chamar toda a Igreja a fazer-se permanente ouvinte da Palavra de Deus, assimilando-a e confrontando-a com a vida" $\left(\mathrm{n}^{\circ} 90\right)$.

${ }^{604}$ Sobre a formação dos catequistas, sugerimos os seguintes subsídios: SANTOS, J. S. Formação de Catequistas para a iniciação à vida cristã. Terceira Semana Brasileira de Catequese. Edições CNBB; Formação iniciática de catequistas. Coleção de subsídios elaborados pela Sociedade de Catequetas Latino-Americana (SCALA).
} 
últimos anos, impulsionados por importantes documentos eclesiais, tais como a Catequese Renovada, o Diretório Nacional e Geral da Catequese ${ }^{605}$. Segundo o DGC, "o momento histórico em que vivemos, com seus valores e contra valores, desafios e mudanças, exige dos evangelizadores preparo, qualificação e atualização. Neste contexto, a formação catequética de homens e mulheres é prioridade absoluta" (DGC 234) ${ }^{606}$.

O desafio, contudo, é o como desta formação, e aqui nos referimos a um renovado processo formativo à luz e em coerência com o processo formativo catecumenal. Por vezes, dá-se mais prioridade a questões canônicas e doutrinais na formação e escolha de catequistas, ao passo que outras questões como a formação humana, a mentalidade, as motivações para assumir o ministério catequético ficam em segundo plano.

Optamos pelo termo formação inicial dos catequistas. A expressão pode soar estranha. Por que formação inicial quando se supõe que os catequistas já são iniciados? Reside aqui a problemática. O resgate do catecumenato é recente, o que significa que muitos dos atuais catequistas não conhecem e não foram formados no novo paradigma de iniciação cristã catecumenal. Apesar de toda boa vontade e doação à Igreja, nossos catequistas não foram formados na mentalidade catecumenal, para a qual se exige uma profunda formação, caso contrário, colocase em risco o futuro do catecumenato. Já expusemos a problemática da execução do catecumenato em determinados ambientes com a mentalidade de catequese tradicional, onde, apesar de receber o nome de iniciação cristã catecumenal, tratase do mero repasse de conteúdos. Mais do que falta de vontade dos catequistas,

${ }^{605}$ Vale lembrar que a catequese é hoje um ministério instituído na Igreja (Cf. DNC 80, 84,110$111,113,132,150,152-157,168,251 c, 180,286,317,331)$. "A catequese é um carisma, um dom e um ministério na Igreja. Ela requer dons especiais, talentos conferidos por Deus e cultivados durante a vida; é um ministério porque a missão que o catequista assume em forma de serviço á comunidade, provém de uma vocação, de um chamado. Ele o exerce em nome de Deus, da Igreja, da Comunidade". LIMA, L. A. Novos paradigmas para a Catequese no Brasil. In: Revista de Catequese. São Paulo: Unisal, v. 30, n. 117, janeiro/março, 2007, pp. 06-17.

${ }^{606}$ O Diretório Nacional da Catequese apresenta com clareza as principais características para os formadores dos catequistas da iniciação cristã: capacidade de ler as mudanças ocorridas na sociedade e saber atuar com otimismo e dinamismo evangélico; liberdade para orientar suas vidas e poder fazer escolhas importantes; abertura para fazer um caminho de fé respeitando os tempos com paciência e serenidade; capacidade de transmitir valores e experiência de vida; abertura constante ao aprendizado, capacidade de ser pai e filho, catequista e catequizando; saber narrar, contar histórias bíblicas, da comunidade e a própria historia de vida; instaurar constantemente um diálogo com o grupo e com a comunidade; saber utilizar uma pluralidade de linguagens; capacitar para o diálogo com outros cristãos e também com outras religiões e culturas; valorizar a gratuidade nas relações com o outro (DNC, 100-102). 
vale a pena enfatizar isto, a problemática parece estar na lacuna da formação catecumenal. Engana-se, contudo, quem pensa que basta o conhecimento teórico do RICA. Um dos desafios que o catecumenato enfrenta é formar catequistas não somente para a mas na proposta catecumenal. $\mathrm{O}$ catequista que durante vários anos exerceu o ministério nos moldes da catequese tradicional, não terá poucas dificuldades para entrar na nova proposta catequética.

Um prévio esclarecimento conceitual do termo 'educação' pode ajudar a melhor entender o assunto em questão. Historicamente, o termo formação esteve ligado à tarefa de 'educar através de impulsos extrínsecos', por meio de moldes, ou seja, de fora para dentro, do exterior para o interior. Sabemos dos limites dessa educação estritamente extrínseca, que não promove assimilação, conversão, envolvimento, afeto. Há uma não tão conhecida origem latina do termo que facilita a compreensão de uma diferente perspectiva de educação: a conjunção do prefixo ex (para fora, de dentro para fora) com o verbo ducare (conduzir, dirigir, levar para). Educare (ex-ducare, ex-dúcere) designa então o favorecimento do processo de desenvolvimento, crescimento, expansão, amadurecimento, aperfeiçoamento de alguém a partir do que ele já traz dentro de sim, em germe. A formação, portanto, há de assumir com equilíbrio as duas dimensões ou vertentes do processo educativo: cada pessoa é sujeito primeiro da própria educação, estimulada de dentro para fora ao aperfeiçoamento. Posto isto, a formação inicial catecumenal dos catequistas quer ser não tão pouco a recepção de conteúdos do RICA, ou tão somente questão de método e didática, ainda que esses sejam elementos imprescindíveis. As várias dimensões da formação dos catequistas, teológica, bíblica, pedagógica, dinâmica, didática conserva sua pertinência, desde que seja a partir de uma assimilação existencial, reflexiva, inteligente e orante dos elementos da fé cristã. Em termos mais precisos, formação e experiência de Jesus Cristo são termos afins, e vale, sobretudo, para os que conduzem o processo catecumenal. Estamos chamando a atenção para a urgência de uma formação catecumenal dos catequistas ao estilo catecumenal, isto é, promover-lhes um itinerário formativo progressivo, pautado nos mesmos elementos rituais e simbólicos pelos quais trilha o catecúmeno, capaz de conduzi-los ao aprofundamento da fé, à vivência mais conscientemente das riquezas da fé e dos 
sacramentos recebidos. O parágrafo abaixo, do Encontro Regional das Escolas Catequéticas resume a questão:

\begin{abstract}
Se os catequistas não são formados nessa visão iniciática da catequese, dificilmente depois, na ação catequética, irão adotá-la. Numa escola catequética, por exemplo, poderiam ser feitos alguns ritos de passagem. Dever-se-ia dar muita importância ao estudo e à vivencia dos gestos e símbolos. Uma vez que o catequista faz a experiência, poderá colocar em prática e repetir com naturalidade e inteireza na catequese. Nossas escolas precisam enfatizar a dimensão experiencial e ser menos 'conteudistas'. A forma celebrativa deve estar interligada com o conteudo ${ }^{607}$.
\end{abstract}

Os clássicos quatro pilares da educação, propostos pela UNESCO, em parte assumidos pelo DGC e pelo DNC, aprender a aprender, aprender a fazer, aprender a conviver, aprender a ser, lançam luzes para este particular ${ }^{608}$. Dois são, portanto, os objetivos da formação catecumenal dos catequistas: aprofundar a fé, introduzi-los no mistério, numa maior maturidade de fé, no mesmo mistério que eles irão conduzir outras pessoas, pois muitos dos nossos catequistas ainda vivem de uma fé herdada, trazem em sua iniciação cristã lacunas. E, em segundo lugar, intimamente relacionado ao primeiro, fazê-los conhecer-experimentar o processo catecumenal; apreender a ser, apreender a apreender, percorrendo ele mesmo na condição de catequista, a experiência catecumenal, a saborear os ritos e símbolos, a fazer em sua formação a interação conteúdo-liturgia, fé-vida. Com outras palavras, se os tradicionais 'cursinhos' preparatórios aos sacramentos (noivos, pais e padrinhos ...) estão com os dias contados, a tradicional formação de catequistas também está convocada a assumir um novo itinerário que integre conteúdo, mística, palavra, celebração, rito, experimento ${ }^{609}$. O mesmo se pede ao ministério do introdutor, cuja formação não pode ser negligenciada nem tão pouco basta um cursinho intensivo.

\title{
5.4.3.2
}

${ }^{607}$ Formação catecumenal nas escolas catequéticas - Encontro regional das Escolas Catequéticas - GRESCAT, p. 61. Texto revisto e editado por Pe. LIMA a partir do relatório elaborado por Margareth Villalba e Ir. Daniela Vasconcelos. In: Revista de Catequese. São Paulo: Unisal, ano 31, n. 124, outubro/dezembro, 2008.

${ }^{608}$ UNESCO: Educação, um tesouro a descobrir. Relatório Jacques Delors. São Paulo: Cortez MEC-UNESCO, 1998.

609 Iniciativas interessantes estão aos poucos se tornando realidade. Cf. SEGURA, M. A. J. Necessidade do Primeiro Anúncio na formação de catequistas. In: Revista de Catequese. São Paulo: Unisal, v. 29, n. 114, abril/junho, 2006 (pp. 28-33). 


\section{A formação inicial dos seminaristas e a formação permanente dos sacerdotes}

É no ministério sacerdotal onde mais se evidencia a necessidade da formação permanente, entendida como processo de contínua conversão e de aprofundamento e atualização nas áreas do saber humano, teológico, sociológico, pastoral, bíblico. No número 70 da Pastores Dabo Vobis podemos encontrar uma clara referência à importância da formação permanente no ministério sacerdotal:

Os padres sinodais tem exposto a razão que mostra a necessidade da formação permanente e que, ao mesmo tempo, descobre sua natureza profunda, considerando-a como fidelidade ao ministério sacerdotal e como processo de continua conversão ${ }^{610}$

Se a todos os agentes de pastoral são exigidas respostas à altura dos desafios culturais e religiosos, aos presbíteros, dado o forte símbolo religioso de que são portadores, o desafio apresenta-se ainda maior. Já se foi o tempo em que na paróquia o padre era um dos poucos que gozavam de formação superior ou teológica. Em muitas das paróquias frequentam pessoas com alto nível de formação nas mais diversas áreas, o que requer dos presbíteros maior preparo e atualização para dialogar de modo maduro com os diversos níveis de interlocutores, com as novas linguagens da sociedade global. Fato é que a nova realidade suscita novos acentos na configuração do perfil sacerdotal, como um homem 'do mundo' compenetrado com a cultura contemporânea, serenamente crítico com a realidade que se vive, sinceramente dialogante com o mundo cada vez mais democrático e pluralista, autenticamente humano de tal forma que nada do que lhe seja humano lhe seja alheio, profundamente espiritual como homem impulsionado pelo Espírito; um homem de misericórdia e compaixão, próximo dos pobres e servidor de todos ${ }^{611}$.

Torna-se evidente, portanto, o desafio da contínua formação presbiteral, capaz de fazê-lo ler os sinais dos tempos, de perguntar-se pela sua identidade presbiteral, pelo seu sadio lugar no conjunto dos ministérios eclesiais. "Somente

\footnotetext{
${ }^{610}$ Sobre a formação permanente dos presbíteros, confira as duas principais obras, uma nacional, da CNBB, o Documento 93, que traz as Diretrizes para a formação dos presbíteros no Brasil: CNBB. Diretrizes para a formação dos presbíteros na Igreja do Brasil (Documento da CNBB 93), Paulinas, São Paulo 2010; e outra, referência universal, a Exortação Apostólica Pos-sinodal Pastores Dabo Vobis.

${ }^{611}$ PINEDA. V. M. R. El compromiso misionero del Presbítero. In: Revista Medellín (teologia y pastoral para América latina), vol. XXXVI, n. 141. Enero-Marzo 2010, pp. 46-47.
} 
pessoas realmente amadurecidas podem viver e construir comunidades" ${ }^{\prime 612}$. Vale lembrar que a mudança de época atinge também o clero, provocando muitas vezes a crise da identidade sacerdotal, o que pode facilmente conduzir aos tão comuns quadros de carreirismo institucional, presbíteros high-tech, entre outras deturpações no exercício do ministério. O tornar-se adulto na fé, tão enfatizado ao longo da pesquisa, e o tornar-se adulto no ministério caminham juntos.

Outro aspecto nem sempre frisado com a devida necessidade diz respeito à formação dos seminaristas. Nas novas gerações dos presbíteros verifica-se uma acentuada tendência ao clericalismo, quando não fundamentalismo, haja vista a preocupação com rubricismo ou a ostentação vestuária. A indignação de Luiz Benedetti é provocativa:

A preocupação em festejar datas, ligadas à história pessoal no exercício do ministério, deixa em segundo plano, quando não são ignorados, os eventos importantes da comunidade. E tudo começa já no curso teológico: vestes e convites de ordenação. Legalistas, e quase sempre intransigentes, com o povo de Deus, são indulgentes para consigo mesmos ${ }^{613}$.

Continua Antoniazii: "a geração atual dos seminaristas (como parece, a dos jovens seus contemporâneos) não manifesta claros projetos de mudança e cuida mais da própria 'realização pessoal"',614.

Portanto, não podemos deixar de nos perguntar pelo modelo formativo daqueles que serão os futuros presbíteros e párocos à frente das paróquias. Em meio a uma série de questionamentos possíveis e legítimos, faz-se oportuno perguntar se o seminário, como a tradicional instituição formativa, a existência de uma teologia exclusiva para os candidatos ao sacerdócio, 'afastado' do mundo dos leigos, é o caminho mais adequado ${ }^{615}$ ? Dentre outras perguntas necessárias estão se a formação teológica é genuinamente espaço de reflexão crítica e sistemática, a partir de uma eclesiologia de comunhão, ou, antes, está caracterizado por um empirismo prático, pragmático? Qual o modelo eclesiológico subjacente aos

\footnotetext{
${ }^{612}$ MONTEOLIVA RAMOS, J. M. Felicidade humana e vida religiosa. São Paulo: Loyola, 1995, p. 34 .

${ }^{613}$ BENEDETTI, L. R. A mudança de época como desafio aos presbíteros. In: Revista Medellín (teologia y pastoral para América latina) Vol. XXXVI, n. 141. Enero-Marzo 2010 (p. 25-42), p. 32.

${ }^{614}$ CONFERÊNCIA NATIONAL DOS BISPOS DO BRASIL. Situação e vida dos seminaristas maiores no Brasil. (Estudos da CNBB, n. 74) Paulus: São Paulo, 1995, p. 37.

${ }^{615}$ BENEDETTI, L. R. A mudança de época como desafio aos presbíteros, op. cit., p. 32-33.
} 
seminários. Qual o perfil dos formadores? Qual o lugar da formação pastoral no projeto formativo? Seria a dimensão pastoral um apêndice ou o horizonte a perpassar todo o itinerário formativo? Qual o espaço de reflexão que é dado a tão séria questão da relação entre sacerdócio comum de todos os fiéis e sacerdócio ministerial? Enfim, como formar os futuros padres para uma vida simples, livres da tentação do poder, da ostentação e do capitalismo, aspectos esses típicos da cultura atual?

O que está em jogo é uma nova estrutura formativa das casas de formação (seminários). Sem avançar para águas mais profundas em nossa reflexão, importa perceber que assim como a estrutura formativa da iniciação à vida cristã está passando pelo processo de reestruturação, sintetizado no catecumenato, igualmente o modelo formativo dos candidatos ao sacerdócio parece urgir revisão. Lamentavelmente, já desde cedo assimilam que serão no futuro ministério sacerdotal responsáveis-proprietários de uma paróquia. O vocabulário em voga 'minha paróquia, 'minha diocese' deixa transparecer, inconscientemente ou não, certa mentalidade de superioridade, na qual tornam-se muito improváveis a abertura para o trabalho em equipe, a colegialidade e a descentralização. Portanto, a formação permanente dos presbíteros e a inicial dos seminaristas terá de ter como fio condutor o espírito de comunhão, uma nova relação com o conjunto dos interlocutores, não só da paróquia mas de toda a sociedade. Sem a necessária mudança de mentalidade dos presbíteros a estrutura paroquial dificilmente será alterada, pois essa é consequência daquela. Enfim, o que não é mais permitido é dar por aceito um modelo de sacerdote típico de outro momento histórico que não o de hoje. O que não é permitido é contentar-se com a formação recebida, ainda que de excelente qualidade, nos seminários no tempo da formação inicial.

\section{4 .4}

\section{Da ministerialidade do catecumenato a uma paróquia toda ministerial}

Abordada a formação permanente na paróquia, pretendemos pensar agora, à luz da ministerialidade do catecumenato, aos ministérios na paróquia. Bem sabemos da força evangelizadora dos leigos, sem os quais nenhum projeto pastoral conseguirá ir adiante. Contudo, qual o espaço que eles ocupam na paróquia, em termos de ministérios e serviços? Qual a compreensão que se tem da 
atuação dos leigos na ação evangelizadora paroquial? São ajudantes ou, antes, protagonistas, corresponsáveis pela missão?

\subsubsection{1}

\section{A ministerialidade do catecumenato}

Para levar a cabo o objetivo a que se propõe, o catecumenato dispõe de uma estrutura de ministérios e serviços, a partir de um projeto articulado de acompanhamento pessoal e coletivo ao longo de todo o processo da iniciação à vida cristã. Entram em cena, no itinerário catecumenal, uma diversidade de ministérios, serviços e carismas necessários à maturação da fé daquele que está no processo de tornar-se cristão.

O RICA oferece uma harmonia ministerial, na qual o catequista não é nem o único responsável nem o mais importante, ainda que lhe seja atribuído uma responsabilidade determinante. Para a dinâmica catecumenal, nenhum serviço é irrelevante ou encontra-se em segundo plano. Sejam os ministérios reconhecidos oficialmente pela Igreja (introdutor, catequista ...), sejam os ministérios ordenados, seja a presença da comunidade através da participação nos ritos catecumenais celebrativos, todos são constitutivos do processo da iniciação. Um exemplo pode ser buscado na própria estrutura do RICA: não se chega ao segundo momento catecumenal sem antes passar pelo pré-catecumenato, o que significa que o ministério do introdutor não é opcional, uma vez que o pré-catecumenato está diretamente sob a responsabilidade deste ministério.

O mesmo se pode dizer da participação da comunidade, a quem o Ritual confia uma atuação significativa, principalmente nos momentos litúrgicos marcantes da caminhada do iniciante, por meio das orações, do parecer, do exemplo de vida. Algumas passagens do Ritual da Iniciação ilustram o argumento: “... o povo de Deus, representado pela Igreja local, sempre compreenda e manifeste que a iniciação dos adultos é algo de seu e interessa a todos os batizados. (...) Deve, portanto, ajudar os candidatos e os catecúmenos durante todo o currículo da iniciação" (RICA, 41.); "quando possível compareçam às celebrações do catecumenato e tomem parte ativa nas respostas, orações, cantos e aclamações" (RICA, 41, 2; "No dia da eleição, visto tratar-se do crescimento da 
própria comunidade, procurem dar oportunamente uma opinião justa e prudente acerca dos candidatos" (RICA, 41, 3); "Na Quaresma, tempo da purificação e iluminação, sejam assíduos aos ritos dos escrutínios e das entregas e deem aos catecúmenos o exemplo de sua própria renovação no espírito de penitência, fé e caridade. Façam questão de renovar as promessa do Batismo na Vigília Pascal" (RICA, 41, 4); "No tempo da mistagogia participem das missas dos neófitos, procurem cercá-los de afeição e ajudá-los a se sentirem felizes na comunidade cristã" (RICA, 41, 5).

Do mesmo modo, o 'ministério' do padrinho-madrinha tem incidência direta no processo de quem está sendo iniciado na vida cristã. É ele quem acompanha o candidato no dia da eleição, na celebração dos sacramentos e no tempo da mistagogia; é sua função ensinar, auxiliar nas dúvidas e inquietações, e dar testemunho cristão e cuidar do progresso da vida batismal (cf. RICA, 43).

Com estas rápidas passagens, a conclusão a que chegamos é a de que se deve entender a metodologia catecumenal como uma estrutura ministerial em rede, no espírito da complementariedade e da interdependência. $\mathrm{O}$ ministério maior é a comunidade, na qual se encontram todos os serviços, carismas e ministérios. Nota-se que essa estruturação abre perspectiva para o tão difícil, mas urgente trabalho em conjunto, sobremaneira na atual realidade onde todas as frentes pastorais devem ser responsáveis pelo anúncio e reanúncio de Jesus Cristo. Abre perspectiva ainda para compreender a evangelização como processo, o que significa que pastorais, comunidades e movimentos somente serão evangelizadores à medida que estiverem concatenadas entre si em busca do mesmo objetivo.

Para Boróbio, o catecumenato é um 'potencialização dos ministérios da Igreja', neles encontram-se várias dimensões da missão de toda a Igreja ${ }^{616}$. Floristán, por sua vez, enriquece a reflexão com a expressão 'padrinhado comunitário' para se referir à riqueza ministerial contida no $\mathrm{RICA}^{617}$. Continua a autor:

\footnotetext{
${ }^{616}$ Cf. BOROBIO, D. Catecumenato e iniciación Cristiana: um desafio para la iglesia hoy. Barcelona: Centre de Pastoral Litúrgica, 2007 (biblioteca litúrgica, 30), p. 78.

${ }^{617}$ FLORISTAN, C. Catecumenato: história e pastoral da iniciação, op. cit., p. 231-234.
} 
Neste Ritual se dá grande importância à comunidade. É ela que acolhe, acompanha, avalia, admite, anuncia e celebra a salvação oferecida por Deus em Cristo a cada um dos candidatos. Também é colocado em relevo seu caráter ministerial, ao admitir uma série de serviços de iniciação que revela a pluralidade compartilhada da responsabilidade pastoral da iniciação ${ }^{618}$.

Se é inquestionável a proposta de variedade de serviços, carismas, ministérios catecumenais, necessários à tarefa da iniciação à vida cristã, a questão torna-se problemática quando confrontamos o quadro acima desenhado com a real situação ministerial paroquial na qual o catecumenato é realizado. Para problematizar a questão, algumas perguntas podem auxiliar a questão em voga: a comunidade paroquial, hoje, é madura o suficiente ministerial e missionariamente para acompanhar o candidato à vida cristã, como idealiza a metodologia catecumenal? O RICA supõe uma densa consciência ministerial e participativa da comunidade, o 'ministério coletivo', conforme já recordado, isto é, a participação de toda a comunidade de fé nos ritos, no parecer e na aprovação do candidato, entre outras formas de atuação. Trata-se de uma realidade ou de uma meta? A resposta parece óbvia se olharmos a atual conjuntura litúrgica das paróquias, sobretudo as paróquias de massa, nas quais uma maioria absoluta, na passividade, 'assiste à celebração'. O número ideal de introdutores, tantos quanto forem o númeor de catecúmenos, requerido pelo RICA, na esteia do acompanhamento personalizado, na realidade contrasta com a escassez de agentes nas comunidades eclesiais.

Estas e outras questões são indicadoras da dificuldade de uma efetiva prática catecumenal, consequência, certamente, de uma deficitária estrutura ministerial paroquial. Não é difícil perceber que entre o modelo idealizado pelo RICA e a atual realidade paroquial paira uma distância, a qual não será desfeita, caso não haja uma reestruturação ministerial no conjunto paroquial. Importa a pergunta: o que a ministerialidade catecumenal diz ao processo de renovação paroquial, e esta àquela?

Algumas afirmações a seguir, quase que antecipadas tentativas de respostas a estas questões, serão norteadoras da reflexão dos itens que seguirão logo após.

\footnotetext{
${ }^{618}$ Ibid., p. 170.
} 
1. A rede de ministérios do catecumenato, a partir do trabalho em conjunto e articulado, a consciência ministerial, expressa na ativa participação da comunidade nos ritos e celebrações, como condição para a concretização do processo catecumenal, é muito mais uma realidade a ser construída do que algo já existente na configuração paroquial. Trata-se muito mais fruto de uma Igreja adulta, toda ministerial, a ser conquistada e construída do que ponto de partida. A variedade de ministérios à disposição da iniciação cristã catecumenal será uma realidade à media que a paróquia suscitar lideranças, delegar responsabilidades e serviços. Portanto, aquilo que o RICA concebe como modelo de comunidade ministerial, conscientiza, questiona, provoca e motiva a renovação ministerial paroquial.

2. Neste processo dialético, ainda que a nova consciência ministerial não seja o ponto de partida, e sim realidade eclesial a ser conquistada, à medida que a comunidade participa, ainda que timidamente da vida e acompanhamento dos catecúmenos, ela mesma desperta para a consciência missionária e ministerial. $\mathrm{Na}$ proposta do Ritual, portanto, ao supor o consciente envolvimento da comunidade no processo de iniciação cristã do catecúmeno, encontra-se aí um potencial para despertar a comunidade à missionariedade e à ministerialidade. Nesta perspectiva, a pessoa descobre sua responsabilidade na Igreja quando começa a exercê-la. A comunidade amadurece quando recebe atribuições e é incumbida de funções.

3. Ao perceber que a paróquia é ou está se tornando uma realidade ministerial, o catecúmeno estará mais disposto a assumir tão logo um serviço eclesial. O modelo de Igreja que ele encontra é o que ele vai assimilar em sua vida religiosa. Os catecúmenos de hoje serão os ministros de amanhã, desde que sejam iniciados numa e a partir de uma comunidade ministerial.

4. A qualidade da iniciação à vida cristã é condição para o futuro ministerial da paróquia, ou seja, quando não iniciados devidamente à vida cristã, quando são portadores de uma fé imatura, dificilmente assumirão ministérios e serviços eclesiais, além do que nem sempre quem os assume o faz para a edificação da Igreja e a serviço das pessoas, mas por vezes em nome da vaidade pessoal.

\subsubsection{2}




\section{A estrutura ministerial da paróquia questionada}

O dilema acima exposto - ministérios do catecumenato e a real ministerialidade paroquial - evidenciou a necessidade de debruçar sobre a configuração ministerial na paróquia, no intuito de melhor detectar os limites e apontar possíveis caminhos. Trata-se de uma exigência advinda da natureza missionária da Igreja. Uma paróquia que não investe em ministérios e nos leigos anula rigorosamente seu potencial missionário. Se as atuais dificuldades em transmitir a fé não são poucas, a problemática torna-se infinitamente maior quando a Igreja se depara no seu próprio interior com uma estrutura que não a favorece tal missão.

Outra razão que justifica a importância da reflexão do tema em questão para a renovação paroquial está no fato dela, a paróquia, depender muito do rosto do padre, isto é, a realidade das paróquias é excessivamente dependente da mentalidade, estilo, objetivos, eclesiologia dos padres. Lembro-me de uma das frases ditas certa ocasião por um leigo engajado. "A paróquia é igual a uma prefeitura: quando muda o padre é como quando muda o prefeito; cada um faz o que quer, sem levar em conta a caminhada já feita”. A aguda percepção deste fiel denuncia a falta de um plano de pastoral, faz questionar a estrutura ministerial paroquial, obriga-nos a repensar a relação paróquia-clero, leigo-clero, a relação ministro ordenados-ministérios laicais, a sinodalidade, o lugar-identidade do ministro ordenado, a promoção de novos ministérios e serviços, oficialmente reconhecidos pela Igreja local, e tantas outras questões que por si só mereceriam um debate aprofundado. Falar de nova estrutura ministerial significa, portanto, entrar num campo por demais amplo.

Quando se recorre aos evangelhos para justificar um modelo ministerial de comunidade deixado por Jesus, tende-se a buscá-lo na formação dos doze, os quais foram encarregados de pregar, batizar, formar comunidades. Segundo esse modelo, resulta que a intenção fundamental de Cristo teria sido antes construir a hierarquia, e a partir dela, a comunidade, compreensão esta, hoje, insustentável. É sabido pelos trabalhos da exegese moderna que a referência aos doze é símbolo e prefiguração das doze tribos de Israel, que por sua vez prefiguram a plenitude do novo Povo de Deus. Não se trata de anular a missão especial dos doze, mas entê- 
la a partir da comunidade ${ }^{619}$. Além do que, parece não ser um bom método estudar a origem da Igreja somente a partir dos evangelhos, sem levar em conta outros escritos do Novo Testamento, mais antigos que a redação evangélica. Em outros escritos do NT é possível encontrar uma estruturação de Igreja muito mais variada e diversificada ${ }^{620}$.

O que queremos chamar a atenção é que no Novo testamento não encontramos um único modelo ou estrutura ministerial para as comunidades, e nem muito menos um modelo entregue por Jesus ou pelos apóstolos. Encontramos, ao contrário, diversos exemplos de como foram se estruturando as diversas comunidades, como resposta às necessidades do momento histórico ${ }^{621}$. Nesta perspectiva, mais importante do que desenhar uma estrutura ministerial para a paróquia é garantir certos princípios para o bem da comunidade. Sem sombra de dúvida, o primeiro e central princípio é assumir a centralidade da comunidade. É ela o ministério principal, a partir da qual os serviços e ministérios específicos tem sua razão de ser, por expressam a ação de Deus e a ação da comunidade. Vale apena insistir nesta questão, uma vez que sem esta clareza torna-se inviável qualquer tentativa de avanço na reflexão e prática dos ministérios eclesiais.

\subsubsection{3}

\section{A necessária passagem do binômio ‘clero-leigo' para 'comunidade- carismas e ministérios'}

A mudança eclesiológica promovida pelo Concílio Vaticano II é decisiva no que tange à concepção da comunidade como Povo de Deus, profético, ministerial e missionário, rompendo assim com a ideia de serem os fiéis simples destinatários da missão. Igreja é, antes de tudo, povo de Deus, daí a comum condição de todos os batizados, tanto na dignidade como no agir (LG 32) ${ }^{622}$.

\footnotetext{
619 “ não se trata de colocar em dúvida a missão especial dos doze na estruturação original de igreja. Se trata, melhor, de compreender que os apóstolos (e por eles, a hierarquia) não são anteriores e exteriores a Igreja. Quer dizer, o primário e fundamental não é a hierarquia, ao que logo se soma o povo; senão que o primário é o povo de Deus, em sua totalidade, na qual a hierarquia tem um papel e uma função especial. Porem só uma função de serviço, dentro de uma totalidade maior, a comunidade toda inteira". CASTILLO, Los ministerios em la Iglesia: de uma valoración 'clerical' a uma instancia comunitária, op. cit., p. 20.

${ }^{620}$ Ibid., op. cit., p. 20.

${ }^{621}$ Cf. BOROBIO, D. Comunidad eclesial y ministerios. In: Phase. Revista de Pastoral Liturgica. Barcelona, v. 38, fasc. 228, 1998, p. 480.

622 A missionariedade alicerçada sob o fundamento do batismo é aceito sem dificuldades, ao menos pelos documentos eclesiais. Pelo batismo todo cristão é convocado à missão, a assumir sua
} 
Contudo, ainda que a relação ministro ordenado e não ordenado seja uma relação 'pacífica', sem conflito, não significa uma relação de adultos. O Povo de Deus se edifica com a participação de todos, cada um de acordo com sua função e estado, caso contrário se está formando cristãos infantiz, incapazes de tomar decisões, e quando sentem que há outra oferta melhor, deixam a comunidade, porque têm sido clientes e não parte da comunidade eclesial. Nesta perspectiva, com muita propriedade afirma Francisco, "o fenômeno do clericalismo explica em grande parte, a falta de maturidade e de liberdade cristã em parte do laicato da América Latina"623.

O ponto de partida para afirmar a possibilidade de uma diferente estrutura de ministérios tem como exigência irrenunciável repensar o binômio 'sacerdoteleigo' ou 'hierarquia-laicato', cuja mentalidade legitima uma relação de desiguais. Em absoluto, não se trata do não reconhecimento do valor ou da necessidade do ministério ordenado, essencial para a existência de comunidades cristãs, pois ministros ordenados são constitutivos da comunidade cristã. O que está em cheque é a relação entre clero e leigo que daí resulta, ou mais especificamente, a relação entre ministério ordenado e o conjunto da comunidade. Importante que se diga que os ministérios são da comunidade, e não o contrário. Consequência disto é o fato dos ordenados não estarem autorizados a se colocarem acima ou fora da comunidade, mas no interior da mesma. Compreender o ministério ordenado acima da comunidade remete à compreensão católica clássica, na qual o ministério tem prioridade sobre ela, por ser o sacramento da ordem uma vontade direta de Cristo, sendo por isso ele, o ordenado, um 'alter Christus'. Importante que se diga que não se está questionando a dimensão ontológica do sacerdócio, mas as questões pastorais, jurídicas e ideológicas resultantes daí para a comunidade eclesial. Antes de tudo, o presbítero precisa ver-se como membro de

condição de cristão através de um serviço eclesial. A partir do resgate do caráter unitário dos três sacramentos da iniciação crista catecumenal, pode e deve ser mais enfatizada a iniciação cristã, realizada sacramentalmente, como alicerce do mandato missionário e ministerial de todo cristão. Reside, portanto, nos sacramentos da iniciação e não somente no batismo, a igualdade entre os diversos ministérios e funções, através dos quais todos são sacerdotes, reis e profetas. Sacramentos da iniciação cristã e ministérios estão, portanto, numa relação muito íntima. Em tempos de investimento no catecumenato, pode ser esta uma chave de leitura para avançar na questão ministerial na Igreja.

${ }^{623}$ PAPA FRANCISCO. Mensagem e homilia - JMJ Rio 2103, p. 94. 
um presbitério, de uma comunidade com a qual condivide a comum missão ${ }^{624}$. Lamentavelmente, a constatação feita sem dificuldades é que a paróquia é excessivamente dependente do padre.

Neste sentido, o binômio necessário para que se afirme uma diferente configuração ministerial é aquele denominado 'comunidade-ministérios ${ }^{625}$, ou 'comunidade-carismas e ministérios', o qual realça a correta relação entre os dois termos em jogo, comunidade-ministérios, consequentemente, a sadia relação ministros ordenados e ministérios laicais. Esta tem sido a intuição já presente no Vaticano II, explicitadas por vários teólogos, com destaque para Congar.

Não se trata apenas de mudança de nomeclatura, mas das relações estabelecidas a partir dela. No paradigma comunidade-ministério o acento está na comunidade e na rede de ministérios de que ela é portadora. Sinal de Deus num lugar é a comunidade e não o clero ${ }^{626}$. O centro não são os ministérios ordenados, nem os não ordenados, mas o tecido comunitário, dentro do qual todos os ministérios e serviços tem sentido de ser. A forma de ser de uma comunidade só pode ser ministerial, ao passo que conceber a paróquia a partir da relação sacerdote-leigo acentua o que separa e divide, antes do que une a Igreja. Seja na teoria ou na prática, claramente se percebe que no binômio em voga o acento é colocado na hierarquia e não na comunidade ${ }^{627}$. Prova disto é que para a maioria, exceto a um grupo mais consciente de sua missão, paróquia é sinônimo de pároco, e Igreja, de padres. O empobrecimento eclesial daí decorrente, o fraco sentimento de pertença e corresponsabilidade dificultam a construção de comunidades adultas. A mesma reflexão pode ser encontrada no já mencionado documento da CNBB, Missão e ministérios dos cristãos leigos e leigas. Ao falar da estrutura social da Igreja o documento assim de expressa

... essa estrutura continua ainda sendo pensada dentro do binômio clássico 'hierarquia e laicato'. É sabido, porém, que esse binômio - que condiciona fortemente o nosso modo de entender e de viver a realidade eclesial e a missão não é suficiente. De um lado, distingue muito; de outro lado, distingue muito

\footnotetext{
${ }^{624}$ BRAMBILLA, F. G. La parrocchia oggi e domani, op. cit., pp. 200-201.

625 A diferença entre um esquema e outro marca o pensamento de Congar. Cf. Ministères et communion eclésiale. Paris-Cerf, 1971. Na edição casteliana: Ministérios y comunión eclesial. Fax: Madrid.

626 BORRAS, A. Aspectos teológicos e canônicos da remodelação paroquial, op. cit. In. BORRAS, A.; ROUTHIER, G. A Nova paróquia, op. cit.; p. 144.

${ }^{627}$ CASTILHO, J. M. Los ministerios en la Iglesia, op. cit., p. 17.
} 
pouco! Expliquemo-nos. O binômio distingue muito a hierarquia e o laicato porque não realça suficientemente a unidade batismal, crismal e eucarística que liga no mesmo e único Espírito os leigos e os ministros ordenados ... De outro lado, o binômio distingue muito pouco, porque, no interior da comunhão eclesial, destaca apenas estas duas realidades - a hierarquia e o laicato - deixando na sombra a imensa variedade de carismas, serviços e ministérios que o único Espírito suscita para a vida e a missão da Igreja ${ }^{628}$.

O principio norteador da ministerialidade paroquial, portanto, não pode ser o binômio clero-leigo, mas a realidade teológica dos sacramentos da iniciação à vida cristã. Em outras palavras, o sacerdócio comum de todos os fiéis é condição para a existência de uma pluriministerialidade.

\subsubsection{4}

\section{Laicato: 'ajuda' ou corresponsabilidade?}

Em consonância com a reflexão acima, outro binômio que necessita de revisão diz respeito à compreensão que se tem da atuação dos leigos e leigas na paróquia. Aquela diferença entre sociedade x comunidade da qual discutíamos no capítulo precedente reaparece na questão ministerial. Uma estrutura onde o clero constitui o grupo dominante que assegura os serviços religiosos aos demais, e os leigos que são a maioria absoluta formam o grupo que obedece e executa, assemelha-se mais à sociedade do que à comunidade. $\mathrm{O}$ exagero nas palavras tem o propósito de chamar a atenção para o que é uma tendência, e porque não dizer, uma realidade em muitas paróquias. $\mathrm{O}$ dilema em questão pode ser encontrado na estrutura canônica, legitimado pelo Código de Direito, conforme pode ser lido nos cânones $519^{629}$.

\footnotetext{
${ }^{628}$ CONFERÊNCIA NACIONAL DOS BISPOS DO BRASIL. Missão e ministérios dos cristãos leigos, op. cit. n. 104.

629 "O poder do clero está inscrito no Código de Direito Canônico. Este deriva do direito romano, no sentido de que define os poderes na Igreja (99\% dos cânones). Há outras acepções do direito, concepções que prevaleceram em todas as sociedades não-imperiais, não ditatoriais: o direito define as liberdades e os direitos. Precisamos de um novo direito, se quisermos entrar num novo projeto de Igreja no mundo atual. Precisamos de um direito que proteja os fracos e limite os fortes, proteja os leigos e limite os poderes do clero. A estrutura atual do Direito Canônico infantiliza os leitos. Forma pessoas submissas, sem pensamento próprio, tímidas, sem combatividade, sem iniciativa, sem preparação para o diálogo ou a deliberações, com o resultado de que não provocam conversões. Há exceções, porque há sempre algumas pessoas que conseguem dominar o sistema. Mas a maioria entra no sistema e dentro do sistema é muito difícil chegar ao amadurecimento espiritual”. COMBLIN, J. Olhando para o horizonte. In: Revista Eclesiástica Brasileira, v. 65, n. 260,2005 , p. 854.
} 
Pároco é o pastor próprio da paróquia que lhe é confiada, exerce o cuidado pastoral da comunidade que lhe foi entregue sob a autoridade do bispo diocesano, em cujo ministério de Cristo foi chamado a participar, para que nesta mesma comunidade cumpra as funções de ensinar, santificar e reger, com a colaboração também de outros presbíteros ou diáconos, e com a ajuda dos fiéis leigos.

Enquanto que a relação entre presbíteros e diáconos, portanto, entre o clero, situa-se no horizonte da coresponsabilidade, a relação entre clero-leigo é concebida como ajuda. A pergunta central a ser feita é se a participação ativa, consciente, responsável e generosa dos leigos, tão bem entendida na metodologia do RICA, trata-se tão somente de ajuda ao clero, ou antes, aponta para a relação comunidade-ministérios e carismas na qual todos, a partir de própria função, formam o grande ministério coletivo, denominado paróquia? O que à primeira vista pode parecer apenas questão terminológica, ajuda x corresponsabilidade, revela a distância entre uma realidade ministerial, onde o próprio Espírito dota a todos de dons e carismas específicos, em vista do bem comum, numa relação de igualdade, e um modelo regido pela relação de ajuda, na qual uma parcela detém nas mãos a decisão, podendo contar, no entanto, com a ajuda quando necessário. Ajuda situa-se no horizonte da permissão, da autorização quando se é solicitado, ao passo que corresponsabilidade é fundamentalmente compromisso, por isso mesmo, a identidade da comunidade.

Um exemplo típico desta compreensão encontramos nos assim chamados ministérios de 'suplência', que são aqueles que embora sua atuação não dependa da ordenação, as funções neles implicados historicamente são consideradas próprias do ministério ordenado. Desta forma, quando um leigo o assume está fazendo por falta ou impossibilidade dos ministros ordenados. É o caso dos ministros extraordinários do batismo e da eucaristia. A questão que se coloca é

Se estas funções, embora próprias e típicas do ministério ordenado, podem, em determinadas circunstâncias, ser assumidas por leigos e leigas, por que não se pensar numa reorganização mais ousada dos ministérios eclesiais, criando verdadeiros e próprios 'ofícios' a serem conferidos a leigos e leigas estavelmente e com responsabilidade própria e não simplesmente com 'suplência'? Do ponto de vista teológico, se um leigo ou leiga pode suprir o ministro ordenado em determinadas ações, significa que está habilitado para tanto, em virtude dos sacramentos de iniciação ${ }^{630}$.

${ }^{630}$ CONFERÊNCIA NACIONAL DOS BISPOS DO BRASIL. Missão e ministérios dos cristãos leigos, op. cit., n. 89. 
Mais do que colaboradores, a vocação cristã está na corresponsabilidade eclesial. Em outras palavras, o fiel não é aquele que dá uma 'mão', mas alguém que é chamado a pensar junto e a caminhar dentro de comum um projeto pastoral $^{631}$. O que não se pode é considerar o padre como o único adulto de direito na comunidade, o único dotado do múnus pastoral. Enquanto não se der espaços à novas iniciativas e quebrar o paradigma em voga será sempre limitada a consciência de ser comunidade-Igreja. A paróquia gira em torno dos padres. Vigora ainda uma instituição medieval, hierárquica, de cima para baixo, de caráter centrípeto, uma organização de 'domínio-dependência', autoridade-obediência', 'senhor-súdito', 'sacerdote-fiéis' ${ }^{632}$. "A questão maior gira ao redor do eixo cleroleigos: passar de uma concentração de responsabilidade nas mãos do clero (uns poucos) para a multiplicidade de serviços organicamente coordenados" $" 633$.

A reclamação de Comblin é pertinente. "A igreja na cidade morre por falta de confiança e liberdade. Há milhares de pessoas dispostas a serem missionários, pastores, fundadores de comunidades e Igrejas, mas não recebem permissão" ${ }^{\text {"634 }}$. Se o autor deixa transparecer um certo tom de generalização, não nos é permitido negar que em muitas realidades paroquiais são os párocos e bispos que determinam, de acordo com sua mentalidade, o grau de ministerialidade de cada paróquia e diocese. O que nem sempre está clara é a identidade da paróquia naquele lugar, ou seja, uma presença eclesial encarnada, que não dependa unicamente da cabeça do pároco ou do bispo mas que consciente de sua missão naquele lugar, trabalhe numa rede de serviços e ministérios.

\subsubsection{5}

\section{Antes de novos ministérios, um ministério novo: repensando o modelo sacerdotal cultual em prol da figura ministerial do presbítero}

Posto os novos binômios por onde devem trilhar a relação da ação evangelizadora paroquial, inclui-se na agenda da reconfiguração ministerial

${ }^{631}$ Cf. SORAVITO, L.; BRESSAN L. Il Rinnovamento della parrocchia in uma società che cambia, op. cit., p. 157.

${ }^{632}$ Cf. CALDENTEY, J. Significado das Comunidades Cristãs de Base para a Igreja. In: Concilium: Revista Internacional de Teologia. Petrópolis: Vozes, v. 11, fasc. 104, 1975, p. 87.

${ }^{633}$ ALMEIDA, D. B. A pastoral na virada do milênio. In: CALAMAN (org.). A sedução do sagrado, op. cit., p. 181.

${ }^{634}$ COMBLIN, J. Nota a propósito de Igreja e sociedade urbana: In: Urbanização e evangelização. Porto Alegre: Cadernos da ESTEF - 5, p. 57. 
paroquial a revisão da identidade-missão-lugar do ministério presbiteral. Referimo-nos à insistência na manutenção do modelo cultual e sacral do sacerdócio voltado tão somente ao culto. Se anteriormente foram questionadas a relação ajuda-correponsabilidade, clero-leigo, aqui entra em debate a identificação sacerdócio-culto, a qual mais uma vez reforça o sacerdote como alguém acima da comunidade ou separado dela.

Análises eclesiológicas têm nos mostrados as várias vertentes, tendências, modelos, perfis de sacerdotes ${ }^{635}$. Fato é que o modelo denominado 'cultual' tem sido, senão o predominante, aquele que está enraizado na estrutura ministerial sacerdotal, ou mais especificamente, enraizado consciente ou inconscientemente na identidade do sacerdócio, o que incide diretamente na compreensão e no realizar sua missão.

Apresentaremos a seguir alguns perfis, que na prática se resumem em dois - o cultual e o modelo ministerial, ainda que em análises distintas, abordadas por diferentes estudiosos no assunto. Cozzens ${ }^{636}$ apresenta dois modelos de padre, o do 'servo-líder' e o 'modelo cultual'. Para o autor, o modelo cultual é o que se impõe na atualidade. Até o Vaticano II esse foi o modelo predominante, e hoje retorna com força. Neste modelo, o sacerdócio é o homem sagrado, dedicado às dimensões sacramentais e litúrgicas. É ele alguém separado. "Centrado no poder de ministrar os sacramentos, sobretudo a eucaristia, o padre tem um estilo individualista no ministério. O modelo cultual enfatiza o poder sacramemental único do sacerdote" 637 . Prevalece, portanto, a ação ad intra, voltada para o culto, para o burocrático e para o funcionalismo, ou nos termos de Aparecida, para a manutenção pastoral.

Já no modelo ‘servo-líder', estabelece-se uma relação com o fiéis de lídercompanheiro, pois sabe e se está convencido da igualdade e dignidade fundamental entre todos pelo batismo. "Ele enfatiza a participação, a corresponsabilidade e o diálogo na condução da vida eclesial. Como "portador do

635 "Partimos de uma constatação de fato, embora estejamos conscientes de que é único o sacerdócio de Cristo, há hoje no Brasil uma variedade de modelos de presbíteros. São tantos os modelos quanto as eclesiologias existentes na prática". BENELLI, S. J. Modelos de presbítero no contexto católico. In: Fragmentos de Cultura. Goiânia, v. 19, n. 5/6, p. 378.

${ }^{636}$ COZZENS, D. B. A face mutante do sacerdócio: reflexão sobre a crise da alma do sacerdote. São Paulo: Loyola, 2001.

${ }^{637}$ BENELLI, S. J. Modelos de presbítero no contexto católico, op. cit. In: Fragmentos de Cultura, Goiânia, v. 19, n. 5/6, op. cit., p. 371. 
mistério', sua tarefa é introduzir e iniciar as pessoas no mistério de Deus, ele é o 'mistagogo",638. Importa perceber a relação entre esse perfil sacerdotal, proposto pelo autor, e o mistagogo do processo catecumenal, aquele que conduz ao Mistério. Ambos, o servo líder da paróquia e o mistagogo do catecumenato caminham juntos com o fiel; ambos se colocam numa relação fraterna e serviçal, e se encontram no caminho do discipulado.

$\mathrm{Na}$ mesma perspectiva, Lorscheider ao analisar os modelos sacerdotais oferece valiosa contribuição na busca de um novo perfil de padre, em sintonia com a eclesiologia do Povo de Deus, na harmoniosa relação entre o sacerdócio comum de todo batizado e o ministerial ordenado. Para o autor, há duas visões eclesiológicas de sacerdote, ‘hierarquia-laicato’ e Igreja Povo de Deus. Uma visão que acentua mais o lado institucional da Igreja, voltada mais ação ad intra, à administração dos sacramentos, pois interessa salvar os fiéis com os sacramentos. Já no perfil sacerdotal Povo de Deus, há uma consciência mais clara de igreja fermento, serviço, povo; é uma igreja missionária, onde os cristãos sabem de sua responsabilidade política. "É a Igreja com forte participação do povo nas decisões pastorais" $" 639$.

Também Antoniazzi enriquece a reflexão. Segundo ele, há a 'dedução cristológica' e a 'fundamentação eclesiológica'. Numa primeira perspectiva 'o presbítero ou sacerdote é visto exclusivamente como 'alter Christus', figura e sacramento de Cristo diante da comunidade. Nesta visão, o presbítero corre o perigo de se considerar anterior à comunidade da Igreja (que nasce do esquema: Cristo - apóstolos bispos - presbíteros - fiéis), com graves consequências pastorais: dissociação da Igreja local, desqualificação religiosa dos leigos, escassa inculturação, involuntário incremento da secularização da sociedade. Na visão eclesiológica, a Igreja nasce da missão do Filho, Jesus Cristo e do Espírito Santo, que fundam a Igreja pela Palavra e pelos sacramentos, de um lado, como também pela graça e pelos carismas, por outro. E é dentro da igreja, comunidade de fé que,

\footnotetext{
${ }^{638}$ Ibid., p. 371.

${ }^{639}$ LORSCHEIDER, A. O perfil espiritual e pastoral do presbítero hoje. In: Revista Eclesiastica Brasileira, v. 62, n. 246, abril/junho 2002, p. 300.
} 
entre os diversos ministérios, o ministério ordenado continua o ministério apostólica, para manifestar a unidade da fé em Cristo"640.

A observação de Taborda é iluminadora nesta questão. Em seu livro $A$ igreja e seus ministros ele constrói uma teologia dos ministérios onde mostra que a concepção pneumatológico-eclesial do primeiro milênio contribui para um modelo de ministro ordnenado muito mais ligado a uma comunidade concreta e no compromisso com os irmãos e irmãs, ao passo que a teologia cristológicoindividualista do segundo milênio concebe o ministério ordenado para a Igreja e não mais na Igreja $^{641}$.

É importante que se diga que esforço em recuperar a identidade e o lugar do ministério ordenado, mais particularmente do presbítero, encontra espaço no Concílio Vaticano II. Duas são as referências fundamentais para esta releitura: Presbyterorum ordinis, 2 e Lumen Gentium, 28. Sem rejeitar totalmente a dimensão do culto e da consagração, o acento da instituição do presbirato está não em um momento pontual, na última ceia, no 'hoc facite in meam commemorationem' (Lc 22,20), conforme concebia a visão pré-conciliar, mas na totalidade da missão de anúncio-santificação-pastoreio "É na inteira missão apostólica recebida de Jesus, antes e depois da páscoa (missão que continua aquela que Jesus recebeu do Pai), que deve ser localizada a instituição do ministério ordenado e, portanto, do presbiterado" ${ }^{642}$. Enquanto que o modelo cultual reduz o ministério ao culto, aos moldes do sacerdócio levítico, o modelo presbiteral situa o ministério na missão de Jesus. Não se trata mais de fundar o ministério sacerdotal num momento pontual, o da última ceia, que lhe dá o poder sacerdotal de consagrar a eucaristia, mas a missão do anúncio, celebração e guia da comunidade.

No modelo sacral ou cultual a ordenação confere ao ordenado uma 'dignidade' superior, dotado de maior 'santidade'. Neste modelo pré-conciliar a natureza 'cultual-sacrifical do sacerdócio judaico prevalece sobre a natureza 'diaconal' do ministério cristão, tendência constatada já a partir dos primeiros

\footnotetext{
${ }^{640}$ ANTONIAZZI. Uma leitura teológico-pastoral. In: Valle, E. (org.). Padre: você é feliz? Uma sondagem psicossocial sobre a realização pessoal dos presbíteros do Brasil. Brasília: CNBB; CNP; Loyola, 2003, p. 118-142, pp. 118-120.

${ }^{641}$ Cf. TABORDA, F. Igreja e seus ministros. São Paulo: Paulus, 2011, pp. 107-133.

${ }^{642}$ CASTELLUCCI, Il ministero ordinato, op., cit., p. 238.
} 
séculos do cristianismo ${ }^{643}$. Já no modelo ministerial, a ordenação é um serviço, como bem podemos ler na Lumen Gentium, ao refletir sobre o episcopado. Para o documento, não se trata de uma 'dignidade, e sim um verdadeiro 'serviço', no conjunto da variedade de ministérios que o Senhor institui na Igreja 'para o bem do todo o Corpo' (cf. LG, 18 a). Torna-se evidente a renúncia à interpretação de dignidade, honra, em prol da diaconia e do serviço.

\subsubsection{6}

\section{Presbítero, homem de comunhão eclesial}

No paradigma de paróquia tridentina, caracterizada pela 'cura animarum', estava claramente definida a identidade e função do presbítero. Tratava-se da figura clássica do padre, marcada por uma relação vertical-individual com os fiéis, com ênfase na cura de almas do que na formação de uma comunidade ${ }^{644}$. A partir de uma relação dever-obrigação, relação vertical e individualista, mais importante do que formação e cuidado da comunidade estava a cura de almas. Importa perceber que a questão de fundo é a qualidade da relação entre ministro e comunidade. Se está de certa forma nítida a função do presbítero na 'cura animarum', torna-se sempre mais urgente a pergunta pela cura da comunidade. $\mathrm{O}$ que se entende com a afirmação de que o 'pároco pastor próprio da comunidade (can. 519)? O que significa 'o cuidado pastoral da comunidade' (can. 519)? ${ }^{645}$

A passagem do modelo sacral-cultual, acima visto, para o missionárioministerial, cuja ênfase é colocada não no poder da ordem mas na natureza missionária do presbítero, vem em boa hora. Se assumida pelos presbíteros, a paróquia terá vantajosas chances de ganhar novo rosto institucional. Nesta perspectiva, propomos o ministério do presbítero como ministério horizontal, que passa muito mais pela formação, cuidado e serviço às comunidades, sem desconsiderar o atendimento pessoal, o qual também passará pela relação horizontal, entre irmãos. Urge na renovação estrutural e missionária da paróquia um presbítero muito mais dedicado à espiritualidade e à evangelização do que a

\footnotetext{
${ }^{643}$ Cf. ALMEIDA, A. J. Modelos eclesiológicos e ministérios eclesiais. In: Revista Eclesiástica Brasileira. Petrópolis: Vozes, v. 48, fasc. 190, junho, 1988.

${ }^{644}$ BRAMBILLA, F. G. La parrocchia oggi e domani, op. cit., p. 70.

${ }^{645}$ Ibid., pp. 70-71. "Existe uma correspondência especifica entre concreta imaginem da igreja (paróquia) e figura histórica do ministério (do pároco)". BRAMBILLA, F. G. La parrocchia oggi e domani, op. cit., p. 73.
} 
questões administrativas. Voltamos a insistir que sinal de Deus num lugar é a comunidade e não o clero ${ }^{646}$, o que exige deste um cuidado maior com aquela que é sacramento de Deus. A nova identidade presbiteral, portanto, sem desconsiderar a dimensão do culto, as funções sacramentais, será acima de tudo a de um homem de comunhão pastoral. Trata-se de recuperar a figura comunional do ministério ordenado, suscitador de ministérios e carismas, animador da rede de comunidades. Nesta mudança 'geográfica' e existencial do ser e do fazer sacerdotal, a imagem utilizada por Brambilla é emblemática. Na família, com a chegada de um filho, todos precisam rever a própria função e lugar. Querer o nascimento de um novo filho eclesial, o laicato adulto e sujeito na evangelização, urge reorganizar a identidade, o lugar e a função do ministro ordenado ${ }^{647}$. Esse será sempre mais o homem da comunhão, chamado a ser menos protagonista direto, para ser uma presença capaz de animar uma comunidade, e no interior dessa, despertar fiéis protagonistas e responsáveis na missão ${ }^{648}$. É sua função fazer passar os carismas da colaboração à corresponsabilidade, ou em outras palavras, da figura que dá uma mão a uma presença que caminha dentro de um comum projeto pastoral ${ }^{649}$.

A teologia dos ministérios de Bruno Forte resume bem a questão, quando entende o ministério ordenado como "ministério da síntese, ele não se deve tornar síntese dos ministérios (concepção 'clericalizante'), mas serviço de discernimento e coordenação dos carismas e dos ministérios, com vistas à comunhão e ao crescimento $^{650}$. O sacerdócio deixa de ser o único e mais importante ministério na paróquia para tornar-se um 'promotor de ministérios variados e harmonicamente ligados entre si.

Neste particular, cabe uma reflexão sobre a relação dos ministros ordenados com o catecumenato. Sendo o interesse maior de nossa pesquisa a paróquia voltada para o diálogo com a iniciação à vida cristã, reside aqui uma das questões centrais. O envolvimento do presbítero, bispo, diácono com a caminhada catecumenal não se resume a administrar os sacramentos ou ritos catecumenais, mas acompanhar muito de perto aqueles que se preparam à vida cristã. Por não ser

\footnotetext{
${ }^{646}$ BORRAS, A. Aspectos teológicos e canônicos da remodelação paroquial, op. cit. In: BORRAS, A.; ROUTHIER, G. A Nova paróquia, op. cit., p. 144.

${ }^{647}$ BRAMBILLA, F. G. La parrocchia oggi e domani, op. cit., p. 245.

${ }^{648}$ Ibid., p. 245.

${ }^{649}$ Ibid., pp. 331-332.

${ }^{650}$ FORTE, B. 1987 , op. cit., p. 34.
} 
tão somente o homem do culto, o clero tem uma função de suma importância no acompanhamento, animação da comunidade eclesial iniciada da fé e dos que estão em iniciação cristã. Portanto, com a mudança de lugar do sacerdote, toda a comunidade será beneficiada, e de modo especial, a pedagogia da iniciação cristã catecumenal.

Torna-se oportuno e necessário ainda uma palavra a respeito da participação, corresponsabilidade dos batizados também nos canais de decisão da paróquia, e aqui nos referimos à sinodalidade, muito embora o termo não faça parte do vocábulo paroquial. Afirmar as mudanças de enfoque na ministerialidade paroquial, nova relação ministérios e comunidade, afirmar que corresponsabilidade é mais evangélico do que ajuda, precisa encontrar visíveis traduções institucionais. Os que dispomos são os conselhos paróquias, diocesanos, comunitários. O mais conhecido que a paróquia dispõe é o $\mathrm{CPP}$, conselho pastoral paroquial, que embora recomendado pela renovação conciliar, é, de acordo com o direito canônico, facultativo, e o parecer, consultivo ${ }^{651}$.

Como avançar na maturidade eclesial diante da não obrigatoriedade de canais de decisão, de organização e de planejamento pastoral, salvo se o bispo determinar? Embora o bom senso e a prática pastoral tem nos mostrado a existência de CPP em muitas paróquias, importa perceber não tratar-se de algo

${ }^{651}$ É no pós-concílio que o Conselho paroquial pastoral, CPP, vai ser implantado na vida das paróquias. São poucos os textos que aludem ao tema. Alguns textos oficiais da Igreja no posconcílio dizem respeito ao conselho diocesano (cf. AG 30, 2; Christus Dominus 27, 5); PO 7; por analogia surgiu assim também o CPP. É no documento da Sagrada Congregação dos Bispos Ecclesiae Imago pela primeira vez se fala explicitamente do CPP. "Para cultivar nos leigos o senso comunitário e acrescentar neles o empenho apostólico, podem dar uma notável contribuição os conselhos pastorais, seja diocesano, seja paroquiais". O número 179 pode ser considerado o texto mais significativo do documento “ (...) o bispo considerará como tipo ideal, aquela paróquia (...) na qual os leigos, com responsabilidade própria, tenham parte no CPP e dirijam as obras de apostolado que pertencem a eles". Ao fim, o documento diz que o bispo pode estabelecer que o CPP exista em toda paróquia da diocese. "Com a finalidade de tornar mais eficiente a atividade do Conselho (Diocesano), o bispo pode estabelecer que, para o bem dos fiéis, em toda paróquia, venha instituído, junto com os centros de apostolado, também o Conselho Pastoral Paroquial, e todos esses conselhos sejam coordenados pelo Conselho Diocesano" (n., 204). O que diz o CDC, afinal? O número 536 aborda o CPP com os seguintes termos: "A juízo do Bispo diocesano, ouvido o Conselho Presbiteral, se for oportuno, seja constituído em cada paróquia o Conselho Pastoral, presidido pelo pároco, no qual os fiéis ajudem a promover a ação pastoral, juntamente com os que participam do cuidado pastoral em virtude do próprio ofício 1). 2 O Conselho Pastoral tem somente voto consultivo e se rege pelas normas estatuídas pelo Bispo diocesano". O Código não diz ser obrigatório o $\mathrm{CPP}$, e no número seguinte diz ser obrigatório um Conselho para questões econômicas (CDC, 537). 
constitutivo da identidade da paróquia, como entende o Código. Renovação paroquial pede irrenunciavelmente maior colegialidade no gerir a paróquia. Torna-se insustentável as decisões da paróquia depender de uma só pessoa, que pretensiosamente possui todas as habilidades ou informações necessárias para tomar as decisões ${ }^{652}$. Não se pode subestimar a fato de outras pessoas verem com mais clareza certos desafios e 'soluções' por estarem mais diretamente envolvidas com as questões.

O principio da participação e decisão não anula a hierarquia eclesial. O que não é mais possível é insistir na concepção linear de hierarquia, entendida como uma ordem linear de entidades provenientes do Divino ${ }^{653}$. Portanto não se trata de rejeitar simplesmente a hierarquia ou a autoridade na paróquia, mas de entendê-la e realizá-la de outra forma. Nesta perspectiva, neste contexto de repensar a figura ministerial sacerdotal, impõe-se outra tarefa: refletir o sentido da autoridade do presbítero, do pároco, que longe de ser domínio é diaconia. "Sim, $o$ principio da hierarquia e o principio da participação não precisam estar em oposição, mas podem completar-se mutuamente numa eclesiologia baseada num modelo não linear" ${ }^{\prime 654}$.

A intuição de Almeida é pertinente ao processo de alargamento do CPP. Diz ele que poderia o Conselho ser enriquecido por outras pessoas, representantes dos professores, comerciantes, profissionais da saúde, comunicação, entidades sociais, associações de bairro, etc ${ }^{655}$. Trata-se de contar com o efetivo conhecimento de quem está inserido nestas realidades. Trata-se de dialogar com a sociedade, inserir a Igreja nesses ambientes, e para isso nada melhor do que a voz, a experiência de quem vive neste meio, chamado a evangelizar a partir de sua índole secular.

\footnotetext{
${ }^{652}$ Foi-se o tempo em que "o líder era alguém do qual, em virtude de uma sabedoria superior, ou força superior, ou ambas, se esperava que conhecesse todas as respostas às dificuldades que a comunidade poderia enfrentar. Seus seguidores não tinham de enfrentar os problemas nem as respostas, bastava-lhes aceitar a sabedoria do líder e (ou) sua força e executar suas instruções". GREELEY, A. Sociologia e estrutura da Igreja. Concilium, 8, 1970-8, p. 963.

${ }^{653} \mathrm{O}$ pseudodionísio aplica a concepção linear à hierarquia celeste dos espíritos angélicos e também à hierarquia eclesiástica. Nesta visão, os leigos são totalmente dependentes dos sacerdotes, esses dos bispos, os bispos do papa, a papa de cristo, e Cristo de Deus. Cf. FUELLENBACH, J. Igreja, comunidade para o Reino. São Paulo: Paulinas, 2006, p. 187.

${ }^{654}$ Ibid., p. 188.

${ }^{655}$ Cf. ALMEIDA, J. Paróquia, comunidades e pastoral urbana, op. cit., p. 193.
} 
É bem, verdade, que a participação nos canais de decisão da vida paroquial é uma responsabilidade que lhe requer maturidade, urge um laicato adulto. Chegamos, assim, novamente no círculo dialético. De um lado, exige-se um laicato bem formado para participar mais ativamente dos canais de decisão da paróquia. Um bom catecumenato irá formar cristãos conscientes e maduros,contudo, importa perceber que dar-lhe voz é constitutivo do amadurecimento humano e cristão.

Enfim, a questão da sinodalidade na paróquia, as instâncias de decisão e corresponsabilidade situam-se para além da mera execução das atividades. Tratase de uma gestão horizontal, corresponsável e interdependente.

\section{4 .5}

\section{Novos ministérios e uma paróquia toda ministerial}

Os ministérios se situam na natureza missionária da Igreja. "A Igreja peregrina é por sua natureza missionária, pois ela se origina da missão do Filho e da missão do Espírito Santo, segundo o designo de Deus Pai" (Ad Gentes, 2 a). Seríamos injustos se afirmássemos a ausência total de ministérios na paróquia. Leigos e leigas exercem diversos serviços nos mais diversos campos de evangelização. As questões que se levantam são fundamentalmente duas: A primeira remete ao fato de termos avançado lentamente na linha de uma 'Igreja toda ministerial', Povo de Deus, comunidade adulta de carismas e ministérios. Muito embora uma nova relação entre clero-leigo esteja em andamento desde o último Concílio Ecumênico, não se pode negar que há uma participação laical ainda limitada na Igreja ${ }^{656}$.

Em 1973, os bispos franceses, em Assembleia nacional realizada em Lurdes, lançaram um 'slogan': A Igreja é toda ministerial. Nesta Assembleia, o Pe. Congar define o termo ministério como: "serviço bem determinado, isto é, com uma tarefa concreta; que comporta uma verdadeira responsabilidade; reconhecida pela Igreja local, em um ato litúrgico; enfim, que tenha uma certa duração"657. A expressão acima mencionada somente pode ser entendido a partir

${ }^{656}$ Cf. SORAVITO, L. Rinovare la parrocchia a partire dagli adulti: riflessioni e schede de lavoro per operatori pastorali. Milano: Paoline, 2004, p. 131.

${ }^{657}$ Cf. VV. AA., Tutti responsabili nella Chiesa? Il ministero presbiterale in uma Chiesa tutta ministeriale. Turim, 1975, pp. 55-56; citado por R. Goldie, Teologia conciliare del laicato Allá 
de uma "um projeto pastoral que valorize todas as energias humanas presentes na Igreja" ${ }^{658}$, pois como bem recorda Alphonse Borras, “o pároco já não é o único 'agente de proximidade' na paróquia. Julgá-lo ou sonhar com isso, é conservar ainda o pressuposto do monopólio ministerial do pároco" ${ }^{659}$, muito embora "a maior parte dos fiéis não pensa realmente que é a comunidade que tem de significar a proximidade de Deus neste lugar" ${ }^{\circ 60}$.

A segunda questão a ser posta para o surgimento de novos ministérios é de ordem da necessidade, isto é, diante das transformações em curso e dos conseguintes desafios à transmissão da fé, a paróquia não pode contentar-se com um número reduzido de ministérios e carismas. A nova realidade, marcada pela diversidade cultural, os novos areópagos, reclama nova presença da Igreja naqueles lugares, consequentemente, diferentes serviços, carismas e ministérios à serviço da missão.

Na Encíclica 'Deus Caristas est', $n$. 25, encontramos a seguinte afirmação: “A natureza íntima da Igreja exprime-se num tríplice dever: anúncio da Palavra de Deus (kerygma-martyria), celebração dos Sacramentos (leiturgia), serviço da caridade (diakonia). São deveres que se relacionam mutuamente, não podendo um ser separado dos outros". As três dimensões, por sua vez, se expandem numa variedade de atuação, o que significa que para levar a sério a incumbência que lhes competem, a paróquia é convocada a transformar-se simultaneamente em rede de comunidades e rede de ministérios, o que subentende a criação de novos ministérios, configurados de forma diversificada em cada lugar, segundo as necessidades. O documento de Aparecida toca no cerne da questão em ao menos

prova dei fatti. Pul, Roma, 1981. É importante uma palavra sobre a distinção de carismas e ministérios, sem separa-los, pois alguns textos no Novo Testamento mostram uma íntima relação entre carisma e serviços e ministério (1 Cor 12, 4-11.28-30; Rm 12, 4-8; Ef 4, 10-13). Há, contudo diferenças entre as duas realidades: "Há forte tendência, hoje, na teologia e na prática pastoral, de considerar ministério, fundamentalmente, o carisma que assume a forma de serviço à comunidade e à sua missão no mundo e na Igreja e que, por esta, é como tal acolhido e reconhecido". CONFERÊNCIA NATIONAL DOS BISPOS DO BRASIL. Missão e ministérios dos cristãos leigos e leigas, op. cit., n. 83). Nesta perspectiva, nem todo carisma é ministério. "Mas só pode ser considerado ministério o carisma que, na comunidade e em vista da missão na Igreja e no mundo, assume a forma de serviço bem determinado, envolvendo um conjunto mais ou menos amplo de funções, que responda a exigências permanentes da comunidade e da missão, seja assumido com estabilidade, comporte verdadeira responsabilidade e seja acolhido e reconhecido pela comunidade eclesial" Idem, n, 86.

${ }^{658}$ Cf. SORAVITO, L. Rinovare la parrocchia a partire dagli adulti, op. cit., p. 31.

${ }^{659}$ BORRAS, A. Aspectos teológicos e canônicos da remodelação paroquial. In: BORRAS, A.; ROUTHIER, G. A nova paróquia, op. cit., p. 132.

${ }^{660}$ Ibid., p. 145. 
duas afirmações: "uma paróquia renovada multiplica as pessoas que realizam serviços e acrescenta os ministérios"; "só através da multiplicação deles podemos chegar a responder às exigências missionárias do momento atual” (DAp, 174).

Neste particular, cabem as perguntas: que outros ministérios poderiam servir à tarefa da transmissão da fé, além do específico ministério do introdutor, padrinhos e catequistas? Quais outros serviços que o ministério específico do primeiro anúncio (introdutor) pode despertar? Há igualmente espaço para o questionamento de muitas frentes de evangelização, como por exemplo, no vasto campo da Palavra de Deus. O ministério da Palavra não está por demais concentrado na celebração da Palavra, quando não há ministro ordenado para celebração da eucaristia? O Documento da CNBB sobre as paróquias diz que um "destaque especial deve ser dado ao Ministério da Palavra, por meio do qual homens e mulheres tornam-se autênticos animadores de comunidades"661. Seria possível uma atuação deste e de outros ministérios num âmbito mais alargado do que os limites do templo? As respostas não são tão evidentes como se parece, por isso mesmo urge criatividade para pensar em novas possibilidades de primeiro anúncio, novas presenças eclesiais, novos ministérios que percorram com as pessoas um trecho do caminho, que compartilhem de seus dramas e suas angússtiasm, que os ajude no retorno à comunidade eclesial.

Um prévio esclarecimento diz respeito à distinção entre ministérios 'ad intra' e ministérios 'ad extra', que em hipótese alguma se baseia numa visão eclesiológica ou teológica que separa inadequadamente Igreja e mundo, ou vida e missão da Igreja ${ }^{662}$. Queremos chamar a atenção que "a paróquia não pode ser monoministerial, e os ministérios não podem ser só litúrgicos. É preciso criar um dinamismo de fundo e um espírito que despertem e valorizem todos os dons e carismas presentes na comunidade" ${ }^{663}$. A afirmação de que o campo específico do

\footnotetext{
${ }^{661}$ CONFERÊNCIA NATIONAL DOS BISPOS DO BRASIL. Comunidade de comunidades, op. cit., n. 310 .

${ }^{662}$ Não é preciso 'sair' da Igreja para 'ir' ao mundo, como não é preciso 'sair' do mundo para 'entrar' e viver' na Igreja, além do que "a compreensão da Igreja como 'sacramento de salvação' exige a superação entre um 'ad intra' (em que a Igreja existiria e funcionaria em si e para si) e um 'ad extra' (em que a Igreja ou parte dela agiria a serviço do mundo). CONFERÊNCIA NATICONAL DOS BISPOS DO BRASIL. Missão e ministérios dos cristãos leigos e leigas, op. cit., n. 90.

${ }^{663}$ Cf. ALMEIDA, A. Paróquia, comunidades e pastoral urbana, op. cit., p. 187. Cf. também ALMEIDA, A. J. Os ministérios não-ordenados na Igreja latino-americana, op. cit.
} 
agir do leigo é o secular ${ }^{664}$ pode contrastar com a escassez de ministérios e serviços voltados às realidades temporais, extra-templo, capaz de acompanhar os dramas humanos em que vivem as pessoas. Aparecida recorda "que o campo específico da atividade evangelizadora leiga é o complexo mundo do trabalho, da cultura, das ciências e das artes, da política, dos meios de comunicação e da economia, assim como as esferas da família, da educação, da vida profissional, sobretudo nos contextos onde a Igreja se faz presentes somente por eles" (DAp, 174). Consequentemente, "neste campo, se requer imaginação para encontrar respostas aos muitos e sempre mutáveis desafios que a realidade coloca, exigindo novos serviços e ministérios" (DAp, 174).

Digna de nota é a valorização que o Documento da Conferência Episcopal do Brasil sobre a missão e ministérios dos cristãos dá ao ministério social:

Por que, por exemplo, as pastorais sociais podem ser consideradas verdadeiros ministérios? Porque as pastorais sociais, por exemplo, não são atuações de pessoas ou grupos de pessoas em nome próprio, mas atuações da Igreja em determinado campo da vida humana. Os seus agentes são verdadeiros ministros. Por isso se deverá falar de 'ministério e não simplesmente de serviço cristão para todas as funções importantes exercidas em nome da Igreja, que respondam a uma necessidade permanente ${ }^{665}$.

Nesta perspectiva, o reconhecimento do ministério social abre perspectivas para uma maior atuação extra-paroquial também ministerialmente, independentemente do nome que as funções venham a receber. De fundamental importância é o reconhecimento e mandato oficial da Igreja. "Determinante é o fato; o nome é secundário. Sob o aspecto formal, tanto o catequistas quando o

\footnotetext{
${ }^{664}$ Em diversos documentos eclesiais fala-se da índole secular própria da evangelização dos leigos. Recentemente, na Exortaçao Ecclesia in America, o então papa João Paulo II fala do 'primeiro e mais condizente com o seu estado laical, o das realidades temporais, que (os leigos) são chamados a ordenar conforme a vontade de Deus" (EA, 44). Evangelli Nuntiandi descreve esse campo como "o mundo vasto e complicado da política, da realidade social e da economia, como também o da cultura, das ciências e das artes, da vida internacional, dos 'mas mídia' e, ainda, outras realidades abertas para a evangelização, como sejam, o amor, a família, a educação das crianças, e dos adolescentes, o trabalho profissional e o sofrimento" (EN, 70 citado também em ChL, 23). A Constituição Lumen Gentium, com propriedade afirma que "compete aos leigos a principal responsabilidade' de impregnar o mundo do espírito de Cristo, a tornar operante e presente a Igreja naqueles lugares (LG, $36 \mathrm{~b} ; 33 \mathrm{~b}$ ).

${ }^{665}$ CONFERÊNCIA NATIONAL DOS BISPOS DO BRASIL. Missão e ministérios dos cristãos leigos e leigas, n. 91, que citou. LEGRAND, M. Ministerios em la Iglesia local, em: AA. VV., Iniciación a la práctica de la teologia. Madrid, 1985, vol. III, p. 218.
} 
líder da Pastoral da Criança quanto o animador do grupo de vivência quanto ‘ministro extraordinário da comunhão eucarística' são ministros ou ministras"

\section{5}

\section{As etapas da iluminação/purificação e mistagogia e a conversão mistagógica paroquial}

Resta ainda, em nossa pesquisa, refletir alguns elementos da paróquia à luz dos dois últimos tempos da caminhada catecumenal, a saber, iluminação/purificação e mistagogia. Sinteticamente, nosso trabalho até o momento esteve assim estruturado: à luz do pré-catecumenato refletimos as dimensões missionária e kerigmática da paróquia; à luz do catecumenato abordamos alguns elementos estruturais e organizacionais da instituição paroquial, tais como a formação, os ministérios, rede de comunidades, pequenas comunidades, dentre outros aspectos; e por fim, à luz da iluminação/purificação e mistagogia abordaremos as dimensões orante, contemplativa, experiencial, mistagógica na instituição e nas pastorais paroquiais.

Algumas observações são necessárias antes de adentrar na reflexão. O tempo da mistagogia, último momento do processo catecumenal, não significa que os outros tempos não sejam igualmente mistagógicos. A riqueza catecumenal consiste em garantir uma forte densidade orante, mistagógica e experiencial da fé durante todo o processo formativo. Do início ao fim, o antes, o durante e o depois da recepção dos sacramentos visam imprimir o caráter mistagógico da iniciação à vida cristã. Os últimos momentos do itinerário catecumenal, iluminação/purificação e mistagogia, rementem à dimensão mais orante e experiencial da fé, sem dicotomia ou exclusivismo. Trata-se de acento, de ênfase cronológica e não de exclusivismo. Assim, a evangelização está enfatizada no início do processo da iniciação cristã; a catequese, no tempo do catecumenato; a conversão e contemplação, na iluminação/purificação; e a mistagogia, no último período da formação cristã.

Outra observação pertinente é a junção que aqui fizemos dos dois últimos tempos do itinerário catecumenal, conforme o presente subtítulo, no intuito de enfatizar o sentido que daremos a essas duas etapas na instituição paroquial.

\footnotetext{
${ }^{666}$ ALMEIDA. J. A. Paróquias, comunidades e pastoral urbana, op. cit., p. 16.
} 
Expliquemos melhor! A iluminação/purificação, tempo para maior interiorização e conversão no processo catecumenal, recorda à paróquia o imperativo da conversão pastoral e estrutural, assunto constantemente visitado por nós no decorrer da pesquisa, sobretudo quando abordávamos às mudanças estruturais necessárias à missionariedade, no diálogo com a etapa pré-catecumenal. Enfatizaremos agora a conversão pastoral. Conversão pastoral em que ou para que? À expressão conversão pastoral pode se atribuir inúmeros significados, todos legítimos e necessários. O caminho percorrido até o momento, na busca de um novo perfil de paróquia, de certa forma contemplou várias dimensões relativas à expressão. Conversão para uma paróquia toda ministerial, conversão à rede de comunidades, conversão para o impulso à missionariedade, à colegialidade, conversão para o serviço e à caridade, aos pobres, a uma nova mentalidade pastoral, que mais do que sacramentalizar ou ensinar proporcione processos pastorais que levem à descoberta e ao aprofundamento da fé, etc. Como síntese de todas as conversões a que a paróquia é convocada a entrar, trazemos agora o termo mistagogia, em debate com o último tempo do itinerário catecumenal. Dito diferente, enfatizaremos aqui, como que síntese de todos os aspectos já mencionados, a conversão pastoral à mistagogia. Percebe-se, portanto, que com a expressão conversão pastoral à mistagogia envolvemos as duas últimas etapas catecumenais: conversão (iluminação/purificação) e mistagogia.

\subsection{1}

\section{Mistagogia e experiência}

Para melhor entender o alcance da afirmação da conversão pastoral paroquial à mistagogia torna-se oportuno recorrer à aproximação entre mistagogia e experiência. $\mathrm{Na}$ mistagogia catecumenal o acento repousa na dimensão experiencial do mistério de Jesus Cristo e da vivência em comunidade. O Ritual da Iniciação Cristã dos adultos traduz isto afirmando a dúplice experiência para este tempo: experiência dos sacramentos e experiência da comunidade eclesial $^{667}$.

\footnotetext{
667 Vale lembrar que o termo experiência é utilizado não poucas vezes pelo Ritual do catecumenato. 'Nos quarenta parágrafos da parte principal do RICA, a expressão 'experiência' é empregada em nove ocasiões, seis das quais em direta relação com a mistagogia, uma ao falar do
} 
A característica maior da mistagogia está em oferecer ao catecúmeno uma maior oportunidade para degustar, celebrar e atualizar a graça sacramental e a caminhada da fé realizada no processo da iniciação cristã. Os mistérios sacramentais recebidos são agora mais conscientemente vivenciados: É tempo privilegiado para "o conhecimento mais completo e frutuoso, novas explanações e, sobretudo, a experiência dos sacramentos recebidos" (RICA, 38). Em outros termos, trata-se de um tempo para aprofundar a experiência do mistério celebrado, para saborear aquilo no qual se foi iniciado sacramentalmente. Consequência disto é que os sacramentos só têm valor salvífico por serem canais sacramentais de experimento do mistério. Continua o Ritual: "Mistagogia (...) um tempo para a comunidade e os neófitos crescerem juntos aprofundando sua apreensão do mistério pascal ...” (RICA, 37). Destacamos a expressão "comunidade e os neófitos crescerem juntos", o que revela que sem mistagogia, sem experiência não se cresce na vida de fé, não se apreende o mistério pascal.

Posto isto, torna urgente considerar que a experiência ou mistagogia da fé é um direito não somente dos catecúmenos, mas de todas as pessoas, os frequentadores assíduos, os casuais, os 'clientes' ou os afastados da paróquia. Contudo, bem sabemos que a dimensão experiencial da fé é, sem dúvida, a grande lacuna na paróquia, seja pelo excesso de atividades, refém de uma infinidade de tarefas, seja pela forte carga burocrática e institucional, sem proporcionar, na maioria das vezes, a experiência mistagógica ${ }^{668}$. A afirmação já feita de que grande parte dos já batizados não é iniciada na fé pode ser retomada agora em perspectiva mistagógica, ou seja, considerável número de batizados carece da experiência de Deus, de uma religiosidade mais vivencial, cuja consequência é: ou se cumpre preceito, ou busca-se serviço religioso, ou se afasta definitivamente da paróquia. Daí se entende com mais facilidade o porquê de muitos viverem, hoje, uma espiritualidade fora da instituição paroquial ou mesmo fora da religião.

pré-catecumenato, e duas com referência ao catecumenato". REGAN, D. Experiência cristã das comunidades de Base: mistagogia. São Paulo: Paulinas, 1995, p. 52.

668 "Por isso, não é de se estranhar que no momento em que por todas as partes surgem movimentos carismáticos questionando uma racionalidade instrumental em nome da subjetividade, também a igreja Católica, que carrega sua carga no institucional, seja atravessada em seu interior por onda carismática pentecostal. Há, portanto, compensando o enorme déficit carismático dos séculos passados, um superávit carismático sob forma messiânica, espiritualista, neopentecostal". LIBANIO, J. B. A lógica da cidade, op. cit., p. 77. 
É importante que se reafirme que o encontro, a experiência pessoal e comunitária com o Deus de Jesus Cristo, portanto, a mistagogia, é o grande desafio pastoral da atualidade, marcada por uma cultura carente de experiências mais profundas. Acertadamente, Rahner já profetizava: “O cristão devotado do futuro ou será um 'místico', alguém que experimentou algo, ou deixará de ser qualquer coisa que seja"669. Assim se expressa o vigente documento de estudo da CNBB sobre as paróquias:

A nova evangelização exige um renovado empenho para proporcionar um encontro pessoal e comunitário com Jesus Cristo. Para isso, será preciso criar espaços, momentos e condições para que esse encontro se realize. Essa experiência é, ao mesmo tempo, íntima e pessoal, pública e comunitária ${ }^{670}$.

A relevância da experiência remete primordialmente à exigência da própria fé, sobretudo hoje quando esta não está mais respaldada na cultura, como outrora, mas no testemunho e no próprio sujeito sedente da experiência de Deus. Nas palavras de França Miranda,

Respaldar sua fé na experiência pessoal é uma exigência tal antiga como o cristianismo. De fato é o próprio Deus quem nos capacita a crer em Jesus Cristo, é o próprio Espírito Santo quem garante a solidez de nossa opção. Contudo, pôde esta verdade não estar tão presente na consciência de nossos antepassados, devido à força do suporte social da fé, que eram a sociedade e a Igreja. Hoje contudo ganha ela uma importância enorne ${ }^{671}$.

Importância essa similar aos primórdios da vida cristã. Afirma Comblin que dois fatos de igual importância marcaram o início do cristianismo: Jesus, sua vida, morte e ressurreição, e a experiência do Espírito Santo nas comunidades primitivas $^{672}$.

Mistagogia no catecumenato, experiência na paróquia, nas pastorais e movimentos, independente do termo utilizado, trata-se fundamentalmente de condição para o futuro do cristianismo. Vale a pena enfatizar que todo o esforço de busca de renovação paroquial em andamento, à luz da pedagogia catecumenal,

\footnotetext{
${ }^{669}$ RAHNER, K., citado por REGAN, D. Experiência cristã das comunidades de base, op. cit.; p. 35 .

${ }^{670}$ CONFERENNCIA NATIONAL DOS BISPOS DO BRASIL. Comunidade de comunidades: uma nova paróquia, op. cit., n. 172.

${ }^{671}$ MIRANDA, M. F. Ser cristão numa sociedade pluralista, op. cit., p. 343.

${ }^{672}$ Cf. COMBLIN, J. O Espírito Santo e a libertação. Vozes: Petrópolis, 1987, pp. 17 e 113.
} 
visa a renovação paroquial capaz de favorecer profunda experiência de Deus. Nova linguagem, símbolos, homilias, estrutura, pastorais, serviços e movimentos, enfim, qualquer realidade existente na paróquia não são fins em si mesmas, mas sua pertinência reside na capacidade de gerar experiência mistagógica. A partir de nossa proposta dialética entre catecumenato e paróquia, com a mesma intensidade que se afirma o novo paradigma de iniciação à vida cristã, voltado à experiência, a estrutura paroquial quer se reconfigurar tendo como eixo norteador esta mesma experiência, tornando-se casa da mistagogia, ou ainda em tom mais enfático, em estado permanente de mistagogia. Trata-se do esforço ininterrupto para em tudo o que a paróquia fizer favorecer aos fiéis a mistagogia, ou o esforço de reorganização paroquial será paliativo, sem tocar as raízes do problema. Nesta perspectiva, vemos que o circulo dialético vai se realizando. Do mesmo modo que mistagogia não é apenas o último tempo do processo da iniciação cristã, mas sua espinha dorsal, assim também todas as possíveis mudanças estruturais e pastorais na paróquia visam uma maior experiência mistagógica de fé. Mistagogia não é algo que a paróquia oferece aos fiéis, mas é fundamentalmente aquilo no qual ela mesma a chamada a se converter, para, então, poder ser experimentada como lócus da experiência de Deus. Só aí, então, ela será capaz de “oferecer a todos os nossos fiéis um encontro pessoal com Jesus Cristo, uma experiência religiosa profunda e intensa" (DAp, 226).

O caminho é de mão dupla. Se as mudanças da paróquia visam a conversão estrutural e pastoral para uma maior experiência de Deus e da comunidade cristã, ao mesmo tempo que tais experiências se efetuam, mais facilmente novas reestruturações na paróquia se tornam realidade. Sem mistagogia não se chega à mudança estrutural, pois esta é fundamentalmente consequência daquela $^{673}$. O mesmo vale para a missionariedade, com maestria recordado pelo papa Francisco. “A mudança de estruturas' (de caducas a novas) não é fruto de um estudo de organização estática, mas é consequência da missão. O que derruba as

673 “A conversão pastoral depende de uma conversão pessoal a Cristo. Não haverá mudanças no agir se não houver um profundo encontro com Jesus capaz de renovar a pessoa". CONFERÊNCIA NATIONAL DOS BISPOS DO BRASIL. Comunidade de comunidades: uma nova paróquia (texto ainda não publicado), op. cit.,n. 173. 
estruturas caducas, o que leva a mudar os corações dos cristãos é justamente a missionariedade. Daqui a importância da missão paradigmática"674.

E por fim, não podemos esquecer que a urgência mistagógica direciona-se à vida e ao ministério dos agentes de evangelização, de modo especial aos presbíteros, chamados a serem homens de profunda experiência de Deus. "Essa vivência de discípulo fará o pároco ir ao encontro dos afastados de sua comunidade; caso contrário, contentar-se-á com os aspectos da administração e promoverá uma pastoral de conservação"675. Continua o documento: "Em primeiro lugar, o pároco precisa ser um homem de Deus que fez e faz uma profunda experiência de encontro com Jesus Cristo. Sem esta mística, toda renovação ficará comprometida" ${ }^{676}$.

Nossa reflexão, a seguir, se concentrará em quatro 'lugares' teológicopastorais prenhes de potencialidade da experiência mistagógica, cientes da existência de muitos outros. Poderíamos abordar os sacramentos como lócus mistagógico, de modo especial o sacramento da reconciliação, como experiência da misericórdia e do abraço de Deus. Optamos pela Palavra, pela liturgia, pela religiosidade popular e pelas pastorais, sendo esta última abordada a partir de uma visão geral, sem pormenorizar nenhuma delas. Interessa-nos reafirmar o espírito mistagógico que deve mover as mais diversas atividades na paróquia ${ }^{677}$. São, portanto, quatro lócus da mistagogia que, no entanto, por vezes não passam do estágio da manutenção pastoral. Torná-las novamente casa da mistagogia é tarefa urgente.

\section{5 .2}

\section{A mistagogia na Palavra de Deus}

Nada mais propício à conversão e à experiência de Deus do que o contato com a Palavra, que gera encontro, intimidade, possibilitando ao sujeito ler a própria história na História da salvação, da qual fazemos parte. A Palavra de Deus é sempre lugar teológico de conversão, de alimento da fé, de iluminação e inspiração de vida, de mistagogia. Reside nela, portanto, uma densidade

\footnotetext{
${ }^{674}$ PAPA FRANCISCO. Discurso aos dirigentes do CELAN, op. cit.

675 CONFERÊNCIA NATIONAL DOS BISPOS DO BRASIL. Comunidade de comunidades:

uma nova paróquia (texto ainda não publicado), op. cit., $n .178$.

676 Ibid.

${ }^{677}$ Entendemos por pastorais o conjunto de atividades pelas quais a Igreja realiza sua missão.
} 
mistagógica, ou em outros termos, a Palavra de Deus é um caminho privilegiado para experimentar o Mistério.

Sobre o lugar da Palavra de Deus no processo catecumenal já refletimos direta e indiretamente no decorrer do presente trabalho. Seja nas celebrações, seja nos encontros, a Bíblia é o livro por excelência do catecumenato, e no tempo da iluminação ela recebe um destaque peculiar, necessário para que o eleito faça bem sua preparação espiritual, seu retiro, para a celebração dos sacramentos. Cabe, neste momento, uma reflexão sobre o lugar que a Palavra ocupa na 'agenda' da paróquia. Como ponto de partida, afirmamos que conversão pastoral à mistagogia e a centralidade da Palavra caminham necessariamente juntas, caso contrário, a primeira não seria genuinamente conversão, e a segunda estaria deslocada do centro.

A segunda observação diz respeito à equivalência ou aproximação entre centralidade da Palavra no catecumenato e 'animação bíblica de todas as pastorais', insistente pedido da Igreja nos últimos anos. Se no catecumenato a Palavra de Deus é o principal 'material' de que dispõe os catecúmenos e os ministérios responsáveis pela iniciação, na evangelização paroquial, em seu conjunto de ações, fala-se de 'animação bíblica de todas as pastorais ${ }^{678}$. Portanto, ambos, catecumenato e as demais atividades da Igreja, estão convocadas a uma conversão na Palavra e para a Palavra, contudo é bem verdade que na metodologia catecumenal se pode melhor visualizar tal conversão, ou seja, no catecumenato torna-se mais evidente a 'animação bíblica' por meio de um projeto claramente delineado no qual a Palavra perpassa o ritmo das atividades, dos tempos e das etapas catecumenais.

Torna-se evidente que a paróquia deve caminhar para a superação de uma pastoral bíblica para a 'animação bíblica de todas as pastorais', no intuito de "redescobrir o contato pessoal e comunitário com a Palavra de Deus como lugar privilegiado de encontro com Jesus Cristo" (DAp, 247). A Palavra de Deus não pode ser concebida como material específico de uma única pastoral, ao contrário,

678 "Passar de uma Pastoral Bíblica para uma Animação Bíblica da Pastoral”. Os participantes do Sínodo dos Bispos, realizado em outubro de 2008, sobre a "Palavra de Deus na vida e missão da Igreja" apontaram definitivamente para esta nova linguagem e nova compreensão, quando afirmam na Proposicão 30: “A 'pastoral bíblica' não deve ser justaposta com outras formas da pastoral, mas deve ser entendida como 'animação bíblica de toda a pastoral"”. 
é a alma de todo agir eclesial, "a alma da ação evangelizadora da Igreja" (DP, 372; DAp, 248).

A prioridade da Palavra, além de outros benefícios à comunidade, ajuda a "evitar o risco de uma abordagem individualista, tendo presente que a Palavra de Deus nos é dada precisamente para construir comunhão, para nos unir na Verdade no nosso caminho para Deus" (VD, 86).

Muitas iniciativas já existem no tocante à animação bíblica. As pastorais mais diretamente envolvidas com a Bíblia têm uma função especial neste empreendimento de colocar a paróquia em contato permanente com a Palavra. Destacam-se e merecem sempre mais incentivo os círculos bíblicos ${ }^{679}$, a leitura orante da Palavra de Deus, que favorece a leitura orante da vida. Urge sempre mais implantar a prática de leitura orante da Palavra, com o método da Lectio Divina, em todas as instâncias pastorais, que sem dúvida é um meio eficaz de realizar a contínua 'animação bíblica da pastoral'.

Referência da centralidade bíblica são as Cebs, nas quais se proporciona um olhar para a realidade a partir da Palavra de Deus que ilumina a vida e impulsiona a caminhada. Inúmeras comunidades e lideranças nasceram da leitura comunitária da Bíblia, o que mais uma vez evidencia que a renovação paroquial passa necessariamente por um novo relacionamento com a Palavra de Deus. À medida que a Bíblia oxigenar as pastorais, novos horizontes vão sendo vislumbrados, antigas práticas vão sendo corrigidas.

\section{5 .3}

\section{Pastorais mistagógicas}

O Papa Francisco, com extrema pertinência, tem denunciado atitudes pastorais obsecadas pelo ritualismo ou normalismo sem alma. Não se trata, obviamente de descartar o doutrinal, mas de perceber que o conjunto de preceitos está a serviço da experiência da fé e não o contrário. Doutrinal, rito, palavras querem expressar e recordar um encontro primeiro, uma experiência fundante, caso contrário, tornar-se-iam fins em si mesmos. Exemplo disto pode ser buscado

${ }^{679}$ Dentre as maiores contribuições para aproximar a Bíblia do povo, destaca-se a de Frei Carlos Mesters. Cf. CAVAlCANTI, T. O Método de Leitura Popular da Bíblia na América Latina. A contribuição de Carlos Mesters. Tese de Doutorado em Teologia pela PUC do Rio de Janeiro, 1991. 
no rito dos parabéns no momento do aniversário. Porque cantamos os parabéns a alguém especial, senão pelo fato dela existir? Parabenizo-te pela tua existência! $\mathrm{Na}$ medida em que os parabéns torna-se uma regra, um rito mecânico a ser repetido, não consegue mais exprimir a alegria pelo existir do outro.

Para o bispo de Roma, a Igreja não pode ser "obcecada" com a transmissão de "doutrinas desarticuladas que se tenta impor de forma insistente. A proposta do Evangelho tem que ser simples, profunda, radiante. É dessa proposta que as consequências morais então fluem". Recorda ele que "na América Latina e no Caribe, existem pastorais 'distantes', pastorais disciplinares que privilegiam os princípios, as condutas, os procedimentos organizacionais ... obviamente sem proximidade, sem ternura, nem carinho" ${ }^{680}$. Dito em outros termos, são pastorais, metodologias, encontros "sem comunicar experiências de fé" 681 . Lamentavelmente,

Há pastorais posicionadas com tal dose de distância que são incapazes de conseguir o encontro: encontro com Jesus Cristo, encontro com os irmãos. Este tipo de pastoral pode, no máximo, prometer uma dimensão de proselitismo, mas nunca chegam a conseguir inserção nem pertença eclesial ${ }^{682}$.

A mesma intuição encontramos no Ritual de Iniciação Cristã, quando afirma que a catequese deve levar o catecúmeno "não só ao conhecimento dos dogmas e preceitos, como a íntima percepção do mistério da salvação de que desejam participar” (RICA, 19). Podemos traduzir, portanto, intima percepção do mistério da salvação como experiência, mistagogia, sem as quais o mistério da salvação não lhe será pertinente, significativo, por conseguinte, não será salvífico.

Diante de tais tendências pastorais, afirmamos que somente a conversão à mistagogia ser capaz de superar atitudes estritamente disciplinares. Nesta perspectiva, conversão pastoral aponta para o fim dos cursinhos pastorais, sobretudo aqueles em preparação aos sacramentos. Chegou o tempo do seu esgotamento, carecendo urgentemente serem substituídos pela processualidade da

\footnotetext{
${ }^{680}$ PAPA FRANCISCO. Discurso aos dirigentes do CELAN, op. cit.

${ }^{681}$ CONFERÊNCIA NATIONAL DOS BISPOS DO BRASIL: Comunidade de comunidades: uma nova paróquia, (texto ainda não publicado), op. cit., n. 47. ${ }^{682}$ Ibid.
} 
fé, por uma pedagogia celebrativa e experiencial ${ }^{683}$, enfim, por "pastoral em chave missionária" (EG, 33).

Refletíamos, já, o devido lugar dos sacramentos no processo da iniciação cristã catecumenal, que não são fins em si mesmos, mas expressão sacramental do mergulho no mistério. O mesmo deve ser posto em prática, portanto, nos demais sacramentos, para não reforçar ainda mais a tendência ao clima de clientes religiosos. Definitivamente, o mero repasse de conteúdo não gera experiência. Bem sabemos que a linguagem estritamente racionalista não comunica o mistério, o que significa que cada vez mais as pastorais são desafiadas a por a ênfase mais na experiência do que nos conteúdos expositivos ou no doutrinal. Recorda Almeida que

"Se a pastoral tradicional esteve centrada na 'objetividade da fé' (expressa na confissão da reta doutrina, na eficácia ex opere operato dos sacramentos, na disciplina moral e canônica regidamente universal), a nova pastoral deverá (re) rentra-se no 'sujeito da fé', para que o homem urbano possa aceder à fé ou, então, vivê-la significativamente nos contextos diferenciados em que a complexa realidade urbana o coloca" ${ }^{\prime 684}$.

O que dizer do ativismo pastoral, ou das "atividades mal vividas, sem as motivações adequadas, sem uma espiritualidade que impregne a ação e a torne desejável” (EG, 82), preocupação esta legitima do papa Francisco. Nesta perspectiva, o tempo catecumenal de iluminação pode recordar à paróquia a necessidade e a conversão para ofertas maiores de momentos de espiritualidade, de encontro consigo mesmo, com os outros e com Deus. Os párocos, na maioria das vezes, são reféns do ofício administrativo, e os leigos mais comprometidos são reféns de intermináveis reuniões. Não é por acaso que Aparecida constata que muitos deixaram a Igreja por questões institucionais e burocráticas (DAp, 225). Além disso, aumentar a oferta de momentos de retiros e meditações são sempre necessários. Pistas de ação apontam ainda para o fortalecimento dos tempos fortes

\footnotetext{
${ }^{683}$ A título de exemplificação no tocante à experiência mistagógica na ação paroquial, tomemos a preparação ou realização dos sacramentos, ou mais particularmente a celebração do batismo, na qual não se estranha que um número significativo de pessoas não praticantes da comunidade se faça presente nesta ocasião. Para muitos, tal momento é único ou raro contato com a comunidade cristã, o que aumenta o desafio e ao mesmo tempo a possibilidade de ser-lhes oferecida uma experiência de Deus, através da celebração, que envolve desde o ambiente, a acolhida, os cantos etc. A mesma reflexão cabe aos cursos de preparação aos sacramentos, ocasião propícia a um encontro mistagógico, se a metodologia, a linguagem forem também mistagógicas.

${ }^{684}$ ALMEIDA, J. A. Paróquia, comunidades e pastoral urbana, op. cit., p. 200.
} 
do ano litúrgico, semana santa, as grandes festas litúrgicas, além de ambientes e momentos diversos para o cultivo da espiritualidade.

Cada vez torna-se mais recorrente por parte dos agentes de pastorais reclamações de sobrecarga de serviço. 'Estamos cansados e somos poucos' é frase comum nos bastidores das pastorais. O perigo do ativismo pastoral sempre existiu, desde os primórdios da vida cristã, e hoje se tem a impressão que nas paróquias trabalha-se demais, devido ao peso estrutural, em detrimento da oração, da meditação e da mística.

A conversão pastoral à mistagogia requer igualmente o cuidado com as metodologias pastorais, clareza dos objetivos, reuniões objetivas, mais vivenciais do que burocráticas. Requer, ainda, a revisão dos costumes, estilos, horários, linguagem ${ }^{685}$. E por fim, não poderíamos deixar passar desapercebida ou dar um destaque a necessária dimensão sócio transformadora, a centralidade dos pobres na ação pastoral. Assim como falávamos da mudança de perspectiva de pastoral bíblica para a animação bíblica de toda pastoral, não se trata, aqui, de mais uma pastoral, de contentar-se com a pastoral social. A conversão pastoral à mistagogia exige incorporar no fazer e no ser da paróquia a mística do cuidado, e o do cuidado preferencial aos relegados da sociedade. Portanto, o lugar que o pobre ocupa na agenda paróquia revela sua real conversão ou manutenção pastoral. Num mundo onde a maior parte da população carece dos bens necessários à vida, não deveria a paróquia ser uma estrutura eclesial mais simples e pobre?

\section{5 .4}

\section{Liturgias mistagógicas}

O tema da liturgia já foi refletido em outros momentos da pesquisa, sob o viés da interação catequese-liturgia. Voltaremos agora ao mesmo tema, contudo, sob outro ângulo, aquele que nos interessa no momento: a mistagogia. Apesar de termos utilizado a expressão no plural, liturgias, a liturgia eucarística recebe uma centralidade. Eucaristia é por excelência o lugar da experiência mistagógica, nem por isso queremos desconsiderar as demais expressões litúrgicas. "Ela é o encontro de Deus com a comunidade, da comunidade com Deus e dos membros

\footnotetext{
${ }^{685}$ Cf. CONFERÊNCIA NATIONAL DOS BISPOS DO BRASIL. Comunidade de comunidades,
} op. cit., n. 59. 
da comunidade entre si" ${ }^{686}$. À luz da riqueza da liturgia catecumenal, tão central para o processo de iniciação cristã, um passo a frente pede uma reflexão sobre o mistagogia, contudo, não somente na eucaristia, mas no conjunto da liturgia paroquial.

A liturgia continua sendo uma das principais atividades da paróquia. Considerável parte da agenda paroquial é dedicada ao culto, o que reforça a necessidade da pergunta se as liturgias paroquiais são mistagógicas, lugares do experimento e da vivência do mistério. Por natureza, é pela ação litúrgica que somos iniciados e mergulhados no mistério. Uma palavra da Escritura, um aperto de mão, um abraço, um gesto de oração, a água benta, um silencio profundo, uma aclamação vibrante, o Pão e Vinho partilhados, a unção com óleo, tudo isso pode ser um momento de descoberta, de experiência profunda do amor de Deus em nós. Tudo isso pode aumentar nossa opção por ele ${ }^{687}$.

Neste particular, cabe aos símbolos - cujo poder de evocar o mistério é inquestionável, um papel de suma relevância no tocante à experiência mistagógica. Entendemos por símbolos um campo maior do que o propriamente os objeto simbólicos. Afirmar a liturgia, e nela os símbolos como lócus da experiência do mistério, entram em cena diversos elementos: o canto, o ambiente, os gestos e ritos, o silêncio, a Palavra proclamada, a linguagem, a homilia em chave kerigmática e mistagógica, a assembleia reunida, e naturalmente os símbolos propriamente ditos, cuja força comunicativa supera em muito o racionalismo, que dificilmente toca ao coração onde habita o mistério. Vale lembrar que na cultura do ocidente se tem dado mais ênfase à linguagem verbal, o que significa estarmos em débito com a gramática dos símbolos. Daí a importância de constante sensibilidade para a busca de símbolos apropriados e inculturados.

São muitas, portanto, as riquezas, possibilidades de uma profunda experiência mistagógica na liturgia. Por outro lado, não poucas vezes, deparamonos com ritualismos, posturas, que não são capazes de evocar o mistério, como também não o são as liturgias não participativas ou massissas. Já não consegue a

${ }^{686}$ CONFERÊNCIA NATIONAL DOS BIPOS DO BRASIL. Comunidade de comunidades: uma nova paróquia (texto ainda não publicado) op. cit., n. 183.

${ }^{687}$ Cf. BUUST, I. Formação litúrgica mistagógica. 
experiência do humano com o divino a mera execução de ritos como prescrição disciplinar. Se a religiosidade popular pode adentrar pelos caminhos do mundo mágico, também as liturgias podem padecer do mesmo erro, tornando a celebração repetição mecânica sem comunicar o mistério. $\mathrm{O}$ mesmo vale para os ritos catecumenais, os quais precisam estar em constante movimento de inculturação. A uniformidade da celebração, que não leva em conta a cultura não tem força para comunicar o mistério. Portanto, a eficácia da ritualidade catecumenal em muito depende do esforço de inculturação. 


\section{CONCLUSÃO GERAL}

Refletir, dialogar e aproximar duas instituições fundamentais da Igreja e dignamente reconhecidas por ela foi o objetivo maior da tese, intitulada 'Paróquia e iniciação cristã: uma relação urgente. A interdependência entre renovação paroquial e mistagogia catecumenal'.

Trata-se de uma instituição bimilenar, a paróquia, e a outra, também bimilenar, contudo perdida ao longo da história e, hoje, resgatada pelo Concílio Vaticano II: a iniciação cristã catecumenal. Ambas representam os grandes desafios pastorais da atualidade: a transmissão da fé às novas e futuras gerações e a configuração comunitária da fé. Não é difícil perceber a dificuldade de iniciar na fé na atualidade quando já não é mais natural ser cristão, assim como é desafiador perseverar na vivência cristã em comunidade quando cresce o assim chamado processo de desistitucionalização religiosa, ou a crença sem pertença. Exemplo mais plausível desta realidade pode ser encontrado na nova realidade familiar, ou ainda no mundo juvenil, cujo índice de desistitucionalização cresce em ritmo acelerado.

Contudo, engana-se quem pensa estar tão somente no cultural os desafios dessas duas instituições. Afirmamos enfaticamente ao longo da pesquisa que ambos, paróquia e iniciação cristã, sentem os desafios externos e internos. De dentro e de fora provêm entraves que nem sempre favorecem a vivência e a transmissão da fé. Sobre as dificuldades advindas do cultural, todo o primeiro capítulo do trabalho se dedicou a situar a temática no seio da cultura hodierna. Vale lembrar que reside aí, na mudança de época, igualmente possibilidades inéditas para a evangelização.

No tocante aos desafios internos na transmissão e vivência da fé, oriundos da própria realidade eclesial, os capítulos subsequentes se responsabilizam em evidenciar o esgotamento de paradigma tradicional de catequese, e o cansaço do vigente modelo paroquial. A contribuição maior desses capítulos estão em ter evidenciado a necessidade e pertinência de um novo paradigma de iniciação cristã, kerigmático e mistagógico, que substitua a tradicional catequese abstrata, conceitual e, por vezes, moralista. É no catecumenato onde melhor podemos visualizar o surgimento ou reaparecimento deste novo paradigma. Resgatado pelo 
Concílio Vaticano II, e publicado no Ritual de Iniciação Cristã, ele constitui, na atualidade, um vigoroso instrumento de renovação catequética.

A paróquia, por sua vez, nascida no século quarto, já nos ares da cristandade, praticamente se mantém imutável após dezessete séculos. Fato é que o modelo atual de paróquia não é um instrumento feliz para a transmissão da fé, pois tende mais a alimentar a fé dos que já estão nela do que fazer-se missionária e gerar novos cristãos. Tentativas de renovação paroquial não são de hoje. A passos lentos ela vem buscando nova configuração, pertinente à cultura hodierna. Não nos é permitido anular as riquezes presentes na instituição paroquial, apesar de sua crise estrutural. Destacamos como positivo da estrutura paroquial, sua abertura a todos, sem elitismo; sua referência religiosa, sua força simbólica e real de que ainda é portadora, embora não como no passado.

Evidenciamos e justificamos, assim, nos primeiro capítulos da pesquisa, a necessidade de refletir sobre os temas em questão. Contudo, afirmamos categoricamente que o mais importante do que estudar as duas realidades, é aproximá-las, abordá-las conjuntamente. Consolidação/implantação da prática catecumenal e novo rosto de paróquia não podem ser buscas e sonhos paralelos, mas, ao contrário, tarefas complementares de um único projeto evangelizador, pois eles se dependem e se iluminam mutuamente. A isso chamamos de relação dialética. Há entre as duas instituições uma cumplicidade pastoral, uma responsabilidade mútua, uma interferência recíproca, na qual a vitalidade de uma depende do fortalecimento do outra.

A pedagogia catecumenal lança luzes para a renovação paroquial, e a paróquia em renovação é decisiva para o êxito e a consolidação catecumenal, pois este necessita de uma configuração eclesial adequada a sua proposta pastoral. Não são a restauração do catecumenato, um decreto, a publicação do RICA que garantirá a eficácia catecumenal, ou resolverá os desafios da transmissão da fé. Sem estruturas eclesiais renovadas, adultas, o catecumenato não passará de um objeto estranho no seio da Igreja.De um lado, a prática catecumenal se faz dependente de uma nova estrutura paroquial, por outro, ele a questiona, a promove, a ilumina. Trata-se, portanto, de um processo dialético. Analogicamente, podemos afirmar que assim como a caminhada da iniciação cristã catecumenal é progressiva e processual, formada por tempo e etapas, 
também a renovação paroquial e consolidação catecumenal são processuais, isto é, são frutos de um processo dialético, de uma relação na qual um não somente depende do outro, mas a promove. Portanto, diante da tentação da pergunta pelo que vem primeiro: a realização catecumenal que mudará a paróquia, ou a paróquia renovada que melhor acolherá o catecumenato e o consolidará, buscamos responder na pesquisa, por meio do diálogo entre as duas instituições, que nem um nem outro, ou melhor, os dois movimentos se realizam necessariamente juntos, como uma engrenagem, num movimento de peças articuladas.

Os elementos da pedagogia catecumenal colocam a paróquia em movimento, em renovação e neste movimento renovador, o paradigma catecumenal é melhor absorvido e assimilado pela estrutura paroquial. Dito com outras palavras, a paróquia em renovação irá melhor assimilando, em sua estrutura, nas artérias de sua configuração, os elementos catecumenais Tomemos alguns exemplos: a riqueza dos ministérios eclesiais presentes na iniciação cristã catecumenal provoca e ilumina uma reforma ministerial paroquial, uma maior abertura a novos ministérios. Ao mesmo tempo, essa mesma riqueza de ministérios catecumenais que provoca na paróquia uma nova estrutura ministerial depende, na prática, de uma paróquia com profunda consciência missionária. Outro exemplo desta relação dialética entre catecumenato e paróquia pode ser buscado na mistagogia catecumenal, que impulsiona a paróquia a desburocratização, a maior espiritualidade. Ao mesmo tempo, esse vigor mistagógico do catecumenato não será levado a cabo sem uma estrutura paroquial flexível, humana, acolhedora, por issmo mesmo, mistagógica, ou seja, o catecumeanto será mistagógica a medida que a paróquia, os agentes, os ministérios e ministros, o ambiente, a acolhida forem mistagógicos.

Norteou o diálogo entre as duas instituições em questão os tempos do processo catecumenal, isto é, a partir de cada fase da iniciação cristã catecumenal buscamos os elementos paróquias que melhor correspondem aquela etapa, para, então estabelecer a conversa. O pré-catecumenato remete, dentre outros elementos, à missão e à acolhida paroquial. O catecumenato, tempo de formação mais intensa se aproxima da formação permanente na paróquia, ou se preferirmos, do catecumenato permanente. Iliminação/purificação, tempo de intensa preparação, retiro quaresmal, remete à conversão pastoral e estrutural. Conversão 
paroquial a que ou em que? Respondemos que em síntese a paróquia é convocada à conversão à mistagogia. Mistagogia, a última etapa do processo catecumenal, do mesmo modo que não é só uma etapa da formação cristã, mas a tônica de toda a caminhada, assim também a mistagogia na estrutura e nas pastorais paroquial não é algo que na paróquia se oferece aos fiéis, mas aquilo no qual ela mesma é chamada a se converter, a se tornar, para então ser experimentada como lócus da mistagogia.

Importa perceber que nosso objetivo não foi o catecumenato em si, nem a instituição paroquial, cujas realidades por si só já são possibilitadoras de muitos estudos e reflexões. O objetivo maior da pesquisa foi a relação entre as duas instituições, cientes da profunda aproximação entre elas. Para a construção desta relação dialética foi preciso percorrer um longo caminho. Nosso percurso começou, como já salientamos há pouco, com um olhar à cultura contemporânea. Conhecer o hoje da história é premente para qualquer empreendimento teórico ou prático, ainda mais quando o assunto é evangelização. Portanto, como pano de fundo da tese, entramos no terreno da cultura hodierna, por muitos denominada pós-moderna, que, no entanto, para além da exatidão conceitual, trata-se de uma mudança epocal que provoca, desestabiliza, tira a paróquia e a iniciação cristã da zona de conforto. Muitos elementos culturais foram destacados, oportunizando e/ou dificultando a transmissão e a vivência da fé. Está em alta o indivíduo, a escolha, o hoje. Afirma-se a centralidade do indivíduo, a necessidade da experiência e da subjetividade. Se isso pode de certa forma ser um desafio é também uma possibilidade para a transmissão da fé.

Com os pés assentados no hoje da história pudemos melhor avançar na pesquisa. Refletimos, então, no segundo capítulo a problemática (o status questionis) da iniciação à vida cristã: desafios, possibilidades, natureza e identidade. A contribuição maior do capítulo esteve em evidenciar a passagem em andamento do paradigma tradicional de transmissão da fé para a crescente consciência e descoberta de um novo jeito de iniciar na vida cristã. Insistimos no fato de que a atual realidade faz um conte histórico no tocante à transmissão da fé, agora não mais realizada com o suporte cultural, o que requer da Igreja maior clareza missionária e novos pressupostos para a transmissão da fé, o que já está em andamento desde as ultimas décadas. 
No terceiro capítulo mergulhamos na reflexão sobre a concretização (visibilidade) mais evidente do novo paradigma da iniciação à vida cristã: o catecumenato. Novo em termos, pois a novidade está no resgate, na recuperação de um gigante adormecido ao longo da história da Igreja. Afirmamos categórica e repetidamente que o catecumenato é uma proposta privilegiada para iniciar na fé, o caminho que melhor conduz à maturidade cristã ontem e hoje. Justifica-se, portanto, o resgate pelo Concílio Vaticano II do Catecumenato Antigo, uma Instituição eclesial que melhor conseguiu iniciar na fé cristã homens e mulheres adultos, num contexto que em muito se assemelha aos dias atuais, 'onde cristãos não nascem mas se tornam'. Apresentamos o itinerário catecumenal apresentado pelo Ritual de Iniciação Cristã de Adultos (RICA), fruto de uma atualizaçãoresgate litúrgico-pastoral de uma Igreja que sente a urgência da missão em tempos de mudança de época, ciente de que o modelo tradicional de transmissão da fé não se justifica mais.

Após um longo período de inverno catecumenal, o aggiornamento do Concílio Vaticano II soube com sabedoria olhar para os sinais dos tempos sem desviar o olhar da fonte. O Vaticano II resgata e se apropria do patrimônio teológico litúrgico pastoral da Igreja primitiva, bebe das fontes patrísticas, não numa atitude de saudosismo, nem repetição mimética, mas como inspiração, consciente da necessidade de devidas adaptações. Por várias vezes utilizamos a expressão pedagogia catecumenal, o que não quer significar repetição da metolodologia dos primeiros séculos, mas inspiração para a elaboração de novos itinerários para iniciar na fé. Vale lembrar o que diz o estudo 97 da CNBB quando afirma que o modelo catecumenal "não é um projeto fechado para ser seguido ao pé da letra em todas as situações. Há muita possibilidade - e certamente haverá necessidade - de adaptações, soluções locais criativas, maneiras de conviver com eventuais carências" ${ }^{\prime 688}$. Dito diferente, a partir dos alicerces da Patrística, buscase atualizá-lo e adaptá-lo através de uma hermenêutica dos sinais dos tempos.

Qual o modelo de comunidade eclesial, ou mais especificamente, de paróquia, capaz de levar a cabo a proposta catecumenal? Existem tais comunidades ideais? Com esta pergunta subjacente, iniciamos a segunda parte da

${ }^{688}$ CONFERÊNCIA NACIONAL DOS BISPOS DO BRASIL. Iniciação à vida cristã: um processo de inspiração catecumenal, op, cit., $n$. 159. 
pesquisa. Na mesma dinâmica do capítulo sobre a iniciação à vida cristã, no qual pudemos conhecemos os principais elementos pastorais e teológicos da iniciação cristã, adentramos no histórico da paróquia, sua identidade, natureza, deficiência e seu pertinência. Se o vigente modelo paroquial apresenta sérias limitações pastorais e estruturais, é bem verdade que não são de hoje os esforços para reestruturá-la, embora os resultados se apresentam lentos.

Concluído, então, o quarto capítulo, iniciamos a relação entre iniciação catecumenal e instituição paroquial. No jogo dialético, ou se preferimos, na contribuição catecumenal à paróquia e desta àquela, veio à luz mais uma vez a grandeza da proposta do catecumenato, sua atualidade pastoral e pedagógica, e ao mesmo tempo, pudemos desmistificá-lo, relativizá-lo, ante certos condicionamentos pastorais e estruturais.

Não obstante sua riqueza, o catecumenato deve ser relativizado por três motivos: necessita de estruturas eclesiais renovadas; a existência de alguns limites existentes nele; e sua lenta implantação-realização, de depende da aceitação e esforço em colocá-lo em prática, o que em nada diminui a grandeza de sua proposta pastoral, ao contrário, o enriquece, pois mostra não tratar-se de uma peça isolada no conjunto eclesial. Afirmar ser o catecumenato uma pedagogia privilegiada para iniciar na fé não significa estar nele a solução para o desafio da transmissão da fé. A implantação/consolidação do catecumenato é algo em construção, assim como a renovação paroquial encontra-se nesse mesmo processo.

A paróquia não será uma nova estrutura eclesial de um dia para o outro. Da mesma forma que não é o decreto da restauração do catecumenato que o fará ser catecumenal, não será a declaração de uma nova paróquia que a fará ser nova. Trata-se de um processo lento, em que estão envolvidas diversas dimensões. Aqui e acolá vemos realidades paroquiais bastante avançadas nessa jornada de renovação eclesial, assim como, em muitas paróquias encontramos genuínos processos de iniciação cristã catecumenal. Temos percebido que quando a iniciação cristã catecumenal vai bem, a paróquia também vai bem. O contrário é igualmente verdade. Em paróquias em renovação, o catecumento se apresenta vigoroso. 


\section{Referêncais bibliográficas}

\section{INICIAÇÃO À VIDA CRISTÃ e LITURGIA}

ALBERICH, E. A catequese no contexto do Concílio Vaticano II e pós-concílio. In: Revista de Catequese. São Paulo: Unisal, n. 61, jan/mar 1993 (pp. 15-26).

A catequese tem futuro? In: Revista de catequese, v. 28, n. 109, janeiro/março, 2005 (pp. 22-28).

Modelos de catequese com adultos. In: Revista de cateques, ano 25, $\mathrm{n}$.

$97,2002$.

ALBERICK, E.; BINZ, A. Catequese com adultos: elementos de metodologia. São Paulo: Salesiana, 2001.

ALDAZÁBEL, J. Funciona la comunicación en nuestras celebraciones. In: Phase, $n$. 107, 1978 (pp. 459-478).

. Gestos e símbolos. São Paulo: Loyola, 2005.

AMADO, J. P. Catequese num mundo em transformação: desafios do contexto sóciocultural, religioso e eclesial para a iniciação cristã. In: Revista de Catequese, ano 32, n. 128, outubro/dezembro, 2009.

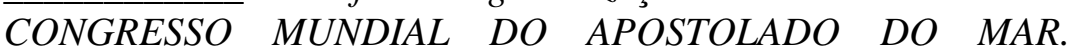

Viver e transmitir a fé no mundo urbano. In: CELAM. Testigos de Aparecida_. Secretaria Geral. Bogotá, 2008.

ANTONIAZZI, A. Perspectivas pastorais a partir da pesquisa. In: SOUZA, L. A; FERNANDES, S. R. A. (orgs.). Desafios do catolicismo na cidade: pesquisa em regiões metropolitanas brasileiras. CERIS. São Paulo: Paulus, 2002.

. Uma leitura teológico-pastoral. In: Valle, E. (org.). Padre: você é feliz? Uma sondagem psicossocial sobre a realização pessoal dos presbiteros do Brasil. Brasília: CNBB; CNP; Loyola, 2003.

AUGÉ, M. Liturgia. História, celebração, teologia e espiritualidade. São Paulo: Ave Maria, 1992.

BASURKO, X. De Gregório Magno a Gregório VII (590-1073). In: BOROBIO, D. (org.). A celebração na Igreja 1: liturgia e sacramentologia fundamental. São Paulo: Loyola, 1990.

O culto cristão na Igreja o Império (313-590). In: BOROBIO, D.

(Org.). A celebração na Igreja 1: Liturgia e sacramentologia fundamental. São Paulo: Loyola, 1990.

BASURKO, X; GOENAGA, J. A vida litúrgico-sacramental da Igreja em sua evolução histórica. In: BOROBIO, D. (org). A celebração na Igreja 1: liturgia e sacramentologia fundamental. São Paulo: Loyola, 1990.

BERNARDINO, A. (org). Dicionário de Patrística e Antiguidades Cristãs. Petrópolis: Vozes, 2002. 
La dimensione missionária della catechesi: Il convegno ECC nel cuore della problemática del primo annuncio. Catechesi, v. 78, n. 3, 2008-2009.

BOROBIO, D. Bautismo de niños y confirmación: problemas teológico-pastorales. Fundación Santa Maria: Madrid 1987.

. Catecumenato. In: SARTORE, D e TRIACCA, A. M. (orgs). Nuevo Diccionario de Liturgia. Madrid: Paulinas, 1987.

. Catecumenato e iniciación Cristiana: um desafio para la iglesia hoy. Barcelona: Centre de Pastoral Litúrgica, 2007 (biblioteca litúrgica, 30).

Catecumenato para la evangelización. San Pablo, 1997.

El Catecumenado y su situación el la Iglesia actual. In: Teología y Catequesis.San Dámaso: Madrid, 2002.

. Celebração na Igreja. Vol II. Os sacramentos. São Paulo: Loyola, 1993.

La iniciación Cristiana. Salamanca, Ediciones Sigueme, 1996.

BRESSAN, L. Parroquia y catequesis. In: Sinite. Revista de Pedagogía Religiosa. Madrid: Lasalle, vol. LIII, n. 159-160, enero-agosto 2012 (pp.223-238).

CABIÉ, H. V. A iniciação cristã. In: MARTIMORT, A. G. A Igreja em oração. Introdução à liturgia. Petrópolis: Vozes, 1991 (Volume 3 - Os sacramentos).

CARMO, S. M. Catequese num mundo pós-cristã: estudo do terceiro paradigma catequético formulado por Denis Villepelet. Tese doutoral. FAJE: Belo Horizonte, 2012.

CASTELlANO, J. La iniciación Cristiana y el camino espiritual". In: Phase. Barcelona, v. 61, n. 246, 2001 (pp. 461-576).

CATÃO, F.; REIS, E. M. Oração e catequese com adultos. In: Revista de catequese. São Paulo: Unisal, ano 27, n. 108, dezembro/outubro, 2004.

CAVALLOTO, G (org.) Iniziazione cristiana e catecumenato. Bologna: EDB, 1996.

CHUPUnGO, A. Adaptação. In: SARTORE, D. \& TRIACCA, A. M. (orgs). Dicionário de Liturgia. São Paulo: Paulinas, 1992.

CODINA, V; IRARRAZAVAL, D. Sacramentos de iniciação: água e espírito de liberdade (col. Teologia e Libertação) Petrópolis: Vozes, 1988.

DOWNS, T. A journey to self through dialogue: an excursion of spiritual selfdiscovery for individuals and groups.

DUJARIER, M. The Rites of Christian Initiation: historical and pastoral relections. Chicago: Sadlier, 1979.

A Survey of the History of the Catechumenate. In: Becoming a catholic christian: a Symposium on Christian Initiation. New York: Sadlier, 1981 (pp.19-38). 
Le parrainage des adultes aux trois premiers siécles de l'Eglise. Recherche historique sur l'évolution et des étapes catéchuménales avant 313. Cerf: Paris, 1962.

DUNNING, J. The stages of initiation: parte I. Inquiry. In: Becoming a catholic christian: a Symposium on Christian Initiation. New York: Sadlier, 1981 (pp.19-38).

FALSINI, R. L'iniziazione Cristiana e i suoi sacramenti. Ed. O.R, Milão, 1986.

FIGUEIREDO, F. A. Curso de Teologia Patrística I: a vida da Igreja primitiva (séculos I e II). Petrópolis: Vozes, 1983.

FLORISTÁN, C. Controversias sobre el bautismo de niños. In: Fhase 10, 1970. 1995. . Catecumenato: história e pastoral da iniciação. Petrópolis. Vozes, La iniciación Cristiana. In: Phase, 171, 1989.

FOSSION, A. Reconstruindo a catequese em tempos de crise: rumo a comunidades catequizadas e catequizadoras. In: Revista de catequese, ano 29, n. 115, julho/setembro, 2006 (pp. 16-26).

FOSSION. La catéchèse dans le champ de la communication: sés enjeux pour l'inculturation de la foi. Paris: Cerf, 1990.

FREDERICI, T. La mistagogia della Chiesa. In: ANCILLI, E. (ed.). Mistagogia e direzione spirituale. Roma/Milano: Teresianum, 1985 (pp. 163-245).

GOEDERT, V. M. Batismo e missão. In: SILVA, J. A.; SIVINSKI, M. (orgs). Liturgia. Um direito do povo. Petrópolis: Vozes, 2001.

GRUEN, W. Novos sinais dos tempos para o cultivo da fé. In: Perspectiva Teológica, v.36, n. 100, 2004.

GY, P. M. Quam primum. Note sur Le baptême des enfants. LMD 32, 1952.

IVORY, T. The Stages of Iniciation. II. The Catechumenate. In: Becoming a Catholic Christian. New York: Sadlier, 1981 (pp. 199-218).

KENP, R. A journey in faith: an experience of the catechumenate. Chicago: Sadlier, 1979 (Christian Initiation, 3).

LAMARCHE, D. Le baptême, une iniciation? Paulines-Cerf, Paris 1984.

LAURENTIN A.; DUJARIER M. Catéchuménat. Données de h'histoire et perspectives nouvelles (Vivante Liturgie 83). Paris, 1969.

LELO, A. F. A iniciação cristã no Brasil. In: Revista de Catequese. São Paulo: Unisal, ano 27, n. 107, julho/setembro, 2004 (pp. 5-18).

. Iniciação: processo profundamente humano, intinerário de fé, caminho litúrgico, iniciação aos mistérios'. In: Ciberteologia. Revista de Teologia \& Cultura, n. 7, ano II - setembro/outubro 2006.

LEÓN OJEDA, F. J. La iniciatión Cristiana. Publicationes CELAM Bogotá, Missión Continental 2. 
LIÉGE, A. O que é catequese? In: ISPAC (Instituto de Pastoral Catequética da $\mathrm{CNBB})$. Introdução à catequética.

LIMA, L. A. A face brasileira de catequese: um estudo histórico-pastoral do movimento catequético brasileiro. UPS, tese de doutorado, n. 346, Roma, 1995.

. A unidade da catequese e liturgia na iniciação cristã. In: Revista de catequese. São Paulo: Unisal, ano 29, n. 114, abril/junho, 2006 (pp. 34-52).

Catequese a serviço da iniciação cristã: reflexões em torno do tema central da $3^{a}$ Semana Brasileira de Catequese. In: Revista de Catequese, ano 32, n. 128, outubro/ dezembro, 2009 (pp.15-25).

Com adultos, catequese adulta: uma proposta brasileira. In: Revista de Catequese, ano 24, abril/junho, 2001.

Novos paradigmas para a catequese no Brasil: apresentando o DNC. Novos paradigmas para a catequese no Brasil: apresentando o DNC. Horizonte Teológico, v. 6, n. 11, 2007.

- VII Assembléia ordinária de SCALA. Iniciação à vida cristã : paradigma de transmissão da fé.

13 Encontro Nacional de Presbíteros. 03 a 09 de fevereiro de 2010, Itaici, Indaiatuba - SP. Iniciação à vida cristã: Tema prioritário da $47^{\mathrm{a}}$ Assembleia Geral da CNBB (abril 2009) e da III Semana Brasileira de Catequese (outubro 2010 Prot. $15 / 2010$ - $13^{\circ}$ ENPPe).

Novos paradigmas para a Catequese no Brasil. In: Revista de Catequese. v. 30, n. 117, janeiro/março, 2007 (pp. 06-17).

LOPES, J. Catecumenato. In: FIORES, S. G. T. (org). Dicionário de Espiritualidade. São Paulo: Paulus, 1998.

MAZZA, E. La mistagogia. Una Teologia della Liturgia in época patrística. Roma: Edizioni liturgiche, 1988.

MEEKS, W. A. Os primeiros cristãos urbanos: o mundo social do apostolo Paulo. São Paulo: Paulus, 1992 (Coleção Bíblia e sociologia).

MERLOS, F. O Ritual de Iniciação Cristã de Adultos (Rica): uma leitura teológica. In: Revista de Catequese, ano 25, n. 99, julho/setembro 2002.

MOUROUX, J. L'expérience chrétienne. Paris, 1954.

MOVILLA, S. Educación de la fe y comunidad Cristiana. Madrid, 2001.

NEUNHEUSER, B. O Catecumenato. In: BARAÚNA, G. (org.) A sagrada liturgia renovada pelo Concílio. Petrópolis: Vozes, 1964.

NOCENT, A. Iniciação cristã (Evolução histórica da iniciação cristã). In: SARTORE D. \& TRIACCA A. M. (orgs.). Dicionário de Liturgia. São Paulo: Paulinas, 1992.

NOCKE, F. J. Doutrina específica dos sacramentos. In: SCHNEIDER, T. Manual de dogmática. Vol. 2, 2 ed. Petrópolis: Vozes, 2002.

NOVAK, M. G. (trad.); GIBIN, M. (intr.) Tradição Apostólica de Hipólito de Roma. Liturgia e Catequese em Roma no século III. 2 ed. Petrópolis: Vozes, 1981. 
OLIVERIA, R. M. O movimento catequético no Brasil. São Paulo: Salesiana, 1980.

ONÃTIBIA, I. La Catequesis litúrgica de los Padres. In: Phase 20, 1980, pp. 281 294.

ORMONDE, D. Vale a pena os catequistas conhecerem o catecumenato. In: CONFERENCIA NACIONAL DOS BISPOS DO BRASIL. Segunda Semana Brasileira de Catequese. Com adultos, catequese adulta (Estudos da CNBB, 84).

setembro/outubro, 2003.

O tempo da purificação e iluminação. In: Revista de Liturgia,

PAIVA, V. Catequese e liturgia, duas faces do mesmo mistério. São Paulo: Paulus, 2008.

PASQUALETTI, G. Reforma litúrgica. In: SARTORI, D. e TRIACCA A. M. (org.) Dicionário de Liturgia. São Paulo: Paulinas, 1992.

PASTORINO, M. A. De uma pastoral de mantenimiento, a una pastoral misionera: apuntes para el encuentro de responsables laicos de montevideo. 27 de setiembro de 2009. Disponível em: www.arquidiocesis.net/.../MisionMontevideo/deUna...

RODRIGUEZ, J. M. La catequesis al serviço de la iniciación cristiana. Acoforec: Bogota, 2006.

RODRIGUES, S. A. A relação liturgia e catequese a partir do Ritual da Iniciação Cristã de Adultos. São Paulo: Pontifícia Faculdade de Teologia Nossa Senhora de Assunção. Dissertação Mestrado, 2007.

SANTANA, L. F. Batizados no Espírito.

SARTORE, D. Catechesi e liturgia. In: SARTORE, D; TRIACCA, A. M (Eds). Nuevo dizionario de liturgia. Cinisello Balsamo. Paoline, 1988.

SEGURA, M. A. J. Necessidade do Primeiro Anúncio na formação de catequistas. In: Revista de Catequese. São Paulo: Unisal, v. 29, n. 114, abril/junho, 2006 (pp. 28$33)$.

SILVA, J. A. A evolução cristã em sua evolução histórica: alguns apontamentos para estudo.

. A. Relação entre Catequese e Liturgia. Uma visão histórico-teologico geral. In: SIVINSKI, M, e SILVA, J. A (orgs). Liturgia no coração da vida. São Paulo: Paulus, 2006.

SOBRERO, J. Catequesis mistagógicas: un modelo del siglo V para hoy. In: Phase 33, 1993 (pp. 181-194).

TABORDA, F. Nas fontes da vida cristã: uma teologia do batismo-crisma. 2. Ed. São Paulo: Loyola, 2009.

VELASCO, M. J. A experiência cristã de Deus. São Paulo: Paulinas, 2001. (Mística Cristã).

Sal Terrae, 2002.

. La transmisión de la fe en la sociedade contemporânea. Santander: 
VAZ, H. C. A experiência de Deus. In: BETTO, F. et alli. Experimentar Deus hoje. Petrópolis: Vozes, 1976.

ZILLES, U. (trad). Didaqué: catecismo dos primeiros cristãos. In: Col. Fontes da catequese, 1. Petrópolis: Vozes, 1988.

\section{PARÓQUIA}

AGUIRRE, R. Del movimiento de Jesús a la Iglesia Cristiana: ensayo de exégesis socilógica del cristianismo primitivo. Estella: Verbo Divino, 2009.

ALMEIDA, D. B. A pastoral na virada do milênio. In: CALAMAN, C. (org.). A sedução do sagrado: o fenômeno religioso na virada do milênio. Petrópolis: Vozes, 1998.

ALMEIDA, J. A. Leigos em quê? Uma abordagem histórica. São Paulo: Paulinas, 2006.

Modelos eclesiológicos e ministérios eclesiais. In: Revista Eclesiástica Brasileira. Petrópolis: Vozes, v. 48, fasc. 190, junho, 1988 (pp. 310-352). Paróquia, comunidades e pastoral urbana. São Paulo: Paulinas,

2009.

Por uma Igreja ministerial: os ministérios ordenados e não ordenados no 'Concílio da Igreja sobre a Igreja. Revista de Teologia e Cultura / Journal of Theology \& Culture. Edição n. 0, ano I, abril/maio/junho 2005. http://ciberteologia.paulinas.org.br/ciberteologia/index.php/artigos/por-uma-igrejaministerial-os-ministerios-ordenados-e-nao-ordenados-no-concilio-da-igreja-sobre-aigreja/

ALMEIDA, M. A. et all. In: LONDOÑO, F. T. (org.). Paróquia e comunidade no Brasil. São Paulo: Paulus, 1997.

AMADO, J. P. Deus e a Cidade: chances e desafios para a experiência cristã de Deus em contexto condominial. Tese doutorado em Teologia. PUC/RJ Pontifica Universidade Católica, 1999.

Experiência eclesial em mundo urbano ( $1^{o}$ parte). In: Atualidade Teológica. Revista Semestral do Departamento de Teologia da PUC-Rio. Ano V, n. 8, janeiro/junho 2001.

Experiência eclesial em mundo urbano ( $2^{\circ}$ parte). In: Atualidade Teológica. Revista Semestral do Departamento de Teologia da PUC-Rio, ano V, n. 9, julho/dezembro 2001.

Igreja \& comunidades - Aspectos pastorais (texto não publicado)

AMERINDIA (org.). Sinais de esperança: reflexão em torno dos temas da Conferência de Aparecida. São Paulo: Paulinas, (Coleção Sinais dos Tempos), 2007.

ANDRADE, D. R. Reiventar a paróquia? Sonhar em tempo de incertezas. São Paulo: Loyola, 2006. 
ANTONIAZZI, A. Uma leitura teológico-pastoral. In: VALLE, E. (org.). Padre: você é feliz? Uma sondagem psicossocial sobre a realização pessoal dos presbíteros do Brasil. Brasília: CNBB; CNP; Loyola, 2003 (pp. 118-142).

AUBRY, A. Una Iglesia sin parroquias. Siglo XXI: México, 1974.

AZEVEDO, W. O. Paróquia, cidade e evangelização. In: Rhema, Belo Horizonte, 1997.

BASSINI, P. F. Paróquia, rede de comunidades. In: Vida Pastoral. Revista bimestral para sacerdotes e agentes de pastoral, ano, 52, n. 279, julho-agosto de 2011.

BENEDETTI, L. R. A mudança de época como desafio aos presbíteros. In: Revista Medellín (teologia y pastoral para América latina), vol. XXXVI, n. 141. EneroMarzo, 2010 (pp. 25-42).

BENELLI, S. J. Modelos de presbítero no contexto católico. In: Fragmentos de Cultura. Goiânia, v. 19, n. 5/6, maio/jun. 2009 (pp. 369-389).

BESTARD, J. La Parroquia, institución Eclesial isustituible e insuficiente. In. Phase. Revista de Pastoral Liturgica, julio-agosto, n. 208, 1995 (pp. 267-280).

BO, V. Parrocchia tra passato e futuro. Assis, 1977.

BOFF, L. Experimentar a Deus hoje. In: Frei BETO et all. Experimentar Deus hoje. Petrópolis: Vozes, 1974.

BONHÖFFER, Zur Tauffrage. Ein Gutachten. In: Gesammelte Schriften. Munique, III, 1960 (pp.431-454).

BORRAS, A. Appartenance à l'Église ou itinérance ecclesiale? (Pertença à Igreja ou itinerância eclesial? Lumen Vitae, v. 48, n. 2, juin 1993 (pp. 161-173).

A remodelação paroquial. In: BORRAS, A.; ROUTHIER, G. A nova paróquia. Gráfica de Coimbra 2.

Le communautés paroissiales: droit canoniques et perspectives pastorales: Paris: Cerf, 1996.

BORRAS, A.; ROUTHIER, G. A Nova Paróquia. Gráfica de Coimbra 2.

BOROBIO, D. Comunidad eclesial y ministerios. In: Phase. Revista de Pastoral Liturgica. Barcelona, v. 38, fasc. 228, 1998, (pp. 461-486).

BRAMBILLA, F. G. La parrocchiaa oggi e domani. Assisi: Editrice, 2004.

BRESSAN, L. Cos'è (oggi) la parrrocchia. In: Ripensare la parrocchia. Bologna: EDB, 2004.

2004.

La parrocchia oggi: identità, transformazioni, sfide. Bologna: EDB,

BRIGHENTI, A. Para uma recepção criativa da proposta missionária de Aparecida. In: Encontros Teológicos. ITESC. Florianópolis-SC, 2008.

CABALlERO, B. Bases de una nueva evangelización. Madrid: Paulinas, 1993.

CALAMAN C. ANTONIAZZI, A. A Pastoral Católica: do primado da instituição a 
primado da pessoa. In: ANJOS, M. A. (orgs.). Sob o fogo do Espírito. São Paulo: Paulinas, 1998.

CALDENTEY, J. Significado das Comunidades Cristãs de Base para a Igreja. Concilium: Revista Internacional de Teologia. Petrópolis: Vozes, v. 11, fasc. 104, 1975 (pp. 466-482).

CAPPEllaro, J. et alli. Comunione di comunitá. Progetto parrochia. 2 ed. Assis, 1990.

CASTELLUCCI, E. Essere comunità Cristiana oggi. In: Nuove forme di comunità Cristiana: Le relazioni pastorali tra clero religiosi, laici e território. Centro orientamento pastorale. $60^{\circ}$ Settimana nazionele di aggiornamento pastorale. Bolongna: EDB, 2010.

CASTILLO, J. M. La comunidad y los ministérios: análisis histórico-bíblico In: Pastoral Misionera, v. 5, ano 14, julio-agosto 1978 (pp. 35-45).

CATÃO, F. Teologia e experiência. In: ANJOS, M. F (org.). Experiência religiosa: risco ou aventura? São Paulo: Paulinas, 1998.

CAVAlCANTI, T. O Método de Leitura Popular da Bíblia na América Latina. A contribuição de Carlos Mesters. Tese de Doutorado em Teologia pela PUC do Rio de Janeiro, 1991.

CODINA, V. A missão como renovação eclesial. In: BRIGHENTI, A.; HERMANO, R. (orgs). A missão em debate: provocações à luz de Aparecida. São Paulo: Paulinas, 2010 (Coleção Ecclesia 21).

COMBLIN, J. As grandes incertezas da Igreja atual. In: Revista Eclesiástica Brasileira. Petrópolis: Vozes, v.67, fasc. 265, jan/mar 2007.

A Paróquia ontem, hoje e amanhã. In: A paróquia ontem, hoje e amanhã. Simpósio. Petrópolis: Vozes, 1967.

Nota a propósito de Igreja e sociedade urbana: In: Urbanização e evangelização. Porto Alegre: Cadernos da ESTEF - 5.

Olhando para o horizonte. In: Revista Eclesiástica Brasileira, v. 65, fasc. 260, 2005 (pp.831-857).

. Os desafios da cidade no século XXI. 2.ed. São Paulo: Paulus, 2002.

1999.

Pastoral urbana: o dinamismo na evangelização. Petrópolis: Vozes, Teologia da cidade. São Paulo: Paulinas, 1991.

CONGAR, Y. Misión da la parroquia. In: Sacerdocio y laicado. Estela: Barcelona, 1964 (original de 1948). Vraie et fausse reforme dans l'Église. Paris: Cerf, 1968.

CONNAN F. e BARREAU C. La parroquia de mañana. Studium: Madrid, 1970.

COUTINHO, S. R. CEBs e "pequenas comunidades": identidades e diferenças. In: OROFINO, F. et alli. (orgs.). CEBs e os desafios do mundo contemporâneo. Iser Assessoria. São Paulo: Paulus, 2012 (pp. 86-87). 
COZZENS, D. B. A face mutante do sacerdote: reflexões sobre a crise de alma do sacerdote. Tradução de C. C. Bartalitti. São Paulo: Loyola, 2001.

DEELEN, G. Pode a paróquia urbana ser uma comunidade? In: Revista Eclesiástica Brasileira. Petrópolis: Vozes, v. 25, fasc. 97, 1965.

DOMEZI, M. C. A paróquia desafiada a ser comunidade de comunidades. In: LONDOÑO, F. T. Paróquia e comunidades no Brasil: perspectiva histórica. São Paulo: Paulus, 1997.

DUTRA, S. G. A paróquia na cidade. Análise de algumas contribuições da "Teologia da Cidade" para a superação da mentaliade da paróquia territorial-ruraltridentina. Pontifícia Universalidade Lateranense. Roma, 2000-2001.

ESTEVEZ, L. Leadership femminile nelle comunità dell'Asia Minore. In: VALÉRIO, A. (ed). Donne e Bibbia: storia ed esegesi. Bologna: EDB, 2006.

FLORISTÁN, C. Para compreender a paróquia. Gráfica de Coimbra.

FUELLENBACH, J. Igreja, comunidade para o Reino. São Paulo: Paulinas, 2006.

GAMO, M. La parroquia, comunidad impossible. In: AA.VV. Vida Cristiana y compromisso terrestre. V Semana de Teología de la Universidad de Deusto. Mensajero. Bilbao, 1970 (pp. 435-498).

GIUSTINA, E. D. A paróquia renovada: participação do Conselho de Pastoral paroquial. Paulinas: São Paulo, 1986.

GODOY, M. "Paróquias renovadas à luz de Aparecida". In: Vida Pastoral. Revista bimestral para sacerdotes e agentes de pastora, ano 49, n. 261, julho-agosto, 2008.

GREELEY, A. Sociologia e estrutura della Chiesa. In: Concilium: Revista Internacional de Teologia. Petrópolis: Vozes, v. 06, fasc. 58, 1970.

GUIMARÃES, A. R. Comunidades de Base no Brasil. Uma nova maneira de ser Igreja. Vozes, Petrópolis, 1978.

HACKMANN, G. L. B. Por uma paróquia como comunidade evangelizadora e missionária. Teocomunicação. Porto Alegre, março 1996, v. 26, n. 111 (pp. 03-15).

HÖFFNER, J. Comunidad. In: FRIES, H. Conceptos fundamentales de la teología I. Madrid, 1979.

LAURENTIN, R. Luz do Novo Testamento sobre a crise atual dos ministérios. In: Concilium. Revista Internacional de Teologia. Petrópolis: Vozes, v. 08, fas. 80, 1972 (pp. 1242-1251).

LÖHRER, M. A hierarquia a serviço do povo cristão. In: BARAÚNA, G. (org.) A Igreja do Vaticano II. Edição brasileira. Petrópolis: Vozes, 1965.

LOPES, E. Católicos reclusos. Revista Veja, ano 41, n. 48, 3 de dezembro de 2009 (pp. 110-116).

LÓPEZ, S. M. Evangelizar la religiosidad popular. In: Religión y cultura. 257-258. Revista trimestral de lós PP. Agustinos, Provincia de España. Abril-septiembre 2011. Madrid. 
LORSCHEIDER, A. O perfil espiritual e pastoral do presbítero hoje. In: Revista Eclesiastica Brasileira, v. 62, n. 246, abril/junho 2002 (pp. 297-306).

MARGHIGLIONI, E. M.; MEDDI, L. Il futuro della parrochia; guida alle trasformazioni necessarie. Milano: Paoline, 2006.

MELO, A. A. Padres no Brasil: Ontem, hoje, amanhã. In: Revista Eclesiástica Brasileira. Petrópolis: Vozes, fasc. 286, abril, 2012.

MIRANDA, M. F. A eclesiologia do Documento de Aparecida. In: Revista Eclesiástica Brasileira, fasc. 268, v. 67, outubro/dezembro, 2007 (pp. 843-865).

A experiência do Espírito Santo: Abordagem teológica. Perspectiva Teológica. Belo Horizonte, v.30, fas. 81, maio/agosto, 1998 (pp.161181).

A Igreja numa sociedade fragmentada. São Paulo: Loyola, 2003.

Um catolicismo desafiado: Igreja e pluralismo religioso no Brasil.

São Paulo: Paulinas, 1996.

Loyola, 1996.

Um homem perplexo: o cristão na atual sociedade. São Paulo:

Verdades urgentes para uma renovação eclesial. In: Revista Eclesiástica Brasileira, fasc. 289, v. 73, janeiro/março 2013 (pp.125-148).

MIKUSZKA, G. L. Por uma paróquia missionária à luz de Aparecida. São Paulo: Paulus, 2012.

MURGUI, J. M. Parroquia y comunidad en la Iglesia española del posconcilio. Edicep. Valência, 1983.

OLIVEIRA, P. A. R. "CEB: unidade estruturante da Igreja" In: BOFF, C.; LESPAUPIN, I. et all. As Comunidades de Base em questão. São Paulo: Paulinas, 1997.

ORLANDONI, G. Il volto missionário della paroquia. Linee programmatiche per l'anno pastorale 2004-2005.

PANNET, R. La paroisse de l'avenir. L’avenir de la paroisse. Fayard. Paris, 1979.

PEREIRA, E. N. A formação cristã de adultos: o grande desafio para a Igreja do III milênio. Petrópolis: Vozes, 1994.

PEREIRA, J. C. Paróquia missionária à luz do documento de Aparecida. Procedimentos fundamentais. Ed. CNBB, 2012.

Pastoral da acolhida: guia de implantação, formação e atuação dos agentes. São Paulo: Paulinas, 2009 (Coleção discípulo missionário).

PÉRISSET, J. C. Curé et presbyterium paroissial (Analecta Gregoriana, 227). Roma, 1982,

PINEDA. V. M. R. El compromiso misionero del Presbítero. In: Revista Medellín, vol. XXXVI, n. 141. Enero-Marzo 2010 (pp. 43-69). 
REGAN, D. Experiência cristã das comunidades de Base: mistagogia. São Paulo: Paulinas, 1995.

ROUTHIER, G. A paróquia: suas imagens, seus modelos e suas representações. In: BORRAS, A; ROUTHIER, G. A Nova Paróquia. Gráfica de Coimbra 2.

ROUET, A., BOONE, É.; BULTEAU, G.; RUSSEIL J.; TALBOT, A. Un nuovo volto di Chiesa: L'esperienza coraggiosa e innovativa della diocesi di Poitiers. Milano: Paoline, 2007.

. Um Nouveau Visage d'Église. L'expérience dês communautés à Poitiers. Paris: Bayard, 2005.

SANTOS, J. S. Formação de Catequistas para a iniciação à vida cristã. Terceira Semana Brasileira de Catequese. Edições CNBB. Formação iniciática de catequistas. Coleção de subsídios elaborados pela Sociedade de Catequetas Latino-Americana (SCALA).

SEIBOLD, J. Dios habita em la ciuda. Hacia um nuevo paradigma de la Pastoral Urbana em América Latina u el Caribe. Textos da Universidade Ibero-Americana, Congresso Internacional da Pastoral Urbana, México, 2007.

SORAVITO, L. Rinovare la parrocchia a partire dagli adulti: riflessioni e schede de lavoro per operatori pastorali. Milano: Paoline, 2004.

SORAVITO. L.; BRESSAN, L. Il Rinnovamento della parrocchia in uma società che cambia. Padova: Messaggero di Sant'Antonio, 2007.

SUESS, P. "Não tenhais medo!" Da dificuldade de construir a "nova paróquia". In: Revista pastora, ano 55, n. 294, janeiro-fevereiro 2014 (pp. 17-26).

TABORDA, F. Igreja e seus ministros. São Paulo: Paulus, 2011.

TEIXEIRA, F. A fé na Vida: estudo teológico-pastoral sobre a experiência das CEBs no Brasil. São Paulo: Loyola, 1987 (Coleção Fé e Realidade 23).

TÔRRES, M. G. Arte e litúrgica. Tempo, corpo e festa, um simpósio interdisciplinar, numa visão bíblico-teológica. In: Grande Sinal, v. 52, fasc. 03, maio/jun 1998 (pp. 277-283).

URBINA, F. Historia y estructura e la parroquia. In: Pastoral missionera, ano 15, marzo-abril, 1981 (pp. 125-145).

\section{BIBLIOGRAFIA GERAL (TEOLOGIA, CULTURA, ESPIRITUALIDADE)}

AZEVEDO, M C. Não moderno, moderno e pós-moderno. In: Revista de Educação da AEC. Ano 22, n. 89, 1993.

BAUDRILLARD, J. À sombra das maiorias silenciosas. São Paulo: Editoras Brasiliense, 1993.

Las estratégias fatales. Barcelona: Anagrama, 1984.

BAUMAN, Z. Modernidade e Ambivalência. Rio de Janeiro: Jorge Zahar Editor, 1999. Modernidade Líquida, Rio de Janeiro: Jorge Zahar, 2001. 
BENEDETTI, R. L. Pós-modernidade: abordagem sociológica. In: TRASFERETTI, J.; GONÇALVES, P. S. L. (orgs.). Teologia na Pós-modernidade: abordagens epistemological, sistemática e teórica-prática. São Paulo: Paulinas, 2003.

Religião: trânsito ou indiferenciação. In: TEIXEIRA, F.; MENEZES R. (org.). As religiões no Brasil: continuidades e rupturas. Petrópolis: Vozes, 2006.

BERGER, P. L. O Dossel sagrado: elementos para uma teoria sociológica da religião. São Paulo: Paulus, 1985.

BINGEMER, M. C. L. A Experiência do Deus cristão e sua identidade trinitário. In: $O$ mistério e a história: ensaios de teologia em homenagem ao Pe. Félix Pastor, SJ (por ocasião de seus 70 anos). São Paulo: Loyola, 2003 (pp. 87-117).

BOFF, L. A Santíssima trindade é a melhor comunidade. Petrópolis: Vozes, 1988.

BOFF, L. A voz do arco-iris. Brasília: Letraviva, 2000.

CAMPBELL, C. The Romantic Ethic and the Spirit of Modern Consumerism. Oxford: Blackwell, 1987.

CAPRA, F. O ponto de mutação: a ciência, a sociedade e a cultura emergente. 25 ed. São Paulo: cultrix, 1982.

COMBLIN, J. O Espírito Santo e a libertação. Petrópolis: Vozes, 1987.

D'ANDREA, A. F. O self perfeito e a nova era: individualismo e reflexividade em religiosidade pós-tradicionais. São Paulo: Loyola, 2000.

DEBRAY, R. Introduction à la médiologie. Paris: PUF, 2000.

DREIFUSS R. A época das perplexidades. Mundialização, globalização e planetarização: novos desafios. Petrópolis: Vozes, 2001.

ELIADE, M. Iniciaciones místicas. Madrid, 1975.

FRIEDMAN, T. O mundo é plano: uma breve história do século XXI. Rio de Janeiro: Objetiva, 2007.

GIUSTINA, E. D. A Revolução do Terceiro Milênio: humanização da sociedade. Rio de Janeiro: Litteris, 2000.

Aparecida: Santuário, 1993.

GONZÁLES FAUS, J. I. Desafios da pós-modernidade. São Paulo: Paulinas, 1995.

HARVEY, D. Condição Pós-moderna. São Paulo: Edições Loyola, 1992.

HERVIEU-LÉGER, D. Vers un nouveau christianisme? Cerf. Paris, 1987.

O Peregrino e o convertido: a religião em movimento.

Lisboa: Gradiva, 2005.

HAIGHT, R. Dinâmica da teologia. São Paulo: Paulinas, 2004.

IANNI O. A Era do globalismo, Rio de Janeiro: Civilização Brasileira, 1997.

JACOB, C. R. et al. Atlas da filiação religiosa e indicadores sociais no Brasil. Rio de Janeiro/PUC-RJ/Loyola, 2003. 
JEFFERS. Conflito em Roma: ordem social e hierarquia no cristianismo primitivo. São Paulo: Loyola, 1995.

KUMAR, K. Da sociedade pós-industrial á sociedade pós-moderna. Rio de Janeiro: Jorge Zahar, 1997.

. A arte de formar-se. São Paulo: Loyola, 2001.

LIBANIO, J. B. A Lógica da cidade: o impacto sobre a fé e sob o impacto da fé. Loyola: São Paulo, 2001.

Paulo: Loyola, 2005.

Concílio Vaticano II. Em busca de uma primeira compreensão. São Desafios da Pós-Modernidade à Teologia Fundamental.

. Eu creio, nós cremos: tratado da fé. São Paulo: Loyola, 2000.

.Jovens em tempos de pós-modernidade: considerações socioculturais e pastorais. São Paulo: Loyola, 2004.

LIPOVETSKY G. A sociedade da Decepção. Entrevista coordenada por Bertand Richard. São Paulo: Manole, 2007.

El crepúsculo del deber. La ética indolora de los nuevos tiempos democráticos. Barcelona: Espanha: Editora Anagrama, 1994.

. La era del vacío. Barcelona, Anagrama, 1986.

LIPOVETSKY, G.; SERROY, J. A cultura-mundo: resposta a uma sociedade desorientada. São Paulo: Companhia das letras, 2011.

LYOTARD, J. F. O pós-moderno. RJ. Olympio Editora, introdução, viii, 1986.

Cátedra, 1987.

La condición postmoderna: informe sobre el saber. Madrid: 1987.

La postmodernidade explicada a los niños. Barcelona: Gedisa, . Moralidades posmodernas. Madrid: Tecnos, 1998.

MAFFESOLI, M. A transfiguração do político, a tribalização do mundo. Porto Alegre: Sulina, 2005.

Ronde: Paris, 2007.

Le réenchantement du monde. Une éthique pour temps. La Table

O tempo das tribos. $O$ declínio do individualismo nas sociedades de massa. 4. ed. Rio de Janeiro: Forense Universitária, 2006.

MARDONES, J. M. Adónde va la religión? Santander: Sal e Terrae, 1996.

. Análises de La sociedad y Fe Cristiana. Madrid: PPC, 1995. 
PPC, 2000.

En el umbral del mañana. El cristianismo del futuro. Madrid:

MARTELLI, S. A Religião na sociedade pós-moderna: entre a secularização e a dessecularização. São Paulo: Paulinas, 1995.

MARTINS, J. L. No espírito e na verdade - Introdução teológica à liturgia. Volume 1. Petrópolis: Vozes, 1996.

MARIZ, C. L. Catolicismo no Brasil contemporâneo: reavivamento e diversidade. In: TEIXEIRA, F.; MENEZES R. (orgs.). As religiões no Brasil: continuidades e rupturas. Petrópolis: Vozes, 2006.

MENEZES, D. H. L. CEBs: do Vaticano II a Aparecida. In: OROFINO. F, e alli. CEBs e os desafios do mundo contemporâneo. Iser Assessoria/ Paulus, 2012.

MIRANDA, M. F. A salvação de Jesus Cristo: a doutrina da graça. São Paulo: Loyola, 2004.

MIRANDA, M. F. Salvação ou Salvações? A salvação cristã num contexto interreligioso. In: Revista Eclesiástica Brasileira. Petrópolis: Vozes, v. 58, fasc. 229, janeiro/abril, 1998 (pp. 136-163).

MONTEIRO, P.; ALMEIDA, R. M. O campo religioso no limiar do século. Problemas e perspectivas. In: RATTNER, H. Brasil no limiar do século XXI. São Paulo: Fapesp/Edusp, 2003.

MORIN, E. Rumo ao abismo: ensaio sobre o destino da humanidade. Bertrand Brasil: Rio de Janeiro, 2011.

MORANO, D. Orar depois de Freud. São Paulo: Loyola, 2000.

OLIVEIRA, M. A. A crise da racionalidade Moderna: uma crise de esperança. In: Ética e racionalidade moderna. São Paulo: Loyola, 1999.

Cristianismo e construção da cidadania. In: Revista de Teologia e Ciências da Religião da Unicap. Recife, Ano VII, n. 7, 2008,

Pluralismo e Ética. In: OLIVEIRA, M. A. Ética e Práxis Histórica. São Paulo: Ática, 1995.

ORO, I. P. O fenômeno religioso: como entender. São Paulo: Paulinas, 2013.

PALÁCIO, C. O cristianismo na América latina: discernir o presente para preparar o futuro. In: Perspectiva Teológica. Belo Horizonte, v., 36, fasc. 99, maio/agosto 2004 (pp. 173-196).

Novos paradigmas ou fim de uma era teológica? In: FABRI, M (org). Teologia aberta ao futuro. São Paulo: Soter/Loyola, 1997.

QUEIRUGA, A. T. Creio em Deus Pai: o Deus de Jesus como afirmação plena do humano. $2^{\circ}$ ed. São Paulo: Paulus, 1993.

. Fin del cristanismo premoderno. Retos hacia um nuevo horizonte.

Santander: Sal Terrae, 2000.

Recuperar a criação: por uma religião humanizadora. 2. ed.

São Paulo: Paulus, 1999 (Col. Teologia hoje). 
Recuperar a salvação: por uma interpretação libertadora da experiência cristã. São Paulo: Paulus, 1999 (Col. Teologia hoje).

RAHNER, K. O desafio de ser cristão: textos espirituais. Petrópolis: Vozes, 1978. Posição do cristão no mundo moderno à luz da teologia. In: Missão e graça. Pastoral em pleno XX século. Vol I. Vozes: Petrópolis, 1964.

ROJAS, E. El hombre light: uma vida sin valores. Madrid. Temas de Hoy, 1992.

SANTOS. B. S. A crítica da razão indolente contra o desperdício da experiência. São Paulo: Cortez, 2007. A gramática do tempo. São Paulo: Cortez, 2006.

SANTOS, M. Por uma outra globalização. Rio de Janeiro: Record, 2001.

SOUZA, L. G; FERNANDES, S. R. A. (orgs.). Desafios do catolicismo na cidade: pesquisas em regiões metropolitanas brasileiras. CERIS-São Paulo: Paulus, 2002.

TEIXEIRA, F.; MENEZES R. (orgs.). As religiões no Brasil: continuidades e rupturas. Petrópolis: Vozes, 2006.

UNESCO: Educação, um tesouro a descobrir. Relatório Jacques Delors. São Paulo: CORTEZ- MEC-UNESCO, 1998.

WEBER, M. A ética protestante e o espírito do capitalismo. São Paulo: Pioneira, 1989.

VAZ, H, L. Raízes da modernidade ou fim de uma era teológica? In: Escritos de Filosofia VII. São Paulo: Loyola.

VALADIER, P. Catolicismo e sociedade moderna. São Paulo. Loyola, 1991.

VATTIMO. R. (org.). Il pensiero debole, Milão: Feltrinelli, 1992. O fim da Modernidade. São Paulo: Martins Fontes, 2002.

VELASCO, M. El fenômeno místico. Estudio comparado. Madri: Trotta, 1999. Ser Cristiano em um a cultura posmoderna. PPC: Madrid, 1996. . Neoliberalismo y religión. Estella: Verbo Divino, 1998.

VV. AA. Tutti responsabili nella Chiesa? Il ministero presbiterale in uma Chiesa tutta ministeriale. Turim, 1975.

ZULEHNER, P. M. Teologia Pastorale. V. 1: pastorale fondamentale. Brescia: Queriniana, 1992.

\section{DOCUMENTOS PONTIFÍCIOS}

BENTO XVI. Carta Encíclica Deus Caritas est: do Sumo Pontífice aos bispos, aos presbiteros e aos diáconos, às pessoas consagradas e a todos os fiéis leigos sobre o amor cristão. São Paulo: Loyola, 2006.

JOÃO PAULO II. Carta Encíclica Redemptoris Missio: sobre a validade permanente do mandato missionário. São Paulo: Paulinas, 1991. 
Paulinas, 1983.

Exortação Apostólica Catechesi Tradendae. 1979. São Paulo:

. Exortação Apostólica Christifideles Laici. Sobre a vocação e missão dos leigos na Igreja e no mundo. São Paulo: Paulinas, 1988.

Carta apostólica Novo millennio Ineunte. No início do novo milênio do Sumo Pontífice João Paulo II ao episcopado, ao clero e aos fiéis no termo do grande jubileu do ano 2000.

PAULO VI. Exortação Apostólica Evangelii Nuntiandi. A evangelização no Mundo Contemporâneo. São Paulo: Paulinas, 1977.

SAGRADA CONGREGAÇAO PARA O CLERO. Diretório Catequético Geral. 1971. $2^{a}$ ed. São Paulo: Paulinas, 1979.

Catequese. São Paulo: Paulinas, 1997.

Diretório Geral para a

\section{DOCUMENTOS CONCILIARES}

CONCILÍO VATICANO II. Decreto Ad Gentes sobre a Atividade Missionária da Igreja. Documento do Vaticano II, 1965, Petrópolis: Vozes, 1966.

Constituição Dogmática Dei Verbum sobre a Revelação

Divina. Documento do Vaticano II, 1965, Petrópolis: Vozes, 1966.

Constituição pastoral Gaudium et Spes sobre a Igreja no mundo de hoje. Documentos do Vaticano II, 1965. Petrópolis: Vozes, 1999.

. Constituição Sacrosanctum Concilium sobre a Sagrada Liturgia". In: Compêndio do Vaticano II. Constituições, Decretos, Declarações. Petrópolis, Vozes, 1997 (pp. 259-306).

Paulus, 1965.

Decreto Presbyterorum Ordinis. 4. ed. São Paulo: . Decreto Christus Dominus sobre o munus pastoral dos bispos na igreja. Petrópolis: Vozes, 1966.

. O apostolado dos leigos: Decreto Apostolicam Actuositatem. (Documentos Pontifícios, 161). 6.ed. Petrópolis; Vozes, 1969.

\section{MAGISTÉRIO LATINO-AMERICANO}

CELAM. A catequese na América Latina. Linhas gerais de orientação. Departamento de catequese (DECAT). São Paulo: Paulinas, 1986.

- Texto conclusivo da V Conferência Geral do Episcopado LatinoAmericano e do Caribe. São Paulo: Paulus, 2007.

. Manual de catequética. São Paulo: Paulus, 2007. 
II Conferência Geral do Episcopado Latino-americano. A Igreja na atual transformação da América Latina à Luz do Concílio. Conclusões de Medellín. São Paulo: Paulinas, 1968.

III Conferência Geral do Episcopado Latino-americano. Evangelização no presente e no futuro da América Latina. Conclusões de Puebla. São Paulo: Paulinas, 1979.

- IV Conferência Geral do Episcopado Latino-americano. Nova Evangelização, Promoção Humana, Cultura Cristã - Jesus Cristo, ontem, hoje e sempre. Documento de Santo Domingo. São Paulo: Loyola, 1993.

\section{IGREJA NO BRASIL}

ARQUIDIOCESE DO RIO DE JANEIRO. $11^{\circ}$ Plano de pastoral de conjunto. O Rio de Janeiro em missão. Arquidiocese do Rio de Janeiro 2012-2016. Editora Nossa Senhora da Paz: Rio de Janeiro, 2011.

CNBB. Catequese para um mundo em mudança: cada um ouvia na sua própria língua. São Paulo: Paulus, 1994.

Catequese renovada: orientações e conteúdo (Documentos da CNBB 26).

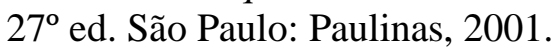

80).

. Com adultos, catequese adulta São Paulo: Paulus, 2001 (Estudos da CNBB

. Comunidade de comunidades: uma nova paróquia. Ed. CNBB, 2013 (Estudos da CNBB 104).

Diretório Nacional de Catequese. Texto aprovado pela $43^{\mathrm{a}}$ Assembléia Geral, em Itaici - Indaiatuba (SP), 9 a 17 de agosto de 2005. (Documentos da CNBB, n. 84), $2^{\text {a }}$ Ed. São Paulo: Paulinas, 2006.

. Diretrizes para a formação dos presbíteros na Igreja do Brasil (Documento da CNBB 93), Paulinas, São Paulo 2010; e outra referência universal, a Exortação Apostólica Pos-sinodal Pastores Dabo Vobis.

. Iniciação à Vida Cristã: um processo de inspiração catecumenal. Brasília: CNBB, 2009 (Estudos da CNBB 97).

. Missão e ministérios dos cristãos leigos: o serviço a vida e a esperança. 3.ed. São Paulo, 1998 (Estudos da CNBB 77).

. Ritual da Iniciação Cristã dos Adultos (Ritual romano renovado por decreto do Concílio Vaticano II, promulgado por autoridade do papa Paulo VI). 3. Ed. São Paulo, 1980.

Segunda Semana Brasileira de Catequese: Catequese com adultos: histórico, abertura, conteúdos, propostas e compromissos, documentos. (Estudos da CNBB, 84). São Paulo: Paulus, 2002.

Situação e vida dos seminaristas maiores no Brasil. (Estudos da CNBB, $\mathrm{n}$. 74) Paulus: São Paulo, 1995. 